UNIVERSIDADE DE SÃO PAULO

FACULDADE DE ODONTOLOGIA

\title{
AVALIAÇÃO DOS ARCOS DENTAIS E DAS ESTRUTURAS MIOFUNCIONAIS ORAIS, EM FUNÇÃO DO USO E TIPO DE CHUPETA, EM CRIANÇAS COM DENTIÇÃO DECÍDUA COMPLETA
}

CRISTINA GIOVANNETTI DEL CONTE ZARDETTO

Dissertação apresentada à Faculdade de Odontologia da Universidade de São Paulo, para obtenção do Título de Mestre, pelo curso de Pós-Graduação em Odontologia. Área de concentração em Odontopediatria. Orientadora:

Profa. Dra. Célia Regina Martins Delgado Rodrigues

São Paulo

2000 


\title{
AGRADECIMENTOS
}

\section{ESPECIAIS}

\begin{abstract}
A orientadora e amiga Célia Regina Martins Delgado Rodrigues, exemplo de persistência, "força" e dedicação, pela orientação segura e contínuo estímulo. Serei sempre grata pela confiança depositada em mim.
\end{abstract}

A RUY, MAMI, PICHO, TUCA, NONNA, JUREMA, FRANCISCO E MARIA, por cuidar com tanto carinho e dedicação do Marco, nos meus períodos de ausência. 


\section{AGRADECIMENTOS}

À todos que me apoiaram, ajudaram, estimularam e souberam compreender meus períodos de ausência.

'A Fabiane Stefani Mirón, pelo belo trabalho na avaliação das estruturas miofuncionais orais das crianças.

À Monique Saviero Bennedetto, pela amizade e ajuda na avaliação das crianças.

Ao Prof. Dr. Antônio Carlos Guedes-Pinto, pela confiança deposita em mim.

Profa. Dra. Márcia Pinto Alves Mayer, por ter me despertado para o fascínio da carreira acadêmica.

À Prof ${ }^{a}$. Dra. Maria Saleta Nahás Pires Corrêa, pelo estímulo e apoio constantes.

À Prof ${ }^{a}$. Dra. Climene Valentin, por ter me acolhido carinhosamente.

À Ana Claudia Durante Ramires-Romito, amiga e colega de Mestrado, pela ajuda e apoio oferecidos durante o curso.

À Renata de Oliveira Guaré, amiga e colega do Mestrado, pela sua vivacidade e alegria contagiante, força e determinação.

Às crianças, mães, professoras e diretoras que participaram deste estudo, sem as quais não teria sido possível sua realização.

À Vânia Martins Bueno de Oliveira Funaro, pela revisão bibliográfica e orientação sobre as normas para apresentação desta Dissertação.

À Marize Morais Paiva, pelos "socorros" imediatos.

À CAPES, pela bolsa de estudo concedida durante o curso de Mestrado. 


\section{SUMÁRIO}

p.

RESUMO

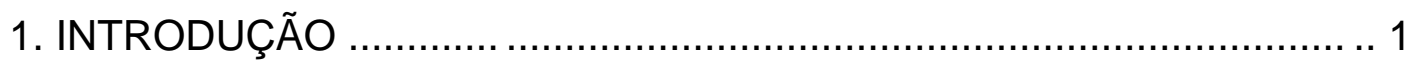

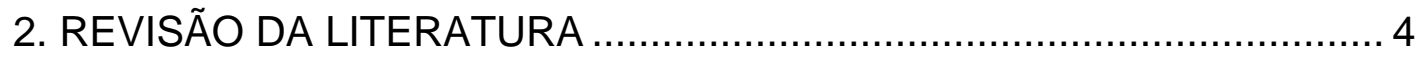

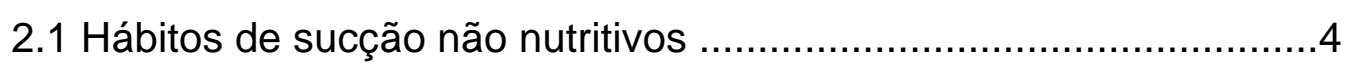

2.2 Estruturas miofuncionais orais e hábitos de sucção

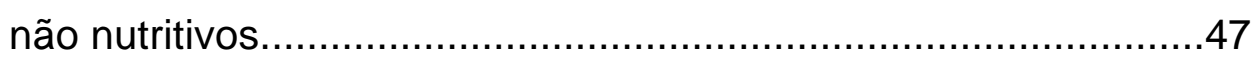

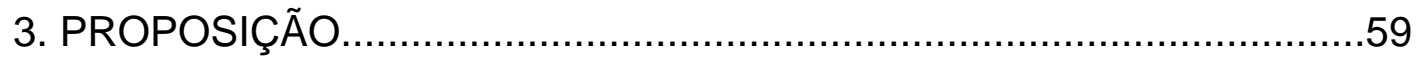

4. CASUÍSTICA-MATERIAL E MÉTODOS ......................................60

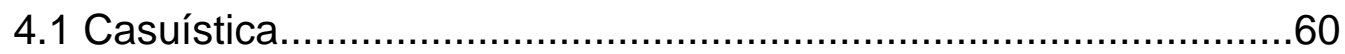

4.2 Material e Métodos ..........................................................62

4.3 Análise Estatística ......................................................68

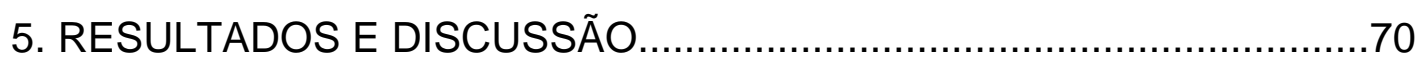

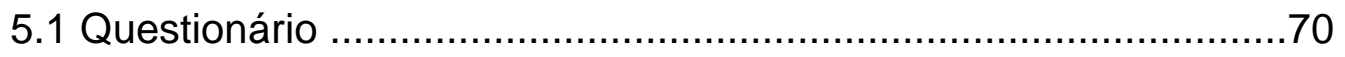

5.2 Avaliação dos arcos dentais ...........................................104

5.3 Avaliação das estruturas miofuncionais orais ...........................126

5.4 Considerações finais ..................................................... 137

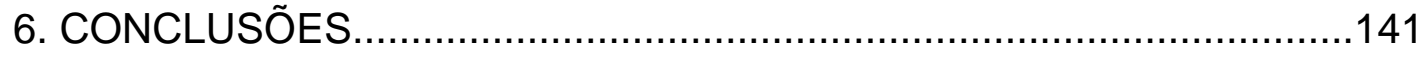

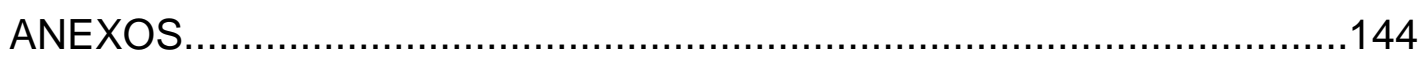

REFERÊNCIAS BIBLIOGRÁFICAS ............................................. 182

SUMMARY

APÊNDICES 


\section{LISTA DE FIGURAS}

Figura1 - Esquema dos tipos de chupetas anatômicas 61

Figura 2 - Esquema da chupeta convencional 62

Figura 3 - Distribuição das crianças segundo o sexo 72

Figura 4 - Distribuição da freqüência relativa do tipo de chupeta segundo o sexo .72

Figura 5 - Distribuição de freqüência relativa da variável "Idade que terminou o aleitamento materno exclusivo", em meses 80

Figura 6 - Distribuição de freqüência da relativa variável "Idade que cessou aleitamento materno", em meses 81

Figura 7 - Distribuição de freqüência relativa da variável "Inicio uso da mamadeira", em meses. .85

Figura 8 - Distribuição da freqüência relativa da variável "Continua usando mamadeira" 86

Figura 9 - Distribuição da freqüência relativa da variável "Quem introduziu a chupeta àcriança" 91

Figura 10 - Distribuição da freqüência relativa da variável "Idade de início da chupeta" .92 
Figura 11 - Distribuição da freqüência relativa da variável "Por que iniciou o uso de chupeta"

Figura 12 - Distribuição da freqüência relativa da variável "Relaciona uso de chupeta com que fatores?" 95

Figura 13 - Distribuição da freqüência relativa da variável "Momento do dia que criança usa chupeta" .96

Figura 14 - Distribuição da freqüência relativa da variável "Momento do dia que usa chupeta com o tipo de chupeta 96

Figura 15 - Distribuição da freqüência relativa da variável "Como suga" segundo o tipo de chupeta .98

Figura 16 - Distribuição da freqüência relativa das variáveis "Fica com mais de uma chupeta" e "Chupeta fica presa àroupa" 99

Figura 17 - Distribuição da freqüência relativa da variável "Número de chupetas do enxoval do bebê". 100

Figura 18 - Distribuição da freqüência relativa da variável "Relação canina lado direito" segundo o "Uso e tipo de chupeta" 106

Figura 19 - Distribuição da freqüência relativa da variável "relação canina lado esquerdo" segundo "Uso e tipo de chupeta" 107

Figura 20 - Distribuição da freqüência relativa da variável "Mordida cruzada posterior" segundo o "Uso e tipo de chupeta" 110

Figura 21 - Distribuição da freqüência relativa da variável "Sobremordida" segundo o "Uso e tipo de chupeta" 116

Figura 22 - Distribuição da freqüência relativa da variável "Mobilidade da bochecha" segundo o "Uso e tipo de chupeta" 127 
Figura 23 - Distribuição da freqüência relativa do formato do palato duro segundo o tipo e uso de chupeta" 129

Figura 24 - Distribuição da freqüência relativa da variável "Tonicidade da bochecha segundo o uso e tipo de chupeta 132 


\section{LISTA DE TABELAS}

TABELA 4.1 - Distribuição das freqüências da variável "Uso e tipo de chupeta" 61

TABELA 5.1 - Estatística descritiva da variável "Idade" (em meses) segundo a variável "Uso e tipo de chupeta" .71

TABELA 5.2 - Distribuição das freqüências da variável "Idade" (anos completos) segundo a variável "Uso e tipo de chupeta" .71

TABELA 5.3 - Distribuição das freqüências da variável "Renda familiar" (números de salários mínimos) segundo a variável "Escolaridade materna" .73

TABELA 5.4 - Testes de Independência (Qui-quadrado de Pearson) entre a variável "Usa chupeta" e as variáveis "Sexo", "Renda familiar", "Estudo da mãe", "Irmãos", "Término do aleitamento materno exclusiva", "Término do aleitamento materno", "Continua usando mamadeira", "Quantas chupetas no enxoval, "Orientação quanto àchupeta no curso", "Levou chupetas para a maternidade" .74

TABELA 5.5 - Distribuição das freqüências da variável "Uso e tipo de chupeta" segundo a variável "Estudo da mãe" 76 
TABELA 5.6 - Distribuição das freqüências da variável "Marca da chupeta" 78

TABELA 5.7 - Distribuição das freqüências da variável "Material da chupeta"

TABELA 5.8 - Distribuição das freqüências da variável "Usa chupeta" segundo a variável "Término do aleitamento materno exclusivo" .81

TABELA 5.9 - Distribuição das freqüências da variável "Usa chupeta" segundo a variável "Término da aleitamento materno" .82

TABELA 5.10 - Testes de Independência (Qui-quadrado de Pearson) entre as variáveis "Renda familiar" e "Grau de estudo da mãe" com o "Formato do bico da mamadeira" .86

TABELA 5.11 - Distribuição das freqüências da variável "Formato do bico da mamadeira" segundo a variável "Renda familiar" 87

TABELA 5.12 - Distribuição das freqüências da variável "Formato do bico da mamadeira utilizado" segundo a variável "Estudo da mãe" .87

TABELA 5.13 - Distribuição das freqüências da variável "Formato do bico da mamadeira utilizado" 88

TABELA 5.14 - Distribuição das freqüências da variável "Material do bico da mamadeira utilizado" .88

TABELA 5.15 - Distribuição das freqüências da variável "Marca do bico da mamadeira utilizado" .89

TABELA 5.16 - Distribuição das freqüências da variável "Usa chupeta" segundo a variável "Continua usando mamadeira" .89 
TABELA 5.17 - Estatística descritiva da variável "Há quanto tempo usa chupeta" segundo a variável "Uso e tipo de chupeta" 93

TABELA 5.18 - Distribuição das freqüências da variável "Usa chupeta" segundo a variável "Quantas chupetas no enxoval" 101

TABELA 5.19 - Distribuição das freqüências da variável "Levou chupetas para a maternidade" 102

TABELA 5.20 - Distribuição das freqüências da variável "Usou chupeta na maternidade" 103

TABELA 5.21 - Distribuição das freqüências da variável "Uso inadequado de chupeta pode causar dano" 103

TABELA 5.22 - Testes de Independência (Qui-quadrado de Pearson) entre as variáveis da avaliação dos arcos dentais e a variável "Uso e tipo de chupeta" 104

TABELA 5.23 - Intervalos de confiança para as diferenças entre as probabilidades de relação Classe I na variável "Relação canina - lado direito", com coeficiente de confiança global de $95 \%$ 107

TABELA 5.24 - Intervalos de confiança para as diferenças entre as probabilidades de relação Classe I na variável "Relação canina - lado esquerdo", com coeficiente de confiança global de $95 \%$ 108

TABELA 5.25 - Distribuição das freqüências da variável "Mordida cruzada posterior" segundo a variável "Uso e tipo de chupeta" 110

TABELA 5.26 - Testes de Independência (Qui-quadrado de Pearson) entre "Mordida cruzada posterior" e "Uso e tipo de chupeta", tomando as categorias de "Uso e tipo de chupeta" duas a duas 
TABELA 5.27 - Intervalos de confiança de Bonferroni para a variável "Sobressaliência (em milímetros)" com coeficiente de confiança global de $95 \%$

TABELA 5.28 - Distribuição das freqüências da variável "Sobressaliência normal" segundo a variável "Uso e tipo de chupeta" 113

TABELA 5.29 - Estatística descritiva da variável "Sobressaliência (em milímetros)" segundo a variável "Uso e tipo de chupeta" 114

TABELA 5.30 - Intervalos de confiança para as diferenças entre as probabilidades da varíavel "Mordida aberta anterior" com coeficiente de confiança global de $95 \%$ 116

TABELA 5.31 - Estatística descritiva da variável "Quanto de mordida aberta (em milímetros)" segundo a variável "Uso e tipo de chupeta" 118

TABELA 5.32 - Intervalos de confiança de Bonferroni para a variável "Distância intercanina do arco superior - Ponta da cúspide (em milímetros)" com coeficiente de confiança global de $95 \%$ 119

TABELA 5.33 - Estatística descritiva da variável "Distância intercanina do arco superior - Ponta da cúspide (em milímetros)" segundo a variável "Uso e tipo de chupeta" 119

TABELA 5.34 - Intervalos de confiança de Bonferroni para a variável "Distância intercanina do arco superior - Cervical (em milímetros)" com coeficiente de confiança global de $95 \%$. 120

TABELA 5.35 - Estatística descritiva da variável "Distância intercanina do arco superior - Cervical (em milímetros)" segundo a variável "Uso e tipo de chupeta" 120

TABELA 5.36 - Testes de Independência (Qui-quadrado de Pearson) entre as variáveis da avaliação dos arcos dentais e a variável "Como suga" 
TABELA 5.37 - Análise de Variância para a variável "Sobressaliência (milímetros)", com fator "Como suga"

TABELA 5.38 - Intervalos de confiança de Bonferroni para a variável "Sobressaliência (milímetros)" com coeficiente de confiança global de $95 \%$ 124

TABELA 5.39 - Testes de Independência (Qui-quadrado de Pearson) entre as variáveis da avaliação estruturas miofuncionais orais e a variável "Uso e tipo de chupeta" 126

TABELA 5.40 - Intervalos de confiança para as diferenças entre as probabilidades de Normal na variável "Bochecha - mobilidade", com coeficiente de confiança global de $95 \%$ .128

TABELA 5.41 - Intervalos de confiança para as diferenças entre as probabilidades de Normal na variável "Palato duro", com coeficiente de confiança global de $95 \%$ 130

TABELA 5.42 - Distribuição das freqüências da variável "Lábios - Aspecto" segundo a variável "Uso e tipo de chupeta" 133

TABELA 5.43 -Distribuição das freqüências da variável "Lábios - Tonicidade" segundo a variável "Uso e tipo de chupeta" .134

TABELA 5.44 - Testes de Independência (Qui-quadrado de Pearson) entre as variáveis da avaliação das estruturas miofuncionais orais e a variável "Como suga" 136 


\section{LISTA DE ABREVIATURAS E SÍMBOLOS}

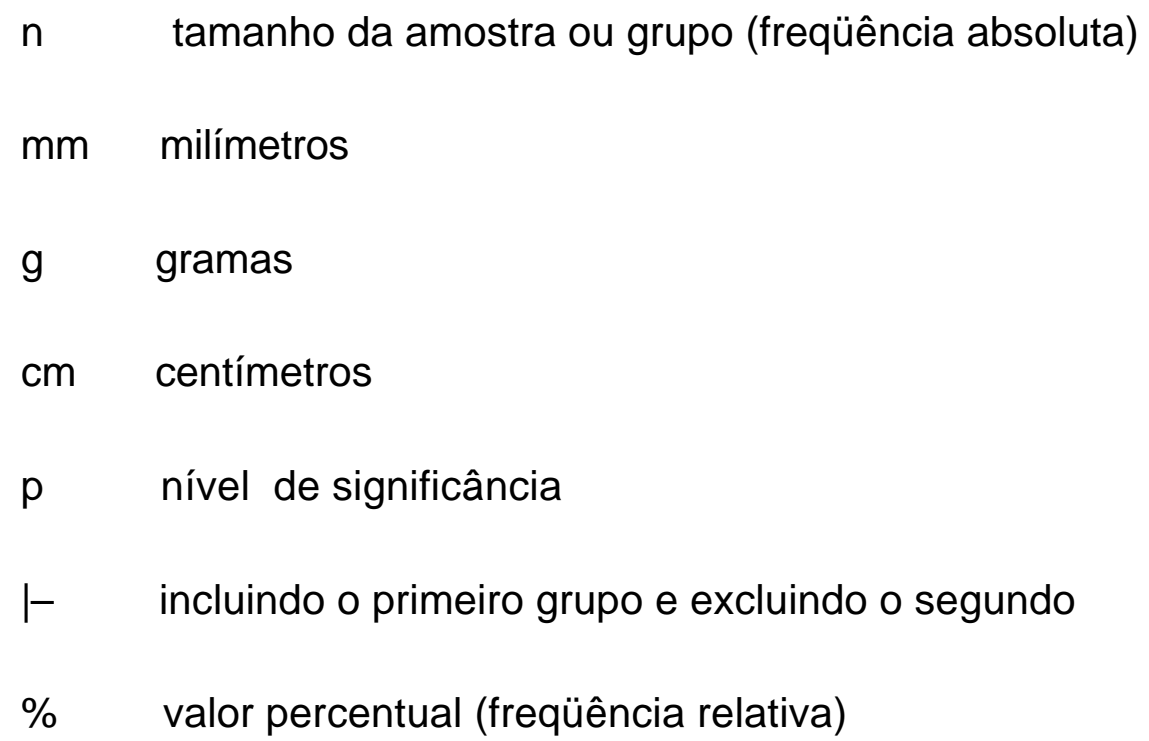




\section{RESUMO}

\section{AVALIAÇÃO DOS ARCOS DENTAIS E DAS ESTRUTURAS MIOFUNCIONAIS ORAIS, EM FUNÇÃO DO USO E TIPO DE CHUPETA, EM CRIANÇAS COM DENTIÇÃO DECÍDUA COMPLETA}

Neste estudo avaliou-se as características dos arcos dentais e das estruturas miofuncionais orais de 61 crianças na faixa etária de 36 a 60 meses que apresentavam hábito de sucção de chupeta ou não, e a relação entre o uso e tipo de chupeta com diversos aspectos comportamentais da mãe, grau de escolaridade materna e renda familiar. Estes últimos três aspectos foram avaliados por meio de questionário distribuído s̀ mães, e as características dos arco dentais e das estruturas miofuncionais orais por meio de exame clínico. As crianças foram dividas em três grupos conforme o uso e tipo de chupeta: 1. grupo que nunca sugou chupeta, 2. grupo que sugava somente a chupeta anatômica (ortodôntica) e, 3. grupo que sugava somente a chupeta convencional. Não foi encontrada associação estatisticamente significante entre o uso da chupeta e o sexo e número de irmãos da criança, renda familiar e grau de estudo formal da mãe. Verificouse que o período de aleitamento materno menor e o fato de ter tido uma ou 
mais chupetas já no enxoval do bebê, favoreceram o uso da chupeta. Não foi encontrada relação estatisticamente significante entre o tipo de arco dental, relação terminal dos segundos molares decíduos, linha média e espaço primata entre os três grupos avaliados. Notou-se que a relação canina Classe II foi significantemente maior nas crianças que sugavam chupeta do que naquelas que não tinham este hábito. Constatou-se que tanto a chupeta anatômica como a convencional, favoreceram o desenvolvimento da mordida aberta anterior e cruzada posterior. Não houve diferença estatisticamente significante entre as médias de mordida aberta anterior nas crianças que usavam chupeta convencional ou anatômica $(p=0,344)$. A prevalência da mordida cruzada posterior foi estatisticamente maior nas crianças que sugavam a chupeta convencional do que naquelas que sugavam a anatômica (ortodôntica) ou não tinham este hábito $(p=0,010)$. As distâncias intercaninas do arco superior foram significantemente menores nas crianças que sugavam chupeta do que naquelas sem este hábito. Já nas distâncias intercaninas do arco inferior, não houve diferença entre os três grupos. A dimensão da sobressaliência foi maior em ambos os grupos de chupeta quando comparados ao grupo sem hábito de sucção $(p=0,000)$. Em relação ao modo de sugar a chupeta, observou-se que a sobressaliência nas crianças que sugavam sempre a chupeta $(p=0,021)$, foi estatisticamente maior do que daquelas que sugavam às vezes. Das estruturas miofuncionais orais avaliadas, houve associação estatisticamente significante entre a mobilidade da bochecha $(p=0,022)$ e formato do palato duro $(p=0,042)$ com o uso e tipo de chupeta; 
sendo que as crianças que nunca sugaram chupeta, apresentaram uma prevalência maior de normalidade destas duas estruturas do que aquelas que sugavam chupeta. 


\section{INTRODUÇÃO}

O uso da chupeta ou "bicos" semelhantes ao do seio materno não é uma prática moderna. Segundo Gorelick (1955) existem registros da época de 100 anos antes de Cristo destes artifícios, feitos em argila, junto a sepulturas de crianças romanas. Acredita-se que a chupeta atual tenha sido precedida pelo "bico de açúcar", apetrechos feitos de retalhos de fazendas ou de "chamois" recheados de migalhas de pão e açúcar e amarrados para mimitizar o mamilo materno. Estes eram introduzidos na boca da criança quando ela chorava.

As práticas descritas mostram as fortes relações estabelecidas entre a criança e a necessidade de sugar, assim como o uso de artifícios para acalmar o choro da criança. Isto pode explicar os motivos pelos quais, atualmente, o uso da chupeta por crianças é visto como natural e comum na sociedade e a grande maioria das mães acredita que a chupeta seja uma parte importante no enxoval do bebê.

Autores preocupados com possíveis danos que o hábito de sucção de chupeta poderia trazer aos arcos dentais investigaram esta relação. Inúmeros são os relatos de maloclusões associadas aos hábitos bucais nocivos, dentre eles o uso da chupeta (Larsson, 1972; Bacchi, 1973; Larsson, 1975; Larsson, 1986; Peters et al., 1986; Hannuksela \& 
Väänänen, 1987; Kuijpers-Jagtman, 1989; Silva Filho et al., 1991; Adair et al., 1992; Paunio et al., 1993; Adair et al., 1995; Chan et al., 1996; SerraNegra et al., 1997; Farsi et al., 1997; Robles et al., 1999; Tomita et al., 2000).

Foram também descritos na literatura as alterações nas estruturas miofuncionais orais provocadas por hábitos de sucção não nutritivos (Bowden, 1966b; Dadalto, 1989; Black et al., 1990; Gomes et al., 1993; Soares \& Totti, 1996; Adair, 1996; Carvalho, 1997 ; Camargo et al., 1998).

Existem no mercado já há algum tempo, as chupetas denominadas de ortodônticas ou anatômicas com características específicas e diferentes das chupetas convencionais.

Embora a chupeta convencional seja sempre contra-indicada pelos profissionais, o uso da chupeta anatômica (ortodôntica) poderia ser indicado, em algumas situações. Isto poderia ocorrer, por exemplo, para substituir a sucção de dedo (Zadik et al., 1977; Moyers, 1988) ou o uso da chupeta convencional (Gomes et al., 1993), e ainda para agir como "exercitador" de sucção na reorganização neurofuncional (Padovan, 1997). Camargo et al. (1998) acreditam que a chupeta deva ser utilizada apenas como aparelho para realizar exercícios de sucção, estimulando os movimentos musculares e beneficiando o crescimento e desenvolvimento das bases ósseas. Portanto, a chupeta não deve ser utilizada para acalmar o choro da criança devido a outros motivos como cólica, susto, desconforto, solidão ou consolo. 
É expressivo ainda o número de autores que acreditam que se o hábito for interrompido até os 2 - 3 anos de idade, não ocorrerão danos à oclusão (Moffatt, 1963; Larsson, 1972; Bacchi, 1973; Modéer et al., 1982; Kuijpers-Jagtman, 1989; Soares \& Totti ,1996; Tomita et al., 2000).

Assim, em função do número reduzido de trabalhos comparando o uso das chupetas anatômicas (ortodônticas) ou das convencionais, parece-nos interessante avaliar as repercussões de sua utilização nos arcos dentais e estruturas miofuncionais orais. 


\section{REVISÃO DA LITERATURA}

Tendo como objetivo verificar as características dos arcos dentais e das estruturas miofuncionais orais associadas ao hábito de sucção não nutritivo da chupeta, optou-se por abordar separadamente os assuntos para melhor compreensão do texto.

\subsection{Hábitos de sucção não nutritivos}

Desde 1931, Lewis já mencionava a influência dos hábitos sobre a dentição decídua. $\mathrm{O}$ autor primeiramente discorreu sobre o significado da palavra hábito. Ele relatou que esta palavra estava sendo utilizada em seu sentido geral com o intuito de descrever um mau hábito. Porém, deve-se lembrar que hábito é a tendência de comportar-se de uma maneira fixa sob certas circunstâncias. O hábito representa a cristalização de uma preferência de responder a uma determinada situação. Os maus hábitos podem ser danosos enquanto os bons hábitos benéficos.

Gorelick (1955) descreveu a história da chupeta. O autor relatou que a primeira patente de bico de borracha semelhante a chupeta atual de 
que se tem conhecimento é de agosto de 1845. Porém, há registros de bicos da época de 100 anos A.C. Estes foram encontrados junto àsepultura de crianças romanas, tinham formato imitando o seio materno e eram feitos em argila. Mais tarde, os bicos foram sendo confeccionados com outros materiais como prata, marfim, marfim descalcificado e até de mamilos (bico do seio) de bezerros recheados com esponja. A chupeta atual, provavelmente, foi precedida pelo que era chamado de bico de açúcar ou "trapo" de açúcar. Estes apetrechos eram feitos de retalhos de tecidos, trapos ou chamois nos quais se colocava migalha de pão e açúcar e amarrava-se de tal forma a se assemelhar ao mamilo materno. Quando a criança chorava, este era introduzido em sua boca. Mencionou também que, em 1802, um autor inglês, criticava esta prática e alertava para a falta de higiene, recomendando que os alimentos a serem colocados dentro do saquinho fossem frescos e que o pano fosse lavado. O uso de chupetas não era nem recomendado nem banido nos livros de medicina e odontologia, até que, em 1864, um autor associou o uso de chupeta com maloclusões, diarréia, hidrocefalia e até morte.

Em 1963, foi publicado um artigo baseado no discurso de Moffatt sobre hábitos bucais e suas relações com maloclusão realizado no Congresso Odontológico de 1960. O autor ressaltou que alterações histológicas ocorrem quando a criança mantém algum hábito de sucção como o dedo ou lábio, da mesma maneira quando da utilização de forças ortodônticas leves e lentas. Quando o hábito se mantém por algum período de tempo, o osso envolvendo o dente no lado oposto onde a força é exercida 
é lentamente reabsorvido. Caso o hábito persista, o dente é mantido nesta nova posição pelo novo osso que se formará.

Em estudo sobre a etiologia das maloclusões dentárias, Oliveira Fernandes (1964) comentou que o clínico fica impotente para controlar ou evitar fatores de origem hereditária ou congênita, porém pode atuar sobre os fatores adquiridos como por exemplo, os hábitos viciosos. Estes são destaques como fatores etiológicos das maloclusões. O hábito de chupar dedo ou chupeta promove uma inclinação para vestibular dos incisivos superiores e para lingual nos inferiores. A sucção de dedo é mais perniciosa que a de chupeta. Além disso, nota-se o fato do primeiro hábito prolongar-se por períodos superiores `aqueles encontrados em crianças que usam a chupeta. Tais hábitos devem ser controlados o mais precocemente possível, possibilitando a autocorreção.

Bowden (1966b) publicou um estudo longitudinal sobre os efeitos da sucção digital e da chupeta em crianças entre 3 e 8 anos de idade. 0 autor realizou algumas medidas tais como: distância intercanina e intermolar dos arcos superior e inferior, distância entre bordos incisais, sobremordida e sobressaliência. Neste estudo, todas as crianças cessaram o hábito de sucção de chupeta aos 30 meses de idade. O estudo mostrou que a sobressaliência estava aumentada nas crianças que utilizaram chupeta; assim como a sobremordida, a qual permaneceu inalterada até aproximadamente 5 anos após cessar o uso da chupeta. Até a faixa etária dos 6 anos, a distância intercanina dos arcos superior e inferior foi menor nas crianças que tiveram o hábito da chupeta do que naquelas que nunca o 
tiveram. O hábito de sucção de chupeta como o de dedo, teve efeito temporário na sobressaliência. Foi observado que esta melhora após o término do hábito, assim como foi demonstrado que o efeito da chupeta na sobremordida perdura por aproximadamente 3 anos após o término do hábito.

O mesmo autor (Bowden, 1966a), em continuação ao estudo anterior, encontrou que a mordida aberta anterior foi mais prevalente nas crianças com algum hábito de sucção; porém quanto `a mordida cruzada posterior, não houve diferença estatisticamente significante entre as crianças sem hábito de sucção ou aquelas que já o tiveram. Nas crianças que chuparam chupeta, houve uma diminuição temporária das distâncias intermolar dos arcos inferior e superior. O autor não observou mudança na relação canina e dos segundos molares decíduos em nenhum dos grupos estudados; como também não constatou diferença estatisticamente significante quanto a estas características nos diferentes grupos.

Em 1967, Popovich avaliou a prevalência de hábitos de sucção e sua relação com a maloclusão em crianças nas diversas faixas etária $(3,6$, 8, 10 e 12 anos). O autor verificou que a prevalência de hábitos de sucção diminui com a idade e que aos três anos de idade, 41,8\% ainda mantinha o hábito de sucção contra 43,2\% que tinha cessado. As crianças que cessaram com hábito de sucção antes dos 6 anos de idade apresentaram prevalência de maloclusões semelhantes àquelas que nunca tiveram nenhum tipo de hábito de sucção. 
Em 1971, Larsson estudou a prevalência de sucção de dedo e chupeta realizado com 920 crianças com nove anos de idade. Do total de 920 crianças examinadas, 662 tiveram história de hábito sucção, dos quais 113 tinham o hábito na época deste estudo (sendo um sugador de chupeta e o restante sugadores de dedo). A chupeta foi utilizada no primeiro ano de vida por $44,8 \%$ das crianças. Das crianças que tiveram ou tinham até aquele momento o hábito de sucção de chupeta, $46.2 \%$ eram meninas e 53.8\% meninos; das crianças que nunca tiveram nenhum hábito de sucção, 45.9\% eram meninas e $54.1 \%$ eram meninos. Do total de 412 crianças que utilizaram a chupeta, 351 cessaram o hábito antes dos quatro anos de idade e aos seis anos de idade, apenas 11 ainda mantinham este hábito de sucção.

Em continuação ao estudo anterior, Larsson (1972) analisou os efeitos dos hábitos de sucção de chupeta e dedo no crescimento facial e oclusão em crianças de nove anos de idade. Foram verificadas variáveis dentais e esqueléticas por meio do estudo em modelos de gesso e radiografias cefalométricas laterais. O grupo que sugava o dedo, continuou com o hábito até o momento do estudo. Das crianças que tinham o hábito de chupar chupeta, uma tinha cessado hábito até os 2 ou 3 anos de idade e outra mantive o hábito até os 4 anos ou mais. $\mathrm{O}$ autor encontrou diferença no grau de protrusão dos incisivos, distância entre borda incisal dos incisivos superiores com o ponto NGnL e entre os ângulos NSL e NL. Estes efeitos foram maiores nas crianças que mantiveram o hábito de sucção até os 4 anos de idade ou mais. Nas diversas variáveis estudadas, o autor constatou 
que os valores para as crianças que chuparam chupeta estavam entre aqueles apresentados pelo grupo controle e grupo dos sugadores de dedo. Os efeitos do hábito de sucção de chupeta, nas crianças que cessaram este hábito aos 2 ou 3 anos de idade, sobre a oclusão foi muito pequeno. Porém, estas alterações foram maiores no grupo com hábito prolongado de sucção de chupeta. Por outro lado, o autor acreditava que as alterações dentais que pareciam ser alarmantes em idade precoce nas crianças, apresentavam uma tendência a autocorreção quando o hábito é cessado.

Bacchi (1973) definiu hábito da seguinte maneira: “... comportamento ou conjunto de atitudes assumidos por um indivíduo que, após aprendê-los, torna-se capaz de repeti-los sem esforço consciente, apresentando gradativo aperfeiçoamento àmedida que decorrem o tempo e o número de práticas". Em vasta revisão de literatura sobre hábitos bucais e outros comportamentos considerados nocivos à oclusão dentária, o pesquisador verificou que os efeitos dos hábitos se tornam mais pronunciados quanto mais intensos, prolongados e repetitivos eles se apresentam. O autor também relatou que sob o ponto de vista ortodôntico, o profissional deveria prestar atenção quando estes hábitos estivessem presentes acima dos três anos de idade. Isto porque a literatura mostra que hábitos existentes antes dos três anos de idade, geralmente sofrem correção espontânea.

Sim \& Finn (1973) descreveram que o hábito bucal torna-se compulsivo quando a criança repete a ação nos momentos em que sua 
segurança é ameaçada. Desta maneira, a criança utilizaria o hábito bucal como válvula de escape quando a pressão emocional está em excesso.

Na Finlândia, Myllärniemi (1973) investigou a prevalência de hábito de sucção de dedo e chupeta em crianças entre 0 e 7 anos de idade. Nos centros de saúde da cidade onde foi realizado o levantamento, o uso da chupeta era aceito e muitas vezes recomendado quando a criança apresentava necessidade de sucção. O autor verificou que no primeiro ano de vida, 65\% das crianças apresentavam hábito de sucção de chupeta e que este diminuía com o aumento da idade, sendo que aos 5 anos, praticamente todas as crianças cessaram seu uso. Os hábitos de sucção foram mais comuns nas meninas do que nos meninos. $O$ autor ainda mencionou que é melhor sugar a chupeta do que o dedo, pois os efeitos deletérios deste último são piores para o arco dental do que o uso da chupeta; e, que em alguns casos, o uso da chupeta pode até prevenir o hábito de sucção de dedo.

Em 1974, Rutrick corrigiu, em criança de tenra idade, a mordida cruzada posterior e diminuiu a mordida aberta anterior, decorrente do hábito de sucção de chupeta tradicional (bulbo longo e arredondado) utilizando a chupeta ortodôntica NUK ${ }^{\mathrm{TM}}$ Secondary Exerciser durante 4 meses. Houve um aumento na largura na região posterior do arco. Como o bulbo desta última chupeta é grande e amplo, quando a língua e força de sucção são aplicados sobre ele, a chupeta se torna um "aparelho expansor" nos arcos dentais em desenvolvimento. 
Ravn (1974) investigou a prevalência de hábitos de sucção de dedo e chupeta em crianças de três anos de idade da cidade de Copenhague. O autor encontrou que $85 \%$ das crianças investigadas apresentavam ou tinham história de hábito de sucção; sendo que $47.1 \%$ apresentavam o hábito de sucção de chupeta aos três anos de idade. Foi verificado também que os meninos terminavam o hábito de sucção antes que as meninas e que o tipo de aleitamento, não teve influência nos hábitos de sucção.

Adimari (1975) estudou hábitos bucais, verificando a importância deles como fatores determinantes das maloclusões em 224 pacientes com idades entre 6 e 25 anos. Examinou também a deglutição, tipo de face e presença ou não de obstrução das vias aéreas superiores. Foi constatado que um grande número de pacientes (35 e 38) que apresentava hábito de sucção e onicofagia tinha concomitantemente hábito de deglutição atípica, respectivamente. A maioria das crianças com hábito de sucção apresentava maloclusão Classe II, Divisão $1^{\circ}$ e sobremordida profunda. A autora concluiu com base na literatura investigada, que os maus hábitos não deveriam ser aceitos como determinantes de maloclusões no período que antecede a erupção dos incisivos permanentes, e que praticamente a totalidade dos autores por ela consultados, concordavam que a sucção anormal é fator determinante de maloclusão quando realizada por tempo prolongado.Nos comentários finais deste trabalho, a autora caracterizou a sucção como "impulso natural caraterístico de todo mamífero" e descreveu sucção como um ato com fins nutritivos, que apresenta paralelamente satisfação psíquico- 
emocional. Ao receber o aleitamento materno, o recém-nascido deve satisfazer sua necessidade nutricional em equilíbrio com o prazer de realizar a sucção. Ao utilizar a mamadeira, a criança atinge a satisfação de plenitude alimentar, mas fica insatisfeita sua exigência emocional. Assim, a sucção não nutritiva é adotada para satisfazer as necessidades psico-emocionais da criança, através da sucção de polegar ou chupeta

Larsson (1975) fez um estudo bastante amplo sobre os hábitos de sucção, analisando 4.050 crianças suecas de 4 anos de idade. Observou que $18,9 \%$ das crianças eram sugadoras de dedo, $20,9 \%$ de chupeta e 24,3\% não apresentavam nenhum tipo de hábito de sucção; porém, de todas as crianças, $50 \%$ utilizaram chupeta em algum período. Dentre as crianças que sugavam a chupeta, $53,5 \%$ eram meninas e $46,5 \%$ meninos. $O$ autor mencionou que este estudo mostra uma redução do número dos sugadores de dedo, em função do aumento do número de crianças que sugam chupeta. Foi encontrada uma correlação altamente significante entre o aleitamento materno e hábito de sugar chupeta. Das crianças que mantiveram o hábito de sugar a chupeta até os 4 anos de idade, 97\% nunca não tinham recebido aleitamento materno ou o foram por menos que 6 meses de idade, enquanto que apenas 3,0\% foram aleitadas pelas mães por mais que seis meses de vida. Na Suécia, as crianças não receberam aleitamento materno por longos períodos, e muitas delas nem recebem aleitamento materno. O lactente recebe sua alimentação através de suplementos e fórmulas. Nestes casos, o instinto de sucção do recém-nascido é provavelmente adaptado para garantir o consumo de nutrientes em condições menos favoráveis. Portanto, 
o instinto de sucção não é plenamente satisfeito, predispondo a criança a desenvolver algum hábito de sucção. Assim, hábito nocivo de sucção tornase uma maneira de canalizar o instinto de sucção infantil em excesso. Este instinto desaparece nos primeiros anos de vida por que o seu objetivo de assegurar a aquisição de alimento não existe mais. $\mathrm{O}$ autor afirmou que é mais fácil romper hábito de sucção de chupeta do que o digital, porque a chupeta é um artifício que os pais podem jogar fora. A maioria das crianças que chupava chupeta, cessou o hábito aos 3 ou 4 anos de idade, enquanto as que chupavam dedo o fizeram mais tarde, aos 7 ou 8 anos de idade. As crianças que continuavam com estes hábitos nocivos de sucção após estas idades, provavelmente não foram suficientemente motivadas a parar ou apresentavam uma fixação não normal do comportamento oral. Das crianças que chuparam dedo precocemente, $84 \%$ mantiveram o hábito até os 4 anos de idade e das que sugavam chupeta, 37\% o mantiveram até esta idade.

O autor (Larsson, 1975) destacou que fatores externos podem determinar fortemente o desenvolvimento de algum tipo de hábito de sucção. O hábito de sucção da chupeta parecer não ser tão aceito nas famílias com maior nível educacional. Neste estudo, também foi avaliada a ansiedade das crianças. No grupo de crianças que manteve o hábito de sucção de chupeta até os 4 anos de idade, foi encontrado o maior número de crianças com ansiedade não normal. Outro fator verificado foi 0 desenvolvimento psico-físico da criança. Dentre as crianças que chupavam chupeta até os 4 anos de idade, houve o maior número de crianças que apresentavam alguma manifestação não normal do desenvolvimento 
(quando considerando se a criança se vestia e se calçava sozinha, urinava na cama e em que tipo de brincadeiras ela se engajava). Também foi ressaltado que as criança que usam chupeta articulam mais dificuldade do que as outras crianças da mesma idade e que não apresentavam este hábito. Um dos fatores responsáveis por isso, é a obstrução quando a chupeta está na boca, e a mordida aberta anterior. As crianças que apresentavam o hábito de sucção de chupeta estavam mais predispostas a apresentar quadros de otite; isto pode ocorrer por que ao sugar a chupeta, a criança engole mais vezes, e se ela estiver com o nariz obstruído ou tampado, uma pressão negativa é criada na nasofaringe, o que é muito determinante para estabelecimento da otite.

Ainda no mesmo estudo (Larsson, 1975), foi observado das crianças que sugaram a chupeta até os 4 anos de idade, $77,4 \%$ apresentavam uma oclusão normal e 21,1\% maloclusão Classe II. Daquelas que não tiveram nenhum hábito nocivo de sucção, 93\% apresentavam somente oclusão normal e somente 4\%, maloclusão Classe II. Com relação a oclusão no sentido vertical, das crianças que continuaram a sugar chupeta até os 4 anos de idade, $72,4 \%$ tinham mordida aberta anterior, contra $27,7 \%$ daquelas que chupavam dedo, e 2,5\% das crianças que nunca tiveram hábito de sucção não nutritiva. Dentre as crianças que cessaram o hábito de sugar a chupeta em idade inferior aos 4 anos, 15,1\% tinha mordida aberta anterior. Foi observada mordida cruzada posterior unilateral em 2,6\% das crianças que nunca tiveram hábito de sucção, em 10,9\% das que haviam 
usado chupeta até antes dos 4 anos, 13,2 \% das que ainda usavam chupeta aos 4 anos e em 7\% das crianças sugadoras de dedo.

Ravn (1976) investigou a relação canina e relação terminal dos segundos molares decíduos em modelos de gesso de 310 crianças de três anos de idade da cidade de Copenhague e correlacionou com hábitos de sucção das crianças. A maior proporção de relação canina Classe I foi verificada nas crianças sem nenhum hábito de sucção; por outro lado, aquelas que ainda mantiveram o hábito de sucção de chupeta até os três anos de idade, a porcentagem de relação canina Classe I foi a menor. A relação canina Classe II foi mais freqüente nas crianças que mantinham o hábito de sucção de chupeta do que naquelas que sugavam o dedo ou tinham cessado o hábito de sucção até os três anos de vida. A relação terminal dos segundos molares decíduos não apresentou diferença significante entre os diversos grupos de crianças com hábito de sucção de chupeta. O autor verificou que a mordida aberta anterior predominava naquelas crianças que persistiram com o hábito de sucção de chupeta ou polegar, sendo que esta alteração estava relacionada à duração do hábito. O grau ou severidade da mordida aberta anterior foi maior nas crianças que sugavam chupeta do que naquelas que sugavam dedo. Nas crianças que mantiveram o hábito de sucção de chupeta até os três anos de idade, houve um aumento entre 4-6 mm na sobressaliência. A sobressaliência foi mais freqüente naquelas que sugavam chupeta do que naqueles que sugavam o dedo. 
No ano seguinte, Zadik et al. (1977) conduziram um estudo com o objetivo de verificar a prevalência de hábito de sucção de dedo ou chupeta em crianças na faixa etária de 0 à 7 anos e relacionaram `a fatores como idade, sexo e duração do aleitamento materna nestas crianças. Os autores constataram que a prevalência dos hábitos de sucção digital ou de chupeta diminuía com a idade e que não houve correlação entre o tempo de aleitamento materno e o hábito de sucção não nutritivo. A porcentagem de crianças que eram filhos únicos e que apresentaram algum hábito de sucção foi grande (95\%), sendo que $85 \%$ correspondia ao uso de chupeta e $10 \%$ `a sucção de dedo. Os autores concluíram que oferecer chupeta à criança pode ser de grande valia, pois poderia prevenir o hábito de chupar o dedo, que provoca danos maiores àoclusão.

Moreira (1978) analisou a influência entre aleitamento e relação incisal, tipo de arco segundo Baume e prevalência de alguns hábitos em crianças na faixa etária de 3 a 6 anos. A autora observou que nas crianças que receberam exclusivamente o aleitamento materno (natural), a prevalência de hábitos nocivos foi de $56,52 \%$ contra $86,36 \%$ daquelas que receberam aleitamento artificial exclusivo e $85,7 \%$ aleitamento misto.

Margolis (1980) corrigiu mordida aberta anterior em paciente de 2 anos e meio de idade que tinha hábito de sugar chupeta convencional (bulbo longo e arredondado) por meio do uso da chupeta ortodôntica da marca $\mathrm{NUK}^{\mathrm{TM}}$. O autor relatou que as chupetas convencionais não permitem uma harmonia entre os músculos faciais e os lábios, promovendo mordida aberta anterior, respiração bucal e interposição de língua. Todas estas alterações 
levam a um estreitamento do arco superior, protrusão dos incisivos superiores e retrusão dos inferiores.

Em revisão de literatura sobre a relação entre hábitos orais e aleitamento materno ou artificial, Finocchi (1982) encontrou que o uso de bicos de mamadeiras longos e em forma de bulbo foi um fator importante para o desenvolvimento da interposição de língua. Os autores que mantém esta teoria acreditavam também que as crianças que recebem aleitamento materno apresentam probabilidade menor em desenvolver interposição lingual ou hábitos de sucção.

Em 1982, Modéer et al. investigaram a relação entre hábitos de sucção e mordida cruzada posterior em crianças suecas de 4 anos de idade. Os pais responderam a um questionário sobre os hábitos de sucção da criança e as crianças foram examinadas por dois autores. A maioria das crianças iniciou o hábito de sucção chupeta e/ou dedo no primeiro mês de vida, enquanto apenas $2 \%$ o fez aos dois anos de idade. Os autores encontraram que $54 \%$ das crianças tinham usado chupeta na maternidade. Os hábitos de sucção parecem ser mais freqüentes no primeiro ano de vida. Foi constatado também que aos 4 anos de idade, $48 \%$ das crianças ainda mantinham algum tipo de hábito de sucção e que $78 \%$ destas crianças usavam chupeta. A intensidade de sucção de chupeta encontrada foi de 3,7 horas por dia. A mordida cruzada posterior foi observada somente nas crianças com algum hábito de sucção passado ou presente até o momento do estudo. Das alterações investigadas, a mais freqüente foi a mordida cruzada posterior unilateral (15\%), e a menos freqüente foi a bilateral (2\%). 
A mordida cruzada posterior unilateral teve relação positiva com a intensidade do hábito de sucção, ou seja, quanto mais horas por dia era utilizada a chupeta, maior a prevalência desta alteração. Mordida cruzada unilateral posterior foi mais freqüente nas crianças que chupavam chupeta (19\%) do que naquelas que sugavam o dedo (11\%). As crianças do grupo controle (sem hábito) não apresentavam nenhum tipo de mordida cruzada posterior ou relação de topo a topo posterior. Os autores também encontraram que as discrepâncias transversais dos arcos dentais aumentavam grandemente quando o hábito de sucção persistiu após os dois anos de idade. Os autores acreditavam que a faixa etária dos dois aos três anos de idade é crítica, porque é o período de desenvolvimento da oclusão e aparentemente o mais sensível para a instabilidade da musculatura oro-facial. Portanto, concluíram que os hábitos de sucção devem cessar aos 2 anos de idade, para reduzir o risco de desenvolver mordida cruzada posterior unilateral na dentição decídua.

Larsson (1983) verificou a prevalência de mordida cruzada posterior em crianças com hábito prolongado de sucção de chupeta ou dedo, ou seja, aquele mantido após a erupção do primeiro molar permanente. A mordida cruzada posterior foi constatada em $16 \%$ das crianças com hábito de sucção de chupeta, contra $13.5 \%$ daquelas que chupavam o dedo. Segundo o autor, estes valores estão entre aqueles considerados normais para esta faixa etária. O pesquisador relatou ter observado diversos casos em que a criança com hábito de sucção de chupeta apresentava mordida cruzada posterior na dentição decídua, sem afetar posteriormente a região 
dos molares permanentes. $O$ fato da mordida cruzada posterior ter sido observado na dentição decídua de crianças de pouca idade e não na dentição permanente, mesmo quando o hábito de sucção continuou, pode ser explicado por alguns fatores. Um deles é que o efeito tanto da chupeta quanto do dedo é limitado a região anterior do palato, porque tanto o dedo quanto a chupeta, não são colocados muito "para posterior". O bico da chupeta tem aproximadamente 25 milímetros de comprimento, o que preenche completamente a cavidade bucal de criança de pouca idade. A distância entre os incisivos e a fossa mesial do primeiro molar permanente é de 30 a $35 \mathrm{~mm}$, portanto devido a esta distância é muito provável que o hábito de sucção não afete os molares permanentes. Outro fator é que o hábito de sugar a chupeta, geralmente é interrompido na fase de erupção dos pré-molares. Mesmo naquelas crianças que mantiveram o hábito de sucção de dedo até este período, não foi observado um aumento na prevalência de mordida cruzada posterior na região de pré-molares.

Larsson (1985) estudou a prevalência e etiologia de hábitos prolongados de sucção não nutritivos em crianças de 9 anos de idade da Suécia e comparou com os resultados de um estudo similar realizado 14 anos antes. Constatou que houve uma diminuição na freqüência das crianças que realizavam sucção de dedo aos nove anos de $14 \%$ para $6 \%$. Neste mesmo período, o número de crianças que não iniciaram o hábito de sucção de dedo ou chupeta também diminuiu de $32 \%$ para $10 \%$. Isto é explicado pelo aumento no número de crianças que chuparam chupeta e uma diminuição daquelas que sugavam dedo. Todas as crianças que 
sugavam chupeta tinham parado com o hábito aos nove anos de idade. $\mathrm{O}$ autor mencionou que as crianças do ocidente apresentam uma necessidade de sucção maior e esta pode ser canalizada no desenvolvimento de um hábito de sucção. O investigador afirmou que se for oferecida uma chupeta à criança que apresenta necessidade de sucção, provavelmente ela adquirirá o hábito de sucção de chupeta; nos casos em que não é oferecida uma chupeta para saciar esta necessidade de sucção, a criança desenvolverá o hábito de sução de dedo. A maioria das crianças cessa o hábito de sucção da chupeta por volta dos 5 ou 6 anos de idade; enquanto que as que sugam o dedo, prolongam este hábito até os 6 ou 7 anos de idade ou mais.

No mesmo ano, Larsson \& Dahlin (1985) publicaram um estudo sobre a prevalência e etiologia dos hábitos de sucção de chupeta e dedo. Três grupos faziam parte dos estudo: 1. crânios com dentição decídua intacta do período entre 1000 e 1500 A.C., 2. crianças de pouca idade do Zimbabwe e 3. crianças de pouca idade da Suécia. Os autores encontraram que $72 \%$ das crianças suecas apresentavam hábito de sucção de chupeta, contra nenhuma criança dos outros dois grupos. Em relação a sucção de dedo, foi encontrado que $2 \%$ e $5 \%$, respectivamente, das crianças do Zimbabwe e das era de 1000 a 1500 A.C. mantinham este hábito. Os autores comentaram que esta grande diferença na prevalência de hábitos de sucção entre as diversas culturas e épocas avaliadas, sugere que a sociedade ocidental moderna, contém fatores essenciais para a instalação destes hábitos. A maioria das crianças africanas mamava no peito da mãe por 
períodos longos e freqüentes. As mães tinham redução na produção do seu leite por que trabalhavam arduamente, tiveram diversas gestações e eram subnutridas. Portanto, para alimentarem-se, as crianças necessitavam mamar com alta freqüência e intensamente. Consequentemente, a necessidade de sucção destas crianças era saciada. Por outro lado, as crianças suecas tinham facilidade em receber o aleitamento materno ou artificial, e portanto, apresentavam sua fome satisfeita, porém seu instinto de sucção, não. O desenvolvimento de hábitos de sucção é uma maneira de canalizar esta necessidade de sucção em excesso.

No ano seguinte, o mesmo autor (Larsson, 1986) fez uma revisão de literatura dos efeitos provocados pelo uso da chupeta na oclusão. O autor observou que o hábito de sucção da chupeta estava diretamente relacionado com mordida aberta anterior e um aumento na prevalência de mordida cruzada posterior. O efeito deste hábito na dentição permanente não foi muito pronunciado. Segundo o pesquisador, com o cessar do hábito, a mordida aberta se autocorrigirá após alguns poucos anos, e esta alteração está sempre associada a interposição anterior da língua.

Larsson (1986) reafirmou que a causa da mordida cruzada posterior em crianças jovens que sugam chupeta ocorre devido a um aumento na atividade muscular das bochechas associada a uma diminuição do suporte lingual da língua nos molares e caninos superiores, uma vez que a língua é forçada para trás e para baixo com o bico da chupeta. Por outro lado, a mordida cruzada na dentição decídua não necessariamente significa mordida cruzada na dentição permanente, uma vez que o hábito geralmente 
é cessado antes da erupção dos pré-molares e caninos permanentes; e mesmo nos raros casos em que o hábito persiste até a erupção do primeiro molar permanente, o efeito no sentido transversal destes dentes aparentemente não é significante. Isto por que a língua ocupa uma posição mais posterior, e assim promove o suporte lingual dos molares permanentes contra a força das bochechas.

Em uma conferência na sociedade Britânica para estudo da Ortodontia (British Society for the Study of Orthodontics), Proffit (1986) discorreu sobre a etiologia da maloclusão. O autor relatou que o estado de oclusão de um indivíduo pode ser descrito por duas características principais: a relação dos dentes em cada arco dental, o padrão de contato oclusal entre os dentes superiores e inferiores. A maloclusão geralmente ocorre devido a algum desvio do desenvolvimento normal, e não somente à patologia. Portanto, para entender a etiologia das maloclusões, deve-se considerar a influência de diversos fatores no desenvolvimento dos arcos dentais. As maloclusões se estabelecem lentamente a medida que criança cresce e se desenvolve. Assim, há grande oportunidade para diversos fatores atuarem e influenciarem o desenvolvimento normal. As influências do meio ambiente ocorrem por pressão mecânica ou forças que movem os dentes e modificam o crescimento dos maxilares. Diversos estudos foram realizados para verificar os diferentes padrões de força e seus efeitos. Um conceito importante determinado foi que a duração da pressão exercida deve ser superior a 4-6 horas por dia para ter um efeito significante. Está claro que o importante para afetar o desenvolvimento é a duração da força e 
não a sua magnitude. Portanto, hábitos mantidos por um certo período de tempo e que influenciam postura, afetam consequentemente a posição de descanso da língua, pressão de lábio, podendo, assim, afetar o padrão de desenvolvimento e causar maloclusões.

Silva Filho et al. (1986) definiram hábito como "toda ação controlada ou exercida pela musculatura intrabucal e peribucal". Tendo em vista esta definição, pode-se dizer que os hábitos bucais correspondem æ̀s funções bucais. Estes hábitos são classificados como normais ou deletérios, dependendo do efeito por eles provocados no desenvolvimento da oclusão e crescimento dos maxilares. Os hábitos normais exercem funções corretas de musculatura intrabucal e facial durante a respiração, deglutição, fonação, postura e mastigação, promovendo, portanto, um estabelecimento normal de oclusão, e favorecendo a liberação de potencial de crescimento facial, sem desvio. Por outro lado, os hábitos deletérios são aqueles cujas funções bucais constituem fatores etiológicos que podem deteriorar a oclusão ou alterar o padrão de crescimento facial normal. Alguns exemplos de hábitos bucais deletérios são: a respiração bucal, hábitos prolongados de sucção de dedo e/ou chupeta, interposição labial e funções anormais da língua durante fonação, postura ou deglutição.

Em 1986, Monguilhott discorreu sobre hábitos de sucção mantidos após os três anos e meio de idade, em crianças na faixa etária entre 5 e 11 anos, avaliando mordida cruzada posterior e aberta anterior, tipo de oclusão e cronologia e seqüência de erupção dental. Constatou que o hábito mais comum foi o da chupeta cuja prevalência foi maior nas 
meninas, mas não houve diferença estatisticamente significante entre os sexos. Praticamente todas as meninas de 6 anos de idade apresentavam hábito de sucção de chupeta e todas tinham mordida aberta anterior; mostrando, portanto, uma forte correlação entre o hábito de sucção e esta maloclusão. A mordida cruzada posterior foi observada em $23.95 \%$ das crianças com hábito de sucção.

Em revisão da literatura, Anderson (1986) evidenciou alguns pontos positivos do uso da chupeta. Como por exemplo, reduzir o choro e o estresse em crianças nascidas a termo.

Peters et al. (1986) estudaram a prevalência de mordidas cruzadas e suas relações com hábitos de sucção em crianças entre 3 e 6 anos de idade. Verificaram que a freqüência de mordida cruzada posterior prevaleceu nas crianças portadoras de hábitos de sucção, sendo que a freqüência do tipo bilateral foi de $11,55 \%$ nas crianças com hábito de sucção e 5,8\% naquelas sem este hábito. Parecia haver uma relação estreita entre hábitos de sucção e mordidas cruzadas bilaterais posteriores.

Segundo Baer \& Lester (1987), a necessidade de sucção é grande nos três primeiros meses de vida, terminando entre os 6 e 7 meses de vida. Hábitos como sugar o dedo ou chupeta ou acariciar um brinquedo são meios que as crianças lançam mão para consolar-se e sentir prazer e segurança.

Hannuksela and Väänänen (1987) investigaram a prevalência de maloclusão e seus fatores predisponentes em crianças finlandesas de 7 anos de idade. Dentre os fatores analisados, estavam os hábitos de sucção 
prolongado de dedo e chupeta, ou seja, aqueles que mantiveram o hábito após os quatro anos de vida. Os autores observaram uma correlação positiva entre aquelas crianças que ainda sugavam chupeta ou dedo após os quatro anos de idade e mordida cruzada posterior. Mordida cruzada posterior parece ser a conseqüência mais comum entre as crianças que apresentam hiperatividade atópica da mucosa nasofaríngea.

Moyers (1988) recomendava que a criança que apresentar sucção de dedo vigorosa até mais ou menos os 3 anos de idade, faça uso de chupeta ortodôntica para saciar a necessidade de sucção. Segundo o autor, este tipo de chupeta é menos deletéria em relação a oclusão do que a sucção de dedo.

Lindner \& Modéer (1989) avaliaram a relação entre hábitos de sucção e mordida cruzada posterior em crianças de 4 anos de idade. Os autores constataram que a diferença da largura dos arcos superior e inferior na região do canino estava relacionada inversamente com a intensidade e duração do hábito de sucção; o qual diminui a largura transversal da maxila em crianças e provoca a mordida cruzada posterior. Foi constatado também que os efeitos do hábito de sucção de chupeta foram mais deletérios do que o de sucção de dedo na larguras do arco na região de canino.

Kuijpers-Jagtman (1989) verificou os efeitos de sucção de dedo e chupeta no desenvolvimento dento-facial. O autor relatou que os hábitos de sucção podem influenciar separadamente cada arco dental, assim como a relação oclusal entre eles. O hábito de sucção de chupeta promove alterações no desenvolvimento dento-facial, especialmente nos planos 
verticais e transversais; enquanto o hábito de sucção de dedo provoca distúrbios nos planos ântero-posterior, vertical e transversal. Sob o ponto de vista dental e suas complicações, o hábito de sucção de dedo dever terminar antes da erupção dos incisivos permanentes e o da chupeta, antes dos três anos de idade.

Dadalto (1989) discutiu diversos fatores e aspectos do hábito de sucção de dedo e chupeta em crianças entre duas faixas etárias, 3 a 6 anos e 7 a 12 anos. A prevalência das crianças que ainda sugavam chupeta ou dedo na primeira faixa etária estudada foi de $20 \%$ e $11.4 \%$, respectivamente. Uma grande parte (44,3\%) já tivera o hábito de sucção ou de dedo ou chupeta. A porcentagem das crianças de 7 a 12 anos de idade que sugava chupeta foi bem menor $(1,6 \%)$ daquelas que sugavam o dedo $(11,2 \%)$. Foi constatado que as crianças pertencentes a nível sócio-ecômicos baixo apresentaram maior freqüência de hábitos de sucção (dedo e chupeta) persistentes do que as de nível médio-alto. As crianças que receberam aleitamento materno e cujas mães trabalhavam meio expediente apresentaram freqüência de hábitos de sucção menor. As maloclusões relacionadas com estes dois hábitos de sucção foram: trespasse horizontal aumentado, mordida aberta anterior e cruzada posterior.

Em 1990 Mathur et al. estudaram os hábitos de sucção de crianças e verificaram que $83,6 \%$ das crianças de baixo nível sócioeconômico tinham hábito de sucção de chupeta. Na maioria dos casos $(88,7 \%)$, a mãe, membro da família ou parente foi responsável por introduzir o hábito de chupeta na criança com o objetivo de acalmá-la. Os autores 
constataram que a maioria das crianças que tinha hábito de sugar a chupeta tinha associada a diarréia crônica (86,2\%) e doenças respiratórias (52,5\%).

Silva Filho et al. (1991) relataram que hábitos de sucção de chupeta ou dedo que permanecem após os 4 anos de idade são fatores importantes na determinação de maloclusões, clinicamente manifestada pela mordida aberta anterior. Os autores mencionaram também que a forma da mordida aberta é diferente dependendo de qual o hábito de sucção, dedo e/ou chupeta ou interposição lingual. Nos casos de chupeta ou dedo, a mordida aberta anterior é caracterizada por ser circular; enquanto que nos casos de interposição lingual, ela se apresenta difusa ou retangular. Quando a criança cessa o hábito de sucção durante a dentição decídua, há uma grande possibilidade da mordida aberta se autocorrigir.

Adair et al. em 1992 avaliaram as possíveis alterações provocadas nos arcos dentais de crianças entre 24 e 59 meses de idade que utilizavam chupetas ortodônticas (anatômicas) ou convencionais ou não tinham hábito de sucção de chupeta. O exame intra-bucal consistia em observar as seguintes posições anatômicas e alterações: sobremordida, sobressaliência, relação canina e terminal de molar dos segundo molares decíduos e mordida cruzada posterior. Os autores encontraram que não havia diferença estatisticamente significante quanto às relações oclusais nos planos sagital, vertical e transversal nas crianças que utilizavam chupetas ortodônticas quando comparadas àquelas que utilizavam chupetas convencionais. No grupo que utilizava chupetas convencionais, havia um número maior de crianças que apresentava sobremordida maior ou igual a 
$50 \%$ (traspasse vertical do incisivos superiores sobre os inferiores). Neste mesmo grupo, também foi constatado que havia uma proporção maior de mordida aberta anterior do que no grupo sem hábito e no grupo de chupeta ortodôntica. Existiu uma tendência de relação entre as horas de uso diário da chupeta com o grau de mordida aberta anterior. Não foi encontrada relação estatisticamente significante entre as horas de uso por dia e duração do hábito com maloclusão nas crianças que utilizavam chupeta. Também não foi observado diferença estatisticamente significante quanto a mordida cruzada posterior nos três grupos avaliados.

$\mathrm{Na}$ introdução do estudo (Adair et al., 1992), os autores mencionaram que as chupetas e bicos de mamadeiras ortodônticos NUK ${ }^{\mathrm{TM}}$ foram introduzidos em meados dos anos 50 nos Estados Unidos. O desenho destes bicos e chupetas promove movimentos musculares semelhantes àqueles realizados pela criança durante o aleitamento materno, e portanto, um desenvolvimento normal dos arcos dentais, segundo os autores.

Em 1993, Paunio et al. estudando a relação entre hábitos de sucção, maloclusão e contexto familiar em crianças finlandesas de três anos de idade, encontraram que $23,4 \%$ das crianças mantinham hábito de sucção de chupeta e $1,7 \%$ de dedo. O aleitamento materno prolongado estava relacionado à diminuição da prevalência de hábito de uso de chupeta. $\mathrm{O}$ hábito de sucção de chupeta estava associado à mordida aberta anterior e mordida cruzada posterior, enquanto que sucção de dedo apenas àmordida aberta anterior. Os autores ainda relataram que o uso de chupeta é uma maneira que os pais usam para acalmar as crianças e que este estava 
associado positivamente à negligência na supervisão da higiene oral da criança.

Larsson et al. (1993) investigaram os hábitos alimentares, de aleitamento e de sucção de 362 crianças de três cidades da Noruega e Suécia. Os autores encontraram que as crianças que receberam aleitamento materno por um período médio de 7,6 meses. Observaram também uma correlação inversa entre o aleitamento materno e o artificial, sendo que um período menor de aleitamento materno correspondia a um período de aleitamento artificial maior, e vice-versa. Outro fato observado em apenas uma das três cidades, foi uma correlação entre o tempo de aleitamento materno e o desenvolvimento de hábitos de sucção, sendo que aquelas crianças que foram aleitadas por suas mães por período prolongado, acima dos 10 meses, apresentavam menor prevalência de hábitos bucais.

Patrício (1993) estudou a correlação entre mordida aberta anterior e relação terminal dos segundos molares decíduos em crianças de 25 a 61 meses de idade. A mordida aberta anterior de até três milímetros foi constatada como a mais freqüente. Além disso, verificou também a tendência desta diminuir com o aumento da idade.

Marigo \& Frauches (1993) ao analisar os hábitos bucais nocivos à oclusão dentária e correlacioná-los com nível sócio-econômico em crianças entre 6 e 10 anos de idade da cidade de Governador Valadares, Minas Gerais, constataram que as crianças pertencentes ao nível econômico mais baixo, apresentaram a maior prevalência de hábitos bucais deletérios. Entre os hábitos bucais nocivos mais freqüentes encontrados nesta população, 
podem-se destacar os seguintes: deglutição atípica $(30,7 \%)$, onicofagia $(17,2 \%)$, respiração bucal $(15,7 \%)$ e sucção digital $(13,9 \%)$. O hábito de sucção de chupeta estava presente em 12,3\% das crianças de nível sócioeconômico baixo e em 9,4\% daquelas pertencentes aos níveis médio e alto. Os autores também ressaltaram a falha dos cirurgiões-dentistas quanto a orientação e eliminação dos hábitos bucais nocivos nos seus pacientes; uma vez que das 688 crianças que já tinham ido ao dentista, 516 eram portadoras de algum tipo de hábito nocivo.

Em revisão da literatura, Larsson (1994) observou que o uso impróprio da chupeta poderia provocar efeitos desastrosos na oclusão quando, por exemplo, a criança utiliza o escudo da chupeta dentro do lábio inferior ou morde-o. Fora estes casos, os efeitos provocados pelo uso da chupeta se limitam aos planos vertical e transversal. Uma das alterações mais óbvias encontradas em crianças que sugavam chupeta foi a mordida aberta anterior, a qual estava associada a interposição de língua. Esta alteração, sofrerá auto correção com a interrupção do hábito, apesar da interposição lingual permanecer. A mordida cruzada posterior estava relacionada mais freqüentemente às crianças que tinham o hábito de sucção de chupeta do que naquelas com hábito de dedo. Reafirmando o que escreveu em estudos anteriores, o autor mencionou que quando a criança suga a chupeta, o bico desta permanece na parte ântero-superior e média da cavidade bucal, forçando a língua a uma posição mais baixa. Com esta posição, os dentes da região do canino não têm apoio da língua na face palatino durante a função da bochecha na deglutição; promovendo, então, 
uma redução na largura do arco dental e aumentando o risco de uma márelação transversal. A posição inferiorizada da língua provoca ainda um alargamento no arco inferior, portanto aumentando ainda mais as chances de estabelecer uma mordida cruzada posterior. $\mathrm{O}$ autor alertou para o fato que, quando a diferença entre o distância intercanina do arco superior e inferior for menor que $3 \mathrm{~mm}$, a criança apresenta maior risco a desenvolver mordida cruzada posterior; e nos casos de mordida cruzada unilateral já instalada e associada com posicionamento lateral de mandíbula, deve-se imediatamente fazer desgastes na dentição decídua para ajustar a oclusão.

Øgaard et al. (1994) realizaram um estudo com crianças de três anos de idade de quatro cidades da Suécia e Noruega, para verificar os efeitos das seguintes características na mordida cruzada posterior: relação canina, hábitos de sucção e local de residência. Os pais responderam a um questionário sobre os hábitos de sucção, presentes ou passados, de seus filhos. A distância intercanina destas crianças foi comparada com estas mesmas medidas obtidas de crânios de crianças da era medieval da região da Escandinávia que datavam de 1000 a 1500 A.C. Os autores encontraram que a prevalência de mordida cruzada posterior foi maior nas crianças que mantinham hábito sucção de chupeta e dedo quando comparadas àquelas sem hábito de sucção. Encontraram também que a mordida cruzada posterior podia ser prevista através da distância intercanina dos arcos inferior e superior, uma vez que o uso de chupeta diminui esta distância no arco superior e aumenta no arco inferior. Também foi verificado que pelo menos dois anos de hábito de sucção de chupeta são necessários para 
produzir alteração significante na largura do arco superior e três anos no arco inferior. Foi encontrado que quanto maior o tempo de uso da chupeta, maior foi seu efeito na distância intercanina dos arcos dentais, diminuindo o arco superior e aumentando o arco inferior. Eles afirmaram que o uso de chupeta é fator importante no desenvolvimento de mordida cruzada posterior.

Tomasi et al. (1994) discutiram os fatores determinantes e padrões do uso da chupeta em crianças menores de dois anos de idade na cidade de Pelotas, Rio Grande do Sul. Os investigadores encontraram que $80 \%$ dos pais ofereceram a chupeta aos seus filhos na maternidade, sendo que $62 \%$ o fizeram já no primeiro dia de vida. As mães alegaram que tomaram esta atitude para acalmar a criança, por causa do choro ou por ser de costume. Foi constatado também uma relação inversa entre a escolaridade materna e uso intenso da chupeta, e entre o uso da chupeta e amamentação materna, onde praticamente metade das crianças amamentadas por ocasião do estudo não usava chupeta, contra $7 \%$ das demais crianças.

Em 1994, Coeli \& Toledo discorreram sobre a etiologia e tratamento dos hábitos de sucção, por meio de revisão da literatura. Destacam que o hábito de sucção funcionava como válvula de escape nos casos de pressões emocionais e físicas do mundo exterior; além de proporcionar prazer e satisfação. O uso de chupeta nos primeiro meses de vida pode auxiliar na prevenção da instalação do hábito de sucção de dedo. Acrescentam ainda que, as crianças que foram aleitadas pelas suas mães 
por um período de tempo longo, foram menos susceptíveis ao hábito de sucção de dedo.

Adair et al. (1995) conduziram um estudo com 218 crianças entre 24 e 59 meses de idade para investigar os efeitos do uso de chupetas ortodônticas e convencionais na oclusão dental, comparando-as com crianças que não apresentavam hábito de sucção não nutritivo. Um questionário foi enviado para os pais a fim de obter informações sobre o hábito de sucção. A idade média das crianças estudadas foi de 43,9 meses, sendo que 48,2 \% eram do sexo masculino. Não houve diferença significante entre os grupos experimentais com relação ao sexo, idade média ou raça. No exame clínico foram observadas as seguintes características: relação canina, relação terminal dos segundo molares decíduos, grau de sobremordida, e dimensão da mordida aberta anterior, cruzada posterior e sobressaliência, em milímetros. As crianças que utilizavam chupeta, tanto ortodôntica quanto convencionais, estavam significantemente mais predispostas a apresentarem um sobressaliência maior ou igual a 4 milímetros, mordida aberta anterior e mordida cruzada posterior do que aquelas que nunca utilizaram chupeta. Não houve diferença estatisticamente significante entre a média de sobressaliência e mordida aberta (em milímetros) e prevalência de mordida aberta anterior ou cruzada posterior, entre as crianças que utilizavam chupeta anatômica (ortodôntica) ou convencional. Foi observado que um maior tempo de uso de chupeta estava associado à mordida aberta anterior e cruzada posterior. A mordida aberta anterior e cruzada posterior foram, respectivamente, cinco e três vezes mais 
freqüentes nas crianças que sugavam chupeta do que naquelas sem o hábito. Os autores não encontraram diferença estatisticamente significante entre a intensidade do uso da chupeta (hora por dia) e nenhum dos aspectos de maloclusão observados. A relação canina Classe II também foi mais freqüente nas crianças com hábito de sucção de chupeta do que naquelas sem o hábito. Os autores concluíram que aparentemente não havia vantagem entre a chupeta ortodôntica e a convencional.

Turgeon-O'Brien et al. (1996), em revisão da literatura sobre hábitos de sucção nutritivos e não nutritivos, descreveram que segundo os fabricantes das chupetas ortodônticas, estas apresentam algumas vantagens como: adaptar-se aos lábios do bebê e permitir respiração nasal, simular o bico da mãe quando do aleitamento, permitir que a língua toque o palato numa posição mais natural para sugar e também melhorar o vedamento labial. Por outro lado, os autores relataram que há poucos dados científicos para apoiar a troca das chupetas convencionais pelas ortodônticas ou fisiológicas e que mais estudos são necessários nesta área. No mesmo ano (1996), Chan et al. realizaram um estudo cefalométrico dos efeitos esqueléticos e dentários em crianças entre 7 e 10 anos de idade que apresentavam hábito persistente de sucção de chupeta. Os autores observaram que o hábito persistente de sucção de chupeta, não teve influência sobre as características esqueléticas, e portanto, não foi capaz de alterar permanentemente medidas esqueléticas faciais. Por outro lado, foi verificado um aumento da sobressaliência e redução da sobremordida, (mordida aberta anterior) no grupo de crianças que mantinha 
o hábito de sucção de chupeta. Os autores verificaram também que a freqüência do hábito sucção de chupeta, não foi um fator significante no agravamento das alterações dento-alveolares (sobressaliência e sobremordida).

Soares \& Totti (1996) definiram hábito como "padrões de contração muscular aprendidos de natureza complexa", sendo que ele pode estimular o crescimento normal dos maxilares ou ser fator etiológico das maloclusões de caráter muscular, esquelética ou dentária. Neste último caso, denominado de hábito deletério. Padrões anormais e função da musculatura deletéria geralmente estão associados com más posições dentárias, crescimento ósseo impedido ou anormal e distúrbio respiratórios. Para determinar se um hábito é deletério ou não, deve-se avaliar sua característica quanto a freqüência, duração e intensidade, assim como a interação com o padrão de crescimento da paciente. Os hábitos que forem mantidos após os três anos de idade, ou apresentarem alta freqüência durante o dia e a noite, serão considerados mais deletérios e capazes de provocar maloclusões mais severas.

Lindsten et al. (1996) verificaram o efeito da sucção de chupeta de crianças de três anos de idade da Noruega e Suécia. Os resultados encontrados levam a acreditar que o uso de chupeta altera a largura do arco dental, e portanto aumenta a probabilidade de desenvolver mordida cruzada posterior.

Adair (1996) definiu sucção não nutritiva como sendo o ato de sugar um objeto, geralmente a chupeta ou dedo, não relacionado a nutrição 
ou alimentação. O efeito da sucção não nutritiva na dentição depende de alguns fatores como, sua duração, intensidade, freqüência, modo de uso e idade do término. Há evidências que algumas maloclusões provocadas por sucção não nutritiva se auto corrijam se a criança cessar o hábito em tenra idade. O autor descreveu algumas alterações que o hábito de sucção de chupeta ou dedo podem provocar. Relatou que estes dois hábitos poderiam provocar alterações semelhantes na dentição e relação dos arco dentais. Existem poucas evidências que o uso de chupeta provoque efeitos menos danosos que a sucção de dedo, porém isto não é unânime em todos os estudos. Dentre as alterações provocadas por sucção não nutritiva, pode-se mencionar as seguintes: aumento da sobressaliência, diminuição da sobremordida, mordida cruzada posterior, molares em relação Classe II, inclinação dos incisivos e aumento no risco de trauma dental. Por outro lado, a sucção não nutritiva apresenta alguns benefícios como acalmar a criança. Em bebês pré-maturos, o uso de chupeta aumenta o tempo de sono e diminui o período de impaciência.

Segundo Norman (1997), a primeira associação que a criança faz com o prazer está relacionada a sucção e alimentação. O ato de sugar aumenta a produção de endorfina, o que produz sensações de conforto, relaxamento, prazer. Portanto, não é difícil de entender por que o hábito de sugar a chupeta ou dedo se torna uma enorme fonte de prazer, conforto e satisfação para a criança. $O$ autor menciona ainda que quando é oferecida a chupeta à criança, e ela descobre as sensações físicas prazerosas e de conforto provenientes do ato de sugar, a criança inicia a sucção de maneira 
inconsciente, para relaxar, dormir, quando está com fome, medo excitada, apreensiva ou física e emocionalmente estressada.

Farsi et al. (1997) investigaram os hábitos de sucção de 583 criança da Arábia Saudita na faixa etária de 3 a 5 anos de idade por meio de questionário para os pais e de exame clínico. O questionário abordava assuntos como idade da criança, aleitamento materno, educação e situação econômica dos pais, e aquelas referentes ao hábito de sucção (tipo, duração e freqüência. As características observadas foram as seguintes: relação terminal distal dos segundos molares decíduos, relação canina, grau de sobremordida (menos que ou igual à $50 \%$ de traspasse vertical do incisivo superior sobre o inferior, mais que $50 \%$ de traspasse, topo a topo ou mordida aberta anterior); sobressaliência (medida pela superfície lingual da face mesial do incisivo superior mais protruído até a superfície vestibular do incisivo inferior correspondente); mordida cruzada posterior (quando um ou mais dentes da região de canino a molares ocluiam palatinamente a cúspide vestibular do dente antagonista). De todas as crianças avaliadas, 37,90\% tiveram ou ainda tinham hábito de sucção de chupeta, porém apenas $2,2 \%$ destas ainda continuavam com o hábito até o momento do estudo. Não houve diferença estatisticamente significante quanto ao sexo da criança e sucção de dedo ou chupeta. Com aumento da idade de 3 para 5 anos de idade, diminuiu a prevalência de sucção de chupeta (aos 3 anos de idade, $5,76 \%$, aos 4 anos de idade 2,27\% e aos 5 anos idade $0,77 \%$ ). Quanto a idade, do total de 583 criança, 104 estavam na faixa etária de 3 anos, 220 na de 4 anos de idade, e 259 nas de 5 anos. A maioria das crianças que 
sugavam chupeta $(87,32 \%)$ utilizava a chupeta convencional (com bulbo arredondado e longo e escudo sem suporte para musculatura labial). Para mais da metade das crianças que mantinha algum hábito de sucção, a intensidade do hábito foi de 2 a 5 horas por dia. Os fatores ou variáveis que influenciaram ou estavam relacionados ao hábito de sucção de chupeta foram o nível educacional dos pais e período de aleitamento materno (quanto maior o nível de escolaridade dos pais, menor a porcentagem de crianças que utilizavam chupeta; e um período de aleitamento materno superior a 6 meses de idade, menor a prevalência de sucção digital e de chupeta). Outras variáveis como nível econômico ou posição da criança na família não apresentaram nenhuma influência quanto aos hábitos de sucção digital ou de chupeta. A mordida cruzada posterior não teve nenhuma correlação positiva com o grupo de hábitos de sucção ou grupo controle (sem nenhum hábito). Das crianças que mantiveram o hábito de sucção de chupeta, $50 \%$ tinham relação molar distal, mordida aberta anterior e sobressaliência igual ou superior a 50\% e 58,33\% apresentavam relação canina classe II. Foi encontrada uma forte relação positiva entre os hábitos de sucção persistentes e relação molar distal, relação canina Classe II, mordida aberta anterior e protrusão. Nenhuma destas crianças apresentava mordida cruzada posterior. Enquanto que mais ou menos $5 \%$ das crianças do grupo controle e de sucção digital apresentavam mordida cruzada posterior. Quanto ao grupo controle, 4,66\% tinha relação molar distal, 6,81\% relação canina Classe II, 3,58\% mordida aberta anterior e 8,60\% sobressaliência de $4 \mathrm{~mm}$ ou mais. 
Os autores (Farsi et al., 1997) mencionaram que os hábitos de sucção são influenciados pelas práticas e tradições de cuidado com as crianças; por isso, há uma grande variedade de prevalência quanto aos hábitos de sucção dentre as diferentes populações.

Estudando a relação entre aleitamento, hábitos bucais e maloclusões em crianças na faixa etária de 3 a 5 anos, Serra-Negra et al. (1997) verificaram que $75 \%$ das crianças examinadas apresentavam algum hábito bucal deletério, sendo o da chupeta o mais comum, seguido por onicofagia, sucção de dedo e ato de morder objetos. A maioria $(86,1 \%)$ das crianças que recebeu o aleitamento materno não apresentou hábitos bucais deletérios. Foi constatado também que as crianças, que nunca receberam o aleitamento materno ou o fizeram somente até o primeiro mês de vida, apresentavam risco sete vezes maior de desenvolver hábitos deletérios de sucção quando comparadas às crianças que receberam aleitamento materno por um período mínimo de 6 meses de idade; e, as crianças que receberam aleitamento artificial por um período superior a um ano apresentavam risco dez vezes maior de desenvolver algum hábito bucal deletério do que aquelas que nunca utilizaram a mamadeira.

Ainda no mesmo estudo, Serra-Negra et al. (1997) observaram que a prevalência de mordida cruzada posterior foi superior nas crianças que apresentavam algum hábito bucal deletério $(23,9 \%)$ quando comparadas æ̀s crianças sem hábito (7\%). Assim, as crianças com algum hábito deletério têm risco quatro vezes maior de desenvolver mordida cruzada posterior do que as crianças sem hábitos. Ao relacionar o traspasse vertical com hábitos 
deletérios, a mordida aberta foi a alteração mais freqüente (31,9\%). Crianças que apresentavam algum hábito de sucção deletério, tinham risco quatorze vezes superior em desenvolver mordida aberta anterior do que aquelas sem este comportamento. Sobressaliência aumentada foi encontrada em 15.6\% das crianças que tinham algum hábito, contra $9.3 \%$ daquelas que não mantinham nenhum hábito bucal deletério.

Ferreira \& Toledo (1997) avaliaram a relação entre o tempo de aleitamento materno e hábitos bucais em 427 crianças entre 3 e 6 anos de idade. Foi verificado que nas crianças que receberam aleitamento materno por um período superior a 6 meses de idade, a freqüência de hábitos de sucção foi menor. Portanto, pôde-se afirmar que houve uma associação entre o hábito de sucção e o tempo de aleitamento materno.

Vadiakas et al. (1998) verificaram a prevalência e fatores associados aos hábitos de sucção não-nutritivos em crianças na faixa etária de 3 a 5 anos de idade da Grécia. Os pais responderam a um questionário referente a duração dos tipos de aleitamentos e intensidade, freqüência e duração dos hábitos de sucção não nutritivos. Os autores encontraram que a maioria das crianças $(81 \%)$ tinha sido amamentada no peito até pelo menos o primeiro mês de vida. Observou-se que a prevalência de sucção de chupeta diminuía com aumento da idade da criança. Houve uma tendência da prevalência de sucção de chupeta diminuir com aumento do período de aleitamento materno (maior que 6 meses de idade). Foi encontrada uma relação entre os uso da mamadeira e hábito de sucção de chupeta, sendo que mais que $50 \%$ das crianças com o estes hábito utilizaram mamadeira. 
As crianças do estudo cessavam o hábito de sucção de chupeta em idade mais precoce do que sucção de dedo.

Camargo et al. (1998) afirmaram que o uso da chupeta representam perigo para oclusão dependendo do modo como é utilizada, ou seja, da freqüência e do tempo de uso. Caso estes sejam prolongados, o hábito é instalado, impedindo contato dos lábios, provocando desvio na direção do crescimento maxilar e ocupando o espaço funcional da língua. Todas estas alterações na direção de crescimento, funções da língua e falta de vedamento labial podem acarretar a instalação de maloclusões até mesmo na fase de rodetes gengivais.

Cunha et al. (1998) descreveram que o grau de severidade das alterações provocadas pela sucção não nutritiva, como o hábito de sugar a chupeta ou dedo, depende de alguns fatores relacionados ao hábito em si e outros com a criança. Dentre aqueles relacionados ao hábito pode-se mencionar duração, freqüência, intensidade e idade de término do hábito. Os fatores ligados à criança são: padrão de crescimento e grau de tonicidade da musculatura bucofacial. As alterações bucais provocadas por hábitos de sução não nutritivos são as seguintes: mordida aberta anterior com contorno circular, inclinação dos incisivos centrais superiores para vestibular e retroinclinação dos inferiores, mordida cruzada posterior, diminuição da largura do arco dental superior devido a alta atividade muscular na região dos molares. As autores comentaram que é melhor o hábito de sucção de chupeta do que dedo, por que a remoção do hábito do primeiro é mais fácil. Alertaram para o fato que a correção espontânea da mordida aberta anterior 
quando do término do hábito, mencionada por diversos autores, pode sofrer influências de outros hábitos como respiração bucal e projeção e interposição de língua. As autores também descreveram algumas orientações importantes que devem ser dadas aos pais. Quanto ao uso da chupeta, os pais só devem oferece-la em momentos de tensão e ansiedade do bebê e não utilizá-la para parar com o choro da criança; não devem prendê-la com correntinhas. A chupeta deve ser ortodôntica ou anatômica, adaptando-se a cavidade bucal da criança e ajustando-se ao palato e à língua. O disco ou escudo de plástico deve ter perfurações para evitar o acúmulo de saliva e formato côncavo.

Moreira (1998) orientou para que a chupeta seja utilizada nos momentos necessários, quando o bebê estiver irritado ou sonolento após as mamadas. Deve-se remover a chupeta cuidadosamente da cavidade bucal da criança, assim que ela adormecer, para que a criança não se habitue com o sugar intermitente da chupeta. A autora recomenda que a chupeta seja utilizada de maneira disciplinada e que seja do tipo anatômico (funcional ou ortodôntico) por que apresentam semelhança com o mamilo materno.

Coletti \& Bartholomeu (1998) estudaram o hábito de sucção de dedo e chupeta nas crianças na faixa etária de 3 a 6 anos de idade por meio de 94 formulários respondidos pelos pais. No questionário, havia perguntas relacionadas ao ambiente familiar da criança, gestação, aleitamento materno, uso de mamadeira, modo de uso da chupeta e motivo do início do hábito, entre outros. Os resultados obtidos demostraram que a ausência do pai ou da mãe e o uso da mamadeira atuaram como fatores predisponentes 
para os hábitos de sucção e que filhos únicos não apresentaram maior prevalência de hábitos de sucção que as crianças que tinham irmãos. Foi observado também que o aleitamento materno prolongado diminuiu a freqüência de hábitos de sucção. Na maioria das vezes $(88,4 \%)$, o início do hábito de sucção de chupeta ocorreu logo após nascimento para acalmar o bebê ou por costume. A maioria das crianças utilizava a chupeta para dormir ou sem motivo aparente. A mamadeira foi introduzida em média aos 5,6 meses e $37,9 \%$ das crianças ainda a utilizavam até o momento do estudo.

Estudando a influência do período de aleitamento materno nos hábitos de sucção persistentes e maloclusões em crianças entre 2 e 6 anos de idade, Robles et al. (1999) observaram que $85,19 \%$ das crianças que receberam aleitamento materno até os 9 meses de idade, usaram a mamadeira além dos dois anos. Por outro lado, as crianças que cessaram o aleitamento materno entre 4 e 7 meses de idade, foram as que menos utilizaram a mamadeira após os dois anos de idade. Alta prevalência de hábitos de sucção persistente (dedo ou chupeta) foi encontrada nas crianças que não receberam aleitamento materno (60\%) ou o fizeram até os 3 meses de idade $(71,74 \%)$. Foi verificado que a vasta maioria $(94,44 \%)$ das crianças com hábitos de sucção persistente apresentava maloclusões aos dois anos de idade.

Em 1999, Serra-Negra et al. estudaram os hábitos de sucção de chupeta de 156 crianças de 2 a 12 anos de idade, por meio de questionário aplicado às mães. A maioria das mães relatou ter oferecido chupeta aos seus filhos, sendo $34,9 \%$ do tipo ortodôntico, $28,1 \%$ das convencionais e 
$28,1 \%$ de ambos os tipos. Os autores encontraram que o uso das chupetas convencionais foi mais freqüente na classe social não favorecida $(66,7 \%)$ e nas crianças cujas mães tinham baixo nível de escolaridade, e a ortodôntica na classe social favorecida (68,5\%). Relacionando o tempo de uso da chupeta com classe social, foi visto que mais da metade das crianças da classe social favorecida, utilizou a chupeta por um período menor que três anos, e as da classe social não favorecida $(65,2 \%)$, por um período maior que este. Após calcular o odds ratio destes dados, foi verificado que as crianças da classe social menos favorecida apresentavam três vezes mais chance de permanecerem com o hábito por período de tempo maior que as crianças da classe social favorecida. Observaram também, que o modelo de chupeta ortodôntica foi mais utilizado por crianças cujas mães tinham alta escolaridade $(48,1 \%)$, e a convencional nas crianças de mães com escolaridade baixa $(49,1 \%)$. Uma boa parte das mães $(43,3 \%)$ com alta escolaridade relatou que a vantagem do uso da chupeta era tranqüilizar a criança; enquanto que as mães de baixa escolaridade $(44,8 \%)$ não viam vantagem em utilizá-la.

No mesmo ano (1999), Modesto et al. avaliaram o conhecimento das mães sobre o uso e as características das chupetas oferecidas aos seus filhos no seu primeiro ano de vida. Por meio de entrevista, as 180 mães participantes do estudo foram indagadas a respeito do recebimento de orientações sobre o tipo de bico e disco ou escudo da chupeta mais satisfatório, o motivo de ter oferecido a chupeta à criança e freqüência de uso desta, entre outras. Mais da metade $(61,3 \%)$ das mães ofereceu a 
chupeta aos seus filhos, das quais $87,8 \%$ acreditou que o uso deste artifício poderia levar a alguma alteração nos arcos dentais. Praticamente esta mesma proporção de mães $(83,7 \%)$ achava que o objetivo do uso da chupeta era acalmar a criança. Grande parte das mães $(85,7 \%)$ usava prendedor ou fralda para segurar a chupeta à roupa da criança. Quanto à freqüência do seu uso, $65,3 \%$ das crianças o faziam dia e noite e $28,6 \%$ para dormir. Observaram também as chupetas utilizadas pelas crianças. Os autores encontraram que $67,3 \%$ dos bicos e $53,1 \%$ dos discos ou escudos eram potencialmente prejudiciais aos desenvolvimento orofacial. Os autores ainda relataram que a chupeta faz parte do enxoval do criança devido a uma imposição cultural. Em diversas publicações especializadas para gestantes, a chupeta é mencionada como uma peça indispensável do enxoval do bebê. Propõem uma outra nomenclatura para as chupetas "ortodônticas", por que esta terminologia induz a mãe a achar que a chupeta é benéfica, ou seja, ela relaciona o termo ortodôntico com correção e imagina que há um benefício corretivo ao utilizar esta chupeta. Assim, propuseram a terminologia de chupeta anatômica para aquelas mais satisfatórias; uma vez que ela deve ser coerente com as formas e funções da cavidade bucal. Porém, os autores ressaltaram que o uso freqüente e por tempo prolongado da chupeta, mesmo do modelo anatômico, provoca alterações na cavidade bucal e desvio na direção de crescimento maxilo-mandibular.

A Academia Americana de Pediatria (1999/2000) recomenda que o hábitos "anormais" sejam identificados e que se faça uma avaliação dos efeitos no complexo crânio-facial e nas dentições o mais precocemente 
possível. Deve-se tratar o hábito bucal quando este está provocando algum dano ou há evidência que este possa trazer seqüelas para a dentição permanente em desenvolvimento.

Tomita et al. (2000) avaliaram em 2.139 crianças, na faixa etária de 3 a 5 anos de idade, a maneira pela qual o desenvolvimento de hábitos bucais deletérios e os problemas de fala afetaram a oclusão dental. Encontraram a maior prevalência de maloclusão na faixa etária dos três anos de idade, e esta diminuía com a idade. O hábito de sucção de chupeta foi o mais importante na associação àmaloclusão. Um parte expressiva das crianças que sugavam chupeta $(81,2 \%)$ apresentava maloclusão. Não foi observada associação entre problemas de fala e maloclusão. Os autores constataram que a sucção de chupeta é um fator de risco àmaloclusão de maior intensidade que a sucção digital, uma vez que ela foi 5,46 vezes maior nas crianças que tinham o hábito de sugar a chupeta em relação àquelas que não tinham esta hábito e 1,54 vezes mais freqüente naquelas com o hábito de sucção digital.

Gimenez et al. (2000) investigaram a prevalência e tipos de maloclusões em 226 crianças na faixa etária de 2 a 4 anos. Correlacionaram também a maloclusão presente com a forma de aleitamento e hábitos bucais inadequados. Os resultados encontrados mostraram uma alta prevalência de maloclusões e uma correlação positiva entre a falta de aleitamento materno, hábitos bucais inadequados e ausência de vedamento labial e as maloclusões instaladas. Outro fato observado foi que a chupeta revelou-se como a variável mais significativa na instalação das maloclusões. Os 
autores ainda alertaram quanto a necessidade de uma prática de saúde bucal mais abrangente, que não enfoque apenas a prevenção da doença cárie, mas que considere o paciente de maneira integral, permitindo o desenvolvimento adequado de todo o sistema estomatognático.

Espindola et al. (2000) estudaram os conhecimentos e atitudes de mães de 85 recém-nascidos em relação ao aleitamento e à sucção não nutritiva no Hospital Universitário - UERJ (HUPE). A maior parte das mães $(68,2 \%)$ tinha feito o pré-natal neste mesmo hospital ou em outros hospitais (29,5\%). De todas as mães, 60,0\% comparam mamadeira e 43,2\% chupeta; porém, aquelas que fizeram o pré-natal nesta instituição, foram as que menos comparam estes dois artifícios, sendo esta redução estatisticamente significante apenas para a chupeta. Os autores também encontraram que o pré-natal favoreceu a prática do aleitamento materno e a não introdução de bicos artificiais.

\subsection{Estruturas miofuncionais orais e hábitos de sucção não nutritivos}

Em estudo longitudinal para verificar os efeitos provocados pelos hábitos de sucção de chupeta e de dedo, Bowden (1966b) constatou que a prevalência de crianças que apresentavam incompetência e interposição labial era maior naquelas que tinham algum hábito de sucção quando comparadas aquelas sem estes hábitos. Assim como a interposição de língua e descanso da língua no lábio foram freqüentemente observados nas crianças com hábito de sucção deletério. Não houve diferença 
estatisticamente significante entre mordida cruzada posterior e respiração nasal ou mista, tanto nas crianças com hábito de chupar chupeta ou dedo.

Como foi descrito anteriormente, Margolis (1980) corrigiu em criança de 2 anos e meio de idade, mordida aberta anterior provocada pelo uso de chupeta convencional (bulbo longo e arredondado), com o uso de chupeta ortodôntica NUK ${ }^{\mathrm{TM}}$ exerciser. Este autor mencionou que as chupetas ortodônticas apresentam desenho do bulbo tal que se adapta a posição da língua e promove um correto padrão de deglutição. Estas chupetas também contém um escudo labial no qual os lábios são pressionados durante a sucção, fortalecendo os músculos orbiculares orais.

Estudando as alterações funcionais relacionadas aos hábitos de sucção de dedo ou chupeta, Dadalto (1989) comentou que aquelas diretamente ligadas a estes hábitos foram: deglutição, respiração e fonação atípica e lábios abertos na posição de repouso.

Black et al. (1990) relataram que os desvios da posição dos dentes provocados pela sucção de polegar e chupeta dependem essencialmente da intensidade, duração diária e força do hábito . Nos pacientes que apresentam sucção de chupeta as seguintes características foram observadas: alterações musculares lingual e labial com diminuição da tonicidade, palato ogival, incompetência labial, língua com posicionamento rebaixado, protrusa e com maior mobilidade dorsal, mordida aberta anterior, protrusão dos incisivos superiores e hipo-desenvolvimento da mandíbula. 
Lindner \& Hellsing (1991) avaliaram a pressão exercida pelas bochechas e pelos lábios no arco superior quando da sucção de chupeta. $O$ estudo foi realizado em 12 crianças com idade variando de 6 a 12 anos, que já tiveram o hábito de sucção de chupeta ou ainda o tinham; sendo que todas tinham relação molar Classe I e sobressaliência e sobremordida normais. O valor médio da pressão na região de canino foi de $54 \mathrm{~g} / \mathrm{cm}^{2}$ e na região dos molares decíduos de $21 \mathrm{~g} / \mathrm{cm}^{2}$. Portanto, a pressão na região dos caninos foi praticamente três vezes maior do que na região dos segundos molares decíduos. Os autores acreditam que isso possa ser explicado pela posição mais vestibular que os caninos ocupam na cavidade bucal e estando assim, mais perto dos músculos periorais do que os segundos molares decíduos.

Em 1993, Marchesan afirmou que as funções de mastigação, sucção, deglutição, fonação, articulação e respiração são próprias do sistema estomatognático. A sucção é um reflexo da própria espécie, pois ela nasce com o indivíduo. No bebê, a sensibilidade tátil dos lábios é maior do que a das polpas digitais, por isso, ele leva tudo a boca. Durante 0 ato de sugar, o músculo bucinador é o que apresenta maior atividade. Segundo a autora, as bochechas têm como função auxiliar durante a mastigação a manutenção do alimento sobre os dentes, realizando movimentos contrários ao da língua. Quando se observa que as bochechas estão "caídas", geralmente sua função está diminuída. Nestes casos, observa-se o acúmulo de restos alimentares no vestíbulo lateral. Outra alteração miofuncional é o palato duro estreitado. Este é 
decorrente, muitas vezes, da posição da língua mais inferiorizada na cavidade bucal, levando a uma dificuldade de colocar a língua nessa região (Marchesan, 1993).

Gomes et al. (1993) descreveram que o uso prolongado de chupeta, após os dois anos de idade, tende a provocar uma diminuição no tonus muscular da língua e lábios, devido a posição que a chupeta permanece em relação a estas estruturas. Quando da utilização da chupeta convencional, a criança tenderá a manter a boca entreaberta, movimentar mais o dorso da língua com a ponta da língua protruída e rebaixada. Os lábios apresentam hipofunção devido a falta de trabalho muscular. O bico da chupeta encaixa-se no palato duro e este é empurrado pelo dorso da língua. As alterações provocadas pelo uso da chupeta são incompetência labial, mordida aberta anterior, palato ogival, hipodesenvolvimento de mandíbula e protrusão dos dentes incisivos superiores. As autoras acreditavam que quando a criança ainda é alimentada por mamadeira e apresenta o hábito de chupeta, deve-se orientar a mãe para substituir o bico da mamadeira e da chupeta pelos tipos ortodônticos. O bico de mamadeira ortodôntico permite que o aleitamento artificial seja o mais próximo da natural. O desenho deste tipo de bico, permite que haja estímulo para trabalhar a musculatura anterior, e promovendo um padrão mais maduro de deglutição e propiciando a prevenção de algumas alterações morfológicas. A chupeta ortodôntica também exercita a musculatura anterior. 
Segundo Schwartz \& Schwartz (1994), dentre os fatores locais etiológicos primários das maloclusões estão "as partes moles". Assim, qualquer fator que altere a fisiologia de alguma parte do sistema mastigatório poderá ser indicado como importante fator etiológico da maloclusão.

Moresca e Feres (1994) mencionaram que em repouso, há um equilíbrio entre os músculos e todos os tecidos periorais. Quando há uma quebra desse equilíbrio, geram-se pressões anormais resultando em alteração do estímulo de crescimento anormal dos maxilares e das funções bucofarígeas. A maloclusão é conseqüência da interação de diversos fatores que afetam o sistema em desenvolvimento, que apresenta um próprio padrão de crescimento.

Em 1995, Ahlgren verificou a atividade de lábios e bochechas na presença de hábitos de sucção. Foi constatada atividade muscular evidente do lábio e mentalis (perioral) durante a sucção de dedo e chupeta. A atividade do músculo bucinador (bochecha) foi menos evidente, apresentando apenas uma atividade leve a moderada durante estes hábitos de sucção; porém, a atividade de lábios e bochecha foi mais evidente nas crianças com hábito de sucção de chupeta do que de dedo. Em posição de descanso, foi verificado que os músculos periorais estavam em atividade nas crianças com estes tipos de hábito de sucção. Em crianças do grupo controle, ou seja, aquelas que não eram sugadores de dedo, a atividade do lábio e bochecha foi bem menor.

No ano seguinte, Soares \& Totti (1996) relataram as conseqüências no crescimento e desenvolvimento do sistema estomatognático provocados por hábitos deletérios como a sucção de chupeta e digital, entre outras. Os autores 
recomendavam que o hábito de sucção de chupeta fosse removido até os três anos de idade. Uma vez retirado o hábito, a pressão de musculatura perioral restabelece o equilíbrio e os dentes permanentes não são afetados. Nos pacientes com hábito de sucção de chupeta as seguintes características foram observadas: fonação atípica, lábios entreabertos, atresia maxilar, deglutição atípica, língua com posicionamento rebaixado, protrusa e com maior mobilidade dorsal, protrusão dos incisivos superiores, mordida aberta anterior e ou cruzada, palato ogival e musculatura lingual e labial com diminuição da tonicidade.

Dentre as alterações provocadas por sução não nutritiva, pode-se mencionar desenvolvimento de interposição lingual, alteração na fala, incompetência de lábios, interposição labial e alteração na posição de repouso da língua (Adair, 1996) .

Descrevendo a correlação entre a Fonoaudiologia e a Odontologia, Padovan (1996) afirmou que estas duas especialidades devem estar de "mãos dadas" por que a correção ortodôntica será mantida adequadamente somente se a oclusão alcançada ao final do tratamento estiver em harmonia com a musculatura do paciente. Reafirmando, portanto, que a forma e função devem caminhar paralelamente. A autora ressaltou ainda que quanto mais precoce for o tratamento das funções orais do paciente, mais chances este terá de restabelecer suas funções e retornar um desenvolvimento normal. Possibilitando que a função correta seja fixada adequadamente na memória 
neurológica e, desta forma, permitir o amadurecimento neurológico global e das funções orais.

No ano seguinte, Padovan (1997) escreveu sobre o Método Padovan de reorganização neurofuncional. Um método terapêutico miofuncional com o objetivo de reeducar as pressões atípicas exercidas pela língua. Explicou que a mesma neuromusculatura é responsável pelas funções reflexo-vegetativas como respiração, mastigação, deglutição e sucção e pela mímica expressiva, definição dos arcos dentais e fala. Portanto, se há um desvio em alguma destas funções, é muito provável que haja também patologias nas outras funções que são dependentes dos mesmos músculos e dos mesmos impulsos nervosos. A pesquisadora utiliza a chupeta ortodôntica para a realização destes exercícios desde 1972, por acreditar que ela representa o único "exercitador" para a sucção que não deforma os arcos dentais. Os exercícios realizados com estas chupetas podem mudar completamente a mímica expressiva alterada pela hipoou hipertonicidade da musculatura perioral, principalmente. Para restabelecer o tônus muscular, deve existir sinergia e ritmo de contração e relaxamento da musculatura que está sendo trabalhada.

Carvalho (1997) relatou que alterações nas funções de mastigação, deglutição, respiração e sucção podem desencadear distúrbios na fala, musculatura e oclusão dentária. Acredita que a forma do arco dentário depende do equilíbrio entre os tecidos moles que o circundam. Quando uma das diversas funções da boca estão alteradas, as demais também sofrem desvios; portanto, é muito difícil que o paciente apresente um único mau hábito. 
Assim, as crianças que mantém o hábito de chupar chupeta, apresentam maloclusão e hipotensão muscular que leva a uma mastigação deficiente, deglutição atípica e alterações na fala e respiração. Os lábios encontram-se hipotônicos devido a postura adquirida durante a sucção inadequada. A autora mencionou também que na avaliação da criança com mau hábito, devem ser examinadas a deglutição, respiração, sucção, fala e mastigação.

Segundo Cunha et al. (1998), a função básica da sucção é a alimentação; entretanto, ela também pode servir como meio para descarregar tensão e energia e servir como fonte de segurança e prazer. Se for oferecido à criança o sistema de livre demanda, ou seja, aleitamento materno sempre que desejar, a criança não necessitará de outros meios ou artifícios para o estimular a maturação neurofisiológica do sistema estomatognático

Camargo et al. (1998) afirmaram que o uso da chupeta representa perigo para oclusão dependendo do modo como é utilizada, ou seja, a freqüência e tempo de uso. Caso estes sejam prolongados, o hábito é instalado, impedindo contato dos lábios, provocando desvio na direção do crescimento maxilar e ocupando espaço funcional da língua. Todas estas alterações na direção de crescimento, funções da língua e falta de vedamento labial podem acarretar a instalação de maloclusões até mesmo na fase de rodetes gengivais. Desta maneira, a modelagem das bases ósseas e o crescimento apresentam direção e formas desviadas dos padrões normais de crescimento e desenvolvimento. Até os $6-7$ meses de vida, o bebê apresenta três funções extremamente importantes: sucção, deglutição e respiração. A sucção é um 
reflexo natural e o primeiro da alimentação. No lactente, os objetivos da sucção são nutrição e satisfação psicoemocional; além de exercitar toda a musculatura facial e estimular o posicionamento anterior da mandíbula. Os exercícios realizados durante a sucção, fortalecem os músculos, alongam fibras do orbicular dos lábios e proporcionam a coordenação dos atos de sucção e respiração, portanto, a respiração nasal. As duas maiores "fomes" do bebê, são a necessidade de sentir-se alimentado e a de realizar sucção. Satisfazer estas duas condições de maneira equilibrada e simultânea seria o ideal. Ao receber aleitamento materno, o bebê tem sua necessidade de sucção satisfeita antes da repleção gástrica. Já no caso do aleitamento artificial realizado de maneira incorreta, há um grande fluxo de leite e assim o bebê sente-se alimentado antes de ter sua necessidade de sucção saciada.

As autoras aconselham que as mães sejam orientadas a reconhecer quando o choro do bebê é decorrente da falta de sucção. Nestes casos é descrita uma técnica para estimular e satisfazer a função de sucção do bebê. Assim, as pesquisadoras orientam os pais que a chupeta deve ser utilizada apenas como aparelho para realizar exercícios de sucção; e não para acalmar o choro devido a outros motivos como cólica, susto, desconforto, solidão ou consolo. Descreveram também, as características da chupeta mais adequada. Esta deve ser de preferência ortodôntica, com base do bico mais achatado, o que evita um distanciamento maior dos lábios e a inclinação do bico para cima permitindo um melhor posicionamento da língua. Outra característica importante é o apoio labial, que deve ser ligeiramente curvo e voltado para a boca, 
ajustando-se ao contorno dos lábios. Este apoio deve ser recortado na parte próxima ao nariz, para permitir um bom vedamento e respeitar a anatomia do local. Dois furos de ventilação, no mínimo, são necessários. A presença da argola não é necessária. Apenas uma saliência para permitir que a mãe puxe a chupeta é suficiente. Vale ressaltar que o uso de fitas, correntes ou cordões para amarrar a chupeta podem promover a asfixia da criança. As autoras concluem que o uso de chupeta, desde que de maneira racional, ou seja, como aparelho de sucção, pode ser benéfica. (Camargo et al. ,1998)

Camargo (1998) explicou que a utilidade da chupeta é de ser um complemento da sucção, ou seja, para saciar a necessidade fisiológica da sucção, e nunca para acalmar o choro da criança e distraí-la. A chupeta não deve ser utilizada como consolo; mas apenas em pequenos intervalos, para complementar a sucção. A autora enfatizou que a chupeta deve ser utiliza apenas como "aparelho" para exercícios de sucção. Utilizando-a de maneira racional, o hábito não se instalará e a possibilidade de chupar o dedo é reduzida. O bebê apresenta as sensações de fome e necessidade de sucção praticamente simultaneamente, e estas fazem parte do desenvolvimento e alimentação do bebê. A prática ideal é satisfazer a fome e a suç̧ão simultaneamente, ou seja, recebendo aleitamento materno. Mesmo tendo mamado no seio materno, a criança poder não ter tido satisfeita plenamente sua necessidade de sucção. A criança chora e acorda e a mãe não sabe se a criança está com fome ou necessita apenas de satisfazer a sucção. A autora orienta que com o simples ato de tocar o contorno dos lábios da crianças com o 
bico da chupeta, dá para saber se a criança esta necessitando de sucção. Caso seja afirmativo, ela desencadeará os movimentos de sucção. Alertou ainda, que se a chupeta permanecer interposta entre os lábios, haverá perda da propiocepção de contato labial, interposição da língua e até respiração incorreta em alguns casos. É muito importante que o bebê não perca a "memória" muscular do contato entre os lábios e de manter a boca fechada.

Segundo Sies \& Carvalho (1998) a sucção é um reflexo primitivo importantíssimo para a sobrevivência da criança e está presente em todas as crianças normais até os 4 anos de idade. No período entre o quarto e sétimo mês de vida, há uma redução na apresentação deste reflexo, o qual pode desaparecer até o final do primeiro ano de vida. O reflexo de sucção é considerado neurofuncionalmente desnecessário a partir do sexto ou sétimo mês de vida. Mencionam também, que este mantém-se presente até a idade em a criança apresente suas estruturas neuromusculares maduras e adaptadas aos movimentos de comer e beber coordenadamente. A função de sucção deve ser gradativamente substituída pela de mastigação, proporcionando um estímulo mais correto das estruturas bucofaciais.

Modesto et al. (1999) avaliaram o nível de conhecimento de 180 mães sobre o uso e as características das chupetas que ofereciam aos seus filhos. Os autores verificaram que $87.8 \%$ das mães acreditavam que o uso da chupeta poderia provocar algum tipo de alteração no arcos dentais. A maioria $(83,7 \%)$ das entrevistadas relatou que a chupeta servia para acalmar a criança, $42,9 \%$ ofereceu-a por qualquer motivo e $28,6 \%$ sempre que a criança chorava. 
Mais da metade das mães $(65,3 \%)$ afirmou que seus filhos usavam a chupeta dia e noite e $71.4 \%$ que as crianças dormiam com a chupeta ànoite. Como mencionado anteriormente, os autores propuseram a denominação de chupeta anatômica em vez de ortodôntica para aquela mais satisfatória, para evitar o mau entendimento do termo ortodôntico pelos pais. Ressaltaram também que se a chupeta for utilizada com muita freqüência e por tempo prolongado, ela poderá provocar um desvio na direção do crescimento maxilo-mandibular. Isto ocorre por que a chupeta ocupa o espaço funcional da boca, levando a um deslocamento da língua, afastando os lábios e rebordos, e provocando a perda da propiocepção do contato labial dos bebês. Reafirmando o que já foi mencionado, os autores orientam para que a chupeta seja utilizada em casos restritos, para complementar a necessidade de sucção.

Serra-Negra et al. (1999) entrevistaram 156 mães de crianças entre 2 a 12 anos de idade, sobre o uso de chupetas pelos seus filhos. Os autores constataram que a chupeta convencional foi mais freqüente na classe social não favorecida e nas crianças cujas mães tinham baixa escolaridade. Já a anatômica foi mais prevalente na classe favorecida e nas crianças cujas mães tinham alto nível de escolaridade . A maioria (93,6\%) das mães ofereceu a chupeta aos seus filhos pelo seu papel tranquilizador. 


\section{PROPOSIÇÃO}

Este trabalho tem o propósito de verificar:

3.1 As características e relações dos arcos dentais nas crianças que utilizavam chupetas anatômicas (ortodônticas) ou convencionais ou nunca tiveram hábito de sucção de chupeta, comparanda-os;

3.2 As características das estruturas miofuncionais orais em crianças que nunca tiveram hábito de sucção de chupeta ou que utilizavam chupetas anatômicas (ortodônticas) ou convencionais, comparando-as;

3.3 Se existe associação entre o modo como a criança suga a chupeta e as características dos arcos dentais e estruturas miofuncionais orais;

3.4 A relação entre o hábito de sugar a chupeta e o aleitamento materno, uso de mamadeira, aspectos comportamentais da mãe e sexo, idade e número de irmãos da criança;

3.5 Se existe associação entre o uso e tipo de chupeta com a renda familiar e grau de escolaridade materna. 


\section{CASUÍSTICA- MATERIAL E MÉTODOS}

\subsection{Casuística}

Após aprovação do Comitê de Ética em Pesquisa da Faculdade de Odontologia da Universidade de São Paulo, protocolo CEO/OF 203 / 98, foram distribuídos aleatoriamente, 350 questionários æ̀̀ mães de crianças entre 36 e 60 meses de idade de quatro instituições de ensino, públicas e privadas, da cidade de São Paulo, sem distinção de cor, sexo ou raça. Destes retornaram 250. Foram selecionadas para participar do estudo crianças cujas mães assinaram o termo de consentimento livre e esclarecido e responderam o questionário (Apêndice A). As crianças deveriam apresentar as seguintes condições: dentição decídua completa, ausência de anomalias dentárias de número, forma, estrutura ou erupção, ausência de lesões de cárie cavitadas e ausência de qualquer dente permanente erupcionado. Foram selecionadas aquelas com hábito de sucção de chupeta presente, que utilizavam somente a chupeta anatômica (ortodôntica) ou a convencional (Figuras 1 e 2) e aquelas que nunca tiveram este. Foram excluídas todas as crianças com hábito de sucção de dedo presente ou prévio, assim como aquelas que utilizavam chupetas mistas, com bico 
anatômico e escudo convencional ou bico convencional e escudo anatômico. A distribuição das 61 crianças encontra-se na Tabela 4.1.

TABELA 4.1 - Distribuição das freqüências da variável "Uso e tipo de chupeta"

\begin{tabular}{l|c|c}
\hline \multicolumn{1}{c|}{ Uso e tipo de chupeta } & $\mathrm{n}$ & $\%$ \\
\hline Nunca usou & 27 & 44,3 \\
Usa anatômica & 20 & 32,8 \\
Usa convencional & 14 & 22,9 \\
\hline Total & 61 & 100,0 \\
\hline
\end{tabular}

Foi adotada a terminologia "chupeta anatômica" (Figura 1) em vez da "ortodôntica" de acordo com Modesto et al. (1999); e "chupeta convencional" (Figura 2), como utilizado por Turgeon-O’Brien et al. (1996) e Serra-Negra et al. (1999).

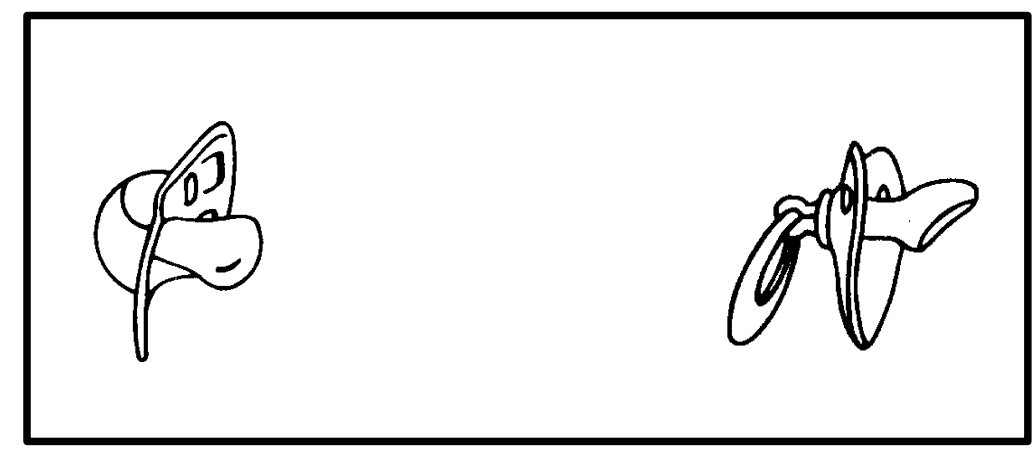

Figura 1 - Esquema dos tipos de chupetas anatômicas 


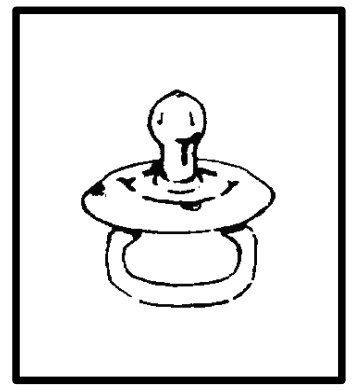

Figura 2 - Esquema da chupeta convencional

\subsection{Material e Métodos}

Esta fase foi dividida em três partes: 1. questionário, 2. avaliação dos arcos dentais e 3. avaliação de estruturas miofuncionais orais.

\subsubsection{Questionário}

O questionário (Apêndice A) continha perguntas fechadas, as quais a mãe respondia selecionando a(s) alternativas(as) que melhor expressasse $(m)$ sua(s) resposta(as), e algumas perguntas abertas. Foram abordadas questões referentes ao aleitamento materno, aleitamento artificial, grau de escolaridade materna, ganho salarial médio da família, número de irmãos da criança, hábito de sucção de chupeta, pré-natal da mãe e suas atitudes na maternidade.

Foi oferecido às mães um espaço em branco, onde elas poderiam escrever dúvidas ou complementar as respostas anteriores. 


\subsubsection{Avaliação dos arcos dentais}

Para esta avaliação, as crianças foram posicionadas, sob luz natural, em cadeira escolar com a cabeça apoiada contra uma parede, com tronco a $90^{\circ}$ em relação as pernas. O exame clínico foi realizado pela própria pesquisadora. Foram utilizados espelhos clínicos planos número 5, réguas metálicas milimetradas de pequeno porte Bioarte ${ }^{\circledR}$, lanterna de mão pequena Duracell ${ }^{\circledR}$ COMPACT LIGHT, compasso Miltex 68-695 (Germany) e ficha para anotação (Apêndice B ).

Todas as características observadas e medidas obtidas foram realizadas com a criança em relação cêntrica ou habitual, sempre com o cuidado de solicitar àcriança que abrisse e fechasse a boca diversas vezes, com o intuito de melhor identificar esta relação e confirmar as características verificadas, conforme descrito por Patrício (1993).

Foram observadas as seguintes características:

a) Tipo de arco

Para a determinação do tipo de arco I ou II (Baume, 1950) foi observado a presença ou ausência de espaços no segmento anterior de canino a canino (Brunner, 1982) tanto no arco inferior quanto no superior . Desta maneira, foi considerado espaço aquele igual ou superior a $0,5 \mathrm{~mm}$ (Parfitt, 1956) e arco tipo I aquele que apresentava espaços generalizados na região anterior superior ou cuja somatória de espaços fosse igual ou maior a 2,5 mm (Brunner, 1982). 
b) Desvio de linha média

Foi adotado a coincidência ou não da linha média entre os incisivos centrais superiores e inferiores. Se não havia coincidência, considerou-se desvio de linha média para a direita ou esquerda, tendo como ponto fixo a linha média entre os incisivos centrais superiores.

c) Espaço primata

Presença de diastema entre o incisivo lateral e canino no arco superior, e entre canino e primeiro molar decíduo no arco inferior (Baume, 1943 apud Baume 1950).

d) Relação terminal dos segundos molares decíduos

Com auxílio da lanterna e espelho clínico avaliou-se a relação terminal dos segundos molares decíduos, segundo critérios de Baume (1950):

i) plano vertical: quando a face distal dos segundos molares decíduos superiores e inferiores apresentavam-se num mesmo plano vertical ou reto;

ii) degrau mesial: quando a face distal dos segundos molares decíduos inferiores posicionava-se mesialmente em relação ao segundo molar decíduo superior;

iii) degrau distal: quando a face distal dos segundos molares decíduos inferiores posicionava-se distalmente em relação ao segundo molar decíduo superior. 
e) Relação canina

A relação canina foi classificada segundo critérios de Foster \& Hamilton (1969):

i) Classe I, nos casos em que a ponta da cúspide do canino superior estava no mesmo plano vertical da face distal do canino inferior;

ii) Classe II, no casos em que a ponta da cúspide do canino superior estava mesialisada em relação a face distal do canino inferior;

iii) Classe III, nos casos em que a ponta da cúspide do canino superior apresentava uma posição distalizada em relação a face distal do canino inferior.

f) Sobremordida

A sobremordida foi considerada como a distância na qual a margem incisal dos dentes superiores ultrapassa verticalmente a margem incisal dos dentes inferiores (Valente \& Mussolino, 1989). A classificação da sobremordida foi realizada de acordo com Adair et al. (1995) sendo determinada como:

i) $50 \%$ ou menos de sobremordida dos incisivos superiores sobre os incisivos inferiores;

ii) mais que $50 \%$ de sobremordida dos incisivos superiores sobre os incisivos inferiores;

iii) mordida aberta anterior; 
iv) topo a topo.

A medição da mordida aberta anterior foi realizada segundo Patrício (1993), posicionando uma das pontas do compasso sobre a borda mesial do incisivo central superior mais protruído e a outra ponta na borda mesial do incisivo central inferior correspondente. O compasso foi levado à régua metálica milimetrada usada nas outras medições, e assim determinada em milímetros a dimensão da mordida aberta anterior.

g) Mordida cruzada posterior

A mordida cruzada posterior foi avaliada segundo Adair et al., 1995. Foi considerada mordida cruzada posterior quando existia uma relação de sobressaliência vestibular inversa dos dentes superiores, de canino a segundo molar decíduo, com os seus antagonistas inferiores.

h) Mordida aberta posterior

A mordida aberta posterior foi determinada como sendo aquela em que não havia nenhum tipo de contato oclusal entre um ou mais dentes posteriores superiores e inferiores, de canino a segundo molares.

i) Sobressaliência

A sobressaliência foi determinada segundo critérios modificados de Brunner (1990). A medição da sobressaliência foi realizada com régua metálica milimetrada de pequeno porte, em milímetros, posicionada de tal maneira na face vestibular de um dos incisivos centrais inferiores para que 
ela ficasse paralela a esta superfície e sua graduação estivesse na borda incisal. A medida da sobressaliência correspondia a distância entre a borda incisal do incisivo central inferior a borda incisal do incisivo central superior. Quando um dos incisivos centrais superiores estava mais protruído que o outro, a medida da sobressaliência era realizada naquele mais protruído.

\section{j) Distâncias intercaninas}

As distâncias intercaninas dos arcos superiores e inferiores foram determinadas de duas formas segundo as referências tomadas: as pontas das cúspides, segundo Bishara et al. (1997), ou ponto cervical mais lingual ou palatino segundo Usberti et al. (1985). Quando a distância intercanina foi medida entre as pontas dos caninos dos arcos superiores e inferiores, e as pontas dos mesmos estavam desgastadas, a largura era medida no centro da área desgastada (Øgaard et al., 1994).

O compasso de ponta seca foi posicionado no ponto de referência dos caninos e transferido àrégua metálica milimetrada.

\subsubsection{Avaliação das estruturas miofuncionais orais}

A avaliação das estruturas miofuncionais orais foi realizada sob luz natural, com a criança sentada em cadeira escolar porém sem apoiar as costas ou cabeça no encosto da cadeira. Esta avaliação consistia em verificar o aspecto e tonicidade das bochechas, língua e lábios, assim como a mobilidade destas duas últimas entidades anatômicas. Foram observados 
também o tipo de palato duro (normal, estreito ou alto) e a simetria facial. $\mathrm{O}$ exame clínico foi realizado por uma única examinadora, fonoaudióloga do Hospital Universitário da Faculdade de Odontologia da Universidade de São Paulo segundo avaliação proposta por Gomes et al. (1993). As observações foram transcritas para ficha clínica (Apêndice C).

\subsubsection{Análise estatística}

As técnicas estatísticas utilizadas foram: 1. Análise descritiva unidimensional e bidimensional, 2. Análise de dados categorizados e 3 . Análise de Variância com efeitos fixos, descritas por Agresti (1990) e Neter et al. (1996) e estão apresentadas por Botter et al. (2000) em relatório de análise estatística.

Os pacotes computacionais utilizados para a Análise Estatística foram: EXCEL for Windows (versão 97), SPSS for Windows (versão 8.0) e WORD for Windows (versão 97).

As análises descritivas foram realizadas para os dados do questionário, assim como uma análise inferencial utilizando os Testes de Independência (Qui-quadrado de Pearson) entre a variável "Usa chupeta" e as variáveis "Sexo", "Renda familiar", "Estudo da mãe”, "Irmãos”, "Término do aleitamento materno exclusiva", "Término do aleitamento materno", "Continua usando mamadeira", "Quantas chupetas no enxoval, "Orientação quanto à chupeta no curso", "Levou chupetas para a maternidade". Foi utilizado o nível de significância de 5\% para todo o estudo. 
Para os dados das avaliações dos arcos dentais e das estruturas miofuncionais orais, foi realizado primeiramente uma análise descritiva discriminando o uso e tipo de chupeta. O Teste de Independência (Quiquadrado de Pearson) foi novamente realizado para as variáveis categorizadas e a Análise de Variância para as não categorizadas, ou seja as quantitativas. Quando era observada uma associação significante (p 0,05), construíram-se intervalos de confiança para as diferenças entre probabilidades para as variáveis categorizadas e intervalos de Bonferroni para as diferenças entre as médias das variáveis quantitativas, para detectar entre quais delas havia diferença (Agresti, 1990; Neter et al., 1996). 


\section{RESULTADOS E DISCUSSÃO}

Como já apresentado na Revisão da Literatura, os hábitos de sucção não nutritivos têm merecido bastante atenção dos pesquisadores, particularmente no que diz respeito às alterações na oclusão. Entretanto, ainda são poucos os trabalhos que comparam os efeitos do uso das chupetas anatômicas com os das convencionais.

Para facilitar a leitura e compreensão dos resultados obtidos, optou-se por dividir esta seção em três partes: 1. questionário, 2. avaliação dos arcos dentais e 3. avaliação das estruturas miofuncionais orais.

\subsection{Questionário}

A idade das crianças avaliadas variou de 36 a 60 meses, sendo a média dos três grupos estudados muito próxima, entre 45,1 meses e 46,1 meses (Tabela 5.1), similares àquela encontrada por Adair et al. (1995) que também não observaram diferença na média de idade dos mesmos grupos avaliados. 
TABELA 5.1 - Estatística descritiva da variável "Idade" (em meses) segundo a variável "Uso e tipo de chupeta"

\begin{tabular}{lcccccc}
\hline $\begin{array}{c}\text { Uso e tipo de } \\
\text { chupeta }\end{array}$ & $\mathrm{n}$ & Média & $\begin{array}{c}\text { Desvio } \\
\text { Padrão }\end{array}$ & Mínimo & Máximo & Mediana \\
\hline Nunca usou & 27 & 46,5 & 7,47 & 36,0 & 60,0 & 45,0 \\
Usa anatômica & 20 & 45,1 & 7,11 & 37,0 & 60,0 & 43,0 \\
Usa convencional & 14 & 46,1 & 6,40 & 39,0 & 59,0 & 44,5 \\
\hline TOTAL & 61 & 46,0 & 7,03 & 36,0 & 60,0 & 44,0 \\
\hline
\end{tabular}

Verificou-se que praticamente a totalidade $(95,1 \%)$ das crianças participantes deste estudo estava na faixa etária entre 3 e 4 anos. Observouse uma freqüência menor do uso de chupeta com o aumento da faixa etária, sendo de $65,6 \%, 29,5 \%$ e $4,9 \%$ aos 3,4 e 5 anos de idade (Tabela 5.2), confirmando os resultados encontrados por Larsson, 1971; Myllärniemi, 1973; Ravn, 1974; Zadik et al., 1977; Farsi et al., 1997; Vadiakas et al., 1998, que também observaram este declínio.

TABELA 5.2 - Distribuição das freqüências da variável "Idade" (anos completos) segundo a variável "Uso e tipo de chupeta"

\begin{tabular}{|c|c|c|c|c|c|c|c|c|}
\hline Idade & \multicolumn{2}{|c|}{3 anos } & \multicolumn{2}{|c|}{4 anos } & \multicolumn{2}{|c|}{5 anos } & \multicolumn{2}{|c|}{ Total } \\
\hline uso de chupeta & $\%$ & $\mathrm{n}$ & $\%$ & $\mathrm{n}$ & $\%$ & $\mathrm{n}$ & $\%$ & $\mathrm{n}$ \\
\hline Nunca usou & 55,6 & 15 & 37,0 & 10 & 7,4 & 2 & 100 & 27 \\
\hline Usa anatômica & 75,0 & 15 & 20,0 & 4 & 5,0 & 1 & 100 & 20 \\
\hline Usa convencional & 71,4 & 10 & 28,6 & 4 & 0,0 & 0 & 100 & 14 \\
\hline Total & 65,6 & 40 & 29,5 & 18 & 4,9 & 3 & 100 & 61 \\
\hline
\end{tabular}


A maioria das crianças era do sexo masculino $(60,7 \%)$ (Figura 3). Pode-se observar pela Figura 4, que no grupo da chupeta convencional, houve uma freqüência elevada de meninos $(71,4 \%)$ em comparação com os outros dois grupos, porém não houve relação estatisticamente significante entre o sexo da criança e o fato de usar ou não chupeta $(p=1,000)$ (Tabela 5.4), concordando com os resultados obtidos por Adair et al. (1995) e Farsi et al. (1997).

Já Myllärniemi (1973) e Larsson (1975) encontraram que o hábito de sucção de chupeta foi mais freqüente nas meninas.

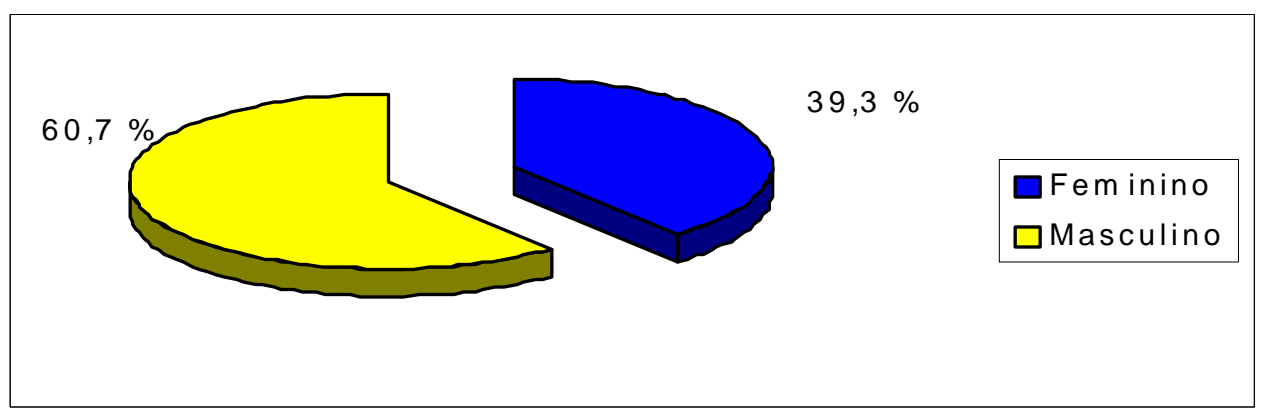

Figura 3 - Distribuição das crianças segundo o sexo

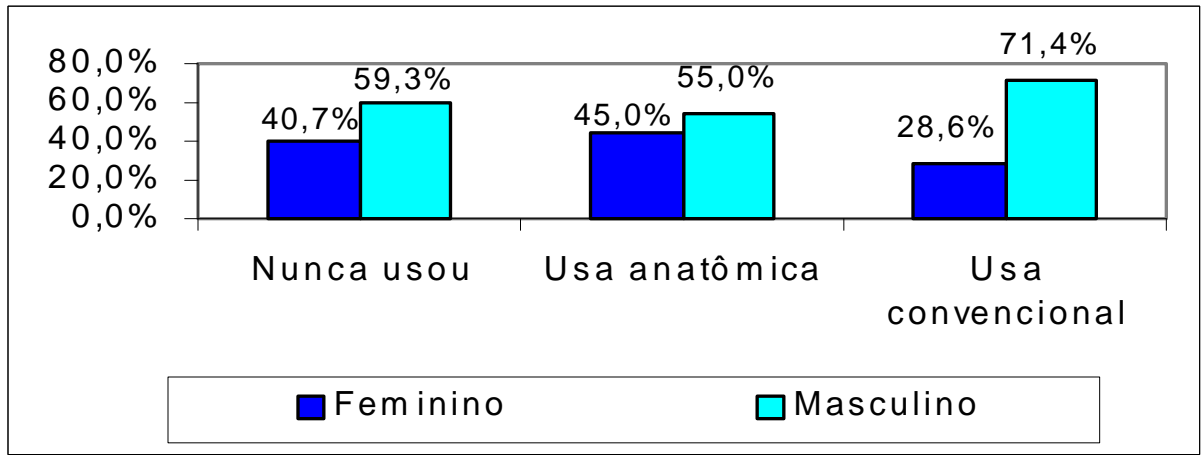

Figura 4 - Distribuição da freqüência relativa do tipo de chupeta segundo o sexo 
A maioria das crianças vivia em famílias cuja renda era inferior a 7 salários mínimos (74,1\%) e cuja escolaridade materna ia até o primeiro ou segundo grau (Tabela 5.3). Houve uma associação estatisticamente significante $(p=0,000)$ entre $\circ$ grau de escolaridade da mãe com a renda familiar (Anexo A) pois todas as mães com nível superior, apresentaram renda familiar acima de 7 salários mínimos, enquanto apenas $7,1 \%$ das mães com escolaridade do ensino fundamental e 6,7\% com estudo médio apresentaram renda acima deste valor.

TABELA 5.3 - Distribuição das freqüências da variável "Renda familiar" (números de salários mínimos) segundo a variável "Escolaridade materna"

\begin{tabular}{|c|c|c|c|c|c|c|c|c|c|c|}
\hline \multirow{2}{*}{$\begin{array}{l}\text { Estudo mãe } \\
\text { Não estudou }\end{array}$} & \multicolumn{2}{|c|}{$\begin{array}{l}1 \mid-3 \text { sal. } \\
\% \quad n\end{array}$} & \multicolumn{2}{|c|}{$\begin{array}{l}3 \mid-5 \text { sal. } \\
\%\end{array}$} & \multicolumn{2}{|c|}{$\begin{array}{l}5 \mid-7 \text { sal. } \\
\%\end{array}$} & \multicolumn{2}{|c|}{$\begin{array}{l}\text { Mais que } 7 \\
\quad \text { sal. }\end{array}$} & \multicolumn{2}{|c|}{$\%^{\text {Total }}$} \\
\hline & 100,0 & 2 & 0,0 & 0 & 0,0 & 0 & 0,0 & 0 & 100,0 & 2 \\
\hline Primeiro grau & 53,6 & 15 & 25,0 & 7 & 14,3 & 4 & 7,1 & 2 & 100,0 & 28 \\
\hline Segundo grau & 33,3 & 5 & 53,3 & 8 & 6,7 & 1 & 6,7 & 1 & 100,0 & 15 \\
\hline Superior & 0,0 & 0 & 0,0 & 0 & 10,0 & 1 & 90,0 & 9 & 100,0 & 10 \\
\hline Pós-graduação & 0,0 & 0 & 0,0 & 0 & 0,0 & 0 & 100,0 & 3 & 100,0 & 3 \\
\hline Total & 37,9 & 22 & 25,9 & 15 & 10,3 & 6 & 25,9 & 15 & 100,0 & 58 \\
\hline
\end{tabular}

Foram avaliadas diversas variáveis obtidas por meio do questionário e o fato de usar ou não a chupeta. As variáveis analisadas foram: sexo da criança, renda familiar, estudo da mãe, número de irmãos da criança, término do aleitamento materno exclusivo, término do aleitamento 
materno , a presença de chupetas já no enxoval da criança, orientação da mãe quanto ao uso de chupeta em cursos ou pré-natal e o ato de ter levar as chupetas para maternidade.

A Tabela 5.4 mostra os Testes de Independência (Qui-quadrado de Pearson) para algumas variáveis em relação ao uso da chupeta.

TABELA 5.4 - Testes de Independência (Qui-quadrado de Pearson) entre a variável "Usa chupeta" e as variáveis "Sexo", "Renda familiar", "Estudo da mãe", "Irmãos", "Término do aleitamento materno exclusivo", "Término do aleitamento materno", "Continua usando mamadeira", "Quantas chupetas no enxoval, "Orientação quanto àchupeta no curso", "Levou chupetas para a maternidade"

\begin{tabular}{|c|c|c|}
\hline Variável do questionário & $\begin{array}{c}\text { Valor da } \\
\text { estatística Qui- } \\
\text { quadrado de } \\
\text { Pearson }\end{array}$ & $\begin{array}{c}\text { Nível } \\
\text { descritivo } \\
\text { exato } \\
\end{array}$ \\
\hline Sexo & 0,040 & 1,000 \\
\hline Renda familiar & 0,243 & 0,962 \\
\hline Estudo da mãe & 5,893 & 0,219 \\
\hline Irmãos & 2,700 & 0,300 \\
\hline $\begin{array}{l}\text { Término do aleitamento materno } \\
\text { exclusivo }\end{array}$ & 9,637 & 0,047 \\
\hline Término do aleitamento materno & 21,282 & 0,000 \\
\hline Continua usando mamadeira & 0,759 & 0,384 \\
\hline Quantas chupetas no enxoval & 7,134 & 0,033 \\
\hline Orientação quanto àchupeta no curso & 0,435 & 0,907 \\
\hline Levou chupetas para a maternidade & 1,588 & 0,261 \\
\hline
\end{tabular}

Pode-se observar que dentre estas variáveis, somente três tiveram correlação estatisticamente significante com o uso da chupeta: o 
término do aleitamento materno exclusivo $(p=0,047)$, término do aleitamento materno $(p=0,000)$ e o fato de ter tido chupetas no enxoval $(p=0,033)$.

Observou-se que não houve relação estatisticamente significante entre o uso ou não da chupeta com as variáveis "Renda familiar", "Estudo da mãe", "Número de irmãos", "Uso da mamadeira", "Sexo" da criança e "ter levado as chupetas para a maternidade" (Tabela 5.4).

O presente estudo está de acordo com Paunio et al. (1993), que não verificaram diferença no nível sócio-econômico entre as mães das crianças que tinham o hábito de sugar chupeta e aquelas sem o hábito instalado. Farsi et al. (1997) também não encontraram relação significante entre a renda familiar e o hábito de sucção da chupeta; mas, encontraram uma associação muito significante $(p<0,05$ e $p<0,01)$ entre o grau de instrução do pai e da mãe, respectivamente. Quanto maior o grau de escolaridade formal, maior a prevalência de hábito de sucção de chupeta.

Larsson (1975) constatou que o hábito de sucção de chupeta foi mais comum em famílias cujos trabalhos exigiam menor nível de educação teórica. Da mesma maneira, Marigo \& Frauches (1993) verificaram que o hábito de sucção de chupeta foi mais freqüente no nível sócio-econômico mais baixo.

Nossos resultados confirmaram aqueles encontrados por Farsi et al. (1997) e Coletti \& Bartholemeu (1998) que também não verificaram diferença no hábito de sucção da chupeta entre as crianças que tinham irmãos ou não.

Igualmente não foi encontrada correlação significante entre a renda familiar e o estudo da mãe como uso e tipo de chupeta utilizada pela 
criança $(p=0,984$ e $p=0,146$ (Anexo A). Contudo, houve uma certa tendência neste sentido. $\mathrm{O}$ uso da chupeta anatômica foi mais freqüente nas crianças cujas mães tinham nível superior de ensino, e a convencional naquelas cujo grau de escolaridade materna era mais baixo que o ensino superior (Tabela 5.5).

Nossos resultados estão de acordo com Paunio et al. (1993) os quais não encontraram diferença entre o nível sócio-econômico das mães das crianças que usavam chupeta e daquelas sem este hábito.

TABELA 5.5 - Distribuição das freqüências da variável "Uso e tipo de chupeta" segundo a variável "Estudo da mãe"

\begin{tabular}{l|c|c|c|c|c|c|c|c}
\hline $\begin{array}{r}\text { Uso e tipo de } \\
\text { chupeta }\end{array}$ & \multicolumn{2}{|c|}{$\begin{array}{c}\text { Nunca usou } \\
\text { Estudo mãe }\end{array}$} & \multicolumn{2}{c|}{$\begin{array}{c}\text { Usa } \\
\text { anatômica }\end{array}$} & \multicolumn{2}{|c|}{$\begin{array}{c}\text { Usa } \\
\%\end{array}$} & \multicolumn{2}{|c}{} \\
\hline Não estudou & 0,0 & 0 & 100,0 & 2 & 0,0 & 0 & 100,0 & 2 \\
Primeiro grau & 48,3 & 14 & 27,6 & 8 & 24,1 & 7 & 100,0 & 29 \\
Segundo grau & 37,5 & 6 & 25,0 & 4 & 37,5 & 6 & 100,0 & 16 \\
Superior & 40,0 & 4 & 50,0 & 5 & 10,0 & 1 & 100,0 & 10 \\
Pós graduação & 100,0 & 3 & 0,0 & 0 & 0,0 & 0 & 100,0 & 3 \\
\hline Total & 45,0 & 27 & 31,7 & 19 & 23,3 & 14 & 100,0 & 60 \\
\hline
\end{tabular}

Obs.: Ocorreu 1 não-resposta

Estes resultados foram diferentes daqueles observados por SerraNegra et al. (1999), que verificaram que a chupeta anatômica foi mais prevalente no grupo de crianças de classe social favorecida $(68,5 \%)$ e cuja 
escolaridade materna era alta, e a convencional no grupo de crianças de classe social não favorecida $(66,7 \%)$ e baixa escolaridade materna.

Atualmente existem no mercado inúmeros tipos de chupetas quanto `a forma (anatômica ou convencional), procedência (importadas ou nacionais) e material (silicone ou látex). É grande também a variação de preços destes artifícios. A convencional nacional é a mais barata; pelo dobro do preço, pode-se adquirir uma anatômica nacional e pelo dobro desta última, adquirisse uma anatômica importada de boa qualidade e procedência. Em um mesmo modelo de chupeta, as de látex são mais baratas do que as de silicone. Segundo Moreira (1998) as de silicone são mais higiênicas devido a sua polidez e transparência.

Mesmo com esta diferença de valores, não foi encontrada no presente estudo correlação entre o tipo de chupeta que a criança sugava e a renda familiar. Isto talvez possa ser explicado pelos critérios utilizados pelas mães na hora de comprar a chupeta. Segundo Modesto et al. (1999), as mães levavam em conta o formato, as cores, a quantidade de enfeites e o preço ao adquirir as chupetas.

No estudo de Serra-Negra et al. (1999), a maioria (78\%) das mães não soube definir o motivo da escolha entre as chupetas convencionais e as anatômicas. Por outro lado, $23 \%$ das mães que escolheram a chupeta anatômica, responderam que adquiriram este modelo por serem decoradas com motivos infantis e mais coloridas que as convencionais, e somente $15 \%$ afirmaram que esta provocaria menor dano ao arco dental. 
Observa-se nestas afirmações que a estética do produto foi mais importante ou predominante quando da escolha do tipo de chupeta. Isto pode explicar também, o motivo pelo qual houve uma freqüência maior de meninos no grupo da chupeta convencional do que no da anatômica (Figura 4). A maioria das chupetas convencionais nacionais são de cor única e sem desenhos infantis, enquanto as anatômicas são mais enfeitadas, coloridas e alegres;, tornando-as, portanto, mais atrativas. As chupetas anatômicas nacionais são facilmente encontradas em supermercados e drogarias em geral, já as importadas estão presentes em alguns supermercados e drogarias e em lojas de artigos para crianças.

Em relação as marcas das chupetas, a Tabela 5.6 mostra que mais da metade $(53,6 \%)$ das crianças com hábito de sucção de chupeta usava as nacionais da marca Lillo ${ }^{\circledR}$ ou Kuka ${ }^{\circledR}$ e 17,9\% a importada NUK ${ }^{\mathrm{TM}}$. Quanto ao material do bico da chupeta, o mais freqüente foi o de látex $(53,1 \%)$ (Tabela 5.7).

TABELA 5.6 - Distribuição das freqüências da variável "Marca da chupeta"

\begin{tabular}{l|c|c}
\hline \multicolumn{1}{c|}{ Marca da chupeta } & $\mathrm{n}$ & $\%$ \\
\hline Lillo® & 8 & 28,6 \\
Kuka® & 7 & 25,0 \\
Nuk $^{\mathrm{TM}}$ & 5 & 17,9 \\
Outro & 7 & 25,0 \\
Qualquer uma & 1 & 3,6 \\
\hline Total & 28 & 100,0 \\
\hline
\end{tabular}

Obs.: Ocorreram 6 não-respostas 
TABELA 5.7 - Distribuição das freqüências da variável "Material da chupeta"

\begin{tabular}{l|c|c}
\hline \multicolumn{1}{c|}{ Material chupeta } & $\mathrm{n}$ & $\%$ \\
\hline Silicone & 8 & $25,0 \%$ \\
Látex & 17 & $53,1 \%$ \\
Ambos & 7 & $21,9 \%$ \\
\hline Total & 32 & $100,0 \%$ \\
\hline
\end{tabular}

Obs.: Ocorreram 2 não-respostas

Existe uma certa tendência em acreditar que a duração do aleitamento materno pode influenciar o desenvolvimento de hábitos de sucção não nutritivos, e, neste estudo observou-se ter ocorrido correlação estatisticamente significante entre o término do aleitamento materno $(p=0,000)$ e $\circ$ aleitamento materno exclusivo $(p=0,047)$ com o uso da chupeta. Portanto, conhecer os padrões e as características das crianças avaliadas e atitudes maternas quanto a esta prática é muito importante. A maioria das mães $(98,2 \%)$ iniciou o aleitamento materno no nascimento ou nos primeiros dias de vida da criança (Anexo A) e apenas um quarto $(25,9 \%)$ realizou o aleitamento materno exclusivo até o quinto ou sexto mês de vida da criança (Figura 5). Duas mães relataram que nunca aleitaram por terem adotado as crianças e uma por problema de saúde. 


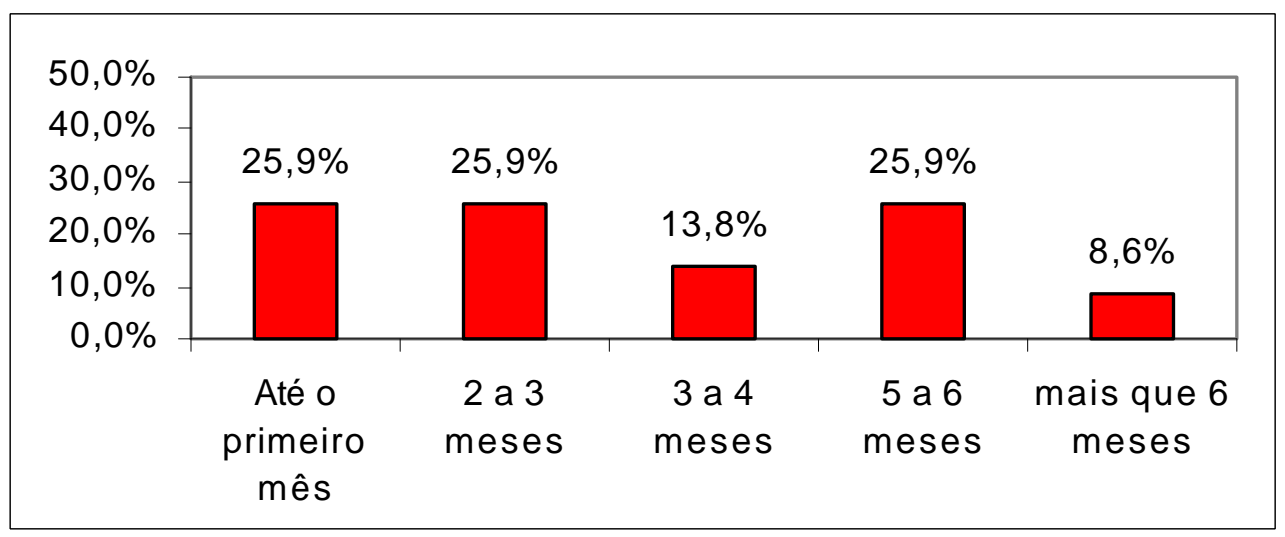

Figura 5 - Distribuição da freqüência relativa da variável "Idade que terminou o aleitamento materno exclusivo", em meses

Ao associar o fato de usar ou não a chupeta com o término do aleitamento materno exclusivo (Tabela 5.8), pôde-se observar que, das crianças que receberam aleitamento materno exclusivo até o primeiro mês de vida, 80,0\% apresentavam hábito de sucção de chupeta. Daquelas que receberam este tipo de aleitamento até praticamente o quinto mês, 25,0\% sugavam chupeta. Por outro lado, o aleitamento materno exclusivo superior aos 6 meses de idade, parece que também esteve associado ao hábito de sucção da chupeta, pois $60,0 \%$ das crianças que receberam aleitamento materno exclusivo prolongado apresentavam hábito de sucção de chupeta.

Vadiakas et al. (1998) observaram que $81 \%$ das crianças examinadas receberam aleitamento materno até pelo menos o primeiro mês de vida e que a média de duração desta prática foi de 4,2 meses. 
TABELA 5.8 - Distribuição das freqüências da variável "Usa chupeta" segundo a variável "Término do aleitamento materno exclusivo"

\begin{tabular}{|c|c|c|c|c|c|c|}
\hline \multirow{2}{*}{$\begin{array}{l}\text { Término do } \\
\text { aleitamento exclusivo }\end{array}$} & \multicolumn{2}{|c|}{ Sim } & \multicolumn{2}{|c|}{ Não } & \multicolumn{2}{|c|}{ Total } \\
\hline & $\%$ & $\mathrm{n}$ & $\%$ & $\mathrm{n}$ & $\%$ & $\mathrm{n}$ \\
\hline Até o primeiro mês & 80,0 & 12 & 20,0 & 3 & 100,0 & 15 \\
\hline $2 \mid-3$ meses & 60,0 & 9 & 40,0 & 6 & 100,0 & 15 \\
\hline $3 \mid-5$ meses & 25,0 & 2 & 75,0 & 6 & 100,0 & 8 \\
\hline $5 \mid-6$ meses & 33,3 & 5 & 66,7 & 10 & 100,0 & 15 \\
\hline Mais que 6 meses & 60,0 & 3 & 40,0 & 2 & 100,0 & 5 \\
\hline Total & 53,4 & 31 & 46,6 & 27 & 100,0 & 58 \\
\hline
\end{tabular}

Os resultados obtidos mostraram que mais da metade $(82,4 \%)$ das mães tinha cessado o aleitamento materno quando a criança tinha um ano de idade e a minoria $(3,5 \%)$ continuou por período superior aos dois anos de vida (Figura 6).

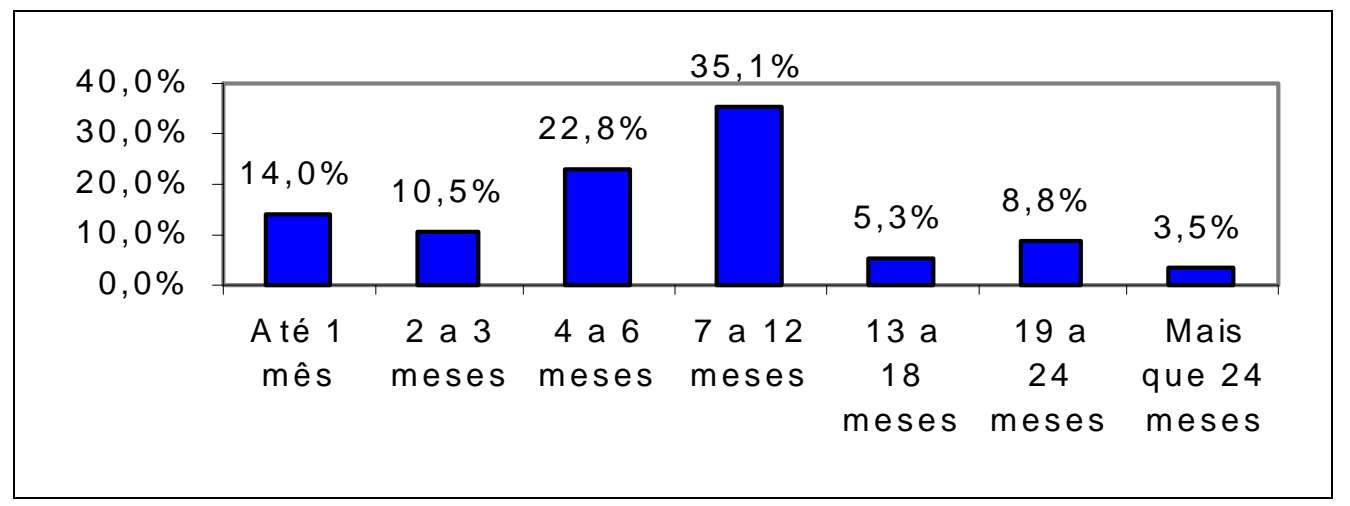

Figura 6 - Distribuição da freqüência relativa da variável "Idade que cessou aleitamento materno", em meses 
A Tabela 5.9 mostra que quando o aleitamento materno não exclusivo foi realizado por período prolongado, acima dos 12 meses, ou menor que 6 meses, houve grande prevalência de hábito de sucção de chupeta. Nos casos em que o aleitamento materno terminou por volta dos 712 meses de idade, houve a menor freqüência $(35,1 \%)$ de crianças com hábito de sucção de chupeta.

TABELA 5.9 - Distribuição das freqüências da variável "Usa chupeta" segundo a variável "Término da aleitamento materno"

\begin{tabular}{l|cc|c|c|c|c}
\hline \multirow{2}{*}{$\begin{array}{l}\text { Término do Uso de chupeta } \\
\text { aleitamento materno }\end{array}$} & \multicolumn{2}{|c|}{ Sim } & \multicolumn{3}{c|}{ Não } & \multicolumn{2}{c}{ Total } \\
\hline Até 1 mês & 87,5 & 7 & 12,5 & 1 & 100,0 & 8 \\
\hline 2 a 3 meses & 100,0 & 6 & 0,0 & 0 & 100,0 & 6 \\
\hline 4 a 6 meses & 69,2 & 9 & 30,8 & 4 & 100,0 & 13 \\
\hline 7 a 12 meses & 35,0 & 7 & 65,0 & 13 & 100,0 & 20 \\
\hline 13 a 18 meses & 66,7 & 2 & 33,3 & 1 & 100,0 & 3 \\
\hline 19 a 24 meses & 0,0 & 0 & 100,0 & 5 & 100,0 & 5 \\
\hline Mais que 24 meses & 0,0 & 0 & 100,0 & 2 & 100,0 & 2 \\
\hline Total & 54,4 & 31 & 45,6 & 26 & 100,0 & 57 \\
\hline Obs.: Ocorreu 1 não-resposta & & & & &
\end{tabular}

Os resultados do presente estudo estão de acordo com vários autores que afirmaram que crianças que recebem aleitamento materno nos primeiros meses apresentam menor chance de desenvolver hábitos bucais 
(Finocchi, 1982; Larsson et al., 1993; Paunio et al., 1993; Gimenez et al., 2000).

A associação entre o tempo de aleitamento materno e a presença de hábitos bucais nocivos também foi relatada por alguns autores; sendo que as crianças que recebem aleitamento materno por um período maior, apresentam uma prevalência menor destes hábitos (Larsson, 1975; Moreira, 1978; Dadalto, 1989; Paunio et al., 1993; Coeli \& Toledo, 1994; Serra-Negra et al., 1997; Ferreira \& Toledo, 1997; Farsi et al., 1997; Coletti \& Bartholomeu, 1998; Forte et al., 2000).

Paunio et al. (1993) constataram que crianças que foram aleitadas no peito por um período inferior a seis meses, apresentaram um risco de 1,7 vezes em desenvolver hábitos de sucção de chupeta aos três anos de idade.

Período de aleitamento abaixo do recomendado, também foi observado por Serra-Negra et al. (1997). Os autores verificaram que as criança que receberam aleitamento materno por um período de até um mês, apresentavam um risco sete vezes maior de desenvolver hábitos bucais deletérios do que aquelas que foram aleitadas até os seis meses, pelo menos.

Robles et al. (1999) relataram que crianças que receberam aleitamento materno abaixo ou acima do período considerado natural por estes autores (entre 4-8 meses), apresentavam hábito de sucção com maior freqüência.

Forte et al. (2000) observaram que quando o aleitamento materno exclusivo foi realizado por períodos maiores que 4 meses, a 
prevalência dos hábitos de sucção não nutritivos foi significantemente menor do que naquelas crianças que receberam aleitamento misto ou artificial.

Nossos resultados são similares a estes, uma vez que foi encontrado uma alta prevalência de hábito de sucção de chupeta nas crianças que receberam aleitamento materno por até 3 meses de idade. Também foi observado que a prevalência do hábito de sugar a chupeta aumentou nas crianças aleitadas até $13-18$ meses.

Por outro lado, Ravn (1974) e Vadiakas et al. (1998) não encontraram uma associação significante entre a prática do aleitamento materno com hábitos de sucção. Vadiakas et al. (1998) observaram somente uma tendência da prevalência da sucção de chupeta diminuir com o aumento no período de aleitamento materno.

Não houve relação estatisticamente significante entre o término do aleitamento materno exclusivo com a renda familiar ou grau de estudo da mãe, $p=0,722$ e $p=0,791$, respectivamente (Anexo $A)$.

Ao iniciar o desmame, uma das maneiras mais disseminadas para administrar líquidos a criança é o uso da mamadeira. Ela é amplamente utilizada pela população; e as crianças que participaram deste estudo não fugiram da regra, pois, $96,7 \%$ delas já usaram ou ainda usavam a mamadeira (Anexo A). Em praticamente metade das crianças $(44,1 \%)$, a mamadeira foi introduzida nos primeiros três meses após o nascimento (Figura 7) e uma parte expressiva das crianças $(63,8 \%)$ ainda utilizava a mamadeira até o momento da avaliação (Figura 8). 
Não houve correlação significante entre o tempo de uso da mamadeira, com a renda familiar $(p=0,242)$ ou grau de escolaridade materna $(p=0,205)($ Anexo A).

Vadiakas et al. (1998) verificaram que 50\% das crianças de 4 anos de idade e $44 \%$ das de 5 anos de idade examinadas, utilizaram a mamadeira por um período maior que 36 meses.

Nos estudos de Larsson et al. (1993) e Vadiakas et al. (1998), o período do aleitamento também foi associado ao uso da mamadeira, apresentando uma relação inversa.

Robles et al. (1999) relataram que crianças que receberam aleitamento materno abaixo ou acima do período considerado natural (entre 4 - 8 meses), apresentavam maior freqüência também do uso da mamadeira além dos dois anos de idade.

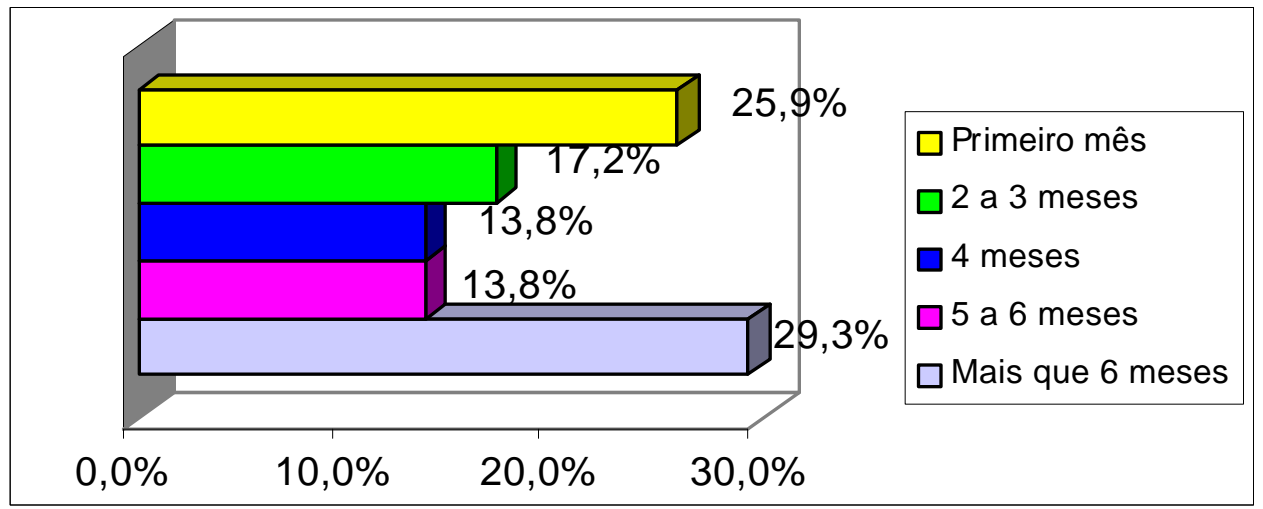

Figura 7 - Distribuição da freqüência relativa da variável "Início uso da mamadeira“, em meses 


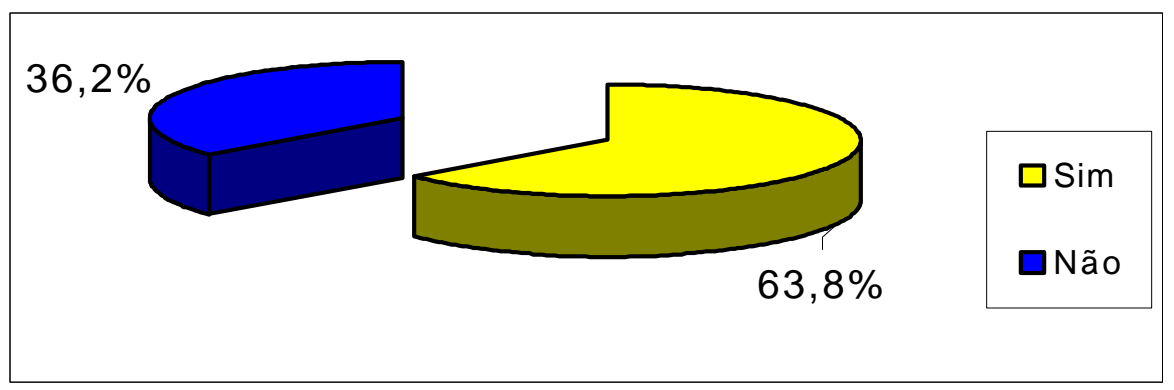

Figura 8 - Distribuição da freqüência relativa da variável "Continua usando mamadeira"

Quanto ao formato do bico da mamadeira utilizado pela criança, anatômico ou convencional, a Tabela 5.10 mostra que houve uma relação significante com a renda familiar $(p=0,033)$ e grau de estudo formal da mãe ( $p=0,073)$ (tendo como nível de significância 10\%).

TABELA 5.10 - Testes de Independência entre as variáveis "Renda familiar" e "Grau de estudo da mãe" com o "Formato do bico da mamadeira"

\begin{tabular}{lcc}
\hline Variável do questionário & $\begin{array}{c}\text { Valor da estatística Qui- } \\
\text { quadrado de Pearson }\end{array}$ & $\begin{array}{c}\text { Nescritivo } \\
\text { exato }(p)\end{array}$ \\
\hline Renda familiar & 12,758 & $0,033^{*}$ \\
Grau de estudo da mãe & $18 ., 584$ & 0,073 \\
\hline
\end{tabular}

* Estatisticamente significante

O formato do bico de mamadeira chamado de ortodôntico ou anatômico foi mais utilizado por crianças de famílias com renda familiar acima de cinco salários mínimos, e o chamado convencional por $100 \%$ das crianças de famílias com até 5 salários mínimos (Tabela 5.11). A maioria 
das crianças cujas mães tinham grau de escolaridade até o segundo grau, utilizava bico de mamadeira com formato convencional. Houve uma tendência do bico ortodôntico ou anatômico ter sido utilizado com maior freqüência entre as crianças cujas mães apresentam grau de instrução superior (Tabela 5.12).

TABELA 5.11 - Distribuição das freqüências da variável "Formato do bico da mamadeira utilizado " segundo a variável "Renda familiar"

\begin{tabular}{|c|c|c|c|c|c|c|c|c|}
\hline \multirow[t]{2}{*}{$\begin{array}{c}\text { Formato do } \\
\text { bico da } \\
\text { mamadeira } \\
\text { utilizado }\end{array}$} & \multirow{2}{*}{\multicolumn{2}{|c|}{$\begin{array}{l}\text { Anatômico } \\
\%\end{array}$}} & \multicolumn{2}{|c|}{ Convencional } & \multicolumn{2}{|c|}{ Ambos } & \multicolumn{2}{|c|}{ Total } \\
\hline & & & & & & $\mathrm{n}$ & & $\mathrm{n}$ \\
\hline $1 \mid-3$ sal. & 0,0 & 0 & 100,0 & 18 & 0,0 & 0 & 100,0 & 18 \\
\hline $3 \mid-5$ sal. & 0,0 & 0 & 100,0 & 14 & 0,0 & 0 & 100,0 & 14 \\
\hline $5 \mid-7$ sal. & 16,7 & 1 & 83,3 & 5 & 0,0 & 0 & 100,0 & 6 \\
\hline mais que 7 sal. & 28,6 & 4 & 64,3 & 9 & 7,1 & 1 & 100,0 & 14 \\
\hline Total & 9,6 & 5 & 88,5 & 46 & 1,9 & 1 & 100,0 & 52 \\
\hline
\end{tabular}

TABELA 5.12 - Distribuição das freqüências da variável "Formato do bico da mamadeira utilizado" segundo a variável "Estudo da mãe"

\begin{tabular}{|c|c|c|c|c|c|c|c|c|}
\hline $\begin{array}{r}\text { Formato do bico } \\
\text { da mamadeira } \\
\text { utilizado }\end{array}$ & Anat & nico & Conve & ciona & & & To & \\
\hline Estudo mãe & & $\mathrm{n}$ & & $\mathrm{n}$ & $\%$ & $\mathrm{n}$ & & $\mathrm{n}$ \\
\hline Não estudou & 0,0 & 0 & 100,0 & 1 & 0,0 & 0 & 100,0 & 1 \\
\hline Primeiro grau & 3,8 & 10 & 96,2 & 16 & 0,0 & 0 & 100,0 & 26 \\
\hline Segundo grau & 0,0 & 0 & 93,3 & 14 & 6,7 & 1 & 100,0 & 15 \\
\hline Superior & 22,2 & 2 & 77,8 & 7 & 0,0 & 0 & 100,0 & 9 \\
\hline Pós graduação & 66,7 & 2 & 33,3 & 1 & 0,0 & 0 & 100,0 & 3 \\
\hline Total & 9,3 & 5 & 88,9 & 39 & 1,9 & 10 & 100,0 & 54 \\
\hline
\end{tabular}


Atualmente existem no mercado apenas uma marca de bico de mamadeira anatômico nacional $\left(\right.$ Kuka $\left.^{\circledR}\right)$ e os restantes são o importados, e não estão disponíveis com tanta facilidade quanto `as chupetas anatômicas importadas ou nacionais. Portanto, deve-se saber que eles existem para serem comprados e, provavelmente, somente aquelas mães com nível econômico e cultural mais favorecido, tenham a oportunidade de conhecer e adquirir este tipo de bico. O uso do bico de mamadeira convencional foi mais freqüente $(89,1 \%)$ do que o anatômico (Tabela 5.13); quanto ao material, o de silicone (54,9\%) foi o mais comum (Tabela 5.14). A maioria $(57,1 \%)$ dos bicos era nacional, das marcas Lillo® ou Kuka® (Tabela 5.15).

TABELA 5.13 - Distribuição das freqüências da variável "Formato do bico da mamadeira utilizado"

\begin{tabular}{l|c|c}
\hline \multicolumn{1}{c|}{$\begin{array}{c}\text { Formato do bico da } \\
\text { mamadeira utilizado }\end{array}$} & $\mathrm{n}$ & $\%$ \\
\hline Anatômico & 5 & $9,1 \%$ \\
Convencional & 49 & $89,1 \%$ \\
Ambos & 1 & $1,8 \%$ \\
\hline Total & 55 & $100,0 \%$ \\
\hline
\end{tabular}

Obs.: Ocorreram 4 não-respostas

TABELA 5.14 - Distribuição das freqüências da variável "Material do bico da mamadeira utilizado"

\begin{tabular}{|c|c|c|}
\hline $\begin{array}{l}\text { Material do bico da } \\
\text { mamadeira utilizado }\end{array}$ & $\mathrm{n}$ & $\%$ \\
\hline Silicone & 28 & $54,9 \%$ \\
\hline Látex & 17 & $33,3 \%$ \\
\hline Ambos & 6 & $11,8 \%$ \\
\hline Total & 51 & $100,0 \%$ \\
\hline
\end{tabular}

Obs.: Ocorreram 8 não-respostas 
TABELA 5.15 - Distribuição das freqüências da variável "Marca do bico da mamadeira utilizado"

\begin{tabular}{l|c|c}
\hline $\begin{array}{l}\text { Marca do bico da } \\
\text { mamadeira utilizado }\end{array}$ & $\mathrm{n}$ & $\%$ \\
\hline Lillo ${ }^{\circledR}$ & 19 & $45,2 \%$ \\
Kuka & 5 & $11,9 \%$ \\
Nuk & & \\
Outro & 3 & $7,1 \%$ \\
\hline Total & 42 & $35,7 \%$ \\
\hline
\end{tabular}

Obs.: Ocorreram 17 não-respostas

Houve uma certa relação entre o uso de chupeta e o uso de mamadeira. Na Tabela 5.16 pode ser visto que $59,5 \%$ das crianças que ainda utilizavam a mamadeira até o momento da avaliação apresentavam o hábito de sucção de chupeta. Isto é uma evidência de que as crianças que usam mamadeira por período prolongado, tendem a usar a chupeta também por bastante tempo.

TABELA 5.16 - Distribuição das freqüências da variável "Usa chupeta" segundo a variável "Continua usando mamadeira"

\begin{tabular}{l|cc|c|c|c|c}
\hline \multicolumn{2}{r|}{$\begin{array}{l}\text { Uso de } \\
\text { chupeta }\end{array}$} & \multicolumn{2}{|c|}{ Sim } & \multicolumn{2}{c|}{ Não } & \multicolumn{2}{c}{ Total } \\
$\begin{array}{l}\text { Continua usando } \\
\text { mamadeira }\end{array}$ & $\%$ & $\mathrm{n}$ & $\%$ & $\mathrm{n}$ & $\%$ & $\mathrm{n}$ \\
\hline Sim & 59,5 & 22 & 40,5 & 15 & 100,0 & 37 \\
Não & 47,6 & 10 & 52,4 & 11 & 100,0 & 21 \\
\hline Total & 55,2 & 32 & 44,8 & 26 & 100,0 & 58 \\
\hline
\end{tabular}

Obs.: Ocorreram 3 não -respostas 
Estes resultados confirmam aqueles encontrados por Serra-Negra et al. (1997) que constataram que $57,4 \%$ das crianças com hábito de sucção deletérios, foram alimentadas por meio de mamadeira por um período maior que um ano. Coletti \& Bartholomeu (1998) também mencionaram o uso da mamadeira como fator predisponente para hábitos de sucção.

Vadiakas et al. (1998), encontraram que das crianças que utilizavam a mamadeira, independentemente do tempo de uso, mais de $50 \%$, apresentaram hábito de sucção de chupeta. O autor comentou que isto ocorre porque o bico da mamadeira e o da chupeta geralmente são feitos do mesmo material, e portanto, as crianças sugam a chupeta para substituir o bico da mamadeira.

Segundo Black et al. (1990), os bebês que são alimentados com mamadeira geralmente apresentam hábitos de sucção indesejáveis, especialmente se a mamadeira foi usada como um dispositivo para acalmar ou induzir o sono na criança. Nestes casos, após o desmame, os bebês tendem a apresentar hábito de sucção digital ou de chupeta para adormecer e se acalmar .

Encontrou-se que em mais da metade $(64,7 \%)$ das crianças a introdução da chupeta foi realizada pela mãe e por ambos os pais $(11,8 \%)$ (Figura 9). 


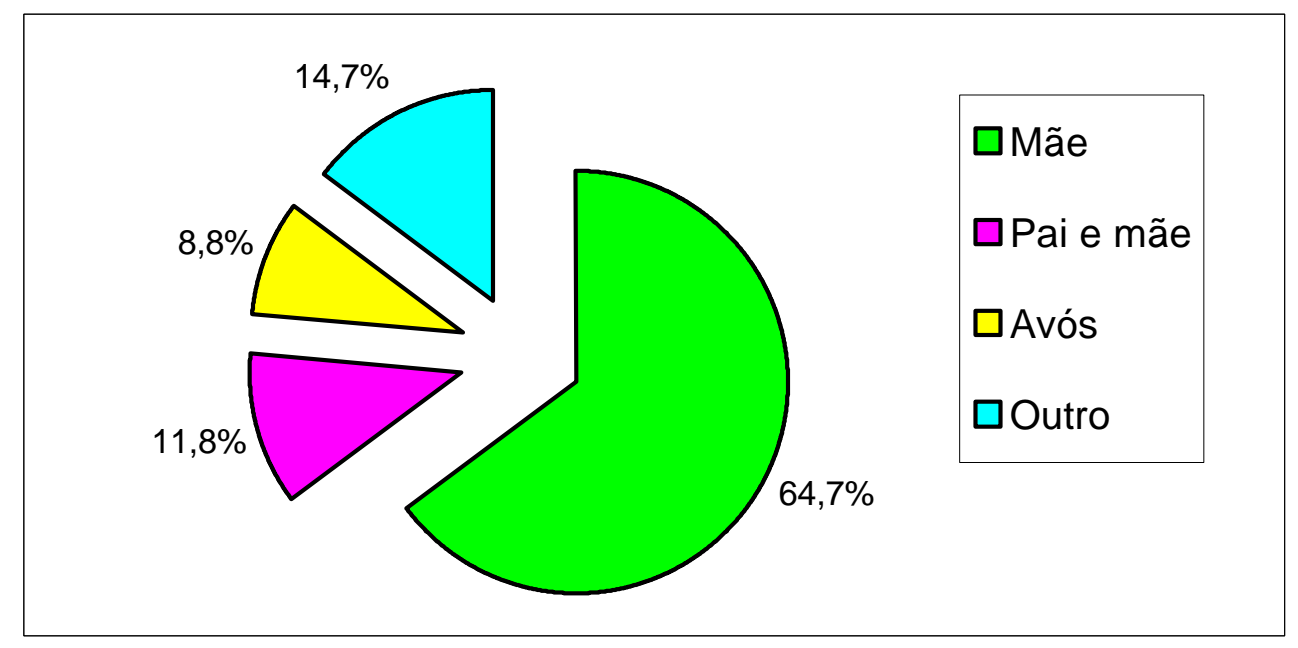

Figura 9 - Distribuição da freqüência relativa da variável "Quem introduziu a chupeta àcriança"

O início do uso da chupeta foi precoce na maioria das crianças. Em 79,4\% delas, ocorreu já no primeiro mês de vida, e em 5,9 \% no segundo (Figura 10). Estes resultados são similares ฆ̀⿴囗ueles encontrados por Coletti \& Bartholomeu (1998) que verificaram que $88,4 \%$ das crianças iniciaram o hábito de sucção de chupeta logo após o nascimento, e também ঐ̀lueles verificados no estudo de Tomas i et al. (1994), no qual a introdução da chupeta ocorreu em $62 \%$ dos casos já no primeiro dia de vida e em $21 \%$, do segundo dia até o trigésimo dia de vida.

Modéer et al. (1982) e Tomasi et al. (1994) observaram que uma porcentagem elevada de mães relatou ter oferecido a chupeta para a criança já na maternidade, $54 \%$ e $80 \%$, respectivamente. 
No estudo conduzido por Tomasi et al. (1994), as mães relataram terem usado mel, açúcar e até chá para ajudar na introdução e aceitação da chupeta pela criança.

Isto mostra a atitude materna de realmente querer introduzir a chupeta; uma vez que ela busca meios para facilitar a aceitação da chupeta pela criança.

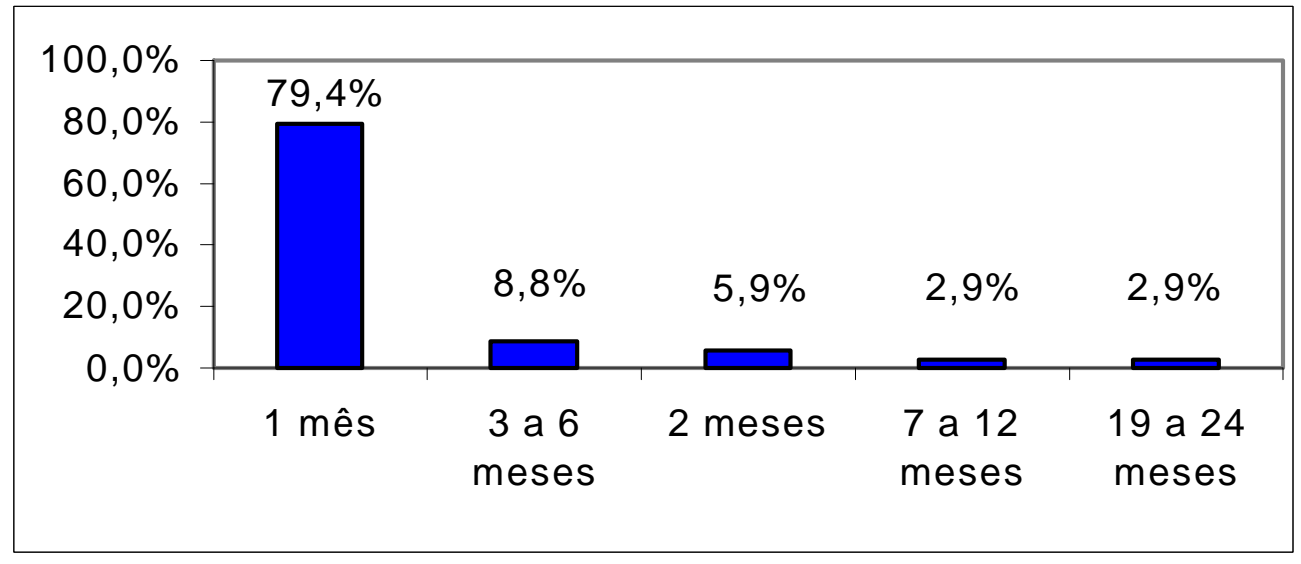

Figura 10 - Distribuição da freqüência relativa da variável "Idade de início da chupeta"

Como praticamente todas as crianças usavam chupeta desde os primeiros meses, o tempo de uso da chupeta entre as crianças que utilizavam a chupeta convencional ou anatômica foi similar, 44,6 e 43,3 meses, respectivamente (Tabela 5.17). 
TABELA 5.17 - Estatística descritiva da variável "Há quanto tempo usa chupeta" segundo a variável "Uso e tipo de chupeta"

\begin{tabular}{lcccccc}
\hline Uso e tipo de chupeta & $\mathrm{n}$ & Média & $\begin{array}{r}\text { Desvio } \\
\text { Padrão }\end{array}$ & Mínimo & Máximo & Mediana \\
\hline Usa anatômica & 20 & 43,3 & 7,43 & 32,0 & 60,0 & 42,0 \\
Usa convencional & 14 & 44,6 & 6,02 & 37,0 & 55,0 & 42,5 \\
\hline
\end{tabular}

A maioria das mães $(70,6 \%)$ relatou que a chupeta foi introduzida com o objetivo de tranqüilizar a criança ou acalmá-la e por ser normal a criança usar a chupeta $(11,8 \%)$ (Figura 11). A mesma tendência foi verificada por Coletti \& Bartholomeu (1998) quando observaram que a maioria das mães ofereceu a chupeta àcriança porque a família tinha este costume e para acalma-la quando esta chorava.

Nos relatos das mães colhidos por Serra-Negra et al. (1999), também foi constatada a associação da chupeta a uma função tranqüilizadora (93,6\%), assim como no estudo de Mathur et al. (1990), no qual $88,7 \%$ dos pais ou membro da família introduziram a chupeta para acalmar a criança. Modesto et al. (1999) encontraram que 83,7\% das mães entrevistadas acreditavam que a chupeta servia para acalmar a criança, e 4,1\% para distraí-la. Estes autores também verificaram que as mães ofereciam a chupeta àcriança, na maioria das vezes (42,9\%), sem qualquer motivo ou quando a criança chorava $(28,6 \%)$. 
Black et al. (1990) mencionaram que muitas vezes, se o bebê chorar, apesar de estar bem alimentado, a reação natural da mãe é a colocação da chupeta com o objetivo de mantê-lo tranqüilo, implicando, então, numa criança treinada inadvertidamente para buscar gratificação oral.

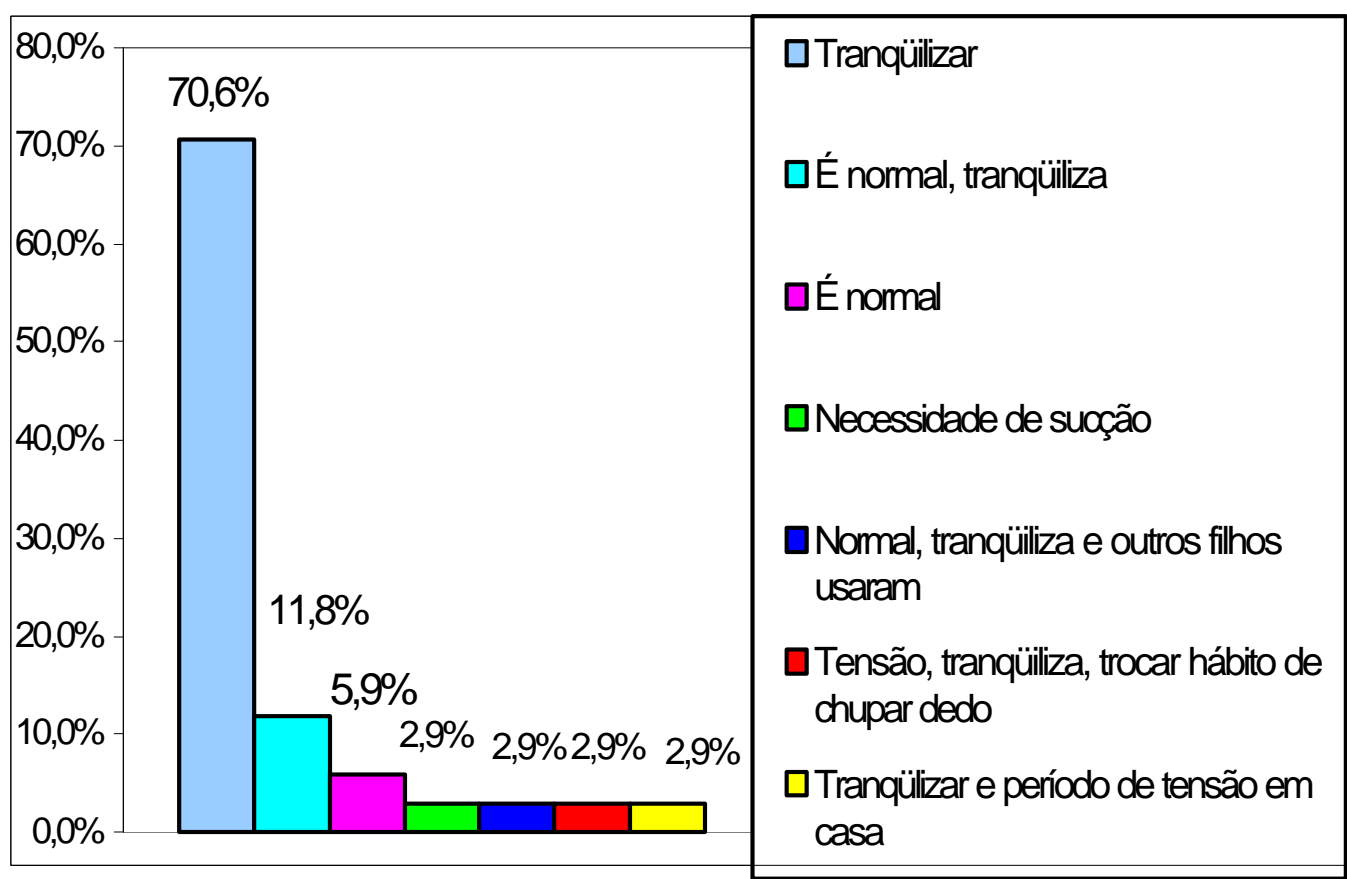

Figura 11 - Distribuição da freqüência relativa da variável " Por que iniciou o uso de chupeta"

Devido a idade das crianças (3 a 5 anos), a maioria das instituições de ensino participantes deste estudo não permitia que elas usassem as chupetas dentro do estabelecimento. Portanto, como era de se esperar, quase a totalidade das crianças participantes destes estudo $(85,3 \%)$ utilizava a chupeta somente em casa (Anexo A). 
As mães mencionaram que os fatores mais comumente associados ao uso da chupeta foram a hora de dormir $(48,5 \%)$ ou tensão e hora de dormir $(21,2 \%)$ (Figura 12). Isto obviamente estava relacionado com o momento do dia em que a criança sugava a chupeta. Um pouco mais da metade $(51,5 \%)$ das crianças sugava a chupeta só para dormir, $18,2 \%$ antes de dormir e $21,2 \%$ o dia inteiro (Figura 13).

Encontrou-se uma distribuição uniforme entre os dois grupos de chupetas estudados segundo o momento do dia em que era utilizada, sendo a maior prevalência relacionada ao ato de dormir (Figura 14). Estes resultados foram similares घ̀ueles encontrados por Coletti \& Bartholomeu (1998) e Modesto et al. (1999) em que a maioria das crianças procurava ou usava a chupeta para dormir.

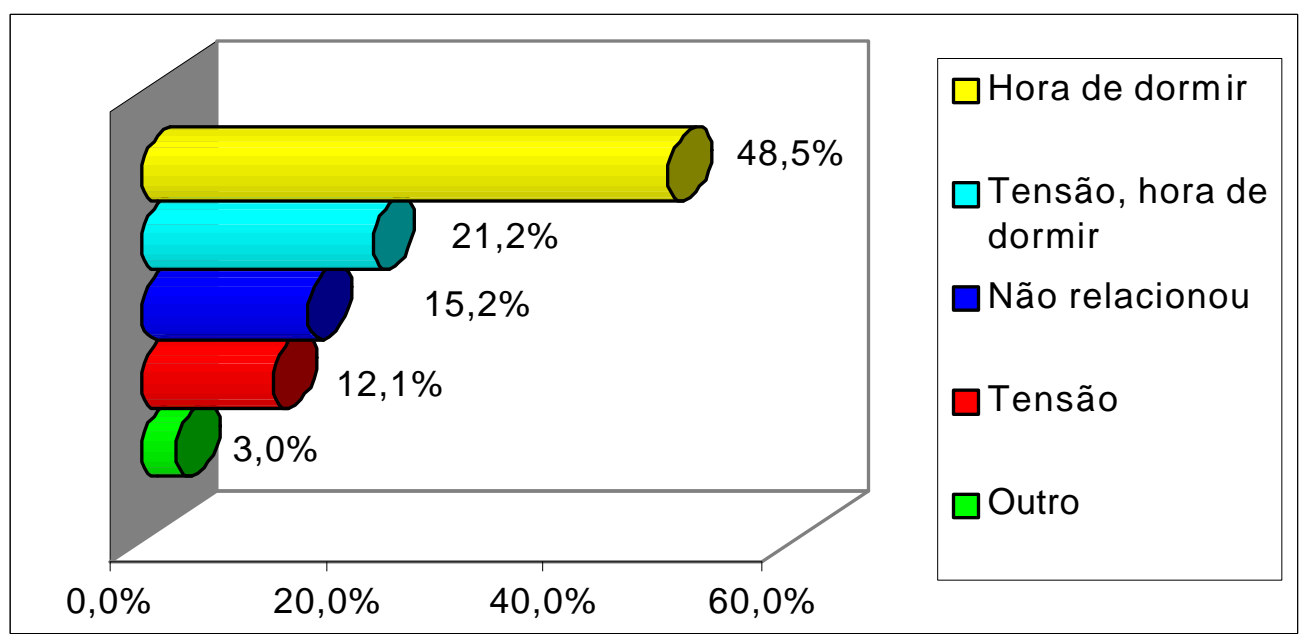

Figura 12 - Distribuição da freqüência relativa da variável "Relaciona uso de chupeta com que fatores?" 


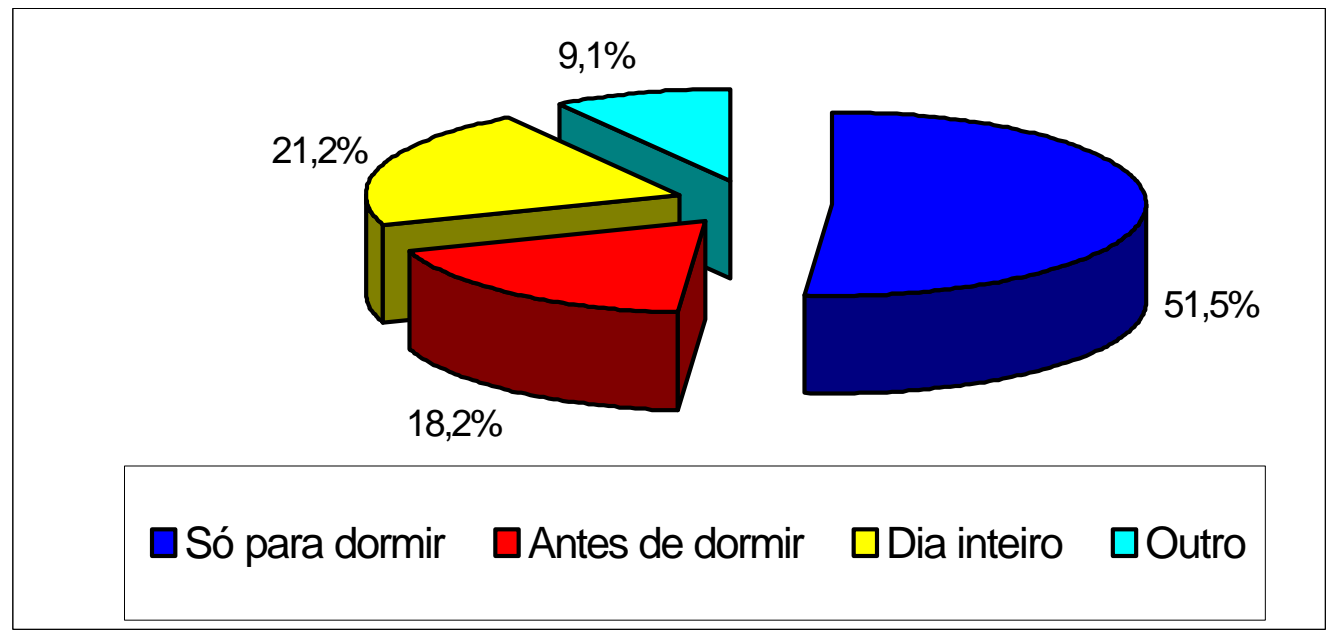

Figura 13 - Distribuição da freqüência relativa da variável "Momento do dia que criança usa chupeta"

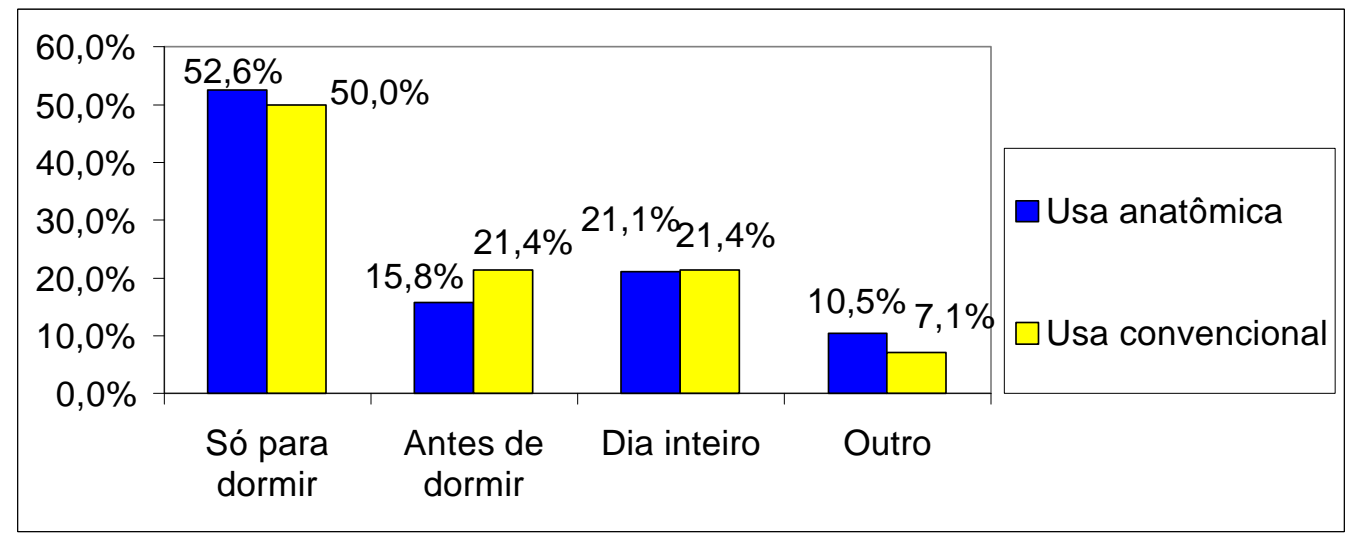

Figura 14 - Distribuição da freqüência relativa da variável "Momento do dia que usa chupeta com o tipo de chupeta"

Estes estudos mostram como é clara a associação do uso da chupeta e seu "efeito calmante" segundo as mães. Este fato também é bem representado pelos termos da língua Inglesa utilizados para a chupeta: 
pacifier, dummy e soother. Segundo Webter's Ninth Collegiate Dictionary (1983), dummy é um termo utilizado para descrever alguém que é incapaz de falar ou é geralmente quieto e não fala. O termo pacifier, já denota a natureza calmante ou pacificadora deste artifício; assim como soother, que é algo que alivia, traz conforto, quietude, sossego, paz e acalma.

Diversos autores mencionaram que o hábito de sucção é utilizado pela criança como válvula de escape para tensão emocional nos momentos em que sua segurança é ameaçada ou para satisfazer suas necessidades psico-emocionais (Sim \& Finn, 1973; Adimari, 1975; Baer \& Lester, 1987; Black et al., 1990). Outros relataram que o hábito de sucção proporciona prazer e satisfação (Baer \& Lester, 1987; Coeli \& Toledo, 1994; Norman, 1997) e consolo (Baer \& Lester).

Segundo Norman (1997), a primeira associação de prazer do bebê está relacionada ao ato de sugar e alimentar-se. Portanto, o hábito de sucção promove conforto, relaxamento e prazer. Quando o ato de sucção torna-se involuntário, a criança passa a ter esta atividade para relaxar, quando está chateada, apreensiva, para dormir ou quando emocional ou fisicamente estressada.

Paunio et al. (1993) encontraram um dado interessante: a associação entre o uso da chupeta e o fato da criança dormir no quarto dos pais. Provavelmente, devido àtentativa de acalmar ou tranqüilizar a criança, os pais ofereciam com freqüência a chupeta.

A distribuição do modo de sugar a chupeta foi semelhante nos grupos das duas chupetas (Figura 15). Segundo relato das mães, pode-se 
observar que $42,1 \%$ e $35,7 \%$ das crianças que usavam, respectivamente, chupetas anatômicas ou convencionais, sugavam sempre a chupeta.

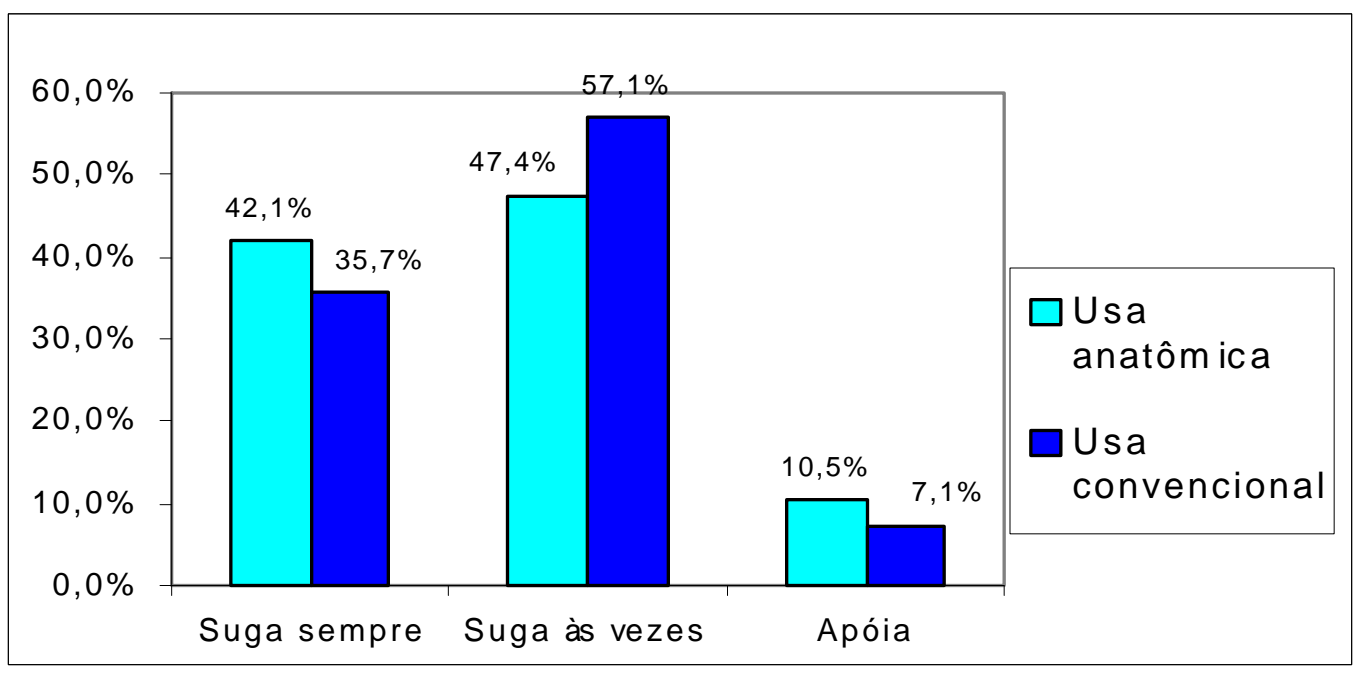

Figura 15 - Distribuição da freqüência relativa da variável "Como suga" segundo o tipo de chupeta

Segundo as normas de segurança da ABNT descritas no verso das embalagens das chupetas nacionais e orientações nas embalagens das importadas, estas não devem ficar presas àroupa da criança para evitar estrangulamento. Mesmo com este alerta, constatou-se que $32,4 \%$ das mães relataram que prendiam a chupeta àroupa da criança (Figura 16). Esta freqüência foi bem maior (85,7\%) no estudo de Modesto et al. (1999).

Outra atitude freqüentemente realizada pelas mães foi a de permitir que as crianças permanecessem com mais de uma chupeta ao mesmo tempo. Isto favorece o hábito de sucção da chupeta, em vez de 
desestimulá-lo. Das crianças avaliadas, verificou-se que 19,4\% tinham o hábito de ficar com mais de uma chupeta ao mesmo tempo (Figura 17).

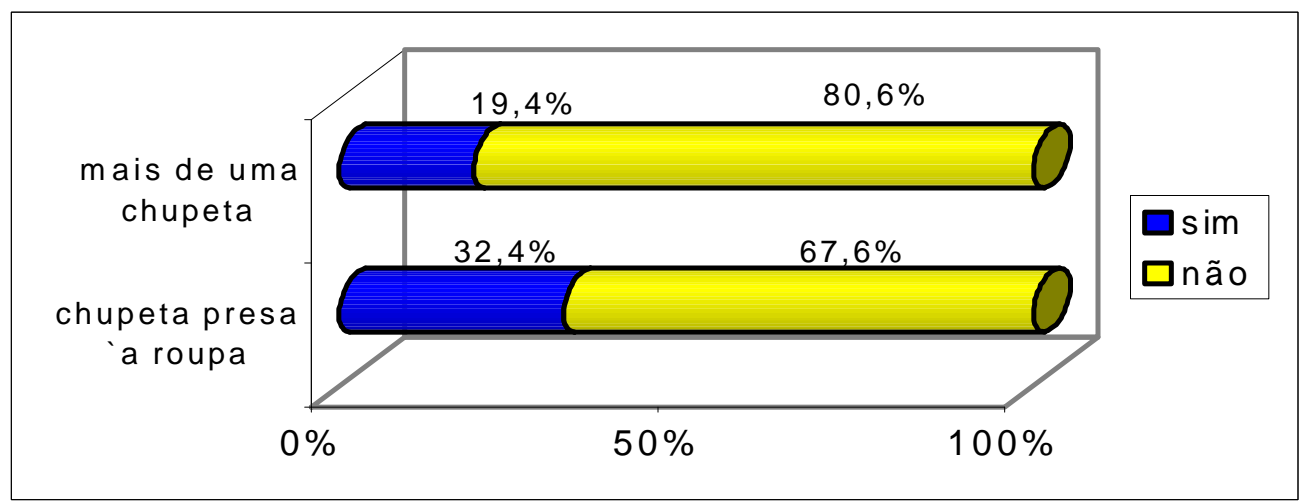

Figura 16 - Distribuição da freqüência relativa das variáveis "Fica com mais de uma chupeta" e "chupeta fica presa àroupa"

Atualmente existem cursos para gestantes onde elas são orientadas sobre os primeiros cuidados com o bebê e o parto em si. A população carente que não tem acesso a estes cursos, contam, muitas vezes, com o pré-natal para suprir estas informações. A Tabela 5.4 mostra que não houve dependência $(p=0,907)$ entre a orientação recebida quanto ao uso de chupeta em cursos ou pré-natal, com o hábito da criança sugar ou não a chupeta.

Espindola et al. (2000) encontraram que as mães de crianças recém-nascidas que fizeram o pré-natal no HUPE foram as que menos compraram chupeta $(p<0,05)$ e mamadeira $(p=0,09)$. Mostrando que orientações fornecidas \$̀ gestantes são muito importantes e podem mudar 
atitudes e comportamento destas, favorecendo a saúde, crescimento e o desenvolvimento do bebê.

Certas atitudes maternas mesmo antes da criança nascer mostram que, assim como a mamadeira, o uso da chupeta é comum e disseminado em nossa cultura.

A chupeta é considerada como parte do enxoval do bebê como relatam Tomasi et al. (1994) e Modesto et al. (1999) e algumas mães até levam-na para maternidade. No estudo de Espindola et al. (2000), 60,0\% das mães de recém-nascidos relataram terem comprado mamadeira e $43,2 \%$ a chupeta.

Foi verificado que as mães de $70,2 \%$ das crianças avaliadas, relataram que havia uma ou mais chupetas no enxoval do bebê (Figura 17).

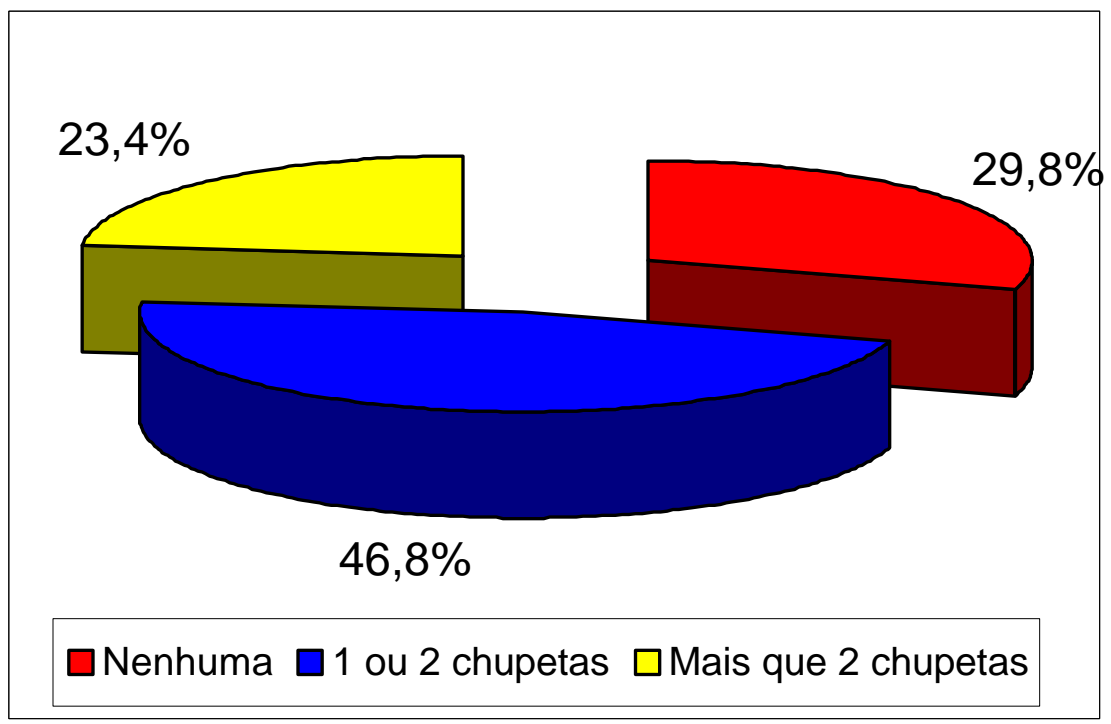

Figura 17 - Distribuição da freqüência relativa da variável "Número de chupetas do enxoval do bebê" 
A presença de chupetas no enxoval, mostrou influência significante no hábito de usar ou não a chupeta $(p=0,033)$, mostrado na Tabela 5.4.

Ao analisar a Tabela 5.18 observa-se que $81,8 \%$ das crianças que tinham uma ou mais chupetas no seu enxoval quando bebê, apresentavam o hábito de sucção de chupeta. Praticamente a metade $(42,9 \%)$ das crianças que não tinha a chupeta em seu enxoval, apresentavam este hábito de sucção.

Fato semelhante foi observado por Serra-Negra et al. (1999) ao constatar que todas as mães entrevistadas que relataram que tinham oferecido chupeta aos seus filhos, afirmaram que este artefato fazia parte do enxoval do bebê.

TABELA 5.18 - Distribuição das freqüências da variável "Usa chupeta" segundo a variável "Quantas chupetas no enxoval"

\begin{tabular}{|c|c|c|c|c|c|c|}
\hline \multirow{2}{*}{$\begin{array}{l}\text { Uso de } \\
\text { enxoval }\end{array}$} & \multicolumn{2}{|c|}{ Sim } & \multicolumn{2}{|c|}{ Não } & \multicolumn{2}{|c|}{ Total } \\
\hline & $\%$ & $\mathrm{n}$ & $\%$ & $\mathrm{n}$ & $\%$ & $\mathrm{n}$ \\
\hline Nenhuma & 42,9 & 6 & 57,1 & 8 & 100,0 & 14 \\
\hline 1 ou 2 chupetas & 81,8 & 18 & 18,2 & 4 & 100,0 & 22 \\
\hline Mais que 2 chupetas & 81,8 & 9 & 18,2 & 2 & 100,0 & 11 \\
\hline Total & 70,2 & 33 & 29,8 & 14 & 100,0 & 47 \\
\hline
\end{tabular}

Obs.: Ocorreram 14 não-respostas 
Concordamos com Tomasi et al. (1994) ao afirmar que na sociedade atual, a chupeta é aceita como natural e vista como parte integrante, e até muitas vezes, indispensável do enxoval do bebê. Culturalmente observa-se o quão enraizado é este fato, quando a gestante anuncia que está grávida e os primeiros presentes geralmente oferecidos pelos amigos e parentes, são a mamadeira e a chupeta.

O fato das mães terem levado as chupetas para a maternidade também não foi um fator significante $(p=0,261)$ (Tabela 5.4) para a instalação do hábito de sugar chupeta na criança.

Um número reduzido de mães (14,0\%) (Tabela 5.19) relatou ter levado a chupeta àmaternidade e ter usado -a (5,5\%) (Tabela 5.20).

TABELA 5.19 - Distribuição das freqüências da variável "Levou chupetas para a maternidade"

\begin{tabular}{l|c|c}
\hline $\begin{array}{c}\text { Levou chupetas para } \\
\text { maternidade }\end{array}$ & $\mathrm{n}$ & $\%$ \\
\hline Sim & 8 & $14,0 \%$ \\
Não & 49 & $86,0 \%$ \\
\hline Total & 57 & $100,0 \%$ \\
\hline Obs: Ocorreram 4 não-respostas
\end{tabular}

Obs.: Ocorreram 4 não-respostas 
TABELA 5.20 - Distribuição das freqüências da variável "Usou chupeta na maternidade"

\begin{tabular}{l|c|c}
\hline $\begin{array}{c}\text { Usou chupeta na } \\
\text { maternidade }\end{array}$ & $\mathrm{n}$ & $\%$ \\
\hline Sim & 3 & $5,5 \%$ \\
Não & 52 & $94,5 \%$ \\
\hline Total & 55 & $100,0 \%$ \\
\hline
\end{tabular}

Obs.: Ocorreram 6 não-respostas

Os estudos de Modéer et al. (1982) e Tomasi et al. (1994) apresentam uma porcentagem expressiva de mães, 54\% e 80\%, respectivamente, que relataram terem oferecido a chupeta para o bebê já na maternidade, reafirmando que a introdução da chupeta é precoce.

Curiosamente, 98,3\% das mães do presente estudo afirmaram que acreditavam que o uso da chupeta poderia provocar danos àoclusão.

TABELA 5.21 - Distribuição das freqüências da variável "Uso inadequado de chupeta pode causar dano"

\begin{tabular}{l|c|c}
\hline $\begin{array}{c}\text { Mãe acha que uso } \\
\text { inadequado de } \\
\text { chupeta pode causar } \\
\text { dano }\end{array}$ & $\mathrm{n}$ & $\%$ \\
\hline $\mathrm{Sim}$ & 57 & $98,3 \%$ \\
Não & 1 & $1,7 \%$ \\
\hline Total & 58 & $100,0 \%$ \\
\hline
\end{tabular}

Obs.: Ocorreram 3 não-respostas 


\subsection{Avaliação dos arcos dentais}

Todas as características dos arcos dentais foram correlacionadas com o uso e tipo de chupeta.

TABELA 5.22 - Testes de Independência (Qui-quadrado de Pearson) entre as variáveis da avaliação anatômica e a variável "Uso e tipo de chupeta"

\begin{tabular}{lcc}
\hline \multicolumn{1}{c}{$\begin{array}{c}\text { Variável da avaliação } \\
\text { dos arcos dentais }\end{array}$} & $\begin{array}{c}\text { Valor da estatística } \\
\text { Qui-quadrado de } \\
\text { Pearson }\end{array}$ & $\begin{array}{c}\text { Nível descritivo } \\
\text { exato }\end{array}$ \\
\hline Tipo de arco superior & 2,955 & 0,227 \\
\hline Tipo de arco inferior & 5,325 & 0,081 \\
\hline Desvio de linha média & 7,079 & 0,133 \\
\hline Relação canina lado direito & $\mathbf{1 9 , 2 8 1}$ & $\mathbf{0 , 0 0 0 ^ { * }}$ \\
\hline Relação canina lado esquerdo & $\mathbf{1 0 , 9 6 8}$ & $\mathbf{0 , 0 1 3 ^ { * }}$ \\
\hline Espaço primata superior & 1,082 & 0,790 \\
\hline Espaço primata inferior & 2,599 & 0,342 \\
\hline Relação molar lado direito & 3,857 & 0,439 \\
\hline Relação molar lado esquerdo & 2,449 & 0,691 \\
\hline Mordida cruzada posterior & $\mathbf{1 4 , 6 4 3}$ & $\mathbf{0 , 0 1 0 ^ { * }}$ \\
\hline Sobressaliência normal \# & $\mathbf{1 4 , 1 8 1}$ & $\mathbf{0 , 0 0 1}{ }^{*}$ \\
\hline Sobremordida & $\mathbf{2 2 , 8 5 4}$ & $\mathbf{0 , 0 0 1}$ \\
\hline \# Considerado normal a sobressaliência entre $0-2$ milímetros, segundo Foster \& Hamilton, 1969. \\
* Estatisticamente significante
\end{tabular}

A Tabela 5.22 mostra que o tipo de arco superior e inferior, espaço primata superior e inferior, linha média e relação molar em ambos os lados, não tiveram relação estatisticamente significante quanto ao uso e tipo da chupeta. 
Portanto, estes dados serão descritos conjuntamente para as 61 crianças avaliadas.

Das 61 examinadas, 77,0 \% apresentavam arco do tipo I de Baume na maxila e 70,5\% na mandíbula. Não foi observado desvio de linha média em $73,8 \%$ das crianças. O espaço primata superior estava presente em $95,1 \%$ das crianças e o inferior em $85,2 \%$. A freqüência dos tipos de relação molar do lado direito e esquerdo foram iguais entre si sendo $11,5 \%$ para relação de degrau distal para mandíbula, 50,8\% para relação de degrau mesial para mandíbula e 37,7\% para relação em plano reto (Anexo B).

Estes resultados estão de acordo com a literatura que afirma que o arco tipo I de Baume é mais freqüente que o tipo II (Baume, 1950) e que o espaço primata é mais comum no arco superior do que no inferior (Baume, 1950; Foster \& Hamilton, 1969; Albejante, 1975).

Diferentemente dos resultados obtidos, outros autores encontraram que a relação terminal dos segundo molares decíduos em plano reto foi mais prevalente que o degrau mesial, e a relação distal a menos freqüente (Baume, 1950; Albejante, 1975; Farsi \& Salama, 1996; Soviero et al., 1997). Porém, a prevalência foi diferente entre eles.

Por outro lado, encontrou-se relação altamente significante entre o uso e tipo de chupeta e a relação canina do lado direito $(p=0,000)$ e esquerdo $(p=0,013)$, mordida cruzada posterior $(p=0,010)$ e sobremordida $(p=0,001)$ (Tabela 5.22).

Inúmeros autores relacionaram hábitos bucais nocivos com maloclusão (Larsson, 1972; Larsson, 1975; Larsson, 1986; Monguilhott, 1986; 
Peters et al., 1986; Hännuksela \& Väännäen, 1987; Silva Filho et al., 1991; Adair et al., 1992; Paunio et al., 1993; Adair et al., 1995; Chan et al., 1996; Serra-Negra et al., 1997; Farsi et al., 1997; Robles et al., 1999).

A relação canina do lado direito mais freqüente no grupo que não usou chupeta foi a Classe I $(81,5 \%)$, enquanto nas crianças que usavam chupeta a relação canina Classe II deste mesmo lado, foi mais prevalente respectivamente, $60,0 \%$ e $71,4 \%$, para as crianças dos grupos das chupetas anatômica e convencional (Figura 19).

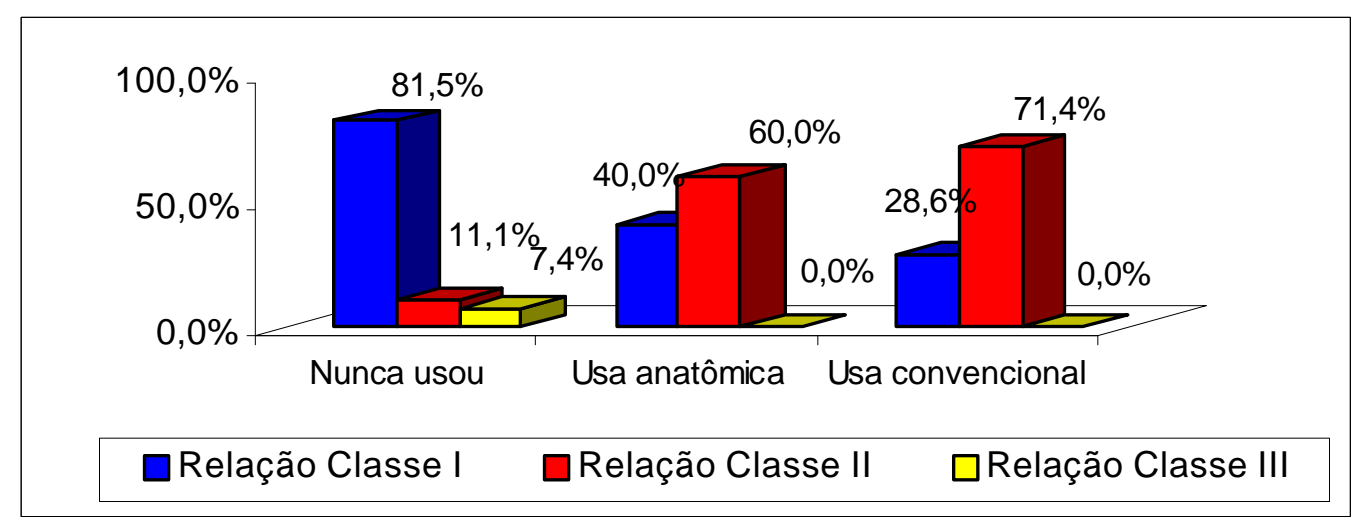

Figura 18 - Distribuição percentual da variável "Relação canina lado direito" segundo o "Uso e tipo de chupeta"

A Tabela 5.23 mostra que não houve diferença significante entre as probabilidades de ocorrência de relação canina Classe I no lado direito entre as crianças que usavam chupetas anatômicas e as que usavam as convencionais. Por outro lado, esta probabilidade foi significativamente maior nas crianças que nunca usaram chupeta quando comparado s̀ que usavam. 
TABELA 5.23 - Intervalos de confiança para as diferenças entre as probabilidades de relação Classe I na variável "Relação canina - lado direito", com coeficiente de confiança global de $95 \%$

\begin{tabular}{cccccc}
\hline & $\begin{array}{c}\text { Estimativa da } \\
\text { Diferença }\end{array}$ & Estatística z & $\begin{array}{c}\text { Erro padrão } \\
\text { da }\end{array}$ & $\begin{array}{c}\text { Limite } \\
\text { inferior do } \\
\text { intervalo }\end{array}$ & $\begin{array}{c}\text { Limite } \\
\text { superior do } \\
\text { intervalo }\end{array}$ \\
\hline $\mathrm{P}(\mathrm{RI} \mid \mathrm{NU})-\mathrm{P}(\mathrm{RI} \mid \mathrm{UO})$ & 0,415 & 2,394 & 0,133 & 0,097 & 0,732 * \\
\hline $\mathrm{P}(\mathrm{RI} \mid \mathrm{NU})-\mathrm{P}(\mathrm{RI} \mid \mathrm{UC})$ & 0,529 & 2,394 & 0,142 & 0,189 & 0,869 * \\
\hline $\mathrm{P}(\mathrm{RI} \mid \mathrm{UO})-\mathrm{P}(\mathrm{RI} \mid \mathrm{UC})$ & 0,114 & 2,394 & 0,163 & $-0,276$ & 0,505 \\
\hline
\end{tabular}

* Estatisticamente significante

Obs.: $P(R I \mid N U)$ = probabilidade de Relação Classe I, dado que a criança nunca usou chupeta. $\mathrm{P}(\mathrm{RI} \mid \mathrm{UO})=$ probabilidade de Relação Classe I, dado que a criança usa chupeta anatômica; $\mathrm{P}(\mathrm{RI} \mid \mathrm{UC})=$ probabilidade de Relação Classe I, dado que a criança usa chupeta convencional.

A relação canina Classe I foi mais prevalente no lado esquerdo no grupo que não sugava chupeta $(85,2 \%)$ e naquele de chupeta anatômica (60,0\%). Já no grupo da chupeta convencional, a relação canina Classe II foi a mais freqüente $(57,1 \%)$ (Figura 19$)$.

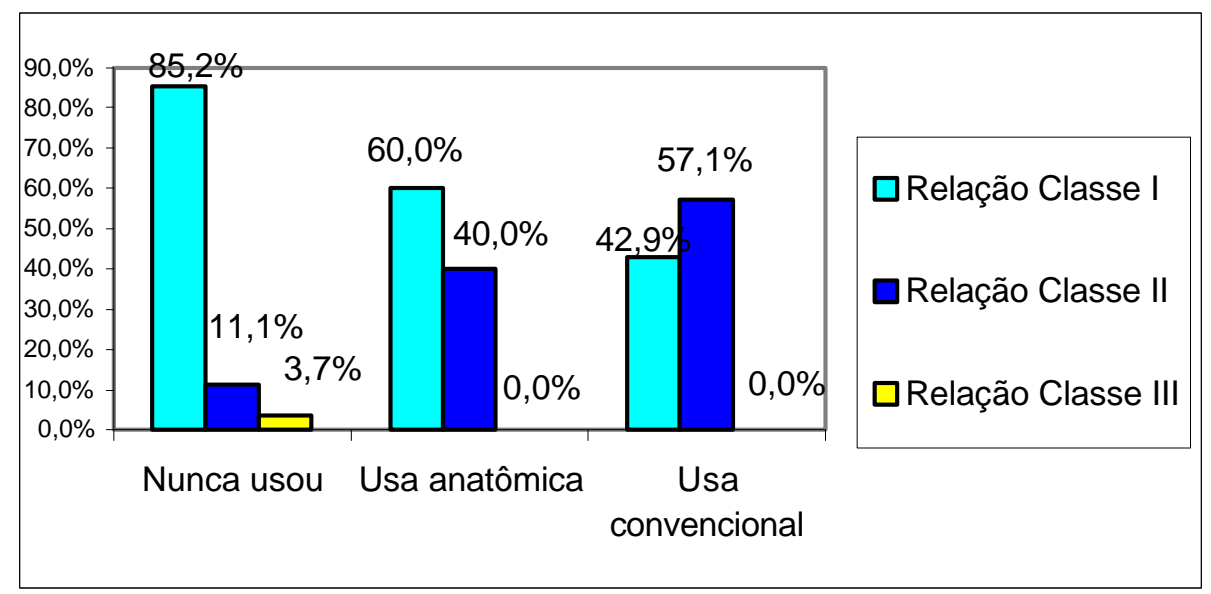


Figura 19 - Distribuição percentual da variável "Relação canina lado esquerdo" segundo "Uso e tipo de chupeta"

Quanto àrelação canina do lado esquerdo, encontrou -se que a única diferença significante identificada foi a probabilidade de relação canina Classe I entre as crianças que nunca usaram chupeta e as que usavam chupeta convencional, sendo que aquelas que nunca usaram apresentaram uma probabilidade maior de relação canina Classe I (Tabela 5.24). Esta diferença entre os lados poderia ocorrer devido ao fato de algumas crianças sugarem a chupeta deslocada para um dos lados, comumente observado na clínica; entretanto, como esta pergunta não foi incluída no questionário, não foi possível comprovar este achado.

TABELA 5.24 - Intervalos de confiança para as diferenças entre as probabilidades de relação Classe I na variável "Relação canina - lado esquerdo", com coeficiente de confiança global de $95 \%$

\begin{tabular}{|c|c|c|c|c|c|}
\hline Diferença & $\begin{array}{c}\text { Estimativa } \\
\text { da } \\
\text { diferença }\end{array}$ & Estatística & $\begin{array}{c}\text { Erro } \\
\text { padrão da i } \\
\text { zestimativa }\end{array}$ & $\begin{array}{c}\text { Limite } \\
\text { inferior do } \\
\text { intervalo } \\
\end{array}$ & $\begin{array}{c}\text { Limite superior } \\
\text { do intervalo }\end{array}$ \\
\hline$P(R I \mid N U)-P(R I \mid U O)$ & 0,252 & 2,394 & 0,129 & $-0,057$ & 0,561 \\
\hline$P(R I \mid N U)-P(R I \mid U C)$ & 0,423 & 2,394 & 0,149 & 0,067 & 0,780 * \\
\hline $\mathrm{P}(\mathrm{RI} \mid \mathrm{UO})-\mathrm{P}(\mathrm{RI} \mid \mathrm{UC})$ & 0,171 & 2,394 & 0,172 & $-0,240$ & 0,583 \\
\hline
\end{tabular}


Adair et al. (1992) não encontraram diferença quanto a prevalência da relação canina Classe I entre o grupo de crianças que não sugava chupeta, e aquelas crianças que sugavam chupeta convencional ou anatômica.

Em estudo posterior, Adair et al. (1995) encontraram uma diferença grande entre prevalência de relação canina Classe II de um ou ambos os lados, quando do uso das chupetas anatômicas e convencionais $(26,8 \%$ e 5,3\%, respectivamente).

Os resultados obtidos neste estudo estão de acordo com outros, em que a relação canina Classe I foi mais prevalente no grupo das crianças sem hábitos de sugar chupeta do que no grupo com este hábito (Bowden, 1966a; Larsson, 1975; Ravn, 1976). Assim como a prevalência de relação canina Classe II foi maior nas crianças que sugavam chupeta (Bowden, 1966a; Ravn, 1976; Adair et al., 1995; Larsson, 1975; Farsi et al., 1997).

Ravn (1976) encontrou uma prevalência de 45,9\% para relação canina Classe II em ambos os lados.

Nos estudos conduzidos por Bowden (1966a), Ravn (1976) e Adair et al. (1995) também foi verificado que em algumas crianças não havia coincidência de relação canina nos lados direito e esquerdo.

A mordida cruzada posterior foi encontrada somente nas crianças que mantinham o hábito de sugar chupeta, tendo sido mais prevalente no grupo daquelas que usavam chupeta convencional (14,3\%) do que nas do grupo de chupeta anatômica (10,0\%) (Tabela 5.25 e Figura 20). 
TABELA 5.25 - Distribuição das freqüências da variável "Mordida cruzada posterior" segundo a variável "Uso e tipo de chupeta"

\begin{tabular}{|c|c|c|c|c|c|c|c|c|c|c|c|c|}
\hline \multirow{2}{*}{$\begin{array}{l}\text { Uso e tipo } \\
\text { de chupeta }\end{array}$} & \multicolumn{2}{|c|}{$\begin{array}{c}\text { Não } \\
\text { apresentava }\end{array}$} & \multicolumn{2}{|c|}{$\begin{array}{l}\text { Unilateral } \\
\text { lado } \\
\text { direito }\end{array}$} & \multicolumn{2}{|c|}{$\begin{array}{c}\text { Unilateral } \\
\text { lado } \\
\text { esquerdo }\end{array}$} & \multicolumn{2}{|c|}{ Bilateral } & \multicolumn{2}{|c|}{$\begin{array}{c}\text { Topo a } \\
\text { topo } \\
\text { bilateral }\end{array}$} & \multicolumn{2}{|c|}{ Total } \\
\hline & $\%$ & $n$ & $\%$ & $n$ & $\%$ & $\mathrm{n}$ & $\%$ & $n$ & $\%$ & $n$ & $\%$ & $n$ \\
\hline Nunca usou & 100,0 & 27 & 0,0 & 0 & 0,0 & 0 & 0,0 & 0 & 0,0 & 0 & 100,0 & 27 \\
\hline Usa anatômica & 90,0 & 18 & 5,0 & 1 & 0,0 & 0 & 5,0 & 1 & 0,0 & 0 & 100,0 & 20 \\
\hline Usa convencional & 78,6 & 11 & 0,0 & 0 & 14,3 & 10 & 0,0 & 0 & 7,1 & 1 & 100,0 & 14 \\
\hline Total & 91,8 & 56 & 1,6 & 1 & 3,3 & 2 & 1,6 & 1 & 1,6 & 1 & 100,0 & 61 \\
\hline
\end{tabular}

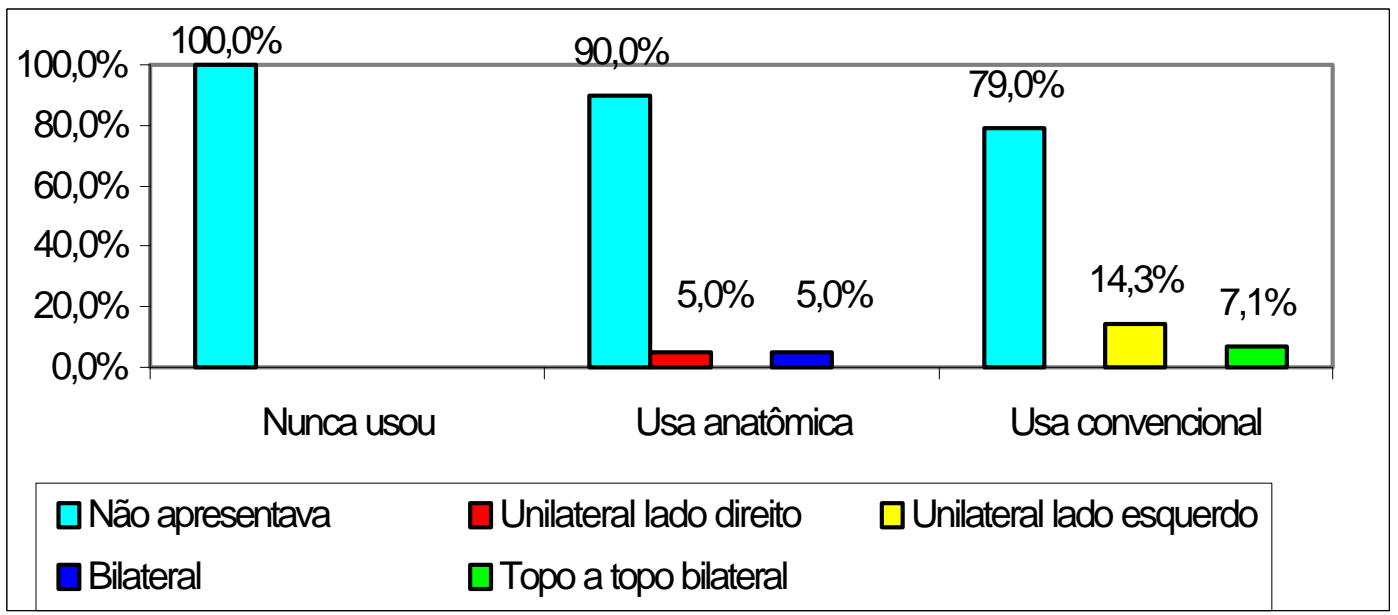

Figura 20 - Distribuição da freqüência da variável "Mordida cruzada posterior" segundo o uso e tipo de chupeta

Os Testes de Independência entre as variáveis "Mordida cruzada posterior" e o "Uso e tipo de chupeta" mostraram que há diferença houve diferença estatisticamente significante entre as crianças que nunca sugaram 
chupeta com somente छ̀uelas que sugaram chupeta convencional $(p=0,034)$ (Tabela 5.26).

TABELA 5.26 - Testes de Independência (Qui-quadrado de Pearson) entre "Mordida cruzada posterior" e "Uso e tipo de chupeta", tomando as categorias de "Uso e tipo de chupeta" duas a duas

\begin{tabular}{cccc}
\hline & \multicolumn{4}{c}{$\begin{array}{c}\text { Valor da estatística } \\
\text { Qui-quadrado de } \\
\text { Ceategorias }\end{array}$} & $\begin{array}{c}\text { Nível descritivo } \\
\text { exato }(\mathrm{p})\end{array}$ \\
\hline Nunca usou e Usa convencional & 6,242 & $0,034^{*}$ \\
Nunca usou & e $\quad$ Usa anatômica & 2,820 & 0,176 \\
Usa convencional e Usa anatômica & 5,812 & 0,150 \\
\hline
\end{tabular}

${ }^{*}$ Estatisticamente significante

Em relação àmordida cruza da posterior, não há uma concordância entre os resultados obtidos pelos diversos autores consultados. Alguns não encontraram diferença significante entre o grupo controle (sem hábito de sucção de chupeta) com aquele que sugava chupeta (Bowden, 1966b; Larsson, 1983; Adair et al., 1992; Farsi et al.,1997). Já as investigações conduzidas por Larsson, 1975; Modéer et al., 1982; Peters et al., 1986; Lindner \& Modeér, 1989; Paunio et al.,1993; Øgaard et al., 1994; Larsson, 1994; Adair et al., 1995; Serra-Negra et al., 1997, apresentaram associação entre o uso de chupeta e mordida cruzada posterior; enquanto outros (Larsson, 1986; Lindsten et al., 1996) apenas mencionaram a relação entre mordida cruzada posterior e hábito de sucção de chupeta. 
Em estudo preliminar, Adair et al. (1992) não encontraram diferença significante de mordida cruzada posterior, entre as crianças que sugavam chupeta anatômica ou aquelas que utilizam a convencional.

Posteriormente, em 1995, Adair et al. observaram uma prevalência de $15,9 \%$ e $13,2 \%$ para mordida cruzada posterior para as crianças que sugavam chupeta convencional ou anatômica, respectivamente; porém, não houve diferença significante entre estes dois grupos, confirmando os resultados obtidos no presente estudo.

A Análise de Variância mostrou haver diferença entre os três grupos para a sobressaliência $(p=0,000)($ Anexo $B)$.

Os intervalos de confiança de Bonferroni para a variável dimensão de sobressaliência mostraram que houve relação significante entre as crianças que nunca usaram chupeta e aquelas que usavam-na. Porém, não houve associação entre os tipos de chupeta e esta variável (Tabela 5.27).

TABELA 5.27 - Intervalos de confiança de Bonferroni para a variável "Sobressaliência (em milímetros)" com coeficiente de confiança global de 95\%

\begin{tabular}{|c|c|c|c|c|}
\hline Uso e tipo de chupeta (I) & $\begin{array}{c}\text { Uso e tipo de chupeta } \\
(\mathrm{J})\end{array}$ & $\begin{array}{c}\text { Diferença } \\
\text { entre as } \\
\text { médias (I-J) }\end{array}$ & $\begin{array}{l}\text { Limite } \\
\text { inferior }\end{array}$ & $\begin{array}{l}\text { Limite } \\
\text { superior }\end{array}$ \\
\hline Nunca usou & Usa anatômica & $-2,198$ & $-3,554$ & $-0,843^{*}$ \\
\hline Nunca usou & Usa convencional & $-2,332$ & $-3,816$ & $-0,847^{*}$ \\
\hline Usa anatômica & Usa convencional & $-0,133$ & $-1,688$ & 1,422 \\
\hline
\end{tabular}

* Estatisticamente significante 
Pela análise da Tabela 5.28, verifica-se que $88,0 \%$ das crianças do grupo controle apresentavam sobressaliência normal (0-2 milímetros), e que a prevalência desta característica foi bem menor para as crianças que sugavam chupeta convencional $(35,7 \%)$ ou anatômica $(42,1 \%)$.

TABELA 5.28 - Distribuição das freqüências da variável "Sobressaliência normal" segundo a variável "Uso e tipo de chupeta"

\begin{tabular}{l|cc|cc|c|c}
\hline & $\begin{array}{c}\text { Sobressaliência } \\
\text { normal }\end{array}$ & \multicolumn{2}{|c|}{ Sim } & \multicolumn{2}{c|}{ Não } & \multicolumn{2}{c}{ Total } \\
Uso e tipo & $\%$ & $\mathrm{n}$ & $\%$ & $\mathrm{n}$ & $\%$ & $\mathrm{n}$ \\
de chupeta & 88,0 & 22 & 12,0 & 3 & 100,0 & 25 \\
Nunca usou & 42,1 & 8 & 57,9 & 11 & 100,0 & 19 \\
Usa anatômica & 35,7 & 5 & 64,3 & 9 & 100,0 & 14 \\
Usa convencional & 60,3 & 35 & 39,7 & 23 & 100,0 & 58 \\
\hline Total & & &
\end{tabular}

De acordo com a Tabela 5.29, que apresenta os resultados em milímetros, verifica-se que a média da sobressaliência foi menor nas crianças que nunca teve hábito de sucção de chupeta do que naquelas usavam chupeta, a qual foi praticamente a mesma. Observando a mediana, verificou-se que esta foi menor no grupo controle do que no grupo da chupeta anatômica que por sua vez, é menor que no grupo da chupeta convencional, ou seja, no grupo que nunca usou chupeta, $50 \%$ das crianças tinham sobressaliência de até $1 \mathrm{~mm}$, enquanto no grupo da chupeta convencional, 50\% tinham sobressaliência de até $4 \mathrm{~mm}$ 
TABELA 5.29 - Estatística descritiva da variável "Sobressaliência (em milímetros)" segundo a variável "Uso e tipo de chupeta"

\begin{tabular}{lcccccc}
\hline $\begin{array}{c}\text { Uso e tipo de } \\
\text { chupeta }\end{array}$ & $\mathrm{n}$ & Média & $\begin{array}{c}\text { Desvio } \\
\text { Padrão }\end{array}$ & Mínimo & Máximo & Mediana \\
\hline Nunca usou & 25 & 1,3 & 1,07 & 0,0 & 4,0 & 1,0 \\
\hline Usa anatômica & 19 & 3,6 & 2,33 & 0,5 & 10,0 & 3,0 \\
\hline $\begin{array}{l}\text { Usa convencional } \\
\text { Obs.: No cálculo desses valores, foram desconsideradas 3 crianças com sobressaliência } \\
\text { negativa. }\end{array}$
\end{tabular}

Estes resultados estão de acordo com Ravn (1976) que verificou que a prevalência da sobressaliência entre 0 e $2 \mathrm{~mm}$ foi maior nas crianças que nunca sugaram chupeta e similares com os de Farsi et al. (1997) que constataram que $50 \%$ das crianças com hábito de sugar chupeta apresentavam sobressaliência igual a ou maior que $4 \mathrm{~mm}$.

A maioria dos autores relatou que a média de sobressaliência para as crianças que sugavam chupeta era maior do que as que não tinham este hábito (Bowden,1966b; Adair et al., 1992; Adair et al., 1995) o que reafirma os resultados obtidos neste estudo.

Adair et al. (1992) constataram diferença estatisticamente significante entre a média de sobressaliência das crianças que sugavam chupeta anatômica $(3,04 \mathrm{~mm})$ quando comparadas `as que sugavam chupeta convencional (2,63 mm) ou não tinham este hábito $(2,12 \mathrm{~mm})$.

Por outro lado, os resultados deste estudo confirmam também aqueles encontrados por Adair et al. (1995) que não verificaram diferença na 
média da sobressaliência entre o grupo das crianças que utilizava chupeta convencional $(2,2 \mathrm{~mm})$ ou anatômica $(2,5 \mathrm{~mm})$.

Quanto àsobremordida, os Testes de Independência mostraram que houve uma relação significante entre esta variável $(p=0,001)$ e o uso e tipo de chupeta (Tabela 5.22).

Encontrou-se que a mordida aberta anterior estava presente somente nas crianças que tinham o hábito de sugar a chupeta. Constatou-se alteração de sobremordida em $50 \%$ das crianças do grupo da chupeta convencional e da anatômica. A sobremordida caracterizada por mais que $50 \%$ de trespasse vertical foi observada em $20,0 \%$ das crianças que utilizavam a chupeta anatômica, 29,6\% das crianças que não tinham hábito de sucção de chupeta e $7,1 \%$ no grupo da chupeta convencional (Figura 21).

Houve diferença na presença de mordida aberta anterior entre as crianças que sugavam chupeta convencional ou anatômica e aquelas que não tinham este hábito; porém, não houve diferença entre as crianças que usavam tanto a chupeta convencional ou anatômica (Tabela 5.30). 


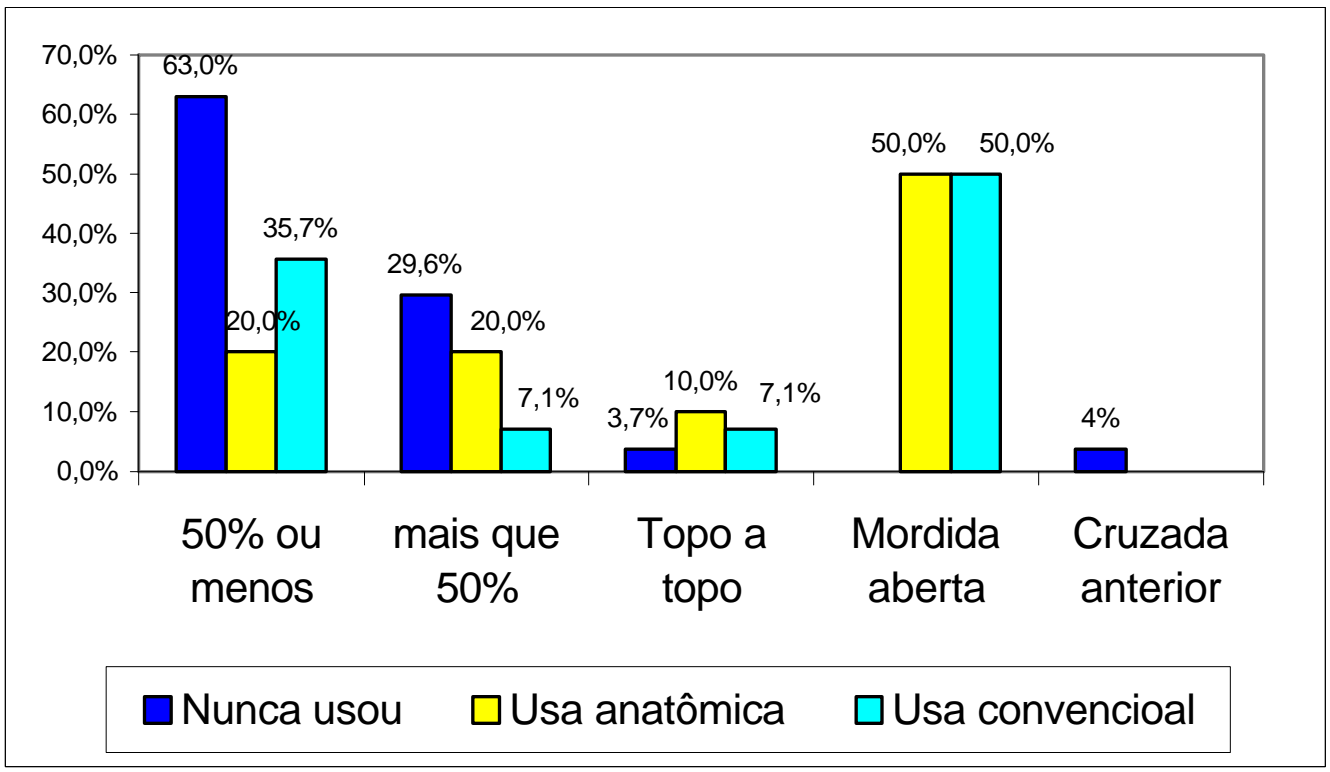

Figura 21 - Distribuição percentual da variável "Sobremordida" segundo o uso e tipo de chupeta

TABELA 5.30 - Intervalos de confiança para as diferenças entre as probabilidades de mordida aberta anterior com coeficiente de confiança global de $95 \%$

\begin{tabular}{|c|c|c|c|c|c|}
\hline Diferença & $\begin{array}{c}\text { Estimativa } \\
\text { da diferença }\end{array}$ & $\begin{array}{c}\text { Estatística } \\
\mathrm{z}\end{array}$ & $\begin{array}{c}\text { Erro } \\
\text { padrão da } \\
\text { estimativa }\end{array}$ & $\begin{array}{c}\text { Limite } \\
\text { inferior do } \\
\text { intervalo }\end{array}$ & $\begin{array}{l}\text { Limite superior } \\
\text { do intervalo }\end{array}$ \\
\hline$\underline{P(M A \mid N U)-P(M A \mid U O)}$ & $-0,500$ & 2,394 & 0,112 & $-0,768$ & $-0,232$ * \\
\hline$P(M A \mid N U)-P(M A \mid U C)$ & $-0,500$ & 2,394 & 0,134 & $-0,820$ & $-0,180$ * \\
\hline$\underline{P(M A \mid U O)-P(M A \mid U C)}$ & 0,000 & 2,394 & 0,174 & $-0,417$ & 0,417 \\
\hline
\end{tabular}

* Estatisticamente significante

Obs: $\mathrm{P}(\mathrm{MA} \mid \mathrm{NU})=$ probabilidade de mordida aberta, dado que a criança nunca usou chupeta;

$\mathrm{P}(\mathrm{MA} \mid \mathrm{UO})=$ probabilidade de mordida aberta, dado que a criança usa chupeta anatômica;

$\mathrm{P}(\mathrm{MA} \mid \mathrm{UC})=$ probabilidade de mordida aberta, dado que a criança usa chupeta convencional. 
Diversos autores também observaram que a prevalência de mordida aberta anterior era significativamente maior nas crianças que tinham hábito de sucção de chupeta quando comparadas ষ̀vuelas que não a usavam (Bowden, 1966a; Larsson, 1975; Ravn, 1976; Lindstein et al., 1986; Silva Filho et al., 1991; Adair et al., 1992; Paunio et al., 1993; Larsson, 1994; Adair et al., 1995; Chan et al., 1996; Farsi et al., 1997; Serra-Negra et al., 1997).

Outros autores apenas mencionavam a relação entre mordida aberta anterior e hábito de sugar a chupeta (Myllärniemi, 1973; Larsson, 1986; Dadalto, 1989; Silva Filho et al., 1991; Larsson, 1994; Chan et al., 1996; Monguilhott, 1986)

Ao contrário dos resultados obtidos neste estudo, Adair et al. (1992) e Adair et al. (1995) encontraram uma prevalência maior de mordida aberta anterior nas crianças que sugavam chupeta convencional $(29,6 \%$ e $23,7 \%)$ do que nas crianças que não sugavam chupeta $(4,0 \%$ e $3,1 \%)$, ou sugavam a anatômica $(14,8 \%$ e 13,4\%), respectivamente.

Para verificar a significância entre a dimensão da mordida aberta anterior, em milímetros, presente nas crianças que usavam chupeta, foi realizada a Análise de Variância. Encontrou-se que não houve relação significante, $\mathrm{p}=0,344$ (Anexo B). Logo, o uso da chupeta tanto convencional como anatômica, favoreceram o desenvolvimento da mordida aberta anterior.

A Tabela 5.31 apresenta a estatística descritiva da dimensão da mordida aberta segundo o tipo de chupeta utilizada. Observou-se que a média da mordida aberta foi semelhante nas crianças que sugavam chupeta, porém, a 
mediana foi menor naquelas que sugavam a chupeta anatômica $(5,0 \mathrm{~mm})$ do que naquelas que sugavam a convencional $(8,00 \mathrm{~mm})$.

TABELA 5.31- Estatística descritiva da variável "Quanto de mordida aberta (em milímetros)" segundo a variável "Tipo de chupeta"

\begin{tabular}{cccccccc}
\hline Tipo de chupeta & $\mathrm{n}$ & Média & $\begin{array}{r}\text { Desvio } \\
\text { Padrão }\end{array}$ & Mínimo & Máximo & Mediana \\
\hline Usa anatômica & 10 & 5,2 & 3,01 & 1,0 & 10,0 & 5,0 \\
Usa convencional & 7 & 6,5 & 2,14 & 3,0 & 8,5 & 8,0 \\
\hline
\end{tabular}

A média de mordida aberta anterior constatada por Adair et al. (1995) para as crianças que sugavam chupeta convencional $(2,6 \mathrm{~mm})$ ou chupeta anatômica $(2,9 \mathrm{~mm})$ foi menor daquela encontrada no presente estudo, $\quad 6,5 \mathrm{~mm}$ e 5,2 mm, respectivamente. Porém, em ambos estudos não houve diferença entre os sugadores de chupeta convencional ou anatômica e a dimensão da mordida aberta anterior.

A Análise de Variância mostrou haver diferença entre os três grupos para distância intercanina do arco superior com referência na ponta da cúspide $(p=0,004)$ e na distância intercanina do arco superior referente àcervical $(p=0,016) \quad($ Anexo B) .

A distância intercanina do arco superior com referência na ponta da cúspide foi significantemente diferente entre as crianças que nunca usaram chupeta e aquelas que a usavam, não havendo diferença entre os dois tipos de chupetas (Tabelas 5.32 e 5.33). 
Estes resultados estão de acordo com aqueles encontrados por Bowden (1966b) e mencionados por Larsson (1994) nos quais a distância intercanina do arco superior foi menor nas crianças com hábito de sugar chupeta do que naquelas sem o hábito.

TABELA 5.32 - Intervalos de confiança de Bonferroni para a variável "Distância intercanina do arco superior - Ponta da cúspide (em milímetros)" com coeficiente de confiança global de $95 \%$

\begin{tabular}{ccccc} 
Uso e tipo de chupeta (I) & $\begin{array}{c}\text { Uso e tipo de } \\
\text { chupeta (J) }\end{array}$ & $\begin{array}{c}\text { Diferença } \\
\text { entre as } \\
\text { médias (I-J) }\end{array}$ & $\begin{array}{c}\text { Limite } \\
\text { inferior }\end{array}$ & $\begin{array}{c}\text { Limite } \\
\text { superior }\end{array}$ \\
\hline Nunca usou & Usa anatômica & 1,672 & 0,191 & $3,153^{*}$ \\
Nunca usou & Usa convencional & 2,008 & 0,355 & $3,661^{*}$ \\
Usa anatômica & Usa convencional & 0,336 & $-1,414$ & 2,085 \\
\hline
\end{tabular}

Estatisticamente significante

TABELA 5.33 - Estatística descritiva da variável "Distância intercanina do arco superior - Ponta da cúspide (em milímetros)" segundo a variável "Uso e tipo de chupeta"

\begin{tabular}{ccccccc}
\hline $\begin{array}{c}\text { Uso e tipo de } \\
\text { chupeta }\end{array}$ & $\mathrm{n}$ & Média & $\begin{array}{c}\text { Desvio } \\
\text { Padrão }\end{array}$ & Mínimo & Máximo & Mediana \\
\hline Nunca usou & 27 & 31,2 & 1,77 & 28,0 & 34,0 & 31,0 \\
Usa anatômica & 20 & 29,6 & 2,54 & 23,5 & 33,0 & 29,8 \\
Usa convencional & 14 & 29,2 & 1,67 & 25,5 & 31,5 & 29,0 \\
\hline
\end{tabular}


A primeira vista, a distância intercanina do arco superior foi muito semelhante entre os três grupos avaliados; porém, como observado anteriormente, a análise estatística mostrou diferença entre o grupo de crianças que nunca usou chupeta e aquelas que tinham o hábito de sugar a chupeta. Isto pode ser explicado pelo baixo e similar desvio padrão existente entre os grupos e portanto pôde-se detectar diferenças tão pequenas.

Quando se considerou a distância intercanina do arco superior, usando como referência a área cervical, encontrou-se que houve diferença significante apenas entre as crianças que usavam chupeta convencional e aquelas que nunca tinham usado chupeta (Tabela 5.34 e 5.35).

TABELA 5.34 - Intervalos de confiança de Bonferroni para a variável "Distância intercanina do arco superior - cervical (em milímetros)" com coeficiente de confiança global de $95 \%$

\begin{tabular}{ccccc}
\hline Uso e tipo de chupeta $(\mathrm{I})$ & $\begin{array}{c}\text { Uso e tipo de } \\
\text { chupeta }(\mathrm{J})\end{array}$ & $\begin{array}{c}\text { Diferença entre } \\
\text { médias }(\mathrm{I}-\mathrm{J})\end{array}$ & $\begin{array}{c}\text { Limite } \\
\text { inferior }\end{array}$ & $\begin{array}{c}\text { Limite } \\
\text { superior }\end{array}$ \\
\hline Nunca usou & Usa anatômica & 0,670 & $-0,610$ & 1,951 \\
Nunca usou & Usa convencional & 1,728 & 0,298 & $3,157^{*}$ \\
Usa anatômica & Usa convencional & 1,057 & $-0,455$ & 2,569 \\
\hline
\end{tabular}

* Estatisticamente significante

TABELA 5.35 - Estatística descritiva da variável "Distância intercanina do arco superior - cervical (em milímetros)" segundo a variável "Uso e tipo de chupeta"

\begin{tabular}{ccccccc}
\hline $\begin{array}{c}\text { Uso e tipo de } \\
\text { chupeta }\end{array}$ & $\mathrm{n}$ & Média & $\begin{array}{c}\text { Desvio } \\
\text { Padrão }\end{array}$ & Mínimo & Máximo & Mediana \\
\hline Nunca usou & 27 & 25,4 & 1,58 & 22,0 & 28,0 & 25,5 \\
Usa anatômica & 20 & 24,7 & 2,12 & 20,0 & 29,0 & 24,5 \\
Usa convencional & 14 & 23,6 & 1,50 & 22,0 & 27,0 & 23,8 \\
\hline
\end{tabular}


Ao contrário do que alguns autores mencionaram (Larsson, 1986; Larsson, 1994; Øgaard et al., 1994), as médias das distâncias intercaninas do arco inferior ao nível de ponta da cúspide foram praticamente iguais em todos os grupos: $25,2 \mathrm{~mm}$ nas crianças que nunca sugaram ou sugavam a chupeta convencional e $25,6 \mathrm{~mm}$ a chupeta anatômica. O mesmo padrão ocorreu na distância intercanina do arco inferior ao nível cervical: 20,4 mm para o grupo que nunca sugou chupeta, $20,5 \mathrm{~mm}$ para o da chupeta convencional, e 20,8 $\mathrm{mm}$ para o da anatômica (Anexo B).

Em seu estudo longitudinal sobre a largura dos arcos dentais, Knott (1972) mediu a distância intercanina dos arcos ao nível cervical em crianças com 5,4 anos de idade, em média. A autora encontrou no arco superior dos meninos uma distância intercanina média de $35,5 \mathrm{~mm}$ e nas meninas de $33,6 \mathrm{~mm}$. No arco inferior, a média da distância intercanina foi de $28,5 \mathrm{~mm}$ para os meninos e $27,0 \mathrm{~mm}$ para as meninas.

Usberti et al. (1985) também utilizaram como ponto de referência a região cervical dos caninos. Encontraram que a distância intercanina média no arco superior de crianças com arco tipo I de Baume foi de 23,38 mm e no arco tipo II de 22,68 mm. No arco inferior, os valores médios foram: 19,01 mm e $18,37 \mathrm{~mm}$, respectivamente. Estes resultados são os mais semelhantes \&̀yueles encontrados no presente estudo.

Coloma et al. (1985) utilizaram a ponta da cúspide do canino do arco superior para esta medição. Os autores encontraram distâncias intercaninas médias para os meninos de $30,5 \mathrm{~mm}$ e, $29,5 \mathrm{~mm}$ para as meninas. 
Bishara et al. (1997), assim como Coloma et al. (1985) tomaram como ponto de referência a ponta da cúspide do canino para realizar a medição da distância intercanina. Observaram que aos três anos de idade, a média da distância intercanina do arco superior nos meninos foi de $28,8 \mathrm{~mm}$ e nas meninas de 27,4 mm. Aos cinco anos de idade, estas dimensões estavam um pouco aumentadas, $30,3 \mathrm{~mm}$ e $28,4 \mathrm{~mm}$, respectivamente. Já no arco inferior, as médias encontradas aos 3 anos de idade foi $22,1 \mathrm{~mm}$ entre os meninos $\mathrm{e}$ 21,5 mm entre as meninas; e aos cinco anos de idade, a média foi 23,4 mm para os meninos e $22,3 \mathrm{~mm}$ para as meninas.

Observa-se que houve grande variação na dimensão das distâncias intercaninas dos arcos dentais verificadas pelos diversos autores, e isto pode ser explicado pela diversidade existente entre as populações avaliadas.

Segundo Larsson (1994) e Øgaard et al., (1994), o efeito do uso prolongado da chupeta é uma diminuição na distância intercanina do arco superior e aumento desta no arco inferior, devido àposição mais infe riorizada da língua na cavidade bucal quando da sucção da chupeta. Associado a isto, foi constatado por Lindner \& Helssing (1991) que a pressão média (em gramas por centímetro $^{2}$ ) do lábio e bochecha na região dos caninos decíduos foi 3,4 vezes maior do que na região dos segundos molares decíduos.

Øgaard et al. (1994), ressaltaram ainda, que um dos fatores mais influentes no desenvolvimento da mordida cruzada posterior foi a diferença entre as distâncias intercaninas dos arcos superior e inferior. Assim, quanto menor a diferença entre a distância do arco superior e a do inferior, maior o risco de desenvolver mordida cruzada posterior. Neste mesmo raciocínio, Larsson 
(1994) alertou para o fato que o risco torna-se alto quando esta diferença é menor que $3 \mathrm{~mm}$.

Vários autores relataram que as alterações nos arcos dentais provocadas por hábitos de sucção não nutritivos dependem da intensidade, freqüência e duração deste hábito (Bacchi, 1973; Ravn, 1976; Black et al., 1990; Proffit, 1986; Camargo et al., 1998).

Assim, verificou-se, também, se o modo de sugar a chupeta ("suga

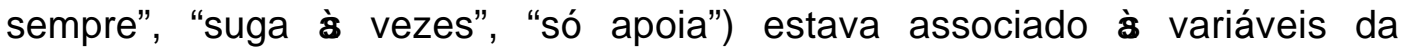
avaliação dos arcos dentais. Pela análise da Tabela 5.35, verifica-se que não houve relação do modo do uso da chupeta com o desvio de linha média, relação canina, mordida cruzada posterior e sobremordida.

Estes resultados são contrários æ̀uveles apresentados por Modéer et al. (1982) que verificaram que a prevalência de mordida cruzada posterior aumentava com o aumento da intensidade do uso da chupeta.

TABELA 5.36 - Testes de Independência (Qui-quadrado de Pearson) entre as variáveis da avaliação dos arcos dentais e a variável "Como suga"

\begin{tabular}{lcc}
\hline \multicolumn{1}{c}{$\begin{array}{c}\text { Variável da avaliação } \\
\text { dos arcos dentais }\end{array}$} & $\begin{array}{c}\text { Valor da estatística } \\
\text { Qui-quadrado de } \\
\text { Pearson }\end{array}$ & $\begin{array}{c}\text { Nível descritivo } \\
\text { exato }\end{array}$ \\
\hline Desvio de linha média & 2,922 & 0,586 \\
Relação canina lado direito & 4,725 & 0,100 \\
Relação canina lado esquerdo & 3,579 & 0,271 \\
Mordida cruzada posterior & 3,370 & 1,000 \\
Sobremordida & 5,231 & 0,557 \\
\hline
\end{tabular}


Analisando as Tabelas 5.37 e 5.38 , observa-se que houve uma associação entre a quantidade de sobressaliência nas crianças que sugavam sempre e aquelas que sugavam ̀̀ vezes, sendo maior nas crianças que sugavam sempre.

TABELA 5.37 - Análise de Variância para a variável "Sobressaliência (milímetros)", com fator "Como suga"

\begin{tabular}{cccccc}
\hline Fonte de variação & $\begin{array}{c}\text { Soma de } \\
\text { quadrados }\end{array}$ & $\begin{array}{c}\text { Graus de } \\
\text { liberdade }\end{array}$ & $\begin{array}{c}\text { Quadrado } \\
\text { médio }\end{array}$ & $\mathrm{F}$ & $\begin{array}{c}\text { Nível } \\
\text { descritivo } \\
(\mathrm{p})\end{array}$ \\
\hline Como suga & 24,582 & 2 & 12,291 & 4,452 & $0,021^{*}$ \\
Resíduo & 80,065 & 29 & 2,761 & & \\
\hline Total & 104,647 & 31 & & & \\
\hline
\end{tabular}

* Estatisticamente significante

Obs.: Foram desconsideradas as crianças com sobressaliência negativa

TABELA 5.38 - Intervalos de confiança de Bonferroni para a variável "Sobressaliência (milímetros)" com coeficiente de confiança global de 95\%

\begin{tabular}{|c|c|c|c|c|}
\hline Modo de sugar (I) & Modo de sugar (J) & $\begin{array}{c}\text { Diferença } \\
\text { entre as } \\
\text { médias (I-J) }\end{array}$ & $\begin{array}{l}\text { Limite } \\
\text { inferior }\end{array}$ & Limite superior \\
\hline Suga sempre & Suga à vezes & 2,044 & 0,404 & 3,684 * \\
\hline Suga sempre & Apoia & 1,462 & $-1,390$ & 4,313 \\
\hline Suga à vezes & Apoia & $-0,582$ & 3,370 & 2,206 \\
\hline
\end{tabular}

* Estatisticamente significante 
O presente estudo obteve resultados similares, pelo menos em um aspecto, ঐ̀ueles mencionados e esperados por Bacchi (1973) que descreveu que os efeitos dos hábitos sobre a oclusão dental se tornam mais pronunciados quanto mais intensos, prolongados e repetitivos eles se apresentam.

Adair et al. (1995) observaram relação significante entre a duração do hábito e maloclusões nos planos verticais e transversais.

No entanto, Chan et al. (1996) constataram que a freqüência do hábito não foi fator significante no agravamento das alterações dento-alveolares por eles observadas (sobressaliência e sobremordida).

Adair et al. (1992;1995) não encontraram correlação entre a intensidade (hora de uso por dia) com maloclusões. Por outro lado, Modéer et al. (1982) verificaram que a freqüência de mordida cruzada posterior estava diretamente relacionada com a intensidade (horas de uso por dia) e duração do hábito de sucção não nutritivo.

Embora fosse esperada maior diferença entre o grupo que sugava sempre ou só apoiava a chupeta na boca, deve-se considerar que os dados obtidos no presente estudo, basearam-se apenas no relato das mães, o que nem sempre é de fácil avaliação. Além disso, não foi possível obter respostas conclusivas sobre o tempo de uso diário da chupeta, o que também poderia interferir nestes resultados, por que poucas mães souberam relatar a duração do hábito durante o dia, em horas. 


\subsection{Avaliação das estruturas miofuncionais orais}

Foi realizada a avaliação de algumas estruturas miofuncionais orais, pois a avaliação das funções como a deglutição e fala é bastante difícil nesta faixa etária. Assim, optou-se por examinar o aspecto, tonicidade e mobilidade de algumas estruturas anatômicas importantes envolvidas na sucção, além de observar a simetria facial.

TABELA 5.39 - Testes de Independência (Qui-quadrado de Pearson) entre as variáveis da avaliação estruturas miofuncionais orais e a variável "Uso e tipo de chupeta"

\begin{tabular}{lcc}
\hline $\begin{array}{l}\text { Variável da avaliação das } \\
\text { estruturas miofuncionais orais }\end{array}$ & $\begin{array}{c}\text { Valor da estatística } \\
\text { Qui-quadrado de } \\
\text { Pearson }\end{array}$ & $\begin{array}{c}\text { Nível descritivo } \\
\text { exato }(p)\end{array}$ \\
\hline Lábios - Aspecto & 9,236 & 0,772 \\
Lábios - Tonicidade & 12,955 & 0,083 \\
Lábios - Mobilidade & 2,764 & 0,272 \\
Língua - Aspecto & 2,604 & 0,345 \\
Língua - Tonicidade & 0,034 & 1,000 \\
Língua - Mobilidade & 0,639 & 0,773 \\
Bochecha - Tonicidade & 1,238 & 0,623 \\
Bochecha - Mobilidade & $\mathbf{1 1 , 0 3 1}$ & $\mathbf{0 , 0 2 2 *}$ \\
Simetria facial & 6,058 & $\mathbf{0 , 4 3 4}$ \\
Palato duro & $\mathbf{1 2 , 4 3 0}$ & $\mathbf{0 , 0 4 2 *}$ \\
\hline
\end{tabular}

* Estatisticamente significante

Pode-se notar que, apenas em relação àmobilidade da bochecha e formato do palato duro houve diferença estatisticamente significante entre os três grupos. 
A mobilidade da bochecha estava normal em $74,1 \%$ das crianças que não tinham hábito de sucção de chupeta, 35,7\% daquelas que sugavam a chupeta convencional e 35,0\% a anatômica (Figura 22).

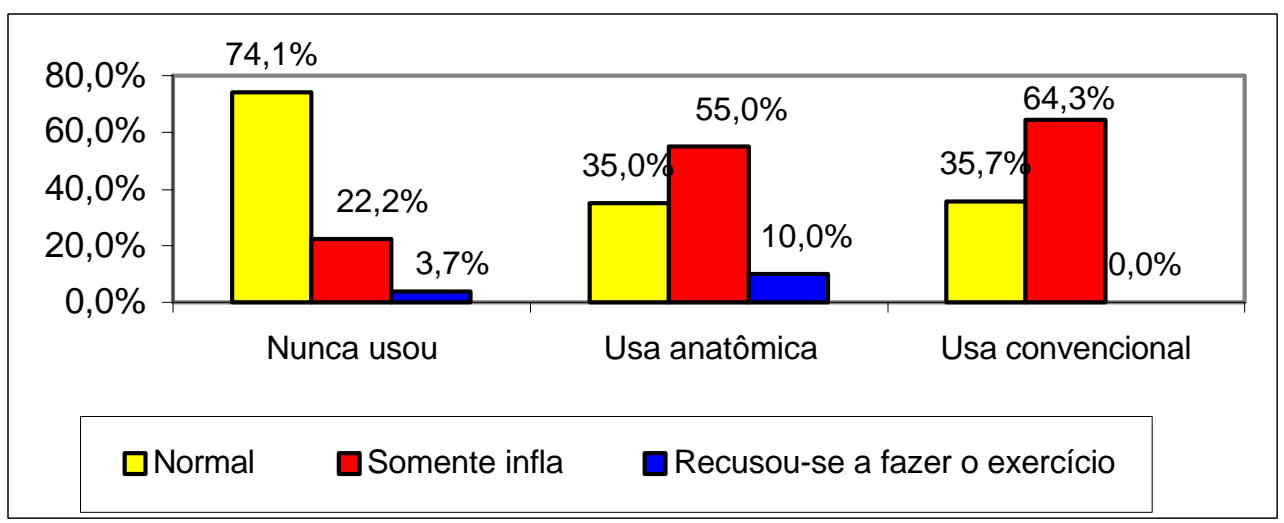

Figura 22 - Distribuição da freqüência de mobilidade da bochecha segundo o uso e tipo de chupeta

Verificou-se que a probabilidade de mobilidade normal da bochecha foi significantemente maior entre as crianças que nunca usaram chupeta do que entre aquelas que usavam, tanto a convencional quanto a anatômica. Além disso, pode-se observar que não houve diferença significante entre as probabilidades de mobilidade normal nas crianças que usavam chupeta convencional e naquelas que usavam a anatômica (Tabela 5.40). 
TABELA 5.40 - Intervalos de confiança para as diferenças entre as probabilidades de normal na variável "Bochecha - mobilidade", com coeficiente de confiança global de $95 \%$

\begin{tabular}{|c|c|c|c|c|c|}
\hline Diferença & $\begin{array}{c}\text { Estimativa } \\
\text { da } \\
\text { diferença }\end{array}$ & $\begin{array}{c}\text { Estatística } \\
z\end{array}$ & $\begin{array}{c}\text { Erro } \\
\text { padrão da } \\
\text { estimativa }\end{array}$ & $\begin{array}{c}\text { Limite } \\
\text { inferior do } \\
\text { intervalo }\end{array}$ & $\begin{array}{c}\text { Limite } \\
\text { superior do } \\
\text { intervalo }\end{array}$ \\
\hline$P(N \mid N U)-P(N \mid U O)$ & 0,391 & 2,394 & 0,136 & 0,065 & 0,716 * \\
\hline$P(N \mid N U)-P(N \mid U C)$ & 0,384 & 2,394 & 0,153 & 0,017 & 0,751 * \\
\hline$P(N \mid U O)-P(N \mid U C)$ & $-0,007$ & 2,394 & 0,167 & $-0,406$ & 0,392 \\
\hline
\end{tabular}

* Estatisticamente significante

Obs: $\mathrm{P}(\mathrm{N} \mid \mathrm{NU})=$ probabilidade mobilidade normal, dado que a criança nunca usou chupeta;

$\mathrm{P}(\mathrm{N} \mid \cup O)=$ probabilidade de mobilidade normal, dado que a criança usa chupeta anatômica;

$\mathrm{P}(\mathrm{N} \mid \mathrm{UC})=$ probabilidade de mobilidade normal, dado que a criança usa chupeta convencional.

Ahlgren (1995) observou atividade do músculo bucinador (bochecha) menos evidente do que do lábio e mentalis nas crianças que sugavam chupeta. Por outro lado, comparando as atividades musculares de lábios e bochechas entre as crianças com hábito de sucção de dedo ou de chupeta, o autor encontrou que estas foram mais evidentes no grupo que utilizava a chupeta.

Uma das principais funções das bochechas é auxiliar durante a mastigação, mantendo o alimento sobre os dentes, por meio de movimentos contrários aos da língua. Quando se observa que as bochechas estão "caídas", geralmente sua função está diminuída. Nestes casos, ocorre o acúmulo de restos alimentares no vestíbulo lateral (Marchesan, 1993).

Observa-se que as alterações na atividade muscular encontradas, vêm de encontro ao que foi mencionado anteriormente sobre o 
equilíbrio necessário no sistema estomatognático e sua interação com as funções bucais.

Também foi constatada diferença significante no que se refere ao palato duro. No grupo de crianças que sugava a chupeta convencional, a proporção de palato duro normal foi bem menor $(35,7 \%)$ do que nos demais grupos, $77,8 \%$ e 75,0\%, para grupo sem hábito de sucção e grupo da chupeta anatômica, respectivamente (Figura 23).

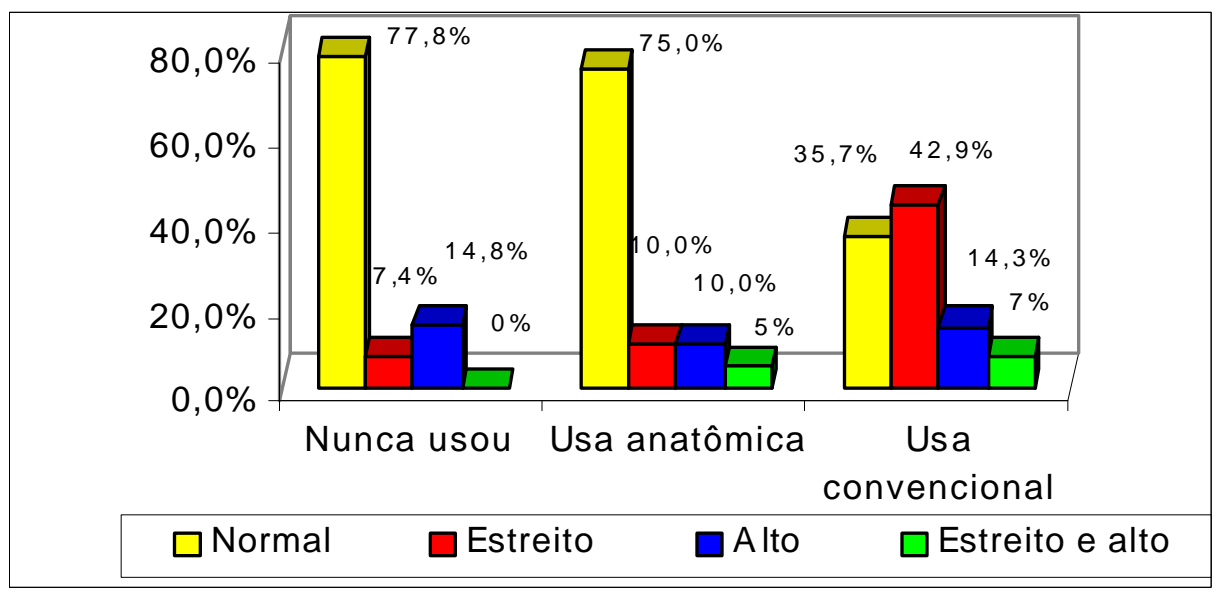

Figura 23 - Distribuição da freqüência relativa do formato do palato duro segundo o tipo e uso de chupeta

A Tabela 5.41 mostra que não houve diferença significante quanto a probabilidade de palato duro normal entre as crianças que nunca usaram chupeta, e as que usavam as chupetas anatômicas. Por outro lado, a probabilidade de palato duro normal foi significantemente maior entre estas crianças do que entre as que usavam a convencional. 
TABELA 5.41 - Intervalos de confiança para as diferenças entre as probabilidades de Normal na variável "Palato duro", com coeficiente de confiança global de $95 \%$

\begin{tabular}{lccccc}
\hline Diferença & $\begin{array}{c}\text { Estimativa } \\
\text { da diferença }\end{array}$ & $\begin{array}{c}\text { Estatística } \\
z\end{array}$ & $\begin{array}{c}\text { Erro } \\
\text { padrão da } \\
\text { estimativa }\end{array}$ & $\begin{array}{c}\text { Limite } \\
\text { inferior do } \\
\text { intervalo }\end{array}$ & $\begin{array}{c}\text { Limite } \\
\text { superior do } \\
\text { intervalo }\end{array}$ \\
\hline$P(N \mid N U)-P(N \mid \cup O)$ & 0,028 & 2,394 & 0,126 & $-0,273$ & 0,328 \\
$P(N \mid N U)-P(N \mid \cup C)$ & 0,421 & 2,394 & 0,151 & 0,059 & 0,782 * \\
$P(N \mid \cup O)-P(N \mid \cup C)$ & 0,393 & 2,394 & 0,161 & 0,009 & $0,777^{*}$ \\
\hline
\end{tabular}

* estatisticamente significante

Obs: $\mathrm{P}(\mathrm{N} \mid \mathrm{NU})$ = probabilidade palato duro normal, dado que a criança nunca usou chupeta;

$\mathrm{P}(\mathrm{N} \mid \mathrm{UO})=$ probabilidade de palato duro normal, dado que a criança usa chupeta anatômica;

$\mathrm{P}(\mathrm{N} \mid \mathrm{UC})=$ probabilidade de palato duro normal, dado que a criança usa chupeta convencional.

A associação entre o formato de palato duro ogival e o hábito de sucção foi mencionada por Black et al., 1990; Gomes et al., 1993; Marchesan, 1993; e Soares \& Totti, 1996. A explicação disto seria a posição mais inferiorizada da língua quando da sucção de chupeta (Marchesan, 1993) associada ao fato do bico da chupeta encaixar-se no palato duro e ser empurrado pelo dorso língua (Gomes et al., 1993).

O formato do palato duro está associado àlargura transversal do arco dental; portanto, se a largura deste torna-se menor, o palato ficará mais estreito. Isto já foi mencionado anteriormente, ao discutir as distâncias intercaninas do arco superior e o mecanismo pelo qual há uma diminuição nesta distâncias naquelas crianças que sugavam chupeta.

Ao inserir o bico da chupeta na cavidade bucal, este ocupa o espaço funcional da boca, deslocando a língua, afastando lábios e rebordo (Modesto et al., 1999). Camargo et al. (1998) destacaram que a chupeta 
ortodôntica ou anatômica, que tem bico mais achatado que a convencional, evita um distanciamento maior dos lábios e a inclinação do bico para cima, permitindo, desta maneira, um melhor posicionamento da língua.

Tanto o aspecto do lábio como a tonicidade apresentaram comportamento semelhantes nos três grupos avaliados como pôde ser visto na Tabela 5.42. Das crianças que nunca usaram chupeta, 70,4\% apresentavam aspecto de lábios normais; das que utilizavam chupeta anatômica, 45,0\% e da convencional, 50,0\%. As crianças que utilizavam a chupeta anatômica, as alterações do aspecto do lábio mais prevalentes foram de vermelhão aparente em conjunto com lábios entreabertos (15,0\%), posição alternada (15,0\%), e somente lábios entreabertos (10,0\%). Naquelas que sugavam chupeta convencional, a presença de lábios entreabertos foi a mais prevalecente $(21,4 \%)$. Estes resultados mostraram uma certa tendência das crianças sem hábito de sucção de chupeta apresentarem maior prevalência de normalidade quanto ao aspecto do lábio, do que aquelas que sugavam chupetas, tanto anatômicas como convencionais .

Embora a tonicidade labial não tenha sido estatisticamente significante, houve uma tendência de maior proporção de tônus normal, no grupo de crianças que nunca usou chupeta. Mais da metade $(74,1 \%)$ destas crianças apresentou tonicidade de lábios normal, contra 55,0\% do grupo da chupeta anatômica e 42,9\% da chupeta convencional. O aspecto de hipotonicidade do lábio superior foi a alteração mais prevalente no grupo que utilizava a chupeta convencional (28,6\%). A hipotonicidade de ambos os lábios foi encontrado em $25,0 \%$ das crianças que utilizavam chupeta 
anatômica, $14,3 \%$ da chupeta convencional e 15,0\% do grupo sem hábito de sucção de chupeta (Tabela 5.43).

A tonicidade da bochecha foi constatada como normal em $77,8 \%$ das crianças que nunca sugaram chupeta, contra $65,0 \%$ das que usavam a chupeta anatômica e $64,3 \%$ daquelas que sugavam a convencional. Esta diferença não foi estatisticamente significante, mas mostrou uma certa tendência que da hipotonicidade de bochecha ser menor nas crianças que não tinham hábito de sucção de chupeta (Figura 24).

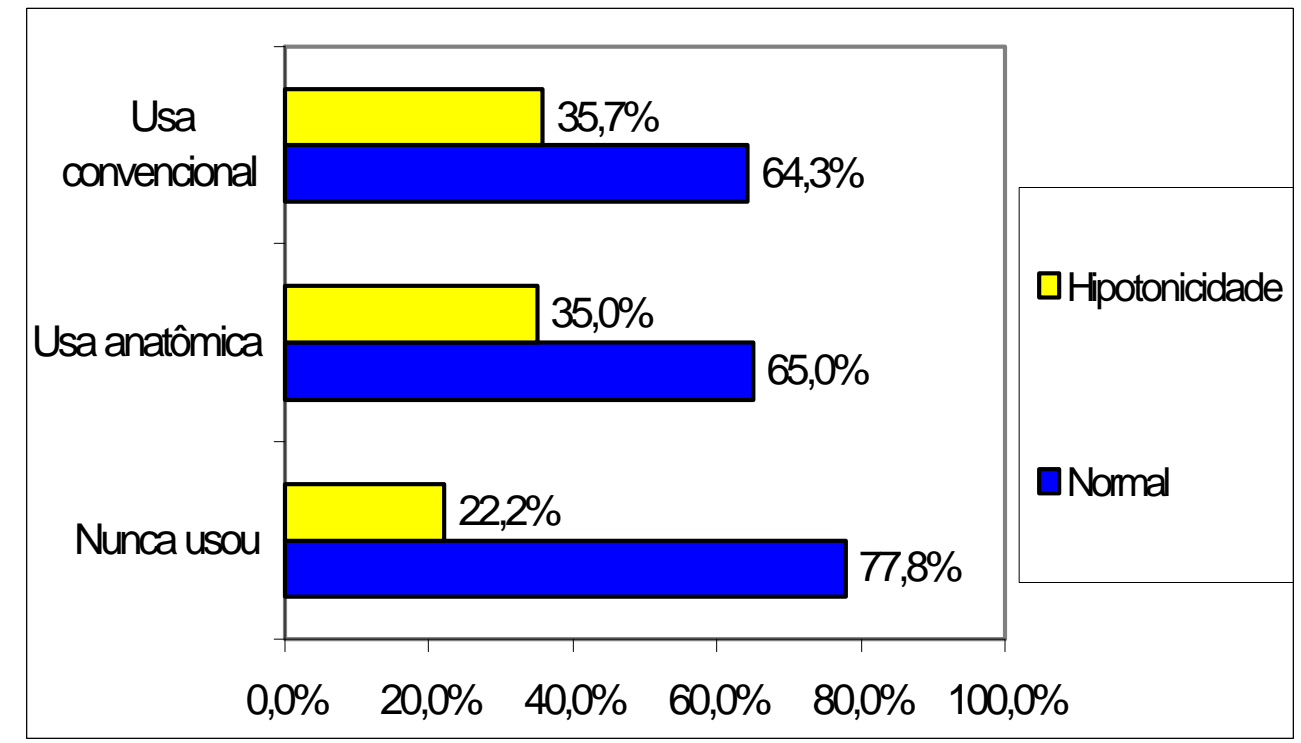

Figura 24 - Distribuição da freqüência relativa da variável "Tonicidade da bochecha" segundo o uso e tipo de chupeta" 
Segundo Carvalho (1997), alterações nas funções da boca como: mastigação, respiração, sucção e deglutição podem desencadear distúrbios na oclusão dentária, fala e musculatura. Isto por que a forma do arco dental depende do equilíbrio entre os tecidos moles que o circundam. Quando há alteração em uma das funções da cavidade bucal, as demais sofrem desvios. Portanto, é muito difícil que o paciente apresente um único mau hábito bucal.

Os autores foram unânimes ao afirmar a associação existente entre hábitos deletérios de sucção e alterações na musculatura perioral e funções como: deglutição, respiração, sucção, fala e mastigação (Black et al., 1990; Dadalto, 1989; Soares \& Totti, 1996; Carvalho, 1997).

Especificamente em relação aos lábios, os autores consultados mencionaram que o hábito de sugar a chupeta favorece a posição de lábios entreabertos na posição de repouso (Dadalto, 1989; Soares e Totti, 1996); hipotonicidade (Black et al., 1990; Carvalho, 1997; Gomes et al., 1993); incompetência labial (Bowden, 1966a; Black et al., 1990; Gomes et al., 1983; Adair, 1996; Camargo et al.,1998; Gimenez et al., 2000) e hipofunção (Gomes et al., 1983).

Os lábios apresentam-se hipotônicos devido a postura adquirida durante a sucção inadequada (Carvalho, 1997). O uso de chupeta por período prolongados impede o contato dos lábios, levando a um desvio na direção de crescimento e ocupando o espaço funcional da língua (Camargo et al., 1998). 
Os resultados obtidos estão de acordo com a literatura, uma vez que apresentaram uma maior tendência de não normalidade do tônus muscular dos lábios entre as crianças que tinham o uso da chupeta quando comparadas \$̀ crianças que nunca sugaram chupeta.

Embora diversos autores também relataram a associação entre as alterações da musculatura da língua e o hábito de sugar chupeta (Bowden 1966a; Black et al., 1990; Marchesan, 1993; Gomes et al., 1993; Soares \& Totti, 1996; Adair, 1996; Camargo et al., 1998), isto não foi encontrada no presente estudo.

Assim como foi realizado na avaliação dos arcos dentais, julgouse de interesse avaliar o efeito do modo do uso da chupeta com relação as estruturas miofuncionais orais. Não se observou diferença significante para nenhuma das variáveis examinadas (Tabela 5.44).

TABELA 5.44 - Testes de Independência (Qui-quadrado de Pearson) entre as variáveis da avaliação das estruturas miofuncionais orais e a variável "Como suga"

\begin{tabular}{lcc}
\hline $\begin{array}{c}\text { Variável da avaliação } \\
\text { das } \begin{array}{c}\text { estruturas } \\
\text { miofuncionais orais }\end{array}\end{array}$ & $\begin{array}{c}\text { Valor da } \\
\text { estatística Qui- } \\
\text { quadrado de } \\
\text { Pearson }\end{array}$ & $\begin{array}{c}\text { Nível descritivo exato } \\
(\mathrm{p})\end{array}$ \\
\hline Lábios - Aspecto & 13,354 & 0,215 \\
\hline Lábios - Tonicidade & 4,103 & 0,886 \\
\hline Lábios - Mobilidade & 0,583 & 0,863 \\
\hline Língua - Tonicidade & 1,062 & 0,681 \\
\hline Língua - Mobilidade & 1,062 & 0,681 \\
\hline Bochecha - Tonicidade & 2,389 & 0,312 \\
\hline Bochecha - Mobilidade & 2,487 & 0,708 \\
\hline Simetria facial & 13,886 & 0,065 \\
\hline Palato duro & 1,497 & 0,983 \\
\hline
\end{tabular}




\subsection{Considerações finais}

Existem no mercado, inúmeras opções de chupetas anatômicas (ortodônticas) e convencionais, nacionais e importadas, com grande variação de custo. Além destes dois tipos, existem também as chupetas "mistas", ou seja, aquelas que apresentam algumas características das chupetas anatômicas e outras das convencionais. Um exemplo destas são aquelas que apresentam o escudo da chupeta anatômica e o bico da comum. Muitas crianças iniciam a sucção não nutritiva com um tipo de chupeta, e depois mudam para outro. Estes foram alguns dos motivos encontrados que dificultaram a obtenção de uma amostra maior para o presente estudo.

Dentre as chupetas importadas ortodônticas ou anatômicas as mais comuns são as das marcas NUK ${ }^{\mathrm{TM}}$ e MAM $^{\mathrm{TM}}$ (Figura 25). O formato do bico é bem diferente entre elas, porém ambas apresentam escudo (apoio labial) ligeiramente curvo e voltado para a cavidade bucal com recorte na região do nariz e furos de ventilação. Estas características determinam a chupeta mais adequada, como mencionado por Camargo et al. (1998).

O desenho das chupetas anatômicas nacionais é muito similar ao das importadas no que diz respeito ao escudo. Contudo, as dimensões e formato de alguns dos bicos nacionais apresentam apenas leve semelhança dos importados. Das chupetas nacionais disponíveis atualmente no mercado, aquelas com desenho similar a marca MAM ${ }^{\mathrm{TM}}$ são as que mais se assemelham ̀̀ importadas. 
O diâmetro ou altura da base do bico das chupetas convencionais é maior do que os das anatômicas, tanto para as nacionais como para as importadas. O formato da base do bico das chupetas convencionais é redondo e o das anatômicas "elíptico". Segundo Camargo et al. (1998) o bico mais adequado é aquele mais achatado, por que evitaria o distanciamento maior dos lábios e a inclinação do bico para cima, e permitiria um melhor posicionamento da língua. Estas características somente são encontradas somente nas chupetas anatômicas.

O desenho do escudo das chupetas convencionais é muito diferente do das anatômicas, tanto em formato como em dimensão. Alguns autores mencionaram que a função do escudo é dar apoio a musculatura perioral durante a sucção da chupeta, fortalecendo os músculos orbiculares orais (Margolis, 1980) permitindo bom vedamento labial (Camargo et al., 1998).

Estamos de acordo com Moreira (1998), que afirmou que a chupeta deve ser utilizada de maneira disciplinada, nos casos dos bebês estarem irritados ou sonolentos após a mamada, e com Camargo (1998) ao mencionar que a chupeta deve ser oferecida quando a criança apresentar necessidade de sucção. O uso da chupeta não deve servir para consolo da criança ou para solucionar outros problemas como o susto, cólica, o fato de estar com fralda molhada ou se sentir sozinho.

Os profissionais da área da saúde que estão em freqüente contato com mães, crianças e mulheres, devem orientar e educar esta população para que não seja cometido o "abuso" do uso ou uso 
indiscriminado da chupeta e da mamadeira; pois desde 1963, Moffatt mencionava que os hábitos de sucção não nutritivos, podiam provocar alterações histológicas de reabsorção e aposição óssea, da mesma maneira que ocorrem quando da utilização de forças ortodônticas leves e lentas. Profitt (1986) completou esta idéia ao afirmar que a chupeta atua por pressão mecânica, movendo os dentes e modificando o crescimento maxilar. Comentou ainda, que para afetar o desenvolvimento da oclusão, o importante é a duração da força e não sua magnitude. Portanto, hábitos bucais mantidos por período prolongado (entre 4 e 6 horas diários), alteram a posição de descanso da língua e exercem pressão sobre os lábios.

No presente estudo, as chupetas anatômicas utilizadas pelas crianças eram, em menor número, importadas, ou nacionais. Talvez, se fossem separadas as crianças que sugavam chupetas anatômicas importadas daquelas que utilizavam as anatômicas nacionais, alguns dos resultados poderiam ter sido diferentes. Porém, Adair et al. (1995) não encontraram diferenças nas alterações dos arcos dentais provocadas pelas chupetas anatômica (NUK'M) e pela convencional, e concluíram que não há vantagem entre o uso de chupeta anatômica sobre a convencional. TurgeonO’Brien et al. (1996) afirmaram que há poucos dados científicos para apoiar a troca das chupetas convencionais pelas anatômicas, e que mais estudos são necessários nesta área.

Entretanto, parece-nos preferível indicar a chupeta anatômica, pois em alguns parâmetros avaliados, as crianças que utilizavam este tipo de chupeta apresentavam menores alterações que aquelas que sugavam a 
convencional; sendo interessante a realização de estudos posteriores quanto a interferência do uso da chupeta nas funções bucais. 


\section{CONCLUSÕES}

De acordo com os resultados obtidos, afirma-se que:

6.1 Quanto menor o tempo de aleitamento materno exclusivo maior a prevalência de uso da chupeta;

6.2 A presença de chupetas no enxoval da criança foi relacionado com uma maior freqüência de uso da chupeta;

6.3 Não houve associação significante entre o sexo da criança, renda familiar, número de irmãos e o fato de continuar usando a mamadeira com o uso ou não da chupeta;

6.4 Não houve associação estatisticamente significante entre a renda familiar e o grau de educação formal da mãe e o uso e tipo de chupeta;

6.5 Não foi encontrada relação estatisticamente significante entre o tipo de arco dental, relação terminal dos segundos molares decíduos, linha média e espaço primata entre e o uso e tipo de chupeta nos três grupos estudados; 
6.6 O uso da chupeta, tanto convencional quanto anatômica, favoreceram o desenvolvimento da mordida aberta anterior e cruzada posterior;

6.7 A relação canina Classe II foi mais prevalente no grupo de crianças que sugava chupeta do que no grupo que não tinham hábito de sucção de chupeta;

6.8 Não houve diferença significante entre as médias de mordida aberta anterior e sobremordida das crianças que sugavam chupeta convencional ou anatômica; porém, encontrou-se associação significante entre as crianças que nunca sugaram chupeta e as que tinham este hábito de sucção;

6.9 A distância intercanina do arco superior (ponta da cúspide) foi menor nas crianças que usavam chupeta convencional ou anatômica, quando comparada घ̀uuela existente nas crianças que não tinham este hábito. Não houve diferença estatisticamente significante entre os tipos de chupetas utilizados pelas crianças;

6.10 Não houve diferença estatisticamente significante entre as médias das distâncias intercaninas do arco inferior (ponta da cúspide e cervical) para nenhum dos grupos estudados; 
6.11 O modo como a criança sugava a chupeta apresentou correlação significante somente com a sobressaliência, sendo que a prevalência nas crianças que "sugavam sempre" foi estatisticamente maior do que naquelas que sugavam “as vezes ou "só apoiavam” a chupeta na boca;

6.12 Foi encontrado maior freqüência de palato duro normal entre as crianças que nunca sugaram chupeta ou que usavam chupeta anatômica, sendo significantemente maior do que no grupo que usou a chupeta convencional;

6.13 Foi observada que a probabilidade de mobilidade da bochecha normal foi significantemente maior entre as crianças que nunca usaram chupeta do que entre aquelas que usavam-na. 
ANEXOS

ANÁLISE ESTATÍSTICA 
ANEXO A

QUESTIONÁRIO

1. Tabelas descritivas univariadas das variáveis do questionário sobre hábito de sucção de chupeta (distribuições de freqüências das variáveis categorizadas)

TABELA A 1.1 - Distribuição dasfreqüências da variável "Sexo"

\begin{tabular}{ccc}
\hline Sexo & Freqüência absoluta & Freqüência relativa \\
\hline Feminino & 24 & $39,3 \%$ \\
\hline Masculino & 37 & $60,7 \%$ \\
\hline Total & 61 & $100,0 \%$ \\
\hline
\end{tabular}

TABELA A 1.2 - Distribuição de freqüências da variável "Irmãos"

\begin{tabular}{ccc}
\hline Irmãos & Freqüência absoluta & Freqüência relativa \\
\hline Filho único & 25 & $41,7 \%$ \\
\hline 1-2 irmãos & 33 & $55,0 \%$ \\
\hline 3 ou mais irmãos & 2 & $3,3 \%$ \\
\hline Total & 60 & $100,0 \%$ \\
\hline Obs.: Ocorreu 1 não-resposta & &
\end{tabular}

TABELA A 1.3 - Distribuição dasfreqüências da variável "Aleitamento materno"

\begin{tabular}{ccc} 
Amamentou no peito & Freqüência absoluta & Freqüência relativa \\
\hline Sim & 58 & $95,1 \%$ \\
\hline Não & 3 & $4,9 \%$ \\
\hline Total & 61 & $100,0 \%$ \\
\hline
\end{tabular}


TABELA A 1.4- Distribuição dasfreqüências da variável "Início do aleitamento materno exclusivo"

\begin{tabular}{lcc}
\hline Início da amamentação exclusiva & $\begin{array}{c}\text { Freqüência } \\
\text { absoluta }\end{array}$ & $\begin{array}{c}\text { Freqüência } \\
\text { relativa }\end{array}$ \\
\hline Nascimento & 56 & $98,2 \%$ \\
\hline Primeiro mês & 1 & $1,8 \%$ \\
\hline Total & 57 & $100,0 \%$ \\
\hline Obs.: Ocorreu 1 não-resposta & &
\end{tabular}

TABELA A 1.5 - Distribuição dasfreqüências da variável "Término do aleitamento materno exclusivo"

\begin{tabular}{lcc}
\hline \multicolumn{1}{c}{ Término da amamentação exclusiva } & $\begin{array}{c}\text { Freqüência } \\
\text { absoluta }\end{array}$ & $\begin{array}{c}\text { Freqüência } \\
\text { relativa }\end{array}$ \\
\hline Até o primeiro mês & 15 & $25,9 \%$ \\
\hline 2 a 3 meses & 15 & $25,9 \%$ \\
\hline 3 a 4 meses & 8 & $13,8 \%$ \\
\hline 5 a 6 meses & 15 & $25,9 \%$ \\
\hline mais que 6 meses & 5 & $8,6 \%$ \\
\hline Total & 58 & $100,0 \%$ \\
\hline
\end{tabular}

TABELA A 1.6 - Distribuição dasfreqüências da variável "Término do aleitamento materno"

\begin{tabular}{lcc}
\hline \multicolumn{1}{c}{ Término da amamentação no peito } & $\begin{array}{c}\text { Freqüência } \\
\text { absoluta }\end{array}$ & $\begin{array}{c}\text { Freqüência } \\
\text { relativa }\end{array}$ \\
\hline Até 1 mês & 8 & $14,0 \%$ \\
\hline 2 a 3 meses & 6 & $10,5 \%$ \\
\hline 4 a 6 meses & 13 & $22,8 \%$ \\
\hline 7 a 12 meses & 20 & $35,1 \%$ \\
\hline 13 a 18 meses & 3 & $5,3 \%$ \\
\hline Mais que 24 meses 24 meses & 5 & $8,8 \%$ \\
\hline Total & 2 & $3,5 \%$ \\
\hline Obs: $O c o r$ & 57 & $100,0 \%$ \\
\hline
\end{tabular}

Obs.: Ocorreu 1 não-resposta 
TABELA A 1.7- Distribuição dasfreqüências da variável "Usou mamadeira"

\begin{tabular}{lcc}
\hline Usou mamadeira & $\begin{array}{c}\text { Freqüência } \\
\text { absoluta }\end{array}$ & $\begin{array}{c}\text { Freqüência } \\
\text { relativa }\end{array}$ \\
\hline Sim & 59 & $96,7 \%$ \\
\hline Não & 2 & $3,3 \%$ \\
\hline Total & 61 & $100,0 \%$ \\
\hline
\end{tabular}

TABELA A 1.8- Distribuição dasfreqüências da variável "Início da mamadeira"

\begin{tabular}{lcc}
\hline Início da mamadeira & $\begin{array}{c}\text { Freqüência } \\
\text { absoluta }\end{array}$ & $\begin{array}{c}\text { Freqüência } \\
\text { relativa }\end{array}$ \\
\hline Primeiro mês & 15 & $25,9 \%$ \\
\hline 2 a 3 meses & 10 & $17,2 \%$ \\
\hline 4 meses & 8 & $13,8 \%$ \\
\hline 5 a 6 meses & 8 & $13,8 \%$ \\
\hline Mais que 6 meses & 17 & $29,3 \%$ \\
\hline Total & 58 & $100,0 \%$ \\
\hline bs.: Ocorreu 1 não-resposta & &
\end{tabular}

TABELA A 1.9 - Distribuição dasfreqüências da variável "Continua usando mamadeira"

\begin{tabular}{lcc}
\hline Continua usando mamadeira & $\begin{array}{c}\text { Freqüência } \\
\text { absoluta }\end{array}$ & $\begin{array}{c}\text { Freqüência } \\
\text { relativa }\end{array}$ \\
\hline Sim & 37 & $63,8 \%$ \\
\hline Não & 21 & $36,2 \%$ \\
\hline Total & 58 & $100,0 \%$ \\
\hline
\end{tabular}

Obs.: Ocorreu 1 não-resposta 
TABELA A 1.10 - Distribuição das freqüências da variável "Quem iniciou o hábito"

\begin{tabular}{lcc}
\hline Quem iniciou hábito chupeta & $\begin{array}{c}\text { Freqüência } \\
\text { absoluta }\end{array}$ & $\begin{array}{c}\text { Freqüência } \\
\text { relativa }\end{array}$ \\
\hline Mãe & 22 & $64,7 \%$ \\
\hline Pai e mãe & 4 & $11,8 \%$ \\
\hline Avós & 3 & $8,8 \%$ \\
\hline Outro & 5 & $14,7 \%$ \\
\hline Total & 34 & $100,0 \%$ \\
\hline
\end{tabular}

TABELA A 1.11 - Distribuição das freqüências da variável "Idade de início do uso de chupeta"

\begin{tabular}{lcc}
\hline \multicolumn{1}{c}{ Idade de início uso da chupeta } & $\begin{array}{c}\text { Freqüência } \\
\text { absoluta }\end{array}$ & $\begin{array}{c}\text { Freqüência } \\
\text { relativa }\end{array}$ \\
\hline 1 mês & 27 & $79,4 \%$ \\
\hline 2 meses & 2 & $5,9 \%$ \\
\hline 3 a 6 meses & 3 & $8,8 \%$ \\
\hline 7 a 12 meses & 1 & $2,9 \%$ \\
\hline 19 a 24 meses & 1 & $2,9 \%$ \\
\hline Total & 34 & $100,0 \%$ \\
\hline
\end{tabular}

TABELA A 1.12 - Distribuição das freqüências da variável "Relaciona uso com"

\begin{tabular}{lcc}
\hline \multicolumn{1}{c}{ Relaciona uso com } & $\begin{array}{c}\text { Freqüência } \\
\text { absoluta }\end{array}$ & $\begin{array}{c}\text { Freqüência } \\
\text { relativa }\end{array}$ \\
\hline Tensão & 4 & $12,1 \%$ \\
\hline Hora de dormir & 16 & $48,5 \%$ \\
\hline Outro & 1 & $3,0 \%$ \\
\hline Não relacionou & 5 & $15,2 \%$ \\
\hline Tensão, hora de dormir & 7 & $21,2 \%$ \\
\hline Total & 33 & $100,0 \%$ \\
\hline
\end{tabular}

Obs.: Ocorreu 1 não-resposta 
TABELA A 1.13 - Distribuição das freqüências da variável "Momento do dia que usa chupeta"

\begin{tabular}{lcc}
\hline Momento do dia que usa chupeta & $\begin{array}{c}\text { Freqüência } \\
\text { absoluta }\end{array}$ & $\begin{array}{c}\text { Freqüência } \\
\text { relativa }\end{array}$ \\
\hline Só para dormir & 17 & $51,5 \%$ \\
\hline Antes de dormir & 6 & $18,2 \%$ \\
\hline Dia inteiro & 7 & $21,2 \%$ \\
\hline Outro & 3 & $9,1 \%$ \\
\hline Total & 33 & $100,0 \%$ \\
\hline Obs.: Ocorreu 1 não-resposta & &
\end{tabular}

TABELA A 1.14 - Distribuição das freqüências da variável "Fica com mais de uma chupeta"

\begin{tabular}{lccc}
\hline Fica com mais de uma chupeta & $\begin{array}{c}\text { Freqüência } \\
\text { absoluta }\end{array}$ & $\begin{array}{c}\text { Freqüência } \\
\text { relativa }\end{array}$ \\
\hline Sim & 6 & $19,4 \%$ \\
\hline Não & 25 & $80,6 \%$ \\
\hline Total & 31 & $100,0 \%$ \\
\hline
\end{tabular}

Obs.: Ocorreram 3 não-respostas

Tabela A. 1.16 - Distribuição de freqüências da variável "Onde usa chupeta agora"

\begin{tabular}{ccc}
\hline $\begin{array}{c}\text { Onde usa chupeta } \\
\text { agora }\end{array}$ & $\begin{array}{c}\text { Freqüência } \\
\text { absoluta }\end{array}$ & $\begin{array}{c}\text { Freqüência } \\
\text { relativa }\end{array}$ \\
\hline Só em casa & 29 & $85,3 \%$ \\
\hline na creche / escola & 0 & $0,0 \%$ \\
\hline Ambos & 5 & $14,7 \%$ \\
\hline Total & 34 & $100,0 \%$ \\
\hline
\end{tabular}


TABELA A 1.16. Distribuição das freqüências da variável "Chupeta fica presa àroupa"

\begin{tabular}{lcc}
\hline Chupeta fica presa àroupa & $\begin{array}{c}\text { Freqüência } \\
\text { absoluta }\end{array}$ & $\begin{array}{c}\text { Freqüência } \\
\text { relativa }\end{array}$ \\
\hline Sim & 11 & $32,4 \%$ \\
\hline Não & 23 & $67,6 \%$ \\
\hline Total & 34 & $100,0 \%$ \\
\hline
\end{tabular}

TABELA A 1.17- Distribuição das freqüências da variável "Fez curso de gestante ou pré-natal"

\begin{tabular}{lcc}
\hline Fez curso de gestante ou pré-natal & $\begin{array}{c}\text { Freqüência } \\
\text { absoluta }\end{array}$ & $\begin{array}{c}\text { Freqüência } \\
\text { relativa }\end{array}$ \\
\hline Sim & 48 & $82,8 \%$ \\
\hline Não & 10 & $17,2 \%$ \\
\hline Total & 58 & $100,0 \%$ \\
\hline
\end{tabular}

Obs.: Ocorreram 3 não-respostas

TABELA A 1.18- Distribuição das freqüências da variável "Orientação quanto àchupeta no curso"

\begin{tabular}{lcc}
\hline \multicolumn{1}{c}{ Orientação quanto àchupeta no curso } & $\begin{array}{c}\text { Freqüência } \\
\text { absoluta }\end{array}$ & $\begin{array}{c}\text { Freqüência } \\
\text { relativa }\end{array}$ \\
\hline Sim & 15 & $31,3 \%$ \\
\hline Não & 29 & $60,4 \%$ \\
\hline Não se lembra & 4 & $8,3 \%$ \\
\hline Total & 48 & $100,0 \%$ \\
\hline
\end{tabular}


TABELA A 1.19- Distribuição das freqüências da variável "Orientação quanto àmamadeira"

\begin{tabular}{lcc}
\hline Orientação quanto àmamadeira & $\begin{array}{c}\text { Freqüência } \\
\text { absoluta }\end{array}$ & $\begin{array}{c}\text { Freqüência } \\
\text { relativa }\end{array}$ \\
\hline Sim & 24 & $39,3 \%$ \\
\hline Não & 29 & $47,5 \%$ \\
\hline Não se lembra & 8 & $13,1 \%$ \\
\hline Total & 61 & $100,0 \%$ \\
\hline
\end{tabular}

TABELA A 1.20 - Distribuição das freqüências da variável "Quantas chupetas no enxoval"

\begin{tabular}{lcc}
\hline Quantas chupetas enxoval & $\begin{array}{c}\text { Freqüência } \\
\text { absoluta }\end{array}$ & $\begin{array}{c}\text { Freqüência } \\
\text { relativa }\end{array}$ \\
\hline Nenhuma & 14 & $29,8 \%$ \\
\hline 1 ou 2 chupetas & 22 & $46,8 \%$ \\
\hline Mais que 2 chupetas & 11 & $23,4 \%$ \\
\hline Total & 47 & $100,0 \%$ \\
\hline
\end{tabular}

Obs.: Ocorreram 14 não-respostas

TABELA A 1.21 - Distribuição das freqüências da variável "Levou chupetas para a maternidade"

\begin{tabular}{lcc}
\hline Levou chupetas para maternidade & $\begin{array}{c}\text { Freqüência } \\
\text { absoluta }\end{array}$ & $\begin{array}{c}\text { Freqüência } \\
\text { relativa }\end{array}$ \\
\hline Sim & 8 & $14,0 \%$ \\
\hline Não & 49 & $86,0 \%$ \\
\hline Total & 57 & $100,0 \%$ \\
\hline
\end{tabular}

Obs.: Ocorreram 4 não-respostas 
TABELA A 1.22- Distribuição das freqüências da variável "Usou chupeta na maternidade"

\begin{tabular}{lcc}
\hline Usou chupeta na maternidade & $\begin{array}{c}\text { Freqüência } \\
\text { absoluta }\end{array}$ & $\begin{array}{c}\text { Freqüência } \\
\text { relativa }\end{array}$ \\
\hline Sim & 3 & $5,5 \%$ \\
\hline Não & 52 & $94,5 \%$ \\
\hline Total & 55 & $100,0 \%$ \\
\hline
\end{tabular}

Obs.: Ocorreram 6 não-respostas

2. Tabelas descritivas bivariadas das variáveis do questionário sobre hábitos de sucção de chupeta (tabelas de distribuições de freqüências cruzadas e Estatística descritiva de algumas variáveis do questionário).

Distribuições de freqüências da variável "Usa chupeta" segundo as variáveis "Sexo", "Renda", "Estudo da mãe", "Irmãos", "Término do aleitamento materno exclusivo", "Término do aleitamento materno", "Continua usando mamadeira", "Quantas chupetas no enxoval", "Orientação quanto àchupeta no curso", "Levou chupetas para a maternidade" e "Algum problema de saúde"

As freqüências absolutas estão inseridas entre parêntese nas tabelas a seguir.

TABELA A 2.1- Distribuição das freqüências da variável "Usa chupeta" segundo a variável "Sexo"

\begin{tabular}{|c|c|c|c|}
\hline \multirow[b]{2}{*}{ Sexo } & \multicolumn{2}{|c|}{ Usa chupeta } & \multirow[b]{2}{*}{ Total } \\
\hline & Sim & Não & \\
\hline Feminino & $\begin{array}{c}54,2 \% \\
(13) \\
\end{array}$ & $\begin{array}{c}45,8 \% \\
(11)\end{array}$ & $\begin{array}{c}100,0 \% \\
(n=24)\end{array}$ \\
\hline Masculino & $\begin{array}{c}56,8 \% \\
(21)\end{array}$ & $\begin{array}{c}43,2 \% \\
(16)\end{array}$ & $\begin{array}{c}100,0 \% \\
(n=37)\end{array}$ \\
\hline Total & $\begin{array}{c}55,7 \% \\
(34)\end{array}$ & $\begin{array}{c}44,3 \% \\
(27)\end{array}$ & $\begin{array}{c}100,0 \% \\
(n=61)\end{array}$ \\
\hline
\end{tabular}


TABELA A 2.2 - Distribuição das freqüências da variável "Usa chupeta" segundo a variável "Renda familiar"

\begin{tabular}{|c|c|c|c|}
\hline \multirow[b]{2}{*}{ Renda familiar } & \multicolumn{2}{|c|}{ Usa chupeta } & \multirow[b]{2}{*}{ Total } \\
\hline & Sim & Não & \\
\hline $1 \quad-3$ sal. & $\begin{array}{c}59,1 \% \\
(13)\end{array}$ & $\begin{array}{c}40,9 \% \\
(9)\end{array}$ & $\begin{array}{c}100,0 \% \\
(n=22)\end{array}$ \\
\hline $3 \quad-5$ sal. & $\begin{array}{c}53,3 \% \\
(8) \\
\end{array}$ & $\begin{array}{c}46,7 \% \\
(7)\end{array}$ & $\begin{array}{c}100,0 \% \\
(n=15)\end{array}$ \\
\hline $5 \quad-7$ sal. & $\begin{array}{c}50,0 \% \\
(3)\end{array}$ & $\begin{array}{c}50,0 \% \\
(3)\end{array}$ & $\begin{array}{c}100,0 \% \\
(n=6)\end{array}$ \\
\hline Mais que 7 sal. & $\begin{array}{c}53,3 \% \\
(8) \\
\end{array}$ & $\begin{array}{c}46,7 \% \\
(7)\end{array}$ & $\begin{array}{c}100,0 \% \\
(n=15)\end{array}$ \\
\hline Total & $\begin{array}{c}55,2 \% \\
(32)\end{array}$ & $\begin{array}{c}44,8 \% \\
(26)\end{array}$ & $\begin{array}{c}100,0 \% \\
(n=58)\end{array}$ \\
\hline
\end{tabular}

Obs.: Ocorreram 3 não-respostas

TABELA A 2.3 - Distribuição das freqüências da variável "Usa chupeta" segundo a variável "Estudo da mãe"

\begin{tabular}{|c|c|c|c|}
\hline \multirow[b]{2}{*}{ Estudo mãe } & \multicolumn{2}{|c|}{ Usa chupeta } & \multirow[b]{2}{*}{ Total } \\
\hline & Sim & Não & \\
\hline Não estudou & $\begin{array}{c}100,0 \% \\
(2) \\
\end{array}$ & $\begin{array}{c}0,0 \% \\
(0) \\
\end{array}$ & $\begin{array}{c}100,0 \% \\
(n=2) \\
\end{array}$ \\
\hline Primeiro grau & $\begin{array}{c}51,7 \% \\
(15)\end{array}$ & $\begin{array}{c}48,3 \% \\
(14)\end{array}$ & $\begin{array}{c}100,0 \% \\
(n=29)\end{array}$ \\
\hline Segundo grau & $\begin{array}{c}62,5 \% \\
(10) \\
\end{array}$ & $\begin{array}{c}37,5 \% \\
(6) \\
\end{array}$ & $\begin{array}{c}100,0 \% \\
(n=16)\end{array}$ \\
\hline Superior & $\begin{array}{c}60,0 \% \\
(6) \\
\end{array}$ & $\begin{array}{c}40,0 \% \\
(4) \\
\end{array}$ & $\begin{array}{c}100,0 \% \\
(n=10)\end{array}$ \\
\hline Pós graduação & $\begin{array}{c}0,0 \% \\
(0) \\
\end{array}$ & $\begin{array}{c}100,0 \% \\
(3)\end{array}$ & $\begin{array}{c}100,0 \% \\
(n=3)\end{array}$ \\
\hline Total & $\begin{array}{c}55,0 \% \\
(33) \\
\end{array}$ & $\begin{array}{c}45,0 \% \\
(27)\end{array}$ & $\begin{array}{c}100,0 \% \\
(n=60)\end{array}$ \\
\hline
\end{tabular}

Obs.: Ocorreu 1 não-resposta 
TABELA A 2.4 - Distribuição das freqüências da variável "Usa chupeta" segundo a variável "Irmãos"

\begin{tabular}{|c|c|c|c|}
\hline \multirow[b]{2}{*}{ Irmãos } & \multicolumn{2}{|c|}{ Usa chupeta } & \multirow[b]{2}{*}{ Total } \\
\hline & Sim & Não & \\
\hline Filho único & $\begin{array}{c}60,0 \% \\
(15)\end{array}$ & $\begin{array}{c}40,0 \% \\
(10)\end{array}$ & $\begin{array}{c}100,0 \% \\
(n=25)\end{array}$ \\
\hline 1-2 irmãos & $\begin{array}{c}54,5 \% \\
(18)\end{array}$ & $\begin{array}{c}45,5 \% \\
(15)\end{array}$ & $\begin{array}{c}100,0 \% \\
(n=33)\end{array}$ \\
\hline 3 ou mais irmãos & $\begin{array}{c}0,0 \% \\
(0)\end{array}$ & $\begin{array}{c}100,0 \% \\
(2)\end{array}$ & $\begin{array}{c}100,0 \% \\
(n=2)\end{array}$ \\
\hline Total & $\begin{array}{c}55,0 \% \\
\text { (33) }\end{array}$ & $\begin{array}{c}45,0 \% \\
(27)\end{array}$ & $\begin{array}{c}100,0 \% \\
(n=60)\end{array}$ \\
\hline
\end{tabular}

Obs.: Ocorreu 1 não-resposta

TABELA A 2.5 - Distribuição das freqüências da variável "Usa chupeta" segundo a variável "Orientação quanto àchupeta no curso"

\begin{tabular}{lccc}
\hline & \multicolumn{3}{c}{ Usa chupeta } \\
\cline { 2 - 3 } Orientação quanto àchupeta no curso & $\operatorname{sim}$ & Não & Total \\
\hline $\operatorname{Sim}$ & $53,3 \%$ & $46,7 \%$ & $100,0 \%$ \\
& $(8)$ & $(7)$ & $(\mathrm{n}=15)$ \\
\hline Não & $62,1 \%$ & $37,9 \%$ & $100,0 \%$ \\
& $(18)$ & $(11)$ & $(\mathrm{n}=29)$ \\
\hline Não se lembra & $50,0 \%$ & $50,0 \%$ & $100,0 \%$ \\
& $(2)$ & $(2)$ & $(\mathrm{n}=4)$ \\
\hline Total & $58,3 \%$ & $41,7 \%$ & $100,0 \%$ \\
& $(28)$ & $(20)$ & $(\mathrm{n}=48)$ \\
\hline
\end{tabular}

Obs.: Ocorreram 13 não-respostas 
TABELA A 2.6 - Distribuição das freqüências da variável "Usa chupeta" segundo a variável "Levou chupetas para a maternidade"

\begin{tabular}{|c|c|c|c|}
\hline \multirow[b]{2}{*}{ Levou chupetas para maternidade } & \multicolumn{2}{|c|}{ Usa chupeta } & \multirow[b]{2}{*}{ Total } \\
\hline & Sim & Não & \\
\hline Sim & $\begin{array}{c}37,5 \% \\
\text { (3) }\end{array}$ & $\begin{array}{c}62,5 \% \\
(5)\end{array}$ & $\begin{array}{c}100,0 \% \\
(n=8)\end{array}$ \\
\hline Não & $\begin{array}{c}61,2 \% \\
(30) \\
\end{array}$ & $\begin{array}{c}38,8 \% \\
(19) \\
\end{array}$ & $\begin{array}{r}100,0 \% \\
(n=49)\end{array}$ \\
\hline Total & $\begin{array}{c}57,9 \% \\
(33)\end{array}$ & $\begin{array}{c}42,1 \% \\
(24) \\
\end{array}$ & $\begin{array}{c}100,0 \% \\
(n=57)\end{array}$ \\
\hline
\end{tabular}

Obs.: Ocorreram 4 não-respostas

ii. Distribuições de freqüências das variáveis "Renda familiar", "Uso e tipo de chupeta", "Término do aleitamento materno exclusivo", "Formato do bico da mamadeira", e Estatística descritiva de "Tempo que usou mamadeira" segundo a variável "Estudo da mãe"

TABELA A 2.7- Distribuição das freqüências da variável "Término do aleitamento materno exclusivo" segundo a variável "Estudo da mãe"

\begin{tabular}{lcccccc}
\hline & \multicolumn{7}{c}{ Término da amamentação exclusiva } & \\
\cline { 2 - 6 } & Até o & & & & & \\
Estudo mãe & primeiro & 2 a 3 & 3 a 4 & 5 a 6 & mais que & \\
\hline Não estudou & mês & meses & meses & meses & 6 meses & Total \\
& $50,0 \%$ & $50,0 \%$ & $0,0 \%$ & $0,0 \%$ & $0,0 \%$ & $100,0 \%$ \\
& $(1)$ & $(1)$ & $(0)$ & $(0)$ & $(0)$ & $(\mathrm{n}=2)$ \\
\hline Primeiro grau & $33,3 \%$ & $25,9 \%$ & $11,1 \%$ & $22,2 \%$ & $7,4 \%$ & $100,0 \%$ \\
& $(9)$ & $(7)$ & $(3)$ & $6)$ & $(2)$ & $(\mathrm{n}=27)$ \\
\hline Segundo grau & $13,3 \%$ & $33,3 \%$ & $20,0 \%$ & $20,0 \%$ & $13,3 \%$ & $100,0 \%$ \\
& $(2)$ & $(5)$ & $(3)$ & $(3)$ & $(2)$ & $(\mathrm{n}=15)$ \\
\hline Superior & $30,0 \%$ & $0,0 \%$ & $20,0 \%$ & $40,0 \%$ & $10,0 \%$ & $100,0 \%$ \\
& $(3)$ & $(0)$ & $(2)$ & $(4)$ & $(1)$ & $(\mathrm{n}=10)$ \\
\hline Pós graduação & $0,0 \%$ & $66,7 \%$ & $0,0 \%$ & $33,3 \%$ & $0,0 \%$ & $100,0 \%$ \\
& $(0)$ & $(2)$ & $(0)$ & $(1)$ & $(0)$ & $(\mathrm{n}=3)$ \\
\hline Total & $26,3 \%$ & $26,3 \%$ & $14,0 \%$ & $24,6 \%$ & $8,8 \%$ & $100,0 \%$ \\
& $(15)$ & $(15)$ & $(8)$ & $(14)$ & $(5)$ & $(\mathrm{n}=57)$ \\
\hline
\end{tabular}


TABELA A 2.8- Estatística descritiva da variável "Tempo que uso mamadeira" segundo a variável "Estudo da mãe"

\begin{tabular}{lcccccc}
\hline Estudo mãe & $\mathrm{N}$ & Média & $\begin{array}{c}\text { Desvio } \\
\text { Padrão }\end{array}$ & Mínimo & Máximo & Mediana \\
\hline Não estudou & 2 & 43,0 & 12,73 & 34,0 & 52,0 & 43,0 \\
\hline Primeiro grau & 26 & 35,5 & 14,46 & 7,0 & 67,0 & 38,5 \\
\hline Segundo grau & 16 & 34,8 & 13,81 & 8,0 & 55,0 & 38,0 \\
\hline Superior & 10 & 37,0 & 9,36 & 18,0 & 52,0 & 36,5 \\
\hline $\begin{array}{l}\text { Pós } \\
\text { graduação }\end{array}$ & 3 & 17,3 & 13,58 & 9,0 & 33,0 & 10,0 \\
\hline Obs.: Ocorreram 2 não-respostas & & & & & &
\end{tabular}

iii. Distribuições de freqüências das variáveis "Uso e tipo de chupeta", "Término do aleitamento materno exclusivo", "Formato do bico da mamadeira", e estatísticas descritivas de "Tempo que usou mamadeira" segundo a variável "Renda familiar"

TABELA A 2.9- Distribuição das freqüências da variável "Uso e tipo de chupeta" segundo a variável "Renda Familiar"

\begin{tabular}{lcccc}
\hline & \multicolumn{3}{c}{ Uso e tipo de chupeta } & \\
\cline { 2 - 4 } Renda familiar & \multicolumn{3}{c}{ Usa } & Total \\
\hline 1-3 sal. & Nunca usou & ortodôntica & Usa comum & Tom \\
& $40,9 \%$ & $31,8 \%$ & $27,3 \%$ & $100,0 \%$ \\
\hline 3-5 sal. & $(9)$ & $(7)$ & $(6)$ & $(\mathrm{n}=22)$ \\
\hline 5-7 sal. & $46,7 \%$ & $33,3 \%$ & $20,0 \%$ & $100,0 \%$ \\
& $(7)$ & $(5)$ & $(3)$ & $(\mathrm{n}=15)$ \\
\hline Mais que 7 sal. & $50,0 \%$ & $16,7 \%$ & $33,3 \%$ & $100,0 \%$ \\
& $(3)$ & $(1)$ & $(2)$ & $(\mathrm{n}=6)$ \\
\hline Total & $46,7 \%$ & $33,3 \%$ & $20,0 \%$ & $100,0 \%$ \\
& $(7)$ & $(5)$ & $(3)$ & $(\mathrm{n}=15)$ \\
\hline
\end{tabular}

Obs.: Ocorreram 3 não-respostas 
TABELA A 2.10 - Distribuição das freqüências da variável "Término da amamentação exclusiva" segundo a variável "Renda familiar"

\begin{tabular}{lcccccc}
\hline & \multicolumn{7}{c}{ Amamentação exclusiva final } & \\
\cline { 2 - 6 } & $\begin{array}{c}\text { Até o } \\
\text { primeiro }\end{array}$ & 2 a 3 & 3 a 4 & 5 a 6 & mais que & \\
Renda familiar & mês & meses & meses & meses & 6 meses & Total \\
\hline 1-3 sal. & $25,0 \%$ & $35,0 \%$ & $10,0 \%$ & $20,0 \%$ & $10,0 \%$ & $100,0 \%$ \\
& $(5)$ & $(7)$ & $(2)$ & $(4)$ & $(2)$ & $(\mathrm{n}=20)$ \\
\hline 3-5 sal. & $21,4 \%$ & $28,6 \%$ & $21,4 \%$ & $14,3 \%$ & $14,3 \%$ & $100,0 \%$ \\
& $(3)$ & $(4)$ & $(3)$ & $(2)$ & $(2)$ & $(\mathrm{n}=14)$ \\
\hline 5-7 sal. & $16,7 \%$ & $16,7 \%$ & $0,0 \%$ & $50,0 \%$ & $16,7 \%$ & $100,0 \%$ \\
& $(1)$ & $(1)$ & $(0)$ & $(3)$ & $(1)$ & $(\mathrm{n}=6)$ \\
\hline Mais que 7 sal. & $33,3 \%$ & $13,3 \%$ & $20,0 \%$ & $33,3 \%$ & $0,0 \%$ & $100,0 \%$ \\
& $(5)$ & $(2)$ & $(3)$ & $(5)$ & $(0)$ & $(\mathrm{n}=15)$ \\
\hline Total & $25,5 \%$ & $25,5 \%$ & $14,5 \%$ & $25,5 \%$ & $9,1 \%$ & $100,0 \%$ \\
& $(14)$ & $(14)$ & $(8)$ & $(14)$ & $(5)$ & $(\mathrm{n}=55)$ \\
\hline
\end{tabular}

Obs.: Ocorreram 3 não-respostas

TABELA A 2.11 - Estatística descritiva da variável "Tempo que uso mamadeira" segundo a variável "Renda familiar"

\begin{tabular}{lcccccc}
\hline Renda familiar & $\mathrm{N}$ & Média & $\begin{array}{c}\text { Desvio } \\
\text { Padrão }\end{array}$ & Mínimo & Máximo & Mediana \\
\hline 1-3 sal. & 19 & 35,3 & 16,38 & 7,0 & 67,0 & 37,0 \\
\hline 3-5 sal. & 15 & 32,4 & 11,87 & 15,0 & 53,0 & 30,0 \\
\hline 5-7 sal. & 6 & 43,3 & 6,56 & 37,0 & 52,0 & 41,0 \\
\hline mais que 7 sal. & 15 & 30,7 & 11,48 & 9,0 & 49,0 & 34,0 \\
\hline
\end{tabular}

Obs.: Ocorreram 4 não-respostas 
TABELA A 2.12.- Distribuição das freqüências da variável "Momento do dia que usa chupeta" segundo a variável "Uso e tipo de chupeta"

\begin{tabular}{lccccc}
\hline & \multicolumn{4}{c}{ Momento do dia que usa chupeta } & \multicolumn{1}{c}{} \\
\cline { 2 - 5 } & Só para & Antes de & Dia & & \\
Uso e tipo de chupeta & dormir & dormir & inteiro & Outro & Total \\
\hline Usa ortodôntica & $52,6 \%$ & $15,8 \%$ & $21,1 \%$ & $10,5 \%$ & $100,0 \%$ \\
& $(10)$ & $(3)$ & $(4)$ & $(2)$ & $(\mathrm{n}=19)$ \\
\hline Usa comum & $50,0 \%$ & $21,4 \%$ & $21,4 \%$ & $7,1 \%$ & $100,0 \%$ \\
& $(7)$ & $(3)$ & $(3)$ & $(1)$ & $(\mathrm{n}=14)$ \\
\hline Total & $51,5 \%$ & $18,2 \%$ & $21,2 \%$ & $9,1 \%$ & $100,0 \%$ \\
& $(17)$ & $(6)$ & $(7)$ & $(3)$ & $(\mathrm{n}=33)$ \\
\hline
\end{tabular}

Obs.: Ocorreu 1 não-resposta

TABELA A 2.13.- Distribuição das freqüências da variável "Como suga" segundo a variável "Uso e tipo de chupeta"

\begin{tabular}{lcccc}
\hline & \multicolumn{3}{c}{ Como suga } & \\
\cline { 2 - 4 } & Suga & Suga às & \\
Uso e tipo de chupeta & sempre & vezes & Apoia & Total \\
\hline Usa ortodôntica & $42,1 \%$ & $47,4 \%$ & $10,5 \%$ & $100,0 \%$ \\
& $(8)$ & $(9)$ & $(2)$ & $(\mathrm{n}=19)$ \\
\hline Usa comum & $35,7 \%$ & $57,1 \%$ & $7,1 \%$ & $100,0 \%$ \\
& $(5)$ & $(8)$ & $(1)$ & $(\mathrm{n}=14)$ \\
\hline Total & $39,4 \%$ & $51,5 \%$ & $9,1 \%$ & $100,0 \%$ \\
& $(13)$ & $(17)$ & $(3)$ & $(\mathrm{n}=33)$ \\
\hline
\end{tabular}

Obs.: Ocorreu 1 não-resposta

3. Tabelas da análise inferencial das variáveis do questionário sobre hábitos de sucção de chupeta Testes de Independência e análises de variância relativos às tabelas cruzadas da seção anterior). 
TABELA A 3.1 - Testes de Independência (Qiu-quadrado de Pearson) entre as variáveis "Renda familiar", "Uso e tipo de chupeta", "Término da amamentação exclusiva" e "Formato do bico da mamadeira" e a variável "Estudo da mãe"

\begin{tabular}{lcc}
\hline Variável do questionário & $\begin{array}{c}\text { Valor da estatística Qui- } \\
\text { quadrado de Pearson }\end{array}$ & \begin{tabular}{c} 
exato $(\mathrm{p})$ \\
\hline Renda familiar
\end{tabular} \\
\hline Uso e tipo de chupeta & 46,981 & 0,000 \\
\hline Término da amamentação exclusiva & 11,892 & 0,146 \\
\hline Formato do bico da mamadeira & 12,041 & 0,791 \\
\hline
\end{tabular}

TABELA A 3.2 - Análise de variância para a variável "Tempo que usou mamadeira" (fator "Escolaridade da mãe")

\begin{tabular}{lccccc}
\hline Fonte de variação & $\begin{array}{c}\text { graus de } \\
\text { liberdade }\end{array}$ & $\begin{array}{c}\text { Soma de } \\
\text { quadrados }\end{array}$ & $\begin{array}{c}\text { Quadrado } \\
\text { Médio }\end{array}$ & \multicolumn{2}{c}{$\begin{array}{c}\text { Nível } \\
\text { descritivo } \\
(\mathrm{p})\end{array}$} \\
\hline Escolaridade da mãe & 4 & 1112,012 & 278,003 & 1,537 & 0,205 \\
\hline Resíduo & 52 & 9406,128 & 180,887 & & \\
\hline Total & 56 & 10518,140 & & & \\
\hline
\end{tabular}

TABELA A 3.3 - Testes de independência entre as variáveis "Uso e tipo de chupeta", "Término da amamentação exclusiva" e "Formato do bico da mamadeira" e a variável "Renda familiar"

\begin{tabular}{lcc}
\hline \multicolumn{1}{c}{ Variável do questionário } & $\begin{array}{c}\text { Valor da estatística Qui- } \\
\text { quadrado de Pearson }\end{array}$ & $\begin{array}{c}\text { Nível descritivo } \\
\text { exato }(p)\end{array}$ \\
\hline Uso e tipo de chupeta & 1,101 & 0,984 \\
\hline Término da amamentação exclusiva & 9,257 & 0,722 \\
\hline Formato do bico da mamadeira & 12,758 & 0,033 * \\
\hline Or.
\end{tabular}

Obs.: A variável assinalada com um asterisco apresenta dependência significante com a variável "Renda familiar" ao nível de significância de 5\% 
TABELA A 3.4 - Análise de variância para a variável "Tempo que usou mamadeira" (fator "Renda familiar")

\begin{tabular}{lccccc}
\hline Fonte de variação & $\begin{array}{c}\text { Soma de } \\
\text { quadrados }\end{array}$ & $\begin{array}{c}\text { Graus de } \\
\text { liberdade }\end{array}$ & $\begin{array}{c}\text { Quadrado } \\
\text { Médio }\end{array}$ & $\begin{array}{c}\text { Nível } \\
\text { descritivo } \\
(\mathrm{p})\end{array}$ \\
\hline Renda familiar & 750,558 & 3,000 & 250,186 & 1,440 & 0,242 \\
\hline Resíduo & 8861,551 & 51,000 & 173,756 & & \\
\hline Total & 9612,109 & 54,000 & & & \\
\hline
\end{tabular}


ANEXO B

AVALIAÇÃO DOS ARCOS DENTAIS

1. Tabelas descritivas das variáveis da avaliação dos arcos dentais segundo a variável "Uso e tipo de chupeta" (distribuições percentuais das variáveis categorizadas e estatísticas descritivas das variáveis quantitativas das avaliação dos arcos dentais segundo a variável "Uso e tipo de chupeta").

TABELA B 1.1 - Distribuição das freqüências da variável "Tipo de arco superior" segundo a variável "Uso e tipo de chupeta"

\begin{tabular}{lccc}
\hline \multirow{2}{*}{ Uso e tipo de chupeta } & \multicolumn{2}{c}{ Tipo arco superior } & \multirow{2}{*}{ Total } \\
\cline { 2 - 3 } & Arco do tipo I & Arco do tipo II & Aro \\
\hline Nunca usou & $66,7 \%$ & $33,3 \%$ & $100,0 \%$ \\
& $(18)$ & $(9)$ & $(\mathrm{n}=27)$ \\
\hline Usa ortodôntica & $85,0 \%$ & $15,0 \%$ & $100,0 \%$ \\
& $(17)$ & $(3)$ & $(\mathrm{n}=20)$ \\
\hline Usa comum & $85,7 \%$ & $14,3 \%$ & $100,0 \%$ \\
& $(12)$ & $(2)$ & $(\mathrm{n}=14)$ \\
\hline Total & $77,0 \%$ & $23,0 \%$ & $100,0 \%$ \\
& $(47)$ & $(14)$ & $(\mathrm{n}=61)$ \\
\hline
\end{tabular}

TABELA B 1.2 - Distribuição das freqüências da variável "Tipo de arco inferior" segundo a variável "Uso e tipo de chupeta"

\begin{tabular}{lccc}
\hline \multirow{2}{*}{ Uso e tipo de chupeta } & \multicolumn{2}{c}{ Tipo arco inferior } & \\
\cline { 2 - 3 } & Arco do tipo I & Arco do tipo II & Total \\
\hline Nunca usou & $55,6 \%$ & $44,4 \%$ & $100,0 \%$ \\
& $(15)$ & $(12)$ & $(\mathrm{n}=27)$ \\
\hline Usa ortodôntica & $80,0 \%$ & $20,0 \%$ & $100,0 \%$ \\
& $(16)$ & $(4)$ & $(\mathrm{n}=20)$ \\
\hline Usa comum & $85,7 \%$ & $14,3 \%$ & $100,0 \%$ \\
& $(12)$ & $(2)$ & $(\mathrm{n}=14)$ \\
\hline Total & $70,5 \%$ & $29,5 \%$ & $100,0 \%$ \\
& $(43)$ & $(18)$ & $(\mathrm{n}=61)$ \\
\hline
\end{tabular}


TABELA B 1.3 - Distribuição das freqüências da variável "Desvio de linha média" segundo a variável "Uso e tipo de chupeta"

\begin{tabular}{lcccc}
\hline \multirow{2}{*}{$\begin{array}{l}\text { Uso e tipo de } \\
\text { chupeta }\end{array}$} & \multicolumn{4}{c}{ Desvio de linha média } \\
\cline { 2 - 4 } Nunca usou & Não & Lado direito esquerdo & Total \\
\hline Usa ortodôntica & $77,8 \%$ & $14,8 \%$ & $7,4 \%$ & $100,0 \%$ \\
& $(21)$ & $(4)$ & $(2)$ & $(\mathrm{n}=27)$ \\
\hline Usa comum & $(11)$ & $25,0 \%$ & $20,0 \%$ & $100,0 \%$ \\
& $92,9 \%$ & $(5)$ & $(4)$ & $(\mathrm{n}=20)$ \\
\hline Total & $(13)$ & $(0)$ & $7,1 \%$ & $100,0 \%$ \\
& $73,8 \%$ & $14,8 \%$ & $11,5 \%$ & $(\mathrm{n}=14)$ \\
\hline & $(45)$ & $(9)$ & $(7)$ & $100,0 \%$ \\
& & & & $(\mathrm{n}=61)$ \\
\hline
\end{tabular}

TABELA B 1.4 - Distribuição das freqüências da variável "Espaço primata superior" segundo a variável "Uso e tipo de chupeta"

\begin{tabular}{lccc}
\hline \multirow{2}{*}{ Uso e tipo de chupeta } & \multicolumn{2}{c}{ Espaço primata superior } & Total \\
\cline { 2 - 3 } & Sim & Não & $100,0 \%$ \\
Nunca usou & $92,6 \%$ & $7,4 \%$ & $(\mathrm{n}=27)$ \\
\hline Usa ortodôntica & $(25)$ & $(2)$ & $100,0 \%$ \\
& $95,0 \%$ & $5,0 \%$ & $(\mathrm{n}=20)$ \\
\hline Usa comum & $(19)$ & $(1)$ & $100,0 \%$ \\
& $100,0 \%$ & $0,0 \%$ & $(\mathrm{n}=14)$ \\
\hline Total & $(14)$ & $(0)$ & $100,0 \%$ \\
& $95,1 \%$ & $4,9 \%$ & $(\mathrm{n}=61)$ \\
\hline
\end{tabular}

TABELA B 1.5 - Distribuição das freqüências da variável "Espaço primata inferior" segundo a variável "Uso e tipo de chupeta"

\begin{tabular}{lccc}
\hline \multirow{2}{*}{ Uso e tipo de chupeta } & \multicolumn{2}{c}{ Espaço primata inferior } & Total \\
\cline { 2 - 3 } Nunca usou & Sim & Não & $100,0 \%$ \\
& $88,9 \%$ & $11,1 \%$ & $(\mathrm{n}=27)$ \\
\hline Usa ortodôntica & $(24)$ & $(3)$ & $100,0 \%$ \\
& $75,0 \%$ & $25,0 \%$ & $(\mathrm{n}=20)$ \\
\hline Usa comum & $(15)$ & $(5)$ & $100,0 \%$ \\
& $92,9 \%$ & $7,1 \%$ & $(\mathrm{n}=14)$ \\
\hline Total & $(13)$ & $(1)$ & $100,0 \%$ \\
& $85,2 \%$ & $14,8 \%$ & $(\mathrm{n}=61)$ \\
\hline
\end{tabular}


TABELA B 1.6 - Distribuição das freqüências da variável "Relação molar lado direito" segundo a variável "Uso e tipo de chupeta"

\begin{tabular}{lcccc}
\hline & \multicolumn{3}{c}{ Relação molar lado direito } & \\
\cline { 2 - 5 } \multicolumn{1}{c}{ Use elação } & Relação & Plano & \multirow{2}{*}{ Total } \\
\hline Nunca usou & distal & mesial & reto & $100,0 \%$ \\
& $11,1 \%$ & $59,3 \%$ & $29,6 \%$ & $(\mathrm{n}=27)$ \\
\hline Usa ortodôntica & $(3)$ & $(16)$ & $8)$ & $100,0 \%$ \\
& $10,0 \%$ & $55,0 \%$ & $35,0 \%$ & $(\mathrm{n}=20)$ \\
\hline Usa comum & $(2)$ & $(11)$ & $(7)$ & $100,0 \%$ \\
& $14,3 \%$ & $28,6 \%$ & $57,1 \%$ & $(\mathrm{n}=14)$ \\
\hline Total & $(2)$ & $(4)$ & $(8)$ & $100,0 \%$ \\
& $11,5 \%$ & $50,8 \%$ & $37,7 \%$ & $(\mathrm{n}=61)$ \\
\hline
\end{tabular}

TABELA B 1.7 - Distribuição das freqüências da variável "Relação molar lado esquerdo" segundo a variável "Uso e tipo de chupeta"

\begin{tabular}{lcccc}
\hline & \multicolumn{3}{c}{ Relação molar lado esquerdo } & \\
\cline { 2 - 4 } & Relação & Relação & Plano & \\
Uso e tipo de chupeta & distal & mesial & reto & Total \\
\hline Nunca usou & $7,4 \%$ & $59,3 \%$ & $33,3 \%$ & $100,0 \%$ \\
& $(2)$ & $(16)$ & $9)$ & $(n=27)$ \\
\hline Usa ortodôntica & $15,0 \%$ & $50,0 \%$ & $35,0 \%$ & $100,0 \%$ \\
& $(3)$ & $(10)$ & $(7)$ & $(n=20)$ \\
\hline Usa comum & $14,3 \%$ & $35,7 \%$ & $50,0 \%$ & $100,0 \%$ \\
& $(2)$ & $(5)$ & $(7)$ & $(n=14)$ \\
\hline Total & $11,5 \%$ & $50,8 \%$ & $37,7 \%$ & $100,0 \%$ \\
& $(7)$ & $(31)$ & $(23)$ & $(n=61)$ \\
\hline
\end{tabular}

TABELA B 1.8 - Distribuição das freqüências da variável "Mordida aberta posterior" segundo a variável "Uso e tipo de chupeta"

\begin{tabular}{lccc}
\hline \multirow{2}{*}{ Uso e tipo de chupeta } & \multicolumn{2}{c}{ Mordida aberta posterior } & Total \\
\cline { 2 - 3 } & Sim & Não & \\
\hline Nunca usou & $0,0 \%$ & $100,0 \%$ & $100,0 \%$ \\
& $(0)$ & $(27)$ & $(n=27)$ \\
\hline Usa ortodôntica & $0,0 \%$ & $100,0 \%$ & $100,0 \%$ \\
& $(0)$ & $(20)$ & $(n=20)$ \\
\hline Usa comum & $0,0 \%$ & $100,0 \%$ & $100,0 \%$ \\
& $(0)$ & $(14)$ & $(n=14)$ \\
\hline Total & $0,0 \%$ & $100,0 \%$ & $100,0 \%$ \\
& $(0)$ & $(61)$ & $(n=61)$ \\
\hline
\end{tabular}


TABELA B 1.9 - Distribuição das freqüências da variável "Relação canina lado direito" segundo a variável "Uso e tipo de chupeta"

\begin{tabular}{|c|c|c|c|c|}
\hline \multirow[b]{2}{*}{ Uso e tipo de chupeta } & \multicolumn{3}{|c|}{ Relação canina lado direito } & \multirow[b]{2}{*}{ Total } \\
\hline & $\begin{array}{l}\text { Relação } \\
\text { Classe I }\end{array}$ & $\begin{array}{l}\text { Relação } \\
\text { Classe II }\end{array}$ & $\begin{array}{l}\text { Relação } \\
\text { Classe III }\end{array}$ & \\
\hline Nunca usou & $\begin{array}{c}81,5 \% \\
(22) \\
\end{array}$ & $\begin{array}{c}11,1 \% \\
(3)\end{array}$ & $\begin{array}{c}7,4 \% \\
(2) \\
\end{array}$ & $\begin{array}{c}100,0 \% \\
(n=27)\end{array}$ \\
\hline Usa ortodôntica & $\begin{array}{c}40,0 \% \\
(8) \\
\end{array}$ & $\begin{array}{c}60,0 \% \\
(12) \\
\end{array}$ & $\begin{array}{c}0,0 \% \\
(0)\end{array}$ & $\begin{array}{c}100,0 \% \\
(n=20)\end{array}$ \\
\hline Usa comum & $\begin{array}{c}28,6 \% \\
(4) \\
\end{array}$ & $\begin{array}{c}71,4 \% \\
(10) \\
\end{array}$ & $\begin{array}{c}0,0 \% \\
(0)\end{array}$ & $\begin{array}{c}100,0 \% \\
(n=14)\end{array}$ \\
\hline Total & $\begin{array}{c}55,7 \% \\
(34)\end{array}$ & $\begin{array}{c}41,0 \% \\
(25)\end{array}$ & $\begin{array}{c}3,3 \% \\
(2)\end{array}$ & $\begin{array}{c}100,0 \% \\
(n=61)\end{array}$ \\
\hline
\end{tabular}

TABELA B 1.10 - Distribuição das freqüências da variável "Relação canina lado esquerdo" segundo a variável "Uso e tipo de chupeta"

\begin{tabular}{lcccc}
\hline & \multicolumn{3}{c}{ Relação canina lado esquerdo } & \\
\cline { 2 - 4 } \multicolumn{1}{c}{ Uelação } & Relação & Relação & \\
\hline Nunca usou & Classe I & Classe II & Classe III & Total \\
\hline Usa ortodôntica & $85,2 \%$ & $11,1 \%$ & $3,7 \%$ & $100,0 \%$ \\
& $(23)$ & $(3)$ & $(1)$ & $(\mathrm{n}=27)$ \\
\hline Usa comum & $60,0 \%$ & $40,0 \%$ & $0,0 \%$ & $100,0 \%$ \\
& $(12)$ & $(8)$ & $(0)$ & $(\mathrm{n}=20)$ \\
\hline Total & $42,9 \%$ & $57,1 \%$ & $0,0 \%$ & $100,0 \%$ \\
& $(6)$ & $(8)$ & $(0)$ & $(\mathrm{n}=14)$ \\
\hline & $67,2 \%$ & $31,1 \%$ & $1,6 \%$ & $100,0 \%$ \\
& $(41)$ & $(19)$ & $(1)$ & $(\mathrm{n}=61)$ \\
\hline
\end{tabular}


TABELA B 1.11 - Distribuição das freqüências da variável "Sobremordida" segundo a variável "Uso e tipo de chupeta"

\begin{tabular}{|c|c|c|c|c|c|c|}
\hline \multirow[b]{2}{*}{$\begin{array}{l}\text { Uso e tipo } \\
\text { de chupeta }\end{array}$} & \multicolumn{5}{|c|}{ Sobremordida } & \multirow[b]{2}{*}{ Total } \\
\hline & $\begin{array}{c}50 \% \text { ou } \\
\text { menos }\end{array}$ & $\begin{array}{c}\text { mais } \\
\text { que } 50 \%\end{array}$ & $\begin{array}{c}\text { Topo a } \\
\text { topo }\end{array}$ & $\begin{array}{c}\text { Mordida } \\
\text { aberta }\end{array}$ & $\begin{array}{l}\text { Cruzada } \\
\text { anterior }\end{array}$ & \\
\hline Nunca usou & & & & & & $100,0 \%$ \\
\hline & $63,0 \%$ & $29,6 \%$ & $3,7 \%$ & $0,0 \%$ & $3,7 \%$ & $(\mathrm{n}=27)$ \\
\hline $\begin{array}{l}\text { Usa } \\
\text { ortodôntica }\end{array}$ & $20,0 \%$ & $20,0 \%$ & $10,0 \%$ & $50,0 \%$ & $0,0 \%$ & $\begin{array}{r}100,0 \% \\
(\mathrm{n}=20) \\
\end{array}$ \\
\hline Usa comum & $35,7 \%$ & $7,1 \%$ & $7,1 \%$ & $50,0 \%$ & $0,0 \%$ & $\begin{array}{r}100,0 \% \\
(n=14) \\
\end{array}$ \\
\hline Total & $42,6 \%$ & $21,3 \%$ & $6,6 \%$ & $27,9 \%$ & $1,6 \%$ & $\begin{array}{r}100,0 \% \\
(\mathrm{n}=61) \\
\end{array}$ \\
\hline
\end{tabular}

TABELA B 1.12 - Estatística descritiva da variável "Distância intercanina do arco inferior- Ponta da cúspide ( $\mathrm{mm})$ " segundo a variável "Uso e tipo de chupeta"

\begin{tabular}{lcccccc}
\hline & $\mathrm{n}$ & Média & $\begin{array}{c}\text { Desvio } \\
\text { Padrão }\end{array}$ & Mínimo & Máximo & Mediana \\
\hline Nunca usou & 27 & 25,2 & 1,76 & 22,0 & 29,0 & 25,0 \\
\hline Usa ortodôntica & 20 & 25,6 & 1,62 & 22,0 & 28,0 & 26,0 \\
\hline Usa comum & 14 & 25,2 & 1,09 & 23,0 & 26,5 & 25,3 \\
\hline
\end{tabular}

TABELA B 1.13 - Estatística descritiva da variável "Distância intercanina do arco inferior- Cervical (mm)" segundo a variável "Uso e tipo de chupeta"

\begin{tabular}{lcccccc}
\hline & $\mathrm{n}$ & Média & $\begin{array}{c}\text { Desvio } \\
\text { Padrão }\end{array}$ & Mínimo & Máximo & Mediana \\
\hline Nunca usou & 27 & 20,4 & 1,69 & 18,0 & 24,0 & 20,5 \\
\hline Usa ortodôntica & 20 & 20,8 & 1,44 & 19,0 & 24,0 & 20,5 \\
\hline Usa comum & 14 & 20,5 & 1,99 & 19,0 & 26,0 & 20,0 \\
\hline
\end{tabular}




\section{Análises de Variância das variáveis quantitativas da avaliação dos arcos dentais com o fator "Uso e tipo de chupeta").}

TABELA B 2.1 - Análise de variância para a variável "Distância intercanina do arco superior - Ponta da cúspide (mm)"

\begin{tabular}{lccccc}
\hline & & \multicolumn{2}{c}{ Graus de } & & \multicolumn{2}{c}{ Nível } \\
Fonte de variação & Somadrado & de quadrados & descritivo \\
liberdade & Médio & $\mathrm{F}$ & $(\mathrm{p})$ \\
\hline Uso e tipo de chupeta & 50,256 & 2 & 25,128 & 6,061 & 0,004 * \\
\hline Resíduo & 240,474 & 58 & 4,146 & & \\
\hline Total & 290,730 & 60 & & & \\
\hline
\end{tabular}

TABELA B 2.2 - Análise de variância para a variável "Distância intercanina superior - Cervical (mm)"

\begin{tabular}{lccccc}
\hline $\begin{array}{l}\text { Fonte de } \\
\text { variação }\end{array}$ & Soma de quadrados & $\begin{array}{c}\text { Graus de } \\
\text { liberdade }\end{array}$ & $\begin{array}{c}\text { Quadrado } \\
\text { Médio }\end{array}$ & F & $\begin{array}{c}\text { Nível } \\
\text { descritivo } \\
(\mathrm{p})\end{array}$ \\
\hline $\begin{array}{l}\text { Uso e tipo de } \\
\text { chupeta }\end{array}$ & 27,601 & 2 & 13,800 & 4,454 & $0,016^{*}$ \\
\hline Resíduo & 179,711 & 58 & 3,098 & & \\
\hline Total & 207,311 & 60 & & & \\
\hline
\end{tabular}

TABELA B 2.3 - Análise de variância para a variável "Distância intercanina do arco inferior - Ponta da cúspide (mm)"

\begin{tabular}{lccccc}
\hline $\begin{array}{l}\text { Fonte de } \\
\text { variação }\end{array}$ & Soma de quadrados & $\begin{array}{c}\text { Graus de } \\
\text { liberdade }\end{array}$ & $\begin{array}{c}\text { Quadrado } \\
\text { Médio }\end{array}$ & F & $\begin{array}{c}\text { Nível } \\
\text { descritivo } \\
(\mathrm{p})\end{array}$ \\
\hline $\begin{array}{l}\text { Uso e tipo de } \\
\text { chupeta }\end{array}$ & 2,359 & 2 & 1,180 & 0,470 & 0,628 \\
\hline Resíduo & 145,657 & 58 & 2,511 & & \\
\hline Total & 148,016 & 60 & & & \\
\hline
\end{tabular}


TABELA B 2.4 - Análise de variância para a variável "Distância intercanina do arco inferior - Cervical (mm)"

\begin{tabular}{lccccc}
\hline Fonte de variação & $\begin{array}{c}\text { Soma de } \\
\text { quadrados }\end{array}$ & $\begin{array}{c}\text { Graus de } \\
\text { liberdade }\end{array}$ & $\begin{array}{c}\text { Quadrado } \\
\text { Médio }\end{array}$ & \multicolumn{1}{c}{$\begin{array}{c}\text { Nível } \\
\text { descritivo } \\
(\mathrm{p})\end{array}$} \\
\hline Uso e tipo de chupeta & 1,656 & 2 & 0,828 & 0,291 & 0,749 \\
\hline Resíduo & 165,278 & 58 & 2,850 & & \\
\hline Total & 166,934 & 60 & & & \\
\hline
\end{tabular}

3. Tabelas descritivas das variáveis da avaliação dos arcos dentais segundo a variável "Como suga" (distribuições percentuais das variáveis categorizadas e estatísticas descritivas das variáveis quantitativas da avaliação dos arcos dentais, segundo a variável "Uso e tipo de chupeta").

TABELA B 3.1 - Distribuição das freqüências da variável "Desvio de linha média" segundo a variável "Como suga"

\begin{tabular}{|c|c|c|c|c|}
\hline \multirow[b]{2}{*}{ Como suga } & \multicolumn{3}{|c|}{ Desvio de linha média } & \multirow[b]{2}{*}{ Total } \\
\hline & Não & Lado direito & Lado esquerdo & \\
\hline Suga sempre & $\begin{array}{c}61,5 \% \\
(8) \\
\end{array}$ & $\begin{array}{c}15,4 \% \\
(2) \\
\end{array}$ & $\begin{array}{c}23,1 \% \\
(3) \\
\end{array}$ & $\begin{array}{c}100,0 \% \\
(n=13) \\
\end{array}$ \\
\hline Suga às vezes & $\begin{array}{c}76,5 \% \\
(13) \\
\end{array}$ & $\begin{array}{c}17,6 \% \\
(3) \\
\end{array}$ & $\begin{array}{c}5,9 \% \\
(1) \\
\end{array}$ & $\begin{array}{c}100,0 \% \\
(n=17) \\
\end{array}$ \\
\hline Apóia & $\begin{array}{c}66,7 \% \\
(2)\end{array}$ & $\begin{array}{c}0,0 \% \\
(0)\end{array}$ & $\begin{array}{c}33,3 \% \\
(1)\end{array}$ & $\begin{array}{c}100,0 \% \\
(n=3)\end{array}$ \\
\hline Total & $\begin{array}{c}69,7 \% \\
(23) \\
\end{array}$ & $\begin{array}{c}15,2 \% \\
(5) \\
\end{array}$ & $\begin{array}{c}15,2 \% \\
(5) \\
\end{array}$ & $\begin{array}{c}100,0 \% \\
(n=33)\end{array}$ \\
\hline
\end{tabular}


TABELA B 3.2 - Distribuição das freqüências da variável "Relação canina lado direito" segundo a variável "Como suga"

\begin{tabular}{lccc}
\hline & \multicolumn{2}{c}{ Relação canina lado direito } & \\
\cline { 2 - 3 } Como suga & Relação Classe I & Relação Classe II & Total \\
\hline \multirow{2}{*}{ Suga sempre } & $23,1 \%$ & $76,9 \%$ & $100,0 \%$ \\
& $(3)$ & $(10)$ & $(\mathrm{n}=13)$ \\
\hline & $52,9 \%$ & $47,1 \%$ & $100,0 \%$ \\
Suga às vezes & $(9)$ & $(8)$ & $(\mathrm{n}=17)$ \\
\hline & $0,0 \%$ & $100,0 \%$ & $100,0 \%$ \\
Apóia & $(0)$ & $(3)$ & $(\mathrm{n}=3)$ \\
\hline & $36,4 \%$ & $63,6 \%$ & $100,0 \%$ \\
Total & $(12)$ & $(21)$ & $(\mathrm{n}=33)$ \\
\hline
\end{tabular}

TABELA B 3.3 - Distribuição das freqüências da variável "Relação canina lado esquerdo" segundo a variável "Como suga"

\begin{tabular}{lccc}
\hline & \multicolumn{2}{c}{ Relação canina lado esquerdo } & \\
\cline { 2 - 3 } Como suga & Relação Classe I & Relação Classe II & Total \\
\hline \multirow{2}{*}{ Suga sempre } & $53,8 \%$ & $46,2 \%$ & $100,0 \%$ \\
\hline & $(7)$ & $(6)$ & $(\mathrm{n}=13)$ \\
\hline Suga às vezes & $58,8 \%$ & $41,2 \%$ & $100,0 \%$ \\
Apóia & $(10)$ & $(7)$ & $(\mathrm{n}=17)$ \\
\hline & $0,0 \%$ & $100,0 \%$ & $100,0 \%$ \\
Total & $(0)$ & $(3)$ & $(\mathrm{n}=3)$ \\
\hline
\end{tabular}


TABELA B 3.4 - Distribuição das freqüências da variável "Mordida cruzada posterior" segundo a variável "Como suga"

\begin{tabular}{|c|c|c|c|c|c|c|}
\hline \multirow[b]{2}{*}{ Como suga } & \multicolumn{5}{|c|}{ Mordida cruzada posterior } & \multirow[b]{2}{*}{ Total } \\
\hline & Não & $\begin{array}{c}\text { Unilatera } \\
\text { lado } \\
\text { direito }\end{array}$ & $\begin{array}{l}\text { Unilateral } \\
\text { lado } \\
\text { esquerdo }\end{array}$ & Bilateral & $\begin{array}{c}\text { Topo a } \\
\text { topo } \\
\text { bilateral }\end{array}$ & \\
\hline Suga sempre & $\begin{array}{c}92,3 \% \\
(12) \\
\end{array}$ & $\begin{array}{c}0,0 \% \\
(0)\end{array}$ & $\begin{array}{c}7,7 \% \\
(1)\end{array}$ & $\begin{array}{c}0,0 \% \\
(0)\end{array}$ & $\begin{array}{c}0,0 \% \\
(0)\end{array}$ & $\begin{array}{c}100,0 \% \\
(n=13)\end{array}$ \\
\hline Suga às vezes & $\begin{array}{c}76,5 \% \\
(13) \\
\end{array}$ & $\begin{array}{c}5,9 \% \\
(1) \\
\end{array}$ & $\begin{array}{c}5,9 \% \\
(1) \\
\end{array}$ & $\begin{array}{c}5,9 \% \\
(1) \\
\end{array}$ & $\begin{array}{c}5,9 \% \\
(1) \\
\end{array}$ & $\begin{array}{c}100,0 \% \\
(n=17)\end{array}$ \\
\hline Apóia & $\begin{array}{c}100,0 \% \\
(3)\end{array}$ & $\begin{array}{c}0,0 \% \\
(0)\end{array}$ & $\begin{array}{c}0,0 \% \\
(0)\end{array}$ & $\begin{array}{c}0,0 \% \\
(0)\end{array}$ & $\begin{array}{c}0,0 \% \\
(0)\end{array}$ & $\begin{array}{c}100,0 \% \\
(n=3)\end{array}$ \\
\hline Total & $\begin{array}{c}84,8 \% \\
(28)\end{array}$ & $\begin{array}{c}3,0 \% \\
(1)\end{array}$ & $\begin{array}{c}6,1 \% \\
(2)\end{array}$ & $\begin{array}{c}3,0 \% \\
(1)\end{array}$ & $\begin{array}{c}3,0 \% \\
(1)\end{array}$ & $\begin{array}{c}100,0 \% \\
(n=33)\end{array}$ \\
\hline
\end{tabular}

TABELA B 3.5 - Distribuição das freqüências da variável "Mordida aberta posterior" segundo a variável "Como suga"

\begin{tabular}{|c|c|c|c|}
\hline \multirow[b]{2}{*}{ Como suga } & \multicolumn{2}{|c|}{ Mordida aberta posterior } & \multirow[b]{2}{*}{ Total } \\
\hline & Sim & Não & \\
\hline Suga sempre & $\begin{array}{c}0,0 \% \\
(0)\end{array}$ & $\begin{array}{c}100,0 \% \\
(13)\end{array}$ & $\begin{array}{c}100,0 \% \\
(n=13)\end{array}$ \\
\hline Suga às vezes & $\begin{array}{c}0,0 \% \\
(0)\end{array}$ & $\begin{array}{c}100,0 \% \\
(17)\end{array}$ & $\begin{array}{c}100,0 \% \\
(n=17)\end{array}$ \\
\hline Apóia & $\begin{array}{c}0,0 \% \\
(0)\end{array}$ & $\begin{array}{c}100,0 \% \\
\text { (3) }\end{array}$ & $\begin{array}{c}100,0 \% \\
(n=3)\end{array}$ \\
\hline Total & $\begin{array}{c}0,0 \% \\
(0)\end{array}$ & $\begin{array}{c}100,0 \% \\
(33)\end{array}$ & $\begin{array}{c}100,0 \% \\
(n=33)\end{array}$ \\
\hline
\end{tabular}


TABELA B.3.6 - Distribuição das freqüências da variável "Sobressaliência normal" segundo a variável "Como suga"

\begin{tabular}{|c|c|c|c|}
\hline \multirow[b]{2}{*}{ Como suga } & \multicolumn{2}{|c|}{ Sobressaliência normal } & \multirow[b]{2}{*}{ Total } \\
\hline & Sim & Não & \\
\hline & $23,1 \%$ & $76,9 \%$ & $100,0 \%$ \\
\hline \multirow[t]{2}{*}{ Suga sempre } & (3) & $(10)$ & $(n=13)$ \\
\hline & $56,3 \%$ & $43,8 \%$ & $100,0 \%$ \\
\hline \multirow[t]{2}{*}{ Suga æ̀s vezes } & $(9)$ & $(7)$ & $(n=16)$ \\
\hline & $33,3 \%$ & $66,7 \%$ & $100,0 \%$ \\
\hline \multirow[t]{2}{*}{ Apóia } & $(1)$ & $(2)$ & $(n=3)$ \\
\hline & $40,6 \%$ & $59,4 \%$ & $100,0 \%$ \\
\hline Total & $(13)$ & $(19)$ & $(n=32)$ \\
\hline
\end{tabular}

Obs.: Foram desconsideradas as crianças com sobressaliência negativa

TABELA B 3.7 - Distribuição das freqüências da variável "Sobremordida" segundo a variável "Como suga"

\begin{tabular}{lccccc}
\hline & \multicolumn{5}{c}{ Sobremordida } \\
\cline { 2 - 5 } Como suga & $\begin{array}{c}50 \% \text { ou } \\
\text { menos }\end{array}$ & $\begin{array}{c}\text { mais que } \\
50 \%\end{array}$ & $\begin{array}{c}\text { Topo a } \\
\text { topo }\end{array}$ & $\begin{array}{c}\text { Mordida } \\
\text { aberta }\end{array}$ & Total \\
\hline \multirow{5}{*}{ Suga sempre } & $23,1 \%$ & $7,7 \%$ & $7,7 \%$ & $61,5 \%$ & $100,0 \%$ \\
\hline \multirow{4}{*}{ Suga æ̀s vezes } & $(3)$ & $(1)$ & $(1)$ & $(8)$ & $(\mathrm{n}=13)$ \\
\hline \multirow{3}{*}{ Apóia } & $35,3 \%$ & $17,6 \%$ & $11,8 \%$ & $35,3 \%$ & $100,0 \%$ \\
& $(6)$ & $(3)$ & $(2)$ & $(6)$ & $(\mathrm{n}=17)$ \\
\hline & $0,0 \%$ & $0,0 \%$ & $0,0 \%$ & $100,0 \%$ & $100,0 \%$ \\
Total & $(0)$ & $(0)$ & $(0)$ & $(3)$ & $(\mathrm{n}=3)$ \\
\hline & $27,3 \%$ & $12,1 \%$ & $9,1 \%$ & $51,5 \%$ & $100,0 \%$ \\
& $(9)$ & $(4)$ & $(3)$ & $(17)$ & $(\mathrm{n}=33)$ \\
\hline
\end{tabular}


TABELA B 3.8 - Estatística descritiva da variável "Quanto de mordida aberta (mm)" segundo a variável "Como suga"

\begin{tabular}{lcccccc}
\hline Como suga & $\mathrm{n}$ & Média & $\begin{array}{c}\text { Desvio } \\
\text { Padrão }\end{array}$ & Mínimo & Máximo & Mediana \\
\hline Suga sempre & 8 & 6,5 & 2,88 & 1,0 & 10,0 & 7,0 \\
\hline Suga æ̀̀ vezes & 6 & 5,3 & 2,19 & 3,0 & 8,5 & 5,0 \\
\hline Apóia & 3 & 4,7 & 3,51 & 1,0 & 8,0 & 5,0 \\
\hline
\end{tabular}

TABELA B 3.9 - Estatística descritiva da variável "Distância intercanina do arco superior- Ponta da cúspide (mm)" segundo a variável "Como suga"

\begin{tabular}{lcccccc}
\hline Como suga & $\mathrm{n}$ & Média & $\begin{array}{c}\text { Desvio } \\
\text { Padrão }\end{array}$ & Mínimo & Máximo & Mediana \\
\hline Suga sempre & 13 & 30,0 & 1,80 & 28,0 & 33,0 & 30,5 \\
\hline Suga æ̀s vezes & 17 & 29,0 & 2,38 & 23,5 & 33,0 & 29,0 \\
\hline Apóia & 3 & 28,2 & 2,36 & 25,5 & 30,0 & 29,0 \\
\hline
\end{tabular}

TABELA B 3.10 - Estatística descritiva da variável "Distância intercanina do arco superior- Cervical (mm)" segundo a variável "Como suga"

\begin{tabular}{lcccccc}
\hline Como suga & $\mathrm{n}$ & Média & $\begin{array}{c}\text { Desvio } \\
\text { Padrão }\end{array}$ & Mínimo & Máximo & Mediana \\
\hline Suga sempre & 13 & 24,3 & 1,96 & 22,0 & 28,0 & 24,0 \\
\hline Suga æ̀s vezes & 17 & 24,3 & 2,11 & 20,0 & 29,0 & 24,0 \\
\hline Apóia & 3 & 23,7 & 1,53 & 22,0 & 25,0 & 24,0 \\
\hline
\end{tabular}

TABELA B 3.11 - Estatística descritiva da variável "Distância intercanina do arco inferior- Ponta da cúspide (mm)" segundo a variável "Como suga"

\begin{tabular}{lcccccc}
\hline Como suga & $\mathrm{n}$ & Média & $\begin{array}{c}\text { Desvio } \\
\text { Padrão }\end{array}$ & Mínimo & Máximo & Mediana \\
\hline Suga sempre & 13 & 25,4 & 1,71 & 22,0 & 28,0 & 26,0 \\
\hline Suga æ̀s vezes & 17 & 25,4 & 1,13 & 23,0 & 26,5 & 26,0 \\
\hline Apóia & 3 & 25,8 & 2,25 & 23,5 & 28,0 & 26,0 \\
\hline
\end{tabular}


TABELA B 3.12 - Estatística descritiva da variável "Distância intercanina do arco inferior- Cervical (mm)" segundo a variável "Como suga"

\begin{tabular}{lcccccc}
\hline Como suga & $\mathrm{n}$ & Média & $\begin{array}{c}\text { Desvio } \\
\text { Padrão }\end{array}$ & Mínimo & Máximo & Mediana \\
\hline Suga sempre & 13 & 20,7 & 2,25 & 19,0 & 26,0 & 20,0 \\
\hline Suga æ̀s vezes & 17 & 20,6 & 1,22 & 19,0 & 23,0 & 20,5 \\
\hline Apóia & 3 & 20,3 & 1,53 & 19,0 & 22,0 & 20,0 \\
\hline
\end{tabular}

\section{Tabelas da análise inferencial das variáveis da avaliação dos arcos} dentais segundo a variável "Como suga" (Análises de Variância das variáveis quantitativas com fator "Como suga").

TABELA B 4.1 - Análise de variância para a variável "Quanto de mordida aberta (mm)", com fator "Como suga"

\begin{tabular}{lccccc}
\hline & & \multicolumn{2}{c}{} & & \multicolumn{2}{c}{ Nível } \\
Fonte de variação & Soma de quadrados & $\begin{array}{c}\text { Graus de } \\
\text { liberdade }\end{array}$ & $\begin{array}{c}\text { Quadrado } \\
\text { Médio }\end{array}$ & \multicolumn{1}{c}{$\begin{array}{c}\text { descritivo } \\
(p)\end{array}$} \\
\hline Como suga & 9,517 & 2 & 4,759 & 0,625 & 0,549 \\
\hline Resíduo & 106,542 & 14 & 7,610 & & \\
\hline Total & 116,059 & 16 & & & \\
\hline
\end{tabular}

TABELA B 4.2 - Análise de variância para a variável "Distância intercanina do arco superior - Ponta da cúspide (mm)", com fator "Como suga"

\begin{tabular}{|c|c|c|c|c|c|}
\hline Fonte de variação & Soma de quadrados & $\begin{array}{l}\text { Graus de } \\
\text { liberdade }\end{array}$ & $\begin{array}{c}\text { Quadrado } \\
\text { Médio }\end{array}$ & $\mathrm{F}$ & $\begin{array}{c}\text { Nível } \\
\text { descritivo } \\
(p)\end{array}$ \\
\hline Como suga & 12,436 & 2 & 6,218 & 1,329 & 0,280 \\
\hline$\underline{\text { Resíduo }}$ & 140,397 & 30 & 4,680 & & \\
\hline Total & 152,833 & 32 & & & \\
\hline
\end{tabular}


TABELA B 4.3 - Análise de variância para a variável "Distância intercanina do arco superior - Cervical (mm)", com fator "Como suga"

\begin{tabular}{|c|c|c|c|c|c|}
\hline Fonte de variação & Soma de quadrados & $\begin{array}{l}\text { Graus de } \\
\text { liberdade }\end{array}$ & $\begin{array}{c}\text { Quadrado } \\
\text { Médio }\end{array}$ & $\mathrm{F}$ & $\begin{array}{c}\text { Nível } \\
\text { descritivo } \\
(\mathrm{p})\end{array}$ \\
\hline Como suga & 1,095 & 2 & 0,548 & 0,135 & 0,874 \\
\hline Resíduo & 121,965 & 30 & 4,066 & & \\
\hline Total & 123,061 & 32 & & & \\
\hline
\end{tabular}

TABELA B 4.4 - Análise de variância para a variável "Distância intercanina do arco inferior - Ponta da cúspide (mm)", com fator "Como suga"

\begin{tabular}{|c|c|c|c|c|c|}
\hline Fonte de variação & Soma de quadrados & $\begin{array}{l}\text { Graus de } \\
\text { liberdade }\end{array}$ & $\begin{array}{l}\text { Quadrado } \\
\text { Médio }\end{array}$ & $\mathrm{F}$ & $\begin{array}{c}\text { Nível } \\
\text { descritivo } \\
(p)\end{array}$ \\
\hline Como suga & 0,552 & 2 & 0,276 & 0,126 & 0,882 \\
\hline Resíduo & 65,508 & 30 & 2,184 & & \\
\hline Total & 66,061 & 32 & & & \\
\hline
\end{tabular}

TABELA B 4.5 - Análise de variância para a variável "Distância intercanina do arco inferior - Cervical (mm)", com fator "Como suga"

\begin{tabular}{lccccc}
\hline & & \multicolumn{2}{c}{ Graus de } & Quadrado & \multicolumn{2}{c}{$\begin{array}{c}\text { Nível } \\
\text { descritivo } \\
\text { Fonte de variação }\end{array}$} & Soma de quadrados & $\begin{array}{c}\text { liberdade } \\
\text { Médio }\end{array}$ & $\mathrm{F}$ & \begin{tabular}{c}
$\mathrm{p})$ \\
\hline Como suga
\end{tabular} & 0,315 & 2 & 0,157 & 0,053 & 0,949 \\
\hline Resíduo & 89,201 & 30 & 2,973 & & \\
\hline Total & 89,515 & 32 & & & \\
\hline
\end{tabular}


ANEXO C

\section{AVALIAÇÃO DAS ESTRUTURAS MIOFUNCIONAIS ORAIS}

1. Tabelas descritivas das variáveis da avaliação das estruturas miofuncionais orais segundo a variável "Uso e tipo de chupeta" (distribuições percentuais das variáveis categorizadas).

TABELA C 1.1 - Distribuição das freqüências da variável "Lábios Mobilidade" segundo a variável "Uso e tipo de chupeta"

\begin{tabular}{lccc}
\hline \multirow{2}{*}{ Uso e tipo de chupeta } & \multicolumn{2}{c}{ Lábios - Mobilidade } & \multirow{2}{*}{ Total } \\
\cline { 2 - 3 } & Normal & Não normal & \\
\hline Nunca usou & $81,5 \%$ & $18,5 \%$ & $100,0 \%$ \\
& $(22)$ & $(5)$ & $(\mathrm{n}=27)$ \\
\hline Usa ortodôntica & $70,0 \%$ & $30,0 \%$ & $100,0 \%$ \\
& $(14)$ & $(6)$ & $(\mathrm{n}=20)$ \\
\hline Usa comum & $92,9 \%$ & $7,1 \%$ & $100,0 \%$ \\
& $(13)$ & $(1)$ & $(\mathrm{n}=14)$ \\
\hline Total & $80,3 \%$ & $19,7 \%$ & $100,0 \%$ \\
& $(49)$ & $(12)$ & $(\mathrm{n}=61)$ \\
\hline
\end{tabular}

TABELA C 1.2 - Distribuição das freqüências da variável "Língua - Aspecto" segundo a variável "Uso e tipo de chupeta"

\begin{tabular}{lcc}
\hline & Língua - Aspecto & Total \\
\cline { 2 - 3 } Uso e tipo de chupeta & Normal & $100,0 \%$ \\
Nunca usou & $100,0 \%$ & $(\mathrm{n}=27)$ \\
\hline Usa ortodôntica & $(27)$ & $100,0 \%$ \\
& $100,0 \%$ & $(\mathrm{n}=20)$ \\
\hline Usa comum & $(20)$ & $100,0 \%$ \\
& $100,0 \%$ & $(\mathrm{n}=14)$ \\
\hline Total & $(14)$ & $100,0 \%$ \\
& $100,0 \%$ & $(\mathrm{n}=61)$ \\
\hline
\end{tabular}


TABELA C 1.3 - Distribuição das freqüências da variável "Língua -

Tonicidade" segundo a variável "Uso e tipo de chupeta"

\begin{tabular}{lccc}
\hline \multirow{2}{*}{ Uso e tipo de chupeta } & \multicolumn{2}{c}{ Língua - Tonicidade } & \multirow{2}{*}{ Total } \\
\cline { 2 - 3 } Nunca usou & Normal & Hipotônica & $100,0 \%$ \\
& $77,8 \%$ & $22,2 \%$ & $(\mathrm{n}=27)$ \\
\hline Usa ortodôntica & $(21)$ & $(6)$ & $100,0 \%$ \\
& $80,0 \%$ & $20,0 \%$ & $(\mathrm{n}=20)$ \\
\hline Usa comum & $(16)$ & $(4)$ & $100,0 \%$ \\
& $78,6 \%$ & $21,4 \%$ & $(\mathrm{n}=14)$ \\
\hline Total & $(11)$ & $(3)$ & $100,0 \%$ \\
& $78,7 \%$ & $21,3 \%$ & $(\mathrm{n}=61)$ \\
\hline
\end{tabular}

TABELA C 1.4 - Distribuição das freqüências da variável "Língua Mobilidade" segundo a variável "Uso e tipo de chupeta"

\begin{tabular}{lccc}
\hline & \multicolumn{2}{c}{ Língua - Mobilidade } & \\
\cline { 2 - 3 } Uso e tipo de chupeta & Normal & Não normal & Total \\
\hline Nunca usou & $81,5 \%$ & $18,5 \%$ & $100,0 \%$ \\
& $(22)$ & $(5)$ & $(\mathrm{n}=27)$ \\
\hline Usa ortodôntica & $75,0 \%$ & $25,0 \%$ & $100,0 \%$ \\
& $(15)$ & $(5)$ & $(\mathrm{n}=20)$ \\
\hline Usa comum & $85,7 \%$ & $14,3 \%$ & $100,0 \%$ \\
& $(12)$ & $(2)$ & $(\mathrm{n}=14)$ \\
\hline Total & $80,3 \%$ & $19,7 \%$ & $100,0 \%$ \\
& $(49)$ & $(12)$ & $(\mathrm{n}=61)$ \\
\hline
\end{tabular}

TABELA C 1.5 - Distribuição das freqüências da variável "Bochecha Tonicidade" segundo a variável "Uso e tipo de chupeta"

\begin{tabular}{|c|c|c|c|}
\hline \multirow[b]{2}{*}{ Uso e tipo de chupeta } & \multicolumn{2}{|c|}{ Bochecha - Tonicidade } & \multirow[b]{2}{*}{ Total } \\
\hline & Normal & Hipotonicidade & \\
\hline \multirow[t]{2}{*}{ Nunca usou } & $77,8 \%$ & $22,2 \%$ & \\
\hline & $(21)$ & $(6)$ & $100,0 \%(n=27)$ \\
\hline \multirow[t]{2}{*}{ Usa ortodôntica } & $65,0 \%$ & $35,0 \%$ & \\
\hline & $(13)$ & $(7)$ & $100,0 \%(n=20)$ \\
\hline \multirow[t]{2}{*}{ Usa comum } & $64,3 \%$ & $35,7 \%$ & \\
\hline & $(9)$ & $(5)$ & $100,0 \%(n=14)$ \\
\hline \multirow[t]{2}{*}{ Total } & $70,5 \%$ & $29,5 \%$ & \\
\hline & $(43)$ & $(18)$ & $100,0 \%(n=61)$ \\
\hline
\end{tabular}


TABELA C 1.6 - Distribuição das freqüências da variável "Bochecha Mobilidade" segundo a variável "Uso e tipo de chupeta"

\begin{tabular}{lcccc}
\hline \multirow{2}{*}{$\begin{array}{c}\text { Uso e tipo de } \\
\text { chupeta }\end{array}$} & Normal & Somente infla & $\begin{array}{c}\text { Recusou-se a } \\
\text { fazer o exercício }\end{array}$ & Total \\
\cline { 2 - 4 } & $74,1 \%$ & $22,2 \%$ & $3,7 \%$ & $100,0 \%$ \\
& $(20)$ & $(6)$ & $(1)$ & $(\mathrm{n}=27)$ \\
\hline Nunca usou & $35,0 \%$ & $55,0 \%$ & $10,0 \%$ & $100,0 \%$ \\
& $(7)$ & $(11)$ & $(2)$ & $(\mathrm{n}=20)$ \\
\hline Usa ortodôntica & $35,7 \%$ & $64,3 \%$ & $0,0 \%$ & $100,0 \%$ \\
& $(5)$ & $(9)$ & $(0)$ & $(\mathrm{n}=14)$ \\
\hline Total comum & $52,5 \%$ & $42,6 \%$ & $4,9 \%$ & $100,0 \%$ \\
& $(32)$ & $(26)$ & $(3)$ & $(\mathrm{n}=61)$ \\
\hline
\end{tabular}

TABELA C 1.7 - Distribuição das freqüências da variável "Palato duro" segundo a variável "Uso e tipo de chupeta"

\begin{tabular}{lccccc}
\hline & \multicolumn{5}{c}{ Palato duro } \\
\cline { 2 - 5 } Uso e tipo de chupeta & Normal & Estreito & Alto & $\begin{array}{c}\text { Estreito } \\
\text { alto }\end{array}$ & Total \\
\hline Nunca usou & $77,8 \%$ & $7,4 \%$ & $14,8 \%$ & $0,0 \%$ & $100,0 \%$ \\
& $(21)$ & $(2)$ & $(4)$ & $(0)$ & $(\mathrm{n}=27)$ \\
\hline Usa ortodôntica & $75,0 \%$ & $10,0 \%$ & $10,0 \%$ & $5,0 \%$ & $100,0 \%$ \\
& $(15)$ & $(2)$ & $(2)$ & $(1)$ & $(\mathrm{n}=20)$ \\
\hline Usa comum & $35,7 \%$ & $42,9 \%$ & $14,3 \%$ & $7,1 \%$ & $100,0 \%$ \\
& $(5)$ & $(6)$ & $(2)$ & $(1)$ & $(\mathrm{n}=14)$ \\
\hline Total & $67,2 \%$ & $16,4 \%$ & $13,1 \%$ & $3,3 \%$ & $100,0 \%$ \\
& $(41)$ & $(10)$ & $(8)$ & $(2)$ & $(\mathrm{n}=61)$ \\
\hline
\end{tabular}

2. Tabelas descritivas das variáveis da avaliação miofuncional oral segundo a variável "Como suga" (distribuições percentuais das variáveis categorizadas) 
TABELA C 2.1 - Distribuição das freqüências da variável "Lábios - Aspecto" segundo a variável "Como suga"

\begin{tabular}{|c|c|c|c|c|c|c|c|}
\hline \multirow[b]{2}{*}{ Como suga } & \multicolumn{7}{|c|}{ Lábios - Aspecto } \\
\hline & Normal & $\begin{array}{c}\text { Entreaber } \\
\text { tos }\end{array}$ & $\begin{array}{l}\text { Vermelhão } \\
\text { r aparente e } \\
\text { entreabertos }\end{array}$ & $\begin{array}{l}\text { Ocluídos } \\
\text { com } \\
\text { tensão e } \\
\text { vermelhão } \\
\text { aparente }\end{array}$ & $\begin{array}{c}\text { Altern } \\
\text { ado }\end{array}$ & $\begin{array}{l}\text { Alternado } \\
\text { com } \\
\text { vermelhão }\end{array}$ & Total \\
\hline $\begin{array}{l}\text { Suga } \\
\text { sempre }\end{array}$ & $\begin{array}{c}46,2 \% \\
(6)\end{array}$ & $\begin{array}{c}0,0 \% \\
(0)\end{array}$ & $\begin{array}{c}7,7 \% \\
(1)\end{array}$ & $\begin{array}{c}7,7 \% \\
(1)\end{array}$ & $\begin{array}{c}23,1 \% \\
\text { (3) }\end{array}$ & $\begin{array}{c}15,4 \% \\
\text { (2) }\end{array}$ & $\begin{array}{c}100,0 \% \\
(n=13)\end{array}$ \\
\hline $\begin{array}{l}\text { Suga às } \\
\text { vezes }\end{array}$ & $\begin{array}{c}58,8 \% \\
(10)\end{array}$ & $\begin{array}{c}23,5 \% \\
(4)\end{array}$ & $\begin{array}{c}11,8 \% \\
(2)\end{array}$ & $\begin{array}{c}0,0 \% \\
(0)\end{array}$ & $\begin{array}{c}5,9 \% \\
(1)\end{array}$ & $\begin{array}{c}0,0 \% \\
(0)\end{array}$ & $\begin{array}{c}100,0 \% \\
(n=17)\end{array}$ \\
\hline Apóia & $\begin{array}{c}0,0 \% \\
(0)\end{array}$ & $\begin{array}{l}33,3 \% \\
(1)\end{array}$ & $\begin{array}{l}33,3 \% \\
(1)\end{array}$ & $\begin{array}{c}0,0 \% \\
(0)\end{array}$ & $\begin{array}{c}33,3 \% \\
(1)\end{array}$ & $\begin{array}{c}0,0 \% \\
(0)\end{array}$ & $\begin{array}{c}100,0 \% \\
(n=3)\end{array}$ \\
\hline Total & $\begin{array}{c}48,5 \% \\
(16)\end{array}$ & $\begin{array}{c}15,2 \% \\
(5)\end{array}$ & $\begin{array}{c}12,1 \% \\
(4)\end{array}$ & $\begin{array}{c}3,0 \% \\
(1)\end{array}$ & $\begin{array}{c}15,2 \% \\
(5)\end{array}$ & $\begin{array}{c}6.1 \% \\
(2)\end{array}$ & $\begin{array}{l}100,0 \% \\
(n=33)\end{array}$ \\
\hline
\end{tabular}

TABELA C 2.2 - Distribuição das freqüências da variável "Lábios -

Tonicidade" segundo a variável "Como suga"

\begin{tabular}{lcccccc} 
& \multicolumn{5}{c}{ Lábios - Tonicidade } & \\
\cline { 2 - 6 } Como & \multicolumn{5}{c}{ Hipotonici } \\
dade & Hipotonicida & $\begin{array}{c}\text { Hipotonicidade } \\
\text { de ambos os } \\
\text { suga }\end{array}$ & Normal & superior & Hipertonicida & de inferior \\
Suga & $61,5 \%$ & $15,4 \%$ & $0,0 \%$ & $23,1 \%$ & $0,0 \%$ & Total \\
\hline Sempre & $(8)$ & $(2)$ & $(0)$ & $(3)$ & $(0)$ & $100,0 \%$ \\
Suga æ̇ & $47,1 \%$ & $17,6 \%$ & $5,9 \%$ & $17,6 \%$ & $11,8 \%$ & $100,0 \%$ \\
vezes & $(8)$ & $(3)$ & $(1)$ & $(3)$ & $(2)$ & $(\mathrm{n}=17)$ \\
\hline & $33,3 \%$ & $33,3 \%$ & $0,0 \%$ & $33,3 \%$ & $0,0 \%$ & $100,0 \%$ \\
Apóia & $(1)$ & $(1)$ & $(0)$ & $(1)$ & $(0)$ & $(\mathrm{n}=3)$ \\
\hline & $51,5 \%$ & $18,2 \%$ & $3,0 \%$ & $21,2 \%$ & $6,1 \%$ & $100,0 \%$ \\
Total & $(17)$ & $(6)$ & $(1)$ & $(7)$ & $(2)$ & $(\mathrm{n}=33)$ \\
\hline
\end{tabular}


TABELA C 2.3 - Distribuição das freqüências da variável "Lábios Mobilidade" segundo a variável "Como suga"

\begin{tabular}{lccc} 
& \multicolumn{2}{c}{ Lábios - Mobilidade } & \\
\cline { 2 - 3 } Como suga & Normal & Não normal & Total \\
\cline { 2 - 3 } Suga sempre & $84,6 \%$ & $15,4 \%$ & $100,0 \%$ \\
Suga às vezes & $(11)$ & $(2)$ & $(\mathrm{n}=13)$ \\
\hline & $76,5 \%$ & $23,5 \%$ & $100,0 \%$ \\
Apóia & $(13)$ & $(4)$ & $(\mathrm{n}=17)$ \\
\hline & $66,7 \%$ & $33,3 \%$ & $100,0 \%$ \\
Total & $(2)$ & $(1)$ & $(\mathrm{n}=3)$ \\
\hline
\end{tabular}

TABELA C 2.4 - Distribuição das freqüências da variável "Língua - Aspecto" segundo a variável "Como suga"

\begin{tabular}{lccc}
\hline \multirow{2}{*}{ Como suga } & \multicolumn{2}{c}{ Língua - Aspecto } & Total \\
\cline { 2 - 3 } & Normal & Manchada & $100,0 \%$ \\
Suga sempre & $100,0 \%$ & $0,0 \%$ & $(\mathrm{n}=13)$ \\
\hline \multirow{2}{*}{ Suga às vezes } & $(13)$ & $(0)$ & $100,0 \%$ \\
& $100,0 \%$ & $0,0 \%$ & $(\mathrm{n}=17)$ \\
Apóia & $(17)$ & $(0)$ & $100,0 \%$ \\
& $100,0 \%$ & $0,0 \%$ & $(\mathrm{n}=3)$ \\
Total & $(3)$ & $(0)$ & $100,0 \%$ \\
& $100,0 \%$ & $0,0 \%$ & $(\mathrm{n}=33)$ \\
\hline
\end{tabular}


TABELA C 2.5 - Distribuição das freqüências da variável "Língua -

Tonicidade" segundo a variável "Como suga"

\begin{tabular}{lccc}
\hline \multirow{2}{*}{ Como suga } & \multicolumn{2}{c}{ Língua - Tonicidade } & \multirow{2}{*}{ Total } \\
\cline { 2 - 3 } & Normal & Hipotônica & $100,0 \%$ \\
Suga sempre & $84,6 \%$ & $15,4 \%$ & $(\mathrm{n}=13)$ \\
\hline \multirow{3}{*}{ Suga æ̀s vezes } & $(11)$ & $(2)$ & $100,0 \%$ \\
& $76,5 \%$ & $23,5 \%$ & $(\mathrm{n}=17)$ \\
Apóia & $(13)$ & $(4)$ & $100,0 \%$ \\
\hline & $100,0 \%$ & $0,0 \%$ & $(\mathrm{n}=3)$ \\
Total & $(3)$ & $(0)$ & $100,0 \%$ \\
& $81,8 \%$ & $18,2 \%$ & $(\mathrm{n}=33)$ \\
\hline
\end{tabular}

TABELA C 2.6 - Distribuição das freqüências da variável "Língua Mobilidade" segundo a variável "Como suga"

\begin{tabular}{lccc}
\hline \multirow{2}{*}{ Como suga } & \multicolumn{2}{c}{ Língua - Mobilidade } & Total \\
\cline { 2 - 3 } & Normal & Não normal & \\
Suga sempre & $84,6 \%$ & $15,4 \%$ & $100,0 \%$ \\
& $(11)$ & $(2)$ & $(\mathrm{n}=13)$ \\
\hline \multirow{3}{*}{ Suga æ̀s vezes } & $76,5 \%$ & $23,5 \%$ & $100,0 \%$ \\
Apóia & $(13)$ & $(4)$ & $(\mathrm{n}=17)$ \\
\hline & $100,0 \%$ & $0,0 \%$ & $100,0 \%$ \\
Total & $(3)$ & $(0)$ & $(\mathrm{n}=3)$ \\
\hline
\end{tabular}


TABELA C 2.7 - Distribuição das freqüências da variável "Bochecha Tonicidade" segundo a variável "Como suga"

\begin{tabular}{lccc}
\hline \multirow{2}{*}{ Como suga } & \multicolumn{2}{c}{ Bochecha - Tonicidade } & \multirow{2}{*}{ Total } \\
\cline { 2 - 3 } Suga sempre & Normal & Hipotonicidade & \\
\hline & $61,5 \%$ & $38,5 \%$ & $100,0 \%$ \\
Suga às vezes & $(8)$ & $(5)$ & $(\mathrm{n}=13)$ \\
\hline & $76,5 \%$ & $23,5 \%$ & $100,0 \%$ \\
Apóia & $(13)$ & $(4)$ & $(\mathrm{n}=17)$ \\
\hline & $33,3 \%$ & $66,7 \%$ & $100,0 \%$ \\
Total & $(1)$ & $(2)$ & $(\mathrm{n}=3)$ \\
\hline
\end{tabular}

TABELA C 2.8 - Distribuição das freqüências da variável "Bochecha Mobilidade" segundo a variável "Como suga"

\begin{tabular}{lcccc}
\hline & \multicolumn{5}{c}{ Bochecha - Mobilidade } \\
\cline { 2 - 4 } Como suga & Normal & Somente infla & $\begin{array}{c}\text { Recusou-se a } \\
\text { fazer o } \\
\text { exercício }\end{array}$ & Total \\
\hline Suga sempre & $38,5 \%$ & $53,8 \%$ & $7,7 \%$ & $100,0 \%$ \\
\hline & $(5)$ & $(7)$ & $(1)$ & $(n=13)$ \\
Suga às vezes & $41,2 \%$ & $52,9 \%$ & $5,9 \%$ & $100,0 \%$ \\
Apóia & $(7)$ & $(9)$ & $(1)$ & $(\mathrm{n}=17)$ \\
\hline & $0,0 \%$ & $100,0 \%$ & $0,0 \%$ & $100,0 \%$ \\
Total & $(0)$ & $(3)$ & $(0)$ & $(\mathrm{n}=3)$ \\
\hline
\end{tabular}


TABELA C 2.9 - Distribuição das freqüências da variável "Simetria" segundo a variável "Como suga"

\begin{tabular}{|c|c|c|c|c|c|}
\hline \multirow[b]{2}{*}{ Como suga } & \multicolumn{4}{|c|}{ Simetria } & \multirow[b]{2}{*}{ Total } \\
\hline & Normal & $\begin{array}{c}\text { Lado } \\
\text { esquerdo }\end{array}$ & $\begin{array}{l}\text { Lado } \\
\text { direito }\end{array}$ & Olheiras & \\
\hline Suga sempre & $\begin{array}{c}76,9 \% \\
(10) \\
\end{array}$ & $\begin{array}{c}0,0 \% \\
(0) \\
\end{array}$ & $\begin{array}{c}23,1 \% \\
(3)\end{array}$ & $\begin{array}{c}0,0 \% \\
(0) \\
\end{array}$ & $\begin{array}{c}100,0 \% \\
(n=13)\end{array}$ \\
\hline Suga às vezes & $\begin{array}{c}58,8 \% \\
(10) \\
\end{array}$ & $\begin{array}{c}17,6 \% \\
(3) \\
\end{array}$ & $\begin{array}{c}23,5 \% \\
(4)\end{array}$ & $\begin{array}{c}0,0 \% \\
(0)\end{array}$ & $\begin{array}{r}100,0 \% \\
(\mathrm{n}=17)\end{array}$ \\
\hline Apóia & $\begin{array}{c}66,0 \% \\
(2) \\
\end{array}$ & $\begin{array}{c}0,0 \% \\
(0)\end{array}$ & $\begin{array}{c}0,0 \% \\
(0)\end{array}$ & $\begin{array}{c}33,3 \% \\
(1)\end{array}$ & $\begin{array}{c}100,0 \% \\
(n=3)\end{array}$ \\
\hline Total & $\begin{array}{c}66,7 \% \\
(22) \\
\end{array}$ & $\begin{array}{c}9,1 \% \\
(3) \\
\end{array}$ & $\begin{array}{c}21,2 \% \\
(7)\end{array}$ & $\begin{array}{c}3,0 \% \\
(1) \\
\end{array}$ & $\begin{array}{c}100,0 \% \\
(n=33)\end{array}$ \\
\hline
\end{tabular}

TABELA C 2.10 - Distribuição das freqüências da variável "Palato duro" segundo a variável "Como suga"

\begin{tabular}{lccccc}
\hline & \multicolumn{5}{c}{ Palato duro } \\
\cline { 2 - 5 } Como suga & Normal & Estreito & Alto & $\begin{array}{c}\text { Estreito e } \\
\text { alto }\end{array}$ & Total \\
\hline \multirow{4}{*}{ Suga sempre } & $61,5 \%$ & $23,1 \%$ & $7,7 \%$ & $7,7 \%$ & $100,0 \%$ \\
\hline \multirow{3}{*}{ Suga æ̀s vezes } & $(8)$ & $(3)$ & $(1)$ & $(1)$ & $(\mathrm{n}=13)$ \\
\hline & $52,9 \%$ & $23,5 \%$ & $17,6 \%$ & $5,9 \%$ & $100,0 \%$ \\
Apóia & $(9)$ & $(4)$ & $(3)$ & $(1)$ & $(\mathrm{n}=17)$ \\
\hline & $66,7 \%$ & $33,3 \%$ & $0,0 \%$ & $0,0 \%$ & $100,0 \%$ \\
Total & $(2)$ & $(1)$ & $(0)$ & $(0)$ & $(\mathrm{n}=3)$ \\
\hline & $57,6 \%$ & $24,2 \%$ & $12,1 \%$ & $6,1 \%$ & $100,0 \%$ \\
& $(19)$ & $(8)$ & $(4)$ & $(2)$ & $(\mathrm{n}=33)$ \\
\hline
\end{tabular}




\section{REFERÊNCIAS BIBLIOGRÁFICAS *}

1. ADAIR, S. M. Non-nutritive sucking habits in infants and preschool children: a review and recommendations for antecipatory guidance. Master Clin Pediatr Dent, v.4, n.4, p. 14-20, Aug./Sept. 1996.

2. ADAIR, S.M.; MILANO, M.; DUSHKU, J.C. Evaluation of the effects of orthodontic pacifiers on the primary dentitions of 24- to 59-month-old children: preliminary study. Pediatr Dent, v.14, n.1, p.13-18, Jan./Feb. 1992.

3. ADAIR, S.M.; MILANO, M.; LORENZO, I.; RUSSELL, C. Effects of current and former pacifier use on the dentition of 24-to 59- month-old children. Pediatric Dent, v.17, n.7, p. 437-444, Nov./Dez.1995.

4. ADIMARI, M. R.W. Considerações sobre os maus hábitos bucais: contribuição ao estudo. São Paulo, 1975. 52 p. Dissertação (Mestrado em Ortodontia) - Faculdade de Odontologia da Universidade de São Paulo.

\footnotetext{
* De acordo com NBR-6023 da Associação Brasileira de Normas Técnicas, 1989. Abreviatura de periódicos segundo "Index to Dental Literature".
} 
5. AGRESTI, A. Categorical Data Analysis. New York: John Wiley. 1990. $558 \mathrm{p}$.

6. AHLGREN, J. EMG studies of lip and cheek activity in sucking habits. Swed Dent J, v. 19, n.3, p.95-101, 1995. [Resumo]

7. ALBEJANTE, M.N. Estudo de alguns aspectos morfológicos e alterações dimensionais do arco dentário decíduo. São Paulo, 1975. 79p. Dissertação (Mestrado em Odontopediatria) - Faculdade de Odontologia da Universidade de São Paulo.

8. ANDERSON, G.C. Pacifiers: the positive side. MCN, v.11, p. 122-124, Mar./Apr. 1986.

9. BACCHI, E.O.S. Hábitos bucais e outros comportamentos considerados nocivos àoclusão dentária - contribuição ao seu estudo. Piracicaba, 1973. 133 p. Dissertação (Mestrado em Ortodontia) - Faculdade de Odontologia de Piracicaba da Universidade Estadual de Campinas.

10. BAER, P.N.; LESTER, M. The thumb, the pacifier, the erupting tooth and a beautiful smile. J Pedod, v. 11, n.2, p. 113- 119, Winter 1987.

11. BAUME, L. J. On the biology of the deciduous and mixed dentition. Schweiz Monatsch f Zahn, v.53, p. 927, 1943. 
12. BAUME, L. J. Physiological tooth migration and its significance for the developlement of occlusion. I. The biogenetic course of the deciduous dentition. J Dent Res, v. 29, n.2, p. 123-132, Apr. 1950.

13. BISHARA, S.E.; JAKOBSEN, J.R.; TREDER,J.; NOWAK, A. Arch width changes from 6 weeks to 45 years of age. Am J Orthod Dentofac Orthod, v.111, n.4, p. 401-409, Apr. 1997.

14. BLACK, B.; KÖVESI, E.; CHUSID, I.J. Hábitos bucais nocivos. Ortodontia, v.23, n.2, p. 40-44, mai./jun. 1990.

15. BOTTER, D.A.; SANDOVAL, M.C.; MATOS, B.C.H. Relatório de análise estatística sobre o projeto: avaliação das alterações nos arcos dentais e fonoaudiológicas, provocadas pelo uso de chupetas ortodônticas ou não ortodônticas, em crianças com dentição decídua completa. São Paulo: IME-USP, 2000. 46 p.

16. BOWDEN, B.D. A longitudinal study of the effects of digit- and fingersucking. Am J Orthod, v.52, n.12, p.887-901, Dec. 1966a.

17. BOWDEN, B.D. The effects of digital and dummy sucking on arch widths, overbite, and overjet: a longitudinal study. Aust Dent J, v. 11, n.6, p.396-404, Dec. 1966b. 
18. BRUNNER, V. Estudo da relação entre tipos de arcos (I, II e misto) e espaços primatas em crianças caucasóides na faixa etária de 3 a 6 anos de idade. São Paulo, 1982. 49p. Dissertação (Mestrado em Odontopediatria) - Faculdade de Odontologia da Universidade de São Paulo.

19. BRUNNER, V. Estudo da relação terminal dos segundos molares decíduos (plano vertical, degrau mesial e degrau distal para a mandíbula) e relação incisal (sobremordida e sobressaliência), em crianças caucasóide, na faixa etária de 3 a 6 anos. São Paulo, 1990. 83p. Tese (Doutorado em Odontopediatria) Faculdade de Odontologia da Universidade de São Paulo.

20. CAMARGO, M.C.F. Programa preventivo e interceptativo de maloclusões na primeira infância. In: CORRÊA, M.S.N.P. Odontopediatria na primeira infância. São Paulo: Santos, 1998. p. $139-163$

21. CAMARGO, M.C.F.; MODESTO, A.; COSER, R.M. Uso racional da chupeta. J Bras Odontopediatr Odontol Bebê, v.1, n.3, p.44-47, 1998.

22. CARVALHO, M.P. A fonoaudiologia e suas relações com a odontopediatria. In: GUEDES-PINTO, A.C. Odontopediatria. 6. ed. São Paulo: Santos. 1997. p. 855-874. 
23. CHAN, C.; SANTOS-PINTO, A.; MARTINS, J.C.R.; MENDES, A.J.D.; SAKIMA, P.R.T. Estudo cefalométrico dos efeitos esqueléticos e dentários do hábito persistente de sucção de chupeta. Rev Odontol UNESP, v. 25, p.171-182, 1996. Número especial.

24. COELI, B.M.; TOLEDO, O.A. Hábitos bucais de sucção: aspectos relacionados com a etiologia e com o tratamento. $\mathbf{R e v}$ Odontopediatr, v.3, n.1, p.43-51, jan./mar. 1994.

25. COLETTI, J.M.; BARTHOLOMEU, J.A.L. Hábitos nocivos de sucção de dedo e/ou chupeta: etiologia e remoção do hábito. J Bras Odontopediatr Odontol Bebê, v. 1, n.3, p. 57-73, 1998.

26. COLOMA, M.G.G.; CHELOTTI, A.; MATSON, E. Estudo comparativo das distâncias intercaninas e intermolares, em arcos tipo I e II de Baume, na faixa etária de 3 a 5 anos. Rev Fac Odontol S Paulo, v. 23, n.2, p. 121-128, jul./dez. 1985 .

27. CUNHA, S. R. T.; CORRÊA, M.S.N.P.; OLIVEIRA, P.M.L.; SCHALKA, M.M.S. Hábitos bucais. In: CORRÊA, M.S.N.P. Odontopediatria na primeira infância. São Paulo: Santos , 1998. p. 561- 576.

28. DADALTO, E.C.V. Hábitos de sucção de dedo e/ou chupeta: estudo seccional. Rio de Janeiro, 1989. 163 p. Dissertação (Mestrado em Odontopediatria) - Faculdade de Odontologia da Universidade Federal do Rio de Janeiro. [Resumo] 
29. ESPINDOLA, V.P.; SANCHEZ, A.L.; SOVIERO, V.M. Avaliação do padrão de aleitamento e sucção não nutritiva em um Hospital Amigo da Criança. In: REUNIÃO ANUAL DA SOCIEDADE BRASILEIRA DE PESQUISA ODONTOLÓGICA, 2000, Águas de Lindóia. Anais .... São Paulo: Faculdade de Odontologia da Universidade de São Paulo, 2000. p. 45.

30. FARSI, N.M.A.; SALAMA, F.S; PEDO, C. Sucking habits in Saudi children: prevalence, contributing factors and effects on the primary dentition. Pediatr Dent, v.19, n.1, p.28-33, Jan. 1997.

31. FERREIRA, M.I.D.T.; TOLEDO, O.A. Relação entre tempo de aleitamento materno e hábitos bucais. Rev ABO Nac, v. 5, n.6, p.317-320, oct. /nov. 1997.

32. FINOCCHI, L.L. Breast feeding, bottle feeding and their impact on oral habits - a review of the literature. Dent Hygine, v.56, n.11, p.2125, Nov. 1982.

33. FORTE, F.D.S.; BOSCO, V.L.; GOUVEIA, M.M.A.; SANTOS, L.M.; FREITAS, S.F.T. Influência do aleitamento na instalação de hábitos de sucção não-nutritiva. In: REUNIÃO ANUAL DA SOCIEDADE BRASILEIRA DE PESQUISA ODONTOLÒGICA, 2000, Águas de Lindóia. Anais... São Paulo: Faculdade de Odontologia da Universidade de São Paulo, 2000. p. 136. 
34. FOSTER, T.D.; HAMILTON, M.C. Occlusion in the primary dentition study of children at $21 / 2$ and 3 years of age. Br Dent J, v. 126, n. 2, p.76- 79, Jan. 1969.

35. GIMENEZ, C.M.M; MORAES, A.B.A; AMBROZANO, G., CASTRO, F.M. Prevalência de maloclusões na $1^{a}$ infância e fatores etiológicos correlacionados. In: REUNIÃO ANUAL DA SOCIEDADE BRASILEIRA DE PESQUISA ODONTOLÓGICA, 2000, Águas de Lindóia. Anais. São Paulo: Faculdade de Odontologia da Universidade de São Paulo, 2000. p. 139.

36. GOMES, I.C. D.; PROENÇA, M.G.; LIMONGI, S.C.O. Avaliação e terapia da motricidade oral. In: Temas de fonoaudiologia. 5. ed. São Paulo: Loyola, 1993. p. 59-119.

37. GORELICK, L. On the use of pacifiers in preventing malocclusions. N Y State Dent J, v. 21, n. 1, p. 3-10, Jan. 1955.

38. GUIDELINES for management of the developing dentition in pediatric dentistry. J Pediatr Dent, v. 21, n.5, p. 50-52, 1999/2000. Número especial.

39. HANNUKSELA, A.; VÄÄNÄNEN, A. Predisposing factors for malocclusion in 7-year-old children with special reference to atopic disease. Am J Orthod Dentofac Orthop, v.92, n. 4, p. 299-303, Oct. 1987. 
40. KNOTT, V.B. Longitudinal study of dental arch widths at four stages of dentition. Angle Orthod, v.42, n.4, p.387-394, Oct. 1972.

41. KUIJPERS-JAGTMAN, A.M. Effects of sucking habtis on the dentofacial development. Ned Tijdschr Tandheelkd, v.96, n.6, p. 256-258, June 1989. [Resumo]

42. LARSSON, E. Artificial sucking habits: etiology, prevalence and effect on occlusion. Int J Orofac Myol, v.20, p.10-26, Nov. 1994.

43. LARSSON, E. Dummy-and finger-sucking habits in 4-year-olds. Swed Dent J, v.68, n.6, p. 219-224, 1975.

44. LARSSON, E. Dummy-and finger-sucking habits with special attention to their significance for facial growth and occlusion.1. Incidence study. Swed Dent J, v.64, n.10, p.667-672, Oct. 1971.

45. LARSSON, E. Dummy-and finger-sucking habits with special attention to their significance for facial growth and occlusion. 4. Effect on facial growth and occlusion. Swed Dent J, v.65, n.12, p.605-632, Dec. 1972.

46. LARSSON, E. The effect of dummy-sucking on the occlusion: a review. Eur J Orthod, v.8, n.2, p.127-130, May 1986.

47. LARSSON, E. The prevalence and aetiology of prolonged dummy- and finger-sucking habits. Eur J Orthod, v.7, n.3, p. 172-176, Aug. 1985. 
48. LARSSON, E. Prevalence of crossbite among children with prolonged dummy-and finger-sucking habit. Swed Dent J, v.7, n.3, p.115-119, 1983.

49. LARSSON, E.; DAHLIN, K.G. The influence and the etiology of the initial dummy- and finger-sucking habit. Am J Orthod, v.87, n.5, p.432435, May 1985.

50. LARSSON, E.; ÖGAARD, B.; LINDSTEN, R. Rearing of Swedish, Norwegian, and Norwegian Sami children. Scand J Dent Res, v. 101, n.6, p.382-385, Dec. 1993.

51. LEWIS, S.J. Undesirable habits influencing the deciduous dentition. J Am Dent Assoc, v. 18, n.9, p. 1766-1778, Sept. 1931.

52. LINDNER, A.; HELLSING, E. Cheek and lip pressure against maxillary dental arch during dummy sucking. Eur J Orthod, v. 13, n.5, p.362366, Oct. 1991

53. LINDNER, A.; MODEER, T. Relation between sucking habits and dental characteristics in preschool children with unilateral cross-bite. Scand J Dent Res, v. 97, n.3, p.278-283, June 1989. [Resumo]

54. LINDSTEN, R.; LARSSON, E.; ØGAARD, B. . Dummy-sucking behaviour in 3-year old Norwegian and Swedish children. Eur J Orthod, v.18, n.2, p.205-209, Apr. 1996. 
55. MARCHESAN, I.Q. Motricidade oral - visão clínica do trabalho fonoaudiológico integrado com outras especialidades. São Paulo: Pancast, 1993. 71 p.

56. MARGOLIS, F.S. Ordinary versus orthodontic pacifiers. Dent Survey, v.56, n.7, p.44-45, July 1980 .

57. MARIGO, M.; FRAUCHES, M.B. Hábitos bucais nocivos à oclusão dentária e suas correlações com o fator sócio-econômico. Rev Cient Cenbios, v.1, n.1, p.29-37, jun. 1993.

58. MATHUR, G.P.; MATHUR, S.; KAHNDUJA, G.S. Non-nutritive suckling and use of pacifiers. Indian Pediatr, v.27, n.11, p. 1187-1189, Nov. 1990.

59. MODÉER, T.; ODENRICK, L.; LINDNER, A. Sucking habits and their relation to posterior cross-bite in 4 years-old children. Scand J Dent Res, v. 90, n.4, p.323-328, Aug. 1982.

60. MODESTO, A.; VIEIRA, A.R.; CAMARGO, M.C.F. Avaliação do uso e das características das chupetas utilizadas por crianças do município do Rio de Janeiro. J Bras Odontopediatr Odontol Bebê, v.2, n.10, p.438-441, 1999.

61. MOFFATT, J.B. Habits and their relation to malocclusion. Aust Dent J, v.8, n.2, p.142-149, Apr. 1963. 
62. MONGUILHOTT, L.M.J. Contribuição ao estudo do hábito de sucção em escolares na faixa etária de 5 a 11 anos de idade da zona urbana de Florianópolis, Santa Catarina. Florianópolis, 1986. 80 p. Dissertação (Mestrado em Odontopediatria) - Universidade Federal de Santa Catarina.

63. MOREIRA, M. Desenvolvimento anatomofuncional da boca - da fase pré-natal aos 3 anos de idade. In: CORRÊA, M.S.N.P. Odontopediatria na primeira infância. São Paulo: Santos, 1998. p. $101-115$

64. MOREIRA, M.H.M. Influência de diferentes tipos de aleitamento sobre a relação incisal, tipos de arco (Baume) e prevalência de alguns hábitos. São Paulo, 1978. 64 p. Dissertação (Mestrado em Odontopediatria) - Faculdade de Odontologia da Universidade de São Paulo.

65. MORESCA, C.A.; FERES, M.A. Hábitos viciosos bucais. In: Ortodontia para fonoaudiologia. Eros Petrelli (Coord.). São Paulo: Lovise. 1992, p.163-176.

66. MOYERS, R.E. Orthodontic techniques In: Handbook of orthodontics. 4. ed. Chicago: Year Book, 1988. p.511-560. 
67. MYLLÄRNIEMI, S. Oral and dental state in Helsinki preschool children. III. Prevalence of dummy and finger sucking habits. Proc Finn Dent Soc, v.69, n.2, p. 47-51, 1973.

68. NETER, J., WASSERMAN, W. ; KUTNER, M.H.. Applied Linear Statistical Models. Boston: Irwin. 1996. 1408 p.

69. NORMAN, R.A.V. Digit-sucking: a review of the literature, clinical observations and treatment recommendations. Int J Orofac Myol, v.23, p.14-34, 1997. Número especial.

70. ØGAARD, B.; LARSSON, E.; LINDSTEN, R. The effect of sucking habits, cohort, sex, intercanine arch widths, and breast or bottle fedding on posterior crossbite in Norwegian and Swedish 3-year-old children. Am J Orthod Dentofac Orthop, v.106, n.2, p.161-166, Aug. 1994.

71. OLIVEIRA FERNANDES, H. Etiologia das maloclusões dentárias. Rev Bras Odontol, v. 23, n.129, p.131-137, maio / jun. 1964.

72. PADOVAN, B.A.E. Correlação entre odontologia e fonoaudiologia. J Bras Ortod e Ortop Maxilar, v.1,n.2, p.73-76, mar./abr. 1996.

73. PADOVAN, B.A.E. Reorganização neurofuncional - método Padovan. J Bras Ortod e Ortop Maxilar, v. 2, n.10, p. 3-11, jul./ago. 1997.

74. PARFITT, G.J. Conditions influencing the incidence of occlusal and interstitial caries in children. J Den Child, v. 23, n.1, p. 31-39, 1956. 
75. PATRÍCIO, S.F. Estudo da correlação entre mordida aberta anterior e a relação terminal dos segundos molares decíduos (plano vertical, degrau mesial e degrau distal para a mandíbula), em crianças da cidade de João Pessoa, na faixa etária de 25 a 61 meses. Camarajibe, 1993. 80p. Tese (Doutorado em Odontopediatria) - Faculdade de Odontologia de Pernambuco da Fundação Universidade de Pernambuco.

76. PAUNIO, P.; RAUTAVA, P.; SILLANPÄÄ, M. The finnish family competence study: the effects of living conditions on suking habits in 3-years-old Finnish children and the association between these habits and dental occlusion. Acta Odontol Scand, v.51, n.1, p.2329, Feb. 1993.

77. PETERS, C.F.; GAVAZZI, J.C.C.; OLIVEIRA, SLF. Estudo da prevalência de mordidas cruzadas na dentadura decídua - relação com hábitos de sucção. Rev Paul Odontol, v. 8, n.2, p.38-43, mar./abr. 1986.

78. POPOVICH, F. The prevalence of sucking habit and its relationship to malocclusion. Oral Health, v.57, n.7, p.498-505, July 1967.

79. PROFITT, W.R. On the aetiology of malocclusion. Br J Orthod, v.13, n. 1, p.1-11, Jan. 1986. 
80. RAVN, J.J. Sucking habtis and occlusion in 3-year-old children. Scan J Dent Res, v. 84, n.4, p.204-209, July 1976.

81. RAVN, J.J. The prevalence of dummy and finger sucking habits in Copenhagen children until de age of 3 years. Community Dent Oral Epidemiol, v.2, n.6, p. 316-322, Summer 1974.

82. ROBLES, F.R.P.; MENDES, F.M.; HADDAD, A.E.; CORRÊA, M.S.N.P. A influência do período de amamentação nos hábitos de sucção persistentes e a ocorrência de maloclusões em crianças com dentição decídua completa. Rev Paul Odontol, v.21, n.3, p. 4-9, maio/jun. 1999.

83. RUTRICK, R.E. Crossbite correction with a therapeutic pacifier. J Dent Child, v.41, n.6, p.442-444, Nov./Dez. 1974.

84. SCHWARTZ, C. ; SCHWARTZ, B. Discutindo a etiopatogenia da máoclusão. In: Ortodontia para fonoaudiologia. Eros Petrelli (Coord.). São Paulo: Lovise. 1992. p. 97-109.

85. SERRA-NEGRA, J.M.C.; PORDEUS, I.A.; HORTA, P.; OKANO, S.; FERREIRA, S.C.V. O uso de chupeta por crianças- relato de mães. J Bras Odontopediatr Odontol Bebê, v. 2, n.7, p. 211-217, 1999.

86. SERRA-NEGRA, J.M.C.; PORDEUS, I.A.; ROCHA Jr., J.F. Estudo da associação entre aleitamento, hábitos bucais e maloclusões. Rev Odontol Univ São Paulo, v.11, n.2, p.79-86, abr./jun. 1997. 
87. SIES, M.L.; CARVALHO, M.P. Uma visão fonoaudiológica em Odontopediatria na primeira infância. In: CORRÊA, M.S.N.P. Odontologia na primeira infância. São Paulo: Santos. 1998. p.39-53.

88. SILVA FILHO, O.G.; FREITAS, S.F.; CAVASSAN, A.O. Hábitos de sucção - elementos passíveis de intervenção. Estomatol Cult, v. 16, n.4, p.61-71, out./dez. 1986.

89. SILVA FILHO, O. G.; GONÇALVES, R.M.G.; MAIA, F.A. Sucking habits: clinical management in dentistry. J Clin Pediatr Dent, v.15, n.3, p137-156, 1991.

90. SIM, J.M.; FINN, S.B. Oral habits in children. In: FINN, S.B. Clinical pedodontics. 4. ed. Phildelphia: W.B. Saunders Comapany, 1973. p.370-385

91. SOARES, C.A.S.; TOTTI, J.I.S. Hábitos deletérios e suas conseqüências. Rev CROMG, v. 2,n.1, p. 21-26, jan./jun. 1996.

92. SOVIERO, V.M.; BASTOS,E.; MASSAO, J.M.; VIANNA, R. Contribuição ao estudo do relacionamento ântero-posterior entre as arcadas em crianças brasileiras de 2 a 6 anos de idade. São Paulo: IMC - Image Maker e Comunicações, 1997. p. 52. [Livro Anual do Grupo Brasileiro de Professores de Ortodontia e Odontopediatria, v. 6]. 
93. TOMASI, E.; VICTORIA, C.G.; OLINTO, M.T.A. Padrões e determinantes do uso de chupeta em crianças. J Pediatr, v. 70, n.3, p.167-173, 1994.

94. TOMITA, E. N.; BIJELLA, V.T.; FRANCO, L.J. Relação entre hábitos bucais e má oclusão em pré-escolares. Rev Saúde Pública, v. 34, n. 3, p.299-303, Jun. 2000.

95. TURGEON-O’BRIEN, H.; LACHAPELLE, C.; GANGON, P.F.; LAROCQUE, I.; MAHUE-ROBERT, L.-F. Nutritive and non-nutritive sucking habits: a review. J Dent Child, v.63, n.5, p.321-327, Sept./Oct. 1996.

96. USBERTI, A.C.; PETERS,C.F.; ISSAO, M. Alterações dimensionais do arco dentário decíduo. Rev Fac Odontol São Paulo, v. 23, n.1, p.73-80, jan./jun. 1985.

97. VADIAKAS, G.; OULIS,C.; BERDOUSES, E. Profile of non-nutritive sucking habits in relation to nursing behavior in pre-school children. J Clin Pediatr Dent, v.22, n.2, p. 133-136, Winter 1998.

98. VALENTE, A.; MUSSOLINO, Z.M. Freqüência de sobressaliência, sobremordida e mordida aberta anterior na dentição decídua. Rev Odonto USP, v. 3, n.3, p. 402-407, jul./set. 1989.

99. WEBTER'S ninth new collegiate dictionary. Spingfield: Merriam-Webter, 1983. 1562 p. 
100. ZADIK, D.; STERN, N.; LITNER, M. Thumb-and pacifier-sucking habits. Am J Orthod, v. 71, n.2, p. 197-201, Feb. 1977. 


\section{SUMMARY}

\section{EVALUATION OF THE DENTAL ARCHES AND MYOFUNCTIONAL ORAL STRUCTURES IN CHILDREN WITH COMPLETE PRIMARY DENTITION, ACCORDING TO PACIFIER USE AND TYPE}

This study evaluated through clinical examination the characteristics of the dental arches and myofunctional oral structures of 61 children aged 36- to-60-months, who either had pacifier-sucking habit or did not. Pacifier use and type was compared to family income and mother's attitudes and educational level. This was assessed by a questionnaire distributed to the mothers. The children were divided into three groups: 1. those who never had pacifier sucking habit, 2. those who only used anatomic or orthodontic pacifier, and 3. those who only used conventional pacifier. No statistically significant relationship was found between pacifier use and the family income, mother's educational level, and child's sex and number of siblings. The children who were breastfed for a smaller period of time and had one or more pacifiers on his/her layette had higher prevalence of pacifier sucking habit. No statistical significant relationship was found between arch type (Type I or Type II according to Baume's classification), 
terminal plane relationship of second primary molars, medline and primate spaces among the three groups studied. Class II primary canine relationship was significantly greater among pacifier users than among those without this sucking habits. It was observed that both, the anatomic (orthodontic) and conventional pacifiers lead to anterior open bite and posterior crossbite. No significant difference was found between the ones who used the anatomic (orthodontic) pacifier or the conventional one, in respect to the mean openbite $(p=0,344)$. Compared to children without sucking habit, children with pacifier habit had a greater mean overjet (in milimeters) $(p=0,000)$. Posterior crossbite was statistically different among the children who used the conventional pacifier when compared to the other two groups $(p=0,010)$. The upper intercanine distance was significantly smaller among those who had pacifier sucking-habit when compared to those habit-free, but no significant difference was found among the three groups with respect to the lower intercanine distance. Among the myofunctional oral structures evaluated, the ones that demonstrated statistical difference among the three groups were the cheek mobility $(p=0,022)$ and the hard palate shape $(p=0,022)$; being that the group of children who never sucked a pacifier, showed a higher prevalence of normality of these two structures than the ones who had a pacifier sucking habit. In regards to how frequent the child sucked the pacifier throughout the day, it was seen that those who "always sucked" had a significantly greater overjet $(p=0,021)$, than those who "suck sometimes" or "just held" the pacifier in the mouth. 
APÊNDICE A QUESTIONÁRIO

Unidade:

Ficha número:

IDENTIFICAÇÃO

Nome criança:

sexo:

Nome mãe ou responsável:

Endereço:

Bairro:

CEP: outro

Cidade

Telefone:

Data nascimento: Idade:

1. Qual é a renda familiar em números de salários mínimos?
a. 1 até quase 3 salários mínimos
b. 3 a quase 5 salários mínimos
c. 5 a quase 7 salários mínimos
d. mais que 7 salários mínimos

2. A mãe da criança estudou até que ano?:
a. não estudou
b. primeiro grau
d. superior
e. pós-graduação
c. segundo grau

3. A criança tem irmãos $(a, 0)$ ?
a. filho único
b. 1-2 irmãos
c. 3 ou mais

4. Quando começou o aleitamento materno exclusivo? Quando você começou a dar a peito ?:

5. Até quando você deu somente peito, sem água, chás, leite em pó ou sucos? (aleitamento materno exclusivo) meses

6. Até quando você deu o peito?

7. Com quantos meses foi introduzida a mamadeira?

8. A criança continua utilizando a mamadeira?
a. $\operatorname{sim}$
b. não

9. Com quantos meses ou anos a criança parou de usar mamadeira? 
10. Qual é o material do bico da mamadeira que a criança usa ou usou?:
a. silicone (transparente)
b. borracha (amarelo)

11. Qual é o formato do bico da mamadeira que a criança usa ou usou ?:

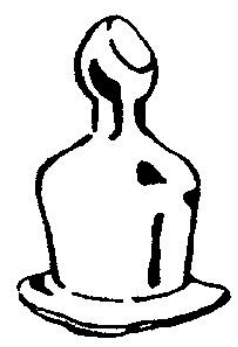

a

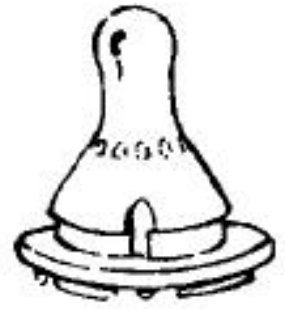

b.

12. Qual é a marca do bico da mamadeira que a criança usa ou usou?

13. A criança chupa dedo agora?
a. $\operatorname{sim}$
b. não

14. Ela já chupou dedo?
a. sim , quando parou?
b. não

15. Você acha que o uso inadequado, errado, e/ ou prolongado da chupeta pode provocar algum dano na dentição e desenvolvimento do seu filho (a)?
a. $\operatorname{sim}$
b. não

16. Com quantos meses a criança iniciou uso da chupeta?

17. Quem iniciou o hábito da chupeta na criança ? Quem deu a chupeta pela primeira vez para a criança?
a. mãe
b. pai
c. pai e mãe
d. avós
e. babá
f. outro, quem?:

18. Onde a criança usa chupeta agora?
a. na creche, escola
b. só em casa
c. creche, escola e casa 
19. Em que momentos do dia a criança usa a chupeta?:
a. só para dormir:
b. antes de dormir:
c. o dia inteiro:
d. outro:

20. Quantas horas por dia a criança usa chupeta agora?

21. Como é o hábito de sucção da chupeta?
a. fica sugando sempre
b. suga as vezes
c. só apoia na boca

22. Você relaciona o uso da chupeta pelo seu filho (a) com algum destes fatores?:
a. depois da amamentação
b. fome
c. hora de dormir
d. tensão, irritação, nervosismo da criança
e. não relacionou
f. outro

\section{Por que o uso da chupeta iniciou?}

a. é normal a criança chupar chupeta

b. sempre dei para meu(s) outro (s) filho(s)

c. para trocar o hábito de chupar o dedo

d. necessidade de sucção (criança sugava lábio e dedo), orientação de algum profissional

e. tranquilizar criança quando chorava

f. nascimento de irmão/irmão

g. separação dos pais

h. período de grande tensão em casa 
24. Qual o tipo do escudo da chupeta (onde a flecha está apontando)?:

a.

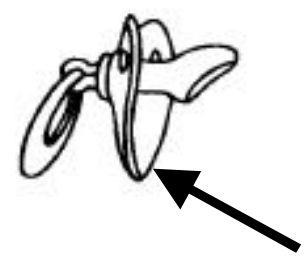

b.

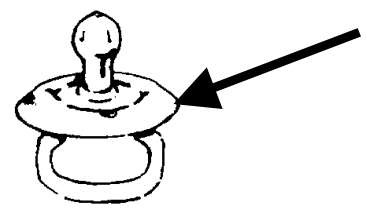

c.

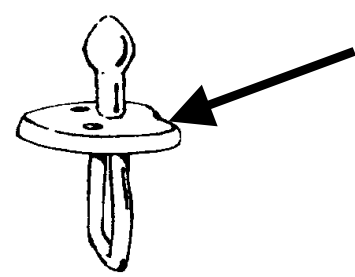

25. Qual é o tipo de bico da chupeta (onde a seta está apontando)?

a.

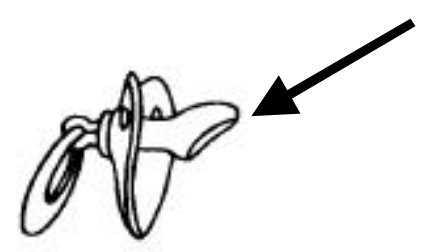

b.

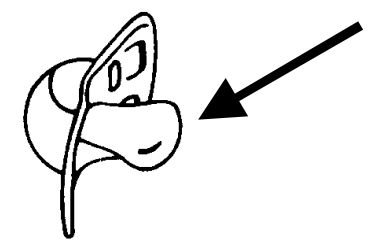

c.

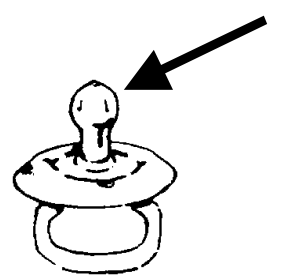

26. Qual é a marca da chupeta que a criança usa?

27. Qual é o material da chupeta que a criança usa?
a. silicone (transparente)
b. borracha, látex (amarelo)

28. A criança fica com mais de uma chupeta ao mesmo tempo?
a. $\operatorname{sim}$
b. não

29. Chupeta fica amarrada ou presa à roupa da criança?
a. $\operatorname{sim}$
b. não

30. Quantas chupetas faziam parte do enxoval da criança ?
a. nenhuma
b. 1- 2
c. mais que duas

31. Você fez algum curso para gestante ou pré-natal?
a. $\operatorname{sim}$
b. não 
32. Caso você tenha feito, foi orientada quando ao uso da chupeta?
a. $\operatorname{sim}$
b. não

33. Você foi orientada quanto ao uso da mamadeira ?
a. $\operatorname{sim}$
b. não

34. Você levou as chupetas à Maternidade?
a. $\operatorname{sim}$
b. não

35. Usou as chupetas na Maternidade?
a. $\operatorname{sim}$
b. não 
APÊNDICE B QUESTIONÁRIO

Unidade:

Ficha número:

IDENTIFICAÇÃO

Nome criança:

sexo:

Nome mãe ou responsável:

Endereço:

Bairro:

CEP: outro

Cidade

Telefone:

Data nascimento: Idade:

1. Qual é a renda familiar em números de salários mínimos?
a. 1 até quase 3 salários mínimos
b. 3 a quase 5 salários mínimos
c. 5 a quase 7 salários mínimos
d. mais que 7 salários mínimos

2. A mãe da criança estudou até que ano?:
a. não estudou
b. primeiro grau
d. superior
e. pós-graduação
c. segundo grau

3. A criança tem irmãos $(a, 0)$ ?
a. filho único
b. 1-2 irmãos
c. 3 ou mais

4. Quando começou o aleitamento materno exclusivo? Quando você começou a dar a peito ?:

5. Até quando você deu somente peito, sem água, chás, leite em pó ou sucos? (aleitamento materno exclusivo) meses

6. Até quando você deu o peito?

7. Com quantos meses foi introduzida a mamadeira?

8. A criança continua utilizando a mamadeira?
a. $\operatorname{sim}$
b. não

9. Com quantos meses ou anos a criança parou de usar mamadeira? 
10. Qual é o material do bico da mamadeira que a criança usa ou usou?:
a. silicone (transparente)
b. borracha (amarelo)

11. Qual é o formato do bico da mamadeira que a criança usa ou usou ?:

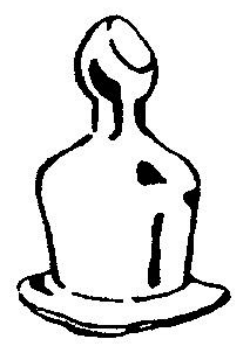

a

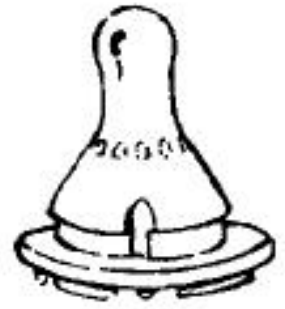

b.

12. Qual é a marca do bico da mamadeira que a criança usa ou usou?

13. A criança chupa dedo agora?
a. $\operatorname{sim}$
b. não

14. Ela já chupou dedo?
a. sim , quando parou?
b. não

15. Você acha que o uso inadequado, errado, e/ ou prolongado da chupeta pode provocar algum dano na dentição e desenvolvimento do seu filho (a)?
a. $\operatorname{sim}$
b. não

16. Com quantos meses a criança iniciou uso da chupeta?

17. Quem iniciou o hábito da chupeta na criança ? Quem deu a chupeta pela primeira vez para a criança?
a. mãe
b. pai
c. pai e mãe
d. avós
e. babá
f. outro, quem?:

18. Onde a criança usa chupeta agora?
a. na creche, escola
b. só em casa
c. creche, escola e casa 
19. Em que momentos do dia a criança usa a chupeta?:
a. só para dormir:
b. antes de dormir:
c. o dia inteiro:
d. outro:

20. Quantas horas por dia a criança usa chupeta agora?

21. Como é o hábito de sucção da chupeta?
a. fica sugando sempre
b. suga as vezes
c. só apoia na boca

22. Você relaciona o uso da chupeta pelo seu filho (a) com algum destes fatores?:
a. depois da amamentação
b. fome
c. hora de dormir
d. tensão, irritação, nervosismo da criança
e. não relacionou
f. outro

\section{Por que o uso da chupeta iniciou?}

a. é normal a criança chupar chupeta

b. sempre dei para meu(s) outro (s) filho(s)

c. para trocar o hábito de chupar o dedo

d. necessidade de sucção (criança sugava lábio e dedo), orientação de algum profissional

e. tranquilizar criança quando chorava

f. nascimento de irmão/irmão

g. separação dos pais

h. período de grande tensão em casa 
24. Qual o tipo do escudo da chupeta (onde a flecha está apontando)?:

a.

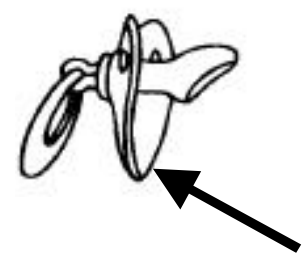

b.

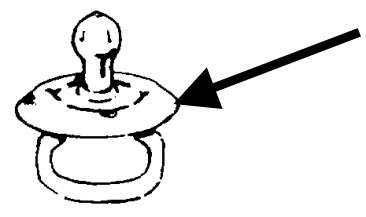

c.

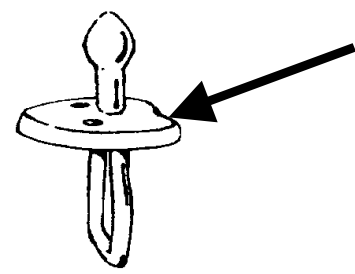

25. Qual é o tipo de bico da chupeta (onde a seta está apontando)?

a.

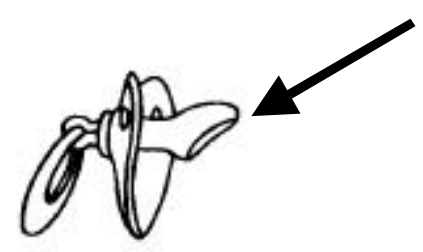

b.

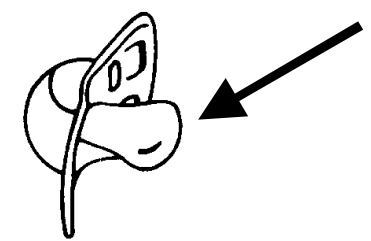

c.

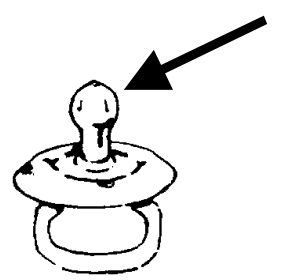

26. Qual é a marca da chupeta que a criança usa?

27. Qual é o material da chupeta que a criança usa?
a. silicone (transparente)
b. borracha, látex (amarelo)

28. A criança fica com mais de uma chupeta ao mesmo tempo?
a. $\operatorname{sim}$
b. não

29. Chupeta fica amarrada ou presa à roupa da criança?
a. $\operatorname{sim}$
b. não

30. Quantas chupetas faziam parte do enxoval da criança ?
a. nenhuma
b. 1- 2
c. mais que duas

31. Você fez algum curso para gestante ou pré-natal?
a. $\operatorname{sim}$
b. não 
32. Caso você tenha feito, foi orientada quando ao uso da chupeta?
a. $\operatorname{sim}$
b. não

33. Você foi orientada quanto ao uso da mamadeira ?
a. $\operatorname{sim}$
b. não

34. Você levou as chupetas à Maternidade?
a. $\operatorname{sim}$
b. não

35. Usou as chupetas na Maternidade?
a. $\operatorname{sim}$
b. não 
APÊNDICE C

AVALIAÇÃO DAS ESTRUTURAS MIOFUNCIONAIS ORAIS

Ficha número:

Data:

Nome da criança:

Sala:

Unidade:

Idade:

\section{LÁBIOS:}

Aspecto:

normal

ocluídos com tensão

entreabertos

vermelhão aparente

Tonicidade:

hipotonocidade superior hipertonocidade superior inferior

ambos

ambos

Mobilidade:

bico-sorriso ocluídos sopro (saliva/quantidade)

bico-sorriso abertos vibração

beijo

\section{LÍNGUA:}

Aspecto:

normal sulcada

Tonicidade:

normal hipotônicidade

Mobilidade:

dentro fora

lateralização (externa/interna)

cima

baixo

alargamento

afilamento

\section{BOCHECHAS:}

Tonicidade:

normal

Mobilidade:

inflar suflar

\section{PALATO DURO:}

normal

estreito

alto

estreito e alto

\section{SIMETRIA FACIAL}

normal 